\title{
Nanostructured Graphene Oxide-Based Hybrids as Anodes for Lithium-Ion Batteries
}

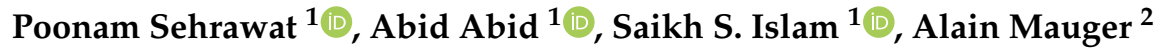 \\ and Christian M. Julien $2, *$ (D) \\ 1 Centre for Nanoscience and Nanotechnology, Jamia Millia Islamia (A Central University), \\ New Delhi 110025, India; sehrawatpoonam@gmail.com (P.S.); abid.zak@gmail.com (A.A.); \\ sislam@jmi.ac.in (S.S.I.) \\ 2 Institut de Minéralogie, de Physique des Matériaux et de Cosmochimie (IMPMC), Sorbonne Université, \\ CNRS-UMR 7590, 4 Place Jussieu, CEDEX 05, 75252 Paris, France; alain.mauger@sorbonne-universite.fr \\ * Correspondence: christian.julien@sorbonne-universite.fr
}

Received: 28 November 2020; Accepted: 14 December 2020; Published: 16 December 2020

\begin{abstract}
Presently, the negative electrodes of lithium-ion batteries (LIBs) are constituted by carbon-based materials, which exhibit a limited specific capacity $372 \mathrm{mAh} \mathrm{g}^{-1}$ associated with the cycle in the composition between $\mathrm{C}$ and $\mathrm{LiC}_{6}$. Therefore, many efforts are currently made towards the technological development of nanostructured graphene materials because of their extraordinary mechanical, electrical, and electrochemical properties. Recent progress on advanced hybrids based on graphene oxide (GO) and reduced graphene oxide (rGO) has demonstrated the synergistic effects between graphene and an electroactive material (silicon, germanium, metal oxides $\left(M \mathrm{O}_{\mathrm{x}}\right)$ ) as electrode for electrochemical devices. In this review, attention is focused on advanced materials based on GO and rGO and their composites used as anode materials for lithium-ion batteries.
\end{abstract}

Keywords: carbonaceous materials; graphene oxide; reduced graphene oxide; composite anodes; lithium-ion batteries; supercapacitors

\section{Introduction}

Recently, researchers' quest for advanced devices for storing and converting sustainable energy is increasing day by day due to the demand for renewable and clean energy resources. Among all power sources, lithium-ion batteries (LIBs), sodium-ion batteries (SIBs), and electrochemical supercapacitors (ESCs) have become the most important and efficient devices for storing the electricity produced from solar cells and windmills, and they are currently in use to solve the problem of intermittency of these renewable energy sources for their integration in grid-scale stationary storage [1,2]. Anode materials for rechargeable batteries can be classified in three main groups depending on the mechanism of lithiation [3-9]:

(i) Alloying materials such as $\mathrm{Si}, \mathrm{Ge}, \mathrm{Sn}, \mathrm{Al}, \mathrm{Bi}$, etc.,

(ii) Conversion materials like transition-metal oxides $\left(\mathrm{Mn}_{\mathrm{x}} \mathrm{O}_{\mathrm{y}}, \mathrm{NiO}, \mathrm{Fe}_{\mathrm{x}} \mathrm{O}_{\mathrm{y}}, \mathrm{CuO}, \mathrm{Cu}_{2} \mathrm{O}, \mathrm{MoO}_{2}\right.$, etc.), metal sulfides, metal phosphides, and metal nitrides $\left(M_{x} X_{y}\right.$; here $\left.X=S, P, N\right)$,

(iii) Insertion materials, such as carbonaceous compounds (graphite, porous carbon, carbon nanotubes, graphene), $\mathrm{TiO}_{2}, \mathrm{Li}_{4} \mathrm{Ti}_{5} \mathrm{O}_{12}$, etc.

Presently, the negative electrodes of lithium-ion batteries (LIBs) are constituted by graphite-based materials, which exhibit a limited specific capacity of $372 \mathrm{mAh} \mathrm{g}^{-1}$ associated with the cycle in the composition between $\mathrm{C}$ and $\mathrm{LiC}_{6}$. As promising anode materials for LIBs, silicon and transition-metal oxides have many advantages over graphite currently in use, such as very high capacity, wide 
availability, good stability, and environmental friendliness. However, certain obstacles prevent the use of these materials, namely low electronic/ionic conductivity, large volume variations, poor cycling performance, and low faradaic efficiency in the first cycle. To solve these issues, many strategies have been proposed such as the fabrication of composite electrode including a carbon-type compound like graphene and its derivatives [10,11].

Since the first experimental investigation in 2004, mono-layer graphite, known as graphene [12], has attracted considerable interest to replace graphite due to its outstanding properties. Graphene has an exceptional chemical architecture, i.e., a two-dimensional (2D) monolayer $s p^{2}$ hybridized conjugated carbon atoms with a tight packing of honeycomb lattice and displays remarkable electronic, thermal, optical, and mechanical properties [13]. It is a material that has attained tremendous attention due to its large surface area of $2630 \mathrm{~m}^{2} \mathrm{~g}^{-1}$, giant electrical conductivity of $6000 \mathrm{~S} \mathrm{~cm}^{-1}$, and high tensile strength of $130 \mathrm{GPa}$ [14]. A large number of materials have been combined with graphene, i.e., metals, semiconductors, metal oxides, polymers, alloys, etc., and applied in energy storage devices, such as lithium-based batteries, especially lithium-ion (LIBs), lithium sulfur (Li-S), and lithium-air $\left(\mathrm{Li}-\mathrm{O}_{2}\right)$ (for a review, see Ref. [15]). However, the 2D-sheets of graphene tend restacking and irreversible aggregation due to the strong $\mathrm{p}-\mathrm{p}$ interaction, hydrophobic interaction, and van der Waals force, which induce small specific surface area and poor electrochemical performance (i.e., low Li-ion diffusion rate) [16]. These issues can be overcome by the elaboration of graphene oxide (GO) and reduced graphene oxide (rGO).

Why use reduced graphene oxide in batteries instead of just graphene? Graphene is hydrophobic and difficult to handle in chemical processes, while graphene oxide has superior hydrophylic behavior; thus, graphene oxide is easy to deposit on any surface with any methods. Due to the simple and fast reduction of GO (which results in an increase of the conductivity desirable in batteries), this suggests the possibility of producing low-cost graphene battery by using cost effective rGO. Moreover, rGO can be easily fabricated in terms of mass production [17].

Therefore, using GO or rGO, many efforts are currently being made towards the technological development of new nanostructured hybrid anode materials for LIBs, which exhibit better cycling stability than graphite. We guide the reader to older review papers on graphene-based hybrids as anode materials for prior works $[11,18,19]$. For a historical overview related to GO and rGO synthesis and their electrochemical applications, see Refs. [20,21].

Transition-metal oxides $\left(M \mathrm{O}_{\mathrm{x}}\right)$ have been widely studied as elements of composite electrode due to their different oxidation states and heterogeneous electrochemical activity. The combination of a nanostructured $M \mathrm{O}_{\mathrm{x}}$ with a graphene network has met the ever-growing requirements for energy storage applications. In such hybrids, the graphene component plays several roles including stabilization of nanosized particles, inhibition of the unwanted volumetric changes, increase of the electrical conductivity and enhancement of the mechanical strength, both are improving cyclability and rate capability. Anode hybrids have been extensively investigated including various $\mathrm{MO}_{\mathrm{x}}$ such as $\mathrm{MnO}$ [22], $\mathrm{Mn}_{3} \mathrm{O}_{4}$ [23], $\mathrm{SnO}_{2}$ [24,25], $\mathrm{MoO}_{2}$ [26], $\mathrm{Co}_{3} \mathrm{O}_{4}$ [27], $\mathrm{Fe}_{3} \mathrm{O}_{4}$ [28], and $\mathrm{Fe}_{2} \mathrm{O}_{3}$ [29]. Single elements embedded in carbonaceous matrix have been also actively investigated such silicon [30], germanium [31,32], and tin [33]. For the works related to graphene/metal oxide composites before 2012, we just guide the reader to the review article by Wu et al. [34]. The synthesis of graphene-transition metal oxide hybrid nanoparticles and their application in various fields have been reviewed in 2017 by Jana et al. [35].

In this review, we present the recent five-year developments of graphene-supported nanocomposites for advanced energy storage devices. The electrochemical performances of several rGO-based composites are discussed in relation with their methods of preparation and morphology. Graphene-supported materials are used not only as components of electrodes for batteries, but also for supercapacitors as well. However, recent reviews have been already devoted to such electrodes for supercapacitors [36,37], so that attention in the present work is focused on anode materials for lithium-ion batteries. The paper is organized as follows. A brief introduction to graphene oxide materials is given in Section 2. In Section 3, 
we examine the synthesis and properties of composites of graphene oxide and reduced graphene oxide with a single element, such as silicon, germanium, or tin, the technology of which is currently developed to increase the delivered specific energy, the rate capability, and the cycle life. Similar issues are treated in Section 4 for composites with metal oxides. For each system, we highlight the synthesis, morphology (particle size, porosity, specific surface area), and electrochemical parameters (initial capacity, initial coulombic efficiency (ICE), long-term cycling, and rate capability).

\section{Graphene Oxide Materials}

\subsection{Properties of Graphene Oxides}

Graphite oxide is derived from graphite by introducing a range of oxygen-containing functional groups including carboxylic acid, phenol, hydroxyl, and epoxide [38]. These functional groups attach themselves to carbon atoms in basal planes resulting in widening of the interlayer spacing. This material with an ideal chemical formula of $\mathrm{C}_{8} \mathrm{O}_{2}(\mathrm{OH})_{2}$ has been investigated since the 1850s by the English chemist Brodie [39]. It is an insulator with a large portion of $s p^{3}$ hybridized carbon atoms, which results in a sheet resistance of $\sim 10^{12} \mathrm{~W} \mathrm{sq}^{-1}$ [40] depending on the oxygen content. GO is generally prepared from natural graphite via a modified Hummers' method [41]. The entire process is achieved within a few hours at temperature $T<45^{\circ} \mathrm{C}$. Typically, $100 \mathrm{gr}$ powdered flake graphite and $50 \mathrm{~g} \mathrm{NaNO}$ into $2.3 \mathrm{~L} \mathrm{H}_{2} \mathrm{SO}_{4}$ are mixed at $0{ }^{\circ} \mathrm{C}$ in an ice-bath to form a suspension and then vigorously agitated with $300 \mathrm{~g} \mathrm{KMnO}_{4}$. The exothermic reaction was controlled to prevent the suspension temperature lower than $20^{\circ} \mathrm{C}$. Then, the obtained brownish grey paste is diluted in water and treated with $3 \%$ hydrogen peroxide to reduce the residual $\mathrm{KMnO}_{4}$. Finally, the yellowish-brown cake is washed in warm water and the dry from of GO is obtained by centrifugation and dehydration at $40{ }^{\circ} \mathrm{C}$.

Reduced graphene oxide (rGO) is a layered, two-dimensional sheet of $s p^{2}$-hybridized carbon with ultrahigh specific surface area and excellent electrical conductivity [42,43]. In contrast to GO, rGO transforms into semiconductor or even into graphene-like semimetal [20]. The conductivity of rGO can reach $\sim 10^{3} \mathrm{~S} \mathrm{~m}^{-1}$ [44]. Rao et al. [45] investigated the effect of reducing agents on the electrical resistivity: The average resistivity for GO samples treated with hydroiodic acid appear to be in the range of $0.003-0.022 \Omega \cdot \mathrm{cm}$, followed by those treated with hydrobromic acid $(0.056-0.347 \Omega \cdot \mathrm{cm})$, and finally with hydrochloric acid $(0.33-0.641 \Omega \cdot \mathrm{cm})$. Wang et al. [46] found that the conductivity of rGO could be tuned in the range $2-15 \mathrm{~S} \mathrm{~m}^{-1}$ by changing the synthesis alkaline solution $(8 \leq \mathrm{pH} \leq 14)$. Tokarczyk et al. [47] reported that rGO samples reduced by combined thermal and pressure treatment exhibit values of surface resistivity of $1-128 \mathrm{~W} \mathrm{sq}^{-1}$. Marquez et al. [48] measured the sheet resistance of $226 \mathrm{~W} \mathrm{sq}^{-1}$ for rGO prepared by laser-assisted photothermal reduction process. The properties of rGO depend on the electronic band gap, which depends on the $s p^{2}$ cluster size. They are controlled by performing reversible functionalization of $\mathrm{rGO}$ with oxygen species. The reversible functionalization of rGO results in its partial transformation to GO such that the size of $s p^{2}$ clusters within $s p^{3}$ matrix varies, thereby affecting the $\pi-\pi$ band structure [49].

Three-dimensional (3D) rGO can be easily synthesized by chemical reduction of GO by using reducing agents such as hydrazine hydrate [50,51], sodium borohydride [52], ethylene glycol [53], ascorbic acid [54], and metal powders [55], which endows them with unique properties. rGO was also prepared by reduction of GO using mild green agents, i.e., extract of fruits or vegetables containing plant polyphenols [56]. During the reduction reaction, the structure of graphene (p-conjugated structure) is substantially restored by eliminating oxygen-containing groups in GO. Birch's reaction, which entails the use of ammonia, alkali metal, and an alcohol is another efficient method to reduce GO [57]. As compared with pure graphene, many advantages endow graphene oxide (GO) and reduced graphene oxide ( $\mathrm{rGO}$ ) as a preferred conductive agent in LIBs, such as lower cost, facile preparation processes, large-scale production, and easy functionalization [58-60]. The 2D-layered structures of GO and rGO sheets anchored with metal oxide nanoparticles (NPs) are used to facilitate the electron transport and $\mathrm{Li}^{+}$diffusion in negative electrodes of LIBs [61,62]. rGO proved to be a 
highly versatile conductive and structure stabilizing additive in many hybrids used in LIBs. It is believed that rGO plays an essential role to enhance the electrochemical performance of composite electrodes by serving as the electrical conductive medium for the electron transfer process, providing a synergistic effect between active particles, alleviating the agglomeration of dispersed nanocrystals during the lithiation/delithiation process, and facilitating the reaction by generating well-mixed $\mathrm{Li}_{2} \mathrm{~S}$ in rGO matrix $[3,9,23,63,64]$. In addition, in the particular case of lithium-sulfur batteries, which will not be considered in this review, it facilitates the reaction by generating well-mixed $\mathrm{Li}_{2} \mathrm{~S}$ in $\mathrm{rGO}$ matrix [65].

In September 2020, the price of GO in the form of aqueous acidic paste (C/O atomic ratio 2.5-2.6) is 1600 US\$ per $\mathrm{kg}$, while $50 \mathrm{~g}$ of rGO (fully reduced) in a volume of 4-5 L costs 1200 US\$ [66].

To evidence the reduction of GO to rGO, the as-synthesized samples are currently characterized by thermogravimetry analysis (TGA), X-ray diffraction (XRD), and Raman spectroscopy. Figure 1a displays the TGA profiles of GO prepared via the Hummers' method and rGO obtained by hydrothermal process. The initial weight loss of GO from $100{ }^{\circ} \mathrm{C}$ to $200{ }^{\circ} \mathrm{C}$ was attributed to the decomposition of residual oxygen-containing functional groups. On another hand, the rGO phase is stable up to $350{ }^{\circ} \mathrm{C}$, which indicates that the main oxygenated functional groups were removed from the network by the reduction process during the synthesis. Above $200{ }^{\circ} \mathrm{C}$, the loss results from the decomposition of carboxyl, hydroxyl, and epoxy groups at the edge and basal planes. Figure $1 \mathrm{~b}$ presents the typical XRD patterns, in which the reflections from the stacked atomic planes of GO and rGO appear at the $2 \theta$ angle of $\sim 12.5^{\circ}$ and $24.0^{\circ}$, respectively, corresponding to the interlayer spacing of $7.08 \AA$ for GO and $3.71 \AA$ for rGO. Figure 1c shows the typical Raman spectra of GO and rGO samples, showing characteristic D band (at ca. $1348 \mathrm{~cm}^{-1}$ ) and $\mathrm{G}$ band (at ca. $1588 \mathrm{~cm}^{-1}$ ). The peak intensity ratio $I_{\mathrm{D}} / I_{\mathrm{G}}$ increases upon reduction, which reveals the removal of oxygenated functional groups attached on carbon backbones. The $I_{\mathrm{D}} / I_{\mathrm{G}}$ ratio in Raman spectroscopy can be used to evaluate the distance between defects in graphene, which is about 1 for pristine graphene and increases with the decrease in average size of the $s p^{2}$ domain and average crystalline size $\left(L_{\mathrm{a}}\right): L_{\mathrm{a}}=\left(2.4 \times 10^{-10}\right) \lambda^{4}\left(I_{\mathrm{D}} / I_{\mathrm{G}}\right)^{-1}$, where $\lambda$ is the laser wavelength in $\mathrm{nm}[67,68]$. In the present case, the calculated average crystalline sizes of GO and RGO are 22 and 13 nm, respectively, indicating the decrease in average crystalline size of RGO compared with GO.
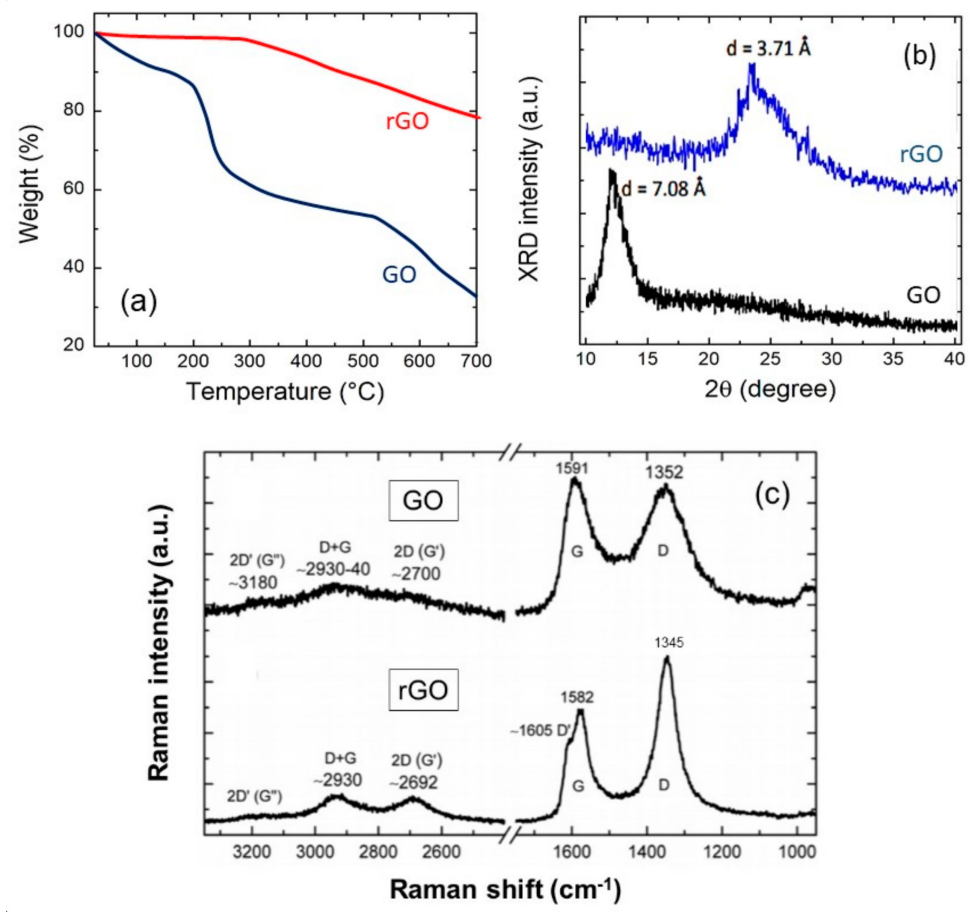

Figure 1. Characterization of graphene oxide (GO) prepared via the Hummers' method and reduced graphene oxide (rGO) obtained by hydrothermal process by (a) thermogravimetry analysis, (b) X-ray diffraction, and (c) Raman spectroscopy. 


\subsection{Lithiation of $r G O$}

The lithiation mechanism and lithium storage capacity of rGO have been the subject of numerous investigations by means of first-principle calculations and by experimental studies such as galvanostatic charge/discharge (GCD) measurements, cyclic voltammetry (CV), and differential capacity curves [69-77]. The theoretical capacity of graphene is $744 \mathrm{mAh} \mathrm{g}^{-1}$ if $\mathrm{Li}$ can be absorbed on both sides up to the chemical formula $\mathrm{Li}_{2} \mathrm{C}_{6}$, and $1116 \mathrm{mAh} \mathrm{g}^{-1}$ if $\mathrm{Li}$ can be trapped at the benzene rings up to $\mathrm{LiC}_{2}$, but these targets have not been achieved by using pure graphene materials [78]. Pan et al. [72] have investigated the mechanism of the lithiation of the rGO anode. The GCD profiles show a first cycle lithiation peak at $800 \mathrm{mV}$ and a secondary lithiation event beginning around $250 \mathrm{mV}$ and intensifying down to the cutoff voltage of $10 \mathrm{mV}$. The first cycle charge capacity at a rate of $\mathrm{C} / 20$ was nearly $1200 \mathrm{mAh} \mathrm{g}^{-1}$ and then dropped steadily to $350 \mathrm{mAh} \mathrm{g}^{-1}$, where it stabilized after 20 cycles. The rate capability leads the capacity of $\sim 200 \mathrm{mAh} \mathrm{g}^{-1}$ at a rate of C/5 and $\sim 100 \mathrm{mAh} \mathrm{g}^{-1}$ at a rate of 1C. Wang et al. [79] observed a first cycle capacity of $700 \mathrm{mAh} \mathrm{g}^{-1}$ with an immediate decrease to $100 \mathrm{mAh} \mathrm{g}^{-1}$ in the second cycle at a rate of C/7.5. The high irreversible first cycle capacity is due to the electrochemical reactions contributing to solid-electrolyte interphase (SEI) layer formation. It is also well known that the capacity of rGO anodes is sensitive to the preparation method. Solar reduced graphene oxide (SrGO) proved to be an excellent anode material in Li-ion batteries. The SrGO material was obtained by a thermal reduction and exfoliation of GO spread over Petri disk and sun-lighted [80]. This material exhibits first cycle discharge and charge capacities as high as 1480 and $880 \mathrm{mAh} \mathrm{g}{ }^{-1}$, respectively. Moreover, the coulombic efficiency (CE) was found to be $>95 \%$ and the specific capacity after 60 cycles was $>500 \mathrm{mAh} \mathrm{g}^{-1}$ [81].

\section{3. rGO-Based Composites}

Currently, the typical process to fabricate a $M \mathrm{O}_{\mathrm{x}} / \mathrm{rGO}$ composite consists in the preparation of GO by the modified Hummers' method and then attach/grow $M \mathrm{O}_{\mathrm{x}}$ nanoparticles (NPs) on the GO, followed by a reduction process to transform GO to rGO [82,83]. Various strategies for the fabrication of nanostructured composites have been proposed, including mixed model [84], encapsulated model [85], wrapped model [86], anchored model [87], sandwich-like model [88], and layer model [34]. Among them, the sandwich-like model appears to be a smart choice to take combinations of both the electrochemically active material and the rGO matrix in an ordered arrangement. Figure 2 shows the different structural models of MOx-based composites [34].
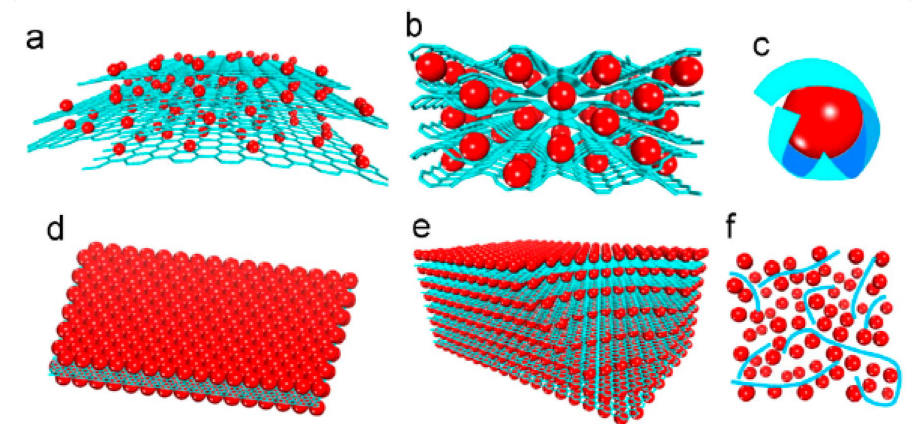

Figure 2. Schematic of structural models of $\mathrm{GO} / \mathrm{MO}_{\mathrm{x}}$ composites. (a) Anchored model. (b) Wrapped model. (c) Encapsulated model. (d) Sandwich-like model. (e) Layered model. (f) Mixed model (red: Metal oxide particles; blue: Graphene sheets). Reproduced with permission from [34]. Copyright 2012 Elsevier.

The theoretical specific capacity, $C_{\text {theor, }}$ of the hypothetical metal oxide/reduced graphene oxide mixture $\left(\mathrm{MO}_{\mathrm{x}} / \mathrm{rGO}\right)$ can be calculated through the equation:

$$
C_{\text {theor }}=C_{M O x} \times m_{M O x}+C_{\mathrm{rGO}} \times m_{\mathrm{rGO}} \text {, }
$$


where $C_{M O x}$ and $m_{M O x}$ are the theoretical specific capacity and mass percentage of metal oxide (wt $\%$ ), respectively, and $C_{\mathrm{rGO}}$ and $m_{\mathrm{rGO}}$ are the theoretical specific capacity and mass percentage of rGO, respectively. The value of $C_{\mathrm{rGO}}$ in the potential range of $1-3 \mathrm{~V}\left(744 \mathrm{mAh} \mathrm{g}^{-1}\right)$ is used to estimate the theoretical capacity of these composites [89].

\section{Single Element/GO or rGO Composites}

\subsection{Silicon}

Among all existing anode materials, silicon has the high theoretical specific capacity of $4200 \mathrm{mAh} \mathrm{g}^{-1}$, which corresponds to $4.4 \mathrm{Li}^{+}$per $\mathrm{Si}$ atom to form $\mathrm{Li}_{4.4} \mathrm{Si}$ alloy. The huge volume change $(\sim 400 \%)$ in the lithiation/delithiation process results in loss of electrical contact of Si powders and structural cracking, implying poor cycle ability of Si anodes. To overcome this problem, the best anodes consist in Si nanoparticles dispersed in a carbon matrix, referred to as Si/C anodes. Nano-size is needed to alleviate the volume change during cycling, and the dispersion of carbon is needed to maintain electrical contact [90-95]. Since the first preparation of Si/graphene hybrid by Chou et al. in 2010 [96] constant progress in the preparation of Si/C electrodes for LIBs has been obtained through the years, even though some drawbacks still exist, such as low first coulombic efficiency [97].

As mentioned in the introduction, this review is focused on rGO-supported anodes, which are closer to commercial use than graphene-supported anodes. However, it may be useful to mention few results obtained this year on $\mathrm{Si} /$ graphene anodes, which illustrate the best results observed with such a composite, for comparison with the results obtained with $\mathrm{Si} / \mathrm{rGO}$ anodes detailed hereunder. Jamaluddin at al. reported a Si@graphene composite with a ball-like structure [98]. The graphene sheets were obtained by an electrochemical exfoliation method from natural graphite. The Si@graphene composite was then obtained by a spray drying process, with a void space in the core-shelled ball structure inside the site. The void space helps in the accommodation of the volume change during cycling. $2882.3 \mathrm{mAh} \mathrm{g}^{-1}$ and an initial coulombic efficiency of $86.9 \%$ at $0.2 \mathrm{~A} \mathrm{~g}^{-1}$ was observed. At $0.5 \mathrm{~A} \mathrm{~g}^{-1}$, the capacity maintained at $1063 \mathrm{mAh} \mathrm{g}^{-1}$ after 100 cycles. Si/multilayer graphene (thickness controlled to $2 \mathrm{~nm}$ ) delivered a capacity of $990 \mathrm{mAh} \mathrm{g}^{-1}$ at $1 \mathrm{~A} \mathrm{~g}^{-1}$ after 500 cycles. At $4 \mathrm{~A} \mathrm{~g}^{-1}$, the capacity was $1164.5 \mathrm{mAh} \mathrm{g}^{-1}$ [99]. This result was attributed to the formation of a silicon oxycarbide interlayer formed by a rapid cooling during the synthesis process of the composite. Both graphene and GO can also be used in the same anode in combination with Si. Spherical graphite/silicon/graphene oxides/carbon $(\mathrm{Gr} / \mathrm{Si} / \mathrm{GO} / \mathrm{C})$ composite was prepared by Huang et al. by electrostatic self-assembly and spray drying process [100]. This composite delivered a capacity of $1212 \mathrm{mAh} \mathrm{g}^{-1}$ at $200 \mathrm{~mA} \mathrm{~g}^{-1}$ with a capacity retention rate of $81.7 \%$ after 100 cycles.

Si@rGO composites are considered as promising anodes for the next generation of LIBs. It was shown that the particle morphology, specific surface area, and architecture of hybrids are the key issues optimizing the electrochemical performance. For example, Kim et al. have recently prepared a 2D multi-layered Si/rGO hybrid anode by direct growth of Si intercalated into a porous multi-layered rGO film, in which the porous rGO network acts as a cushion against the expansion of the Si layer during lithiation [101]. The templated self-assembly (TSA) strategy seems to be another efficient way for the preparation of Si/rGO composite [102-105]. In a typical TSA method, the self-assembled rGO/Si solution was acquired by mild stirring for $2 \mathrm{~h}$ and dialysis in absolute ethanol several times and then transferred to a hydrothermal reactor for reduction at $80^{\circ} \mathrm{C}$ for $3 \mathrm{~h}$ by sodium borohydride [105].

In 2012, Chockla et al. [32] investigated the lithiation/delithiation process in binder-free rGO-supported Ge and Si nanowires (NWs) as negative electrode materials in LIBs. In the Si/Ge $\mathrm{NWs} / \mathrm{rGO}$ composite, there is a competition between $\mathrm{rGO}$ and $\mathrm{Si} / \mathrm{Ge}$ lithiation. At a high cycling rate $(>0.1 \mathrm{C})$ the rGO lithiation dominates, while at low cycle rates $(<0.1 \mathrm{C})$ and high Si/Ge loading only Si and Ge are lithiated. The Si NWs/rGO electrode was stabilized to a small extent but the specific capacity was low and dropped to less than $100 \mathrm{mAh} \mathrm{g}^{-1}$ for when the rate was increased from C/20 to C/10. Wang et al. [88] developed a novel type of self-supporting binder free silicon-based negative electrode 
through the encapsulation of silicon nanowires (SiNWs) with dual adaptable apparels (overlapped graphene sheaths and rGO overcoats). The resulting SiNWs@G/rGO composite gave high reversible capacity of $1600 \mathrm{mAh} \mathrm{g}^{-1}$ at $2.1 \mathrm{~A} \mathrm{~g}^{-1}$ current rate and $80 \%$ capacity retention over 100 cycles. A rate capability of $500 \mathrm{mAh} \mathrm{g}^{-1}$ at $8.4 \mathrm{~A} \mathrm{~g}^{-1}$ (on the basis of the total electrode weight) was demonstrated. Two advantages of such an architecture were discussed. Firstly, sealed and adaptable coated graphene sheets avoid the direct contact of encapsulated silicon and electrolyte, enabling the structural and interfacial stabilization. Secondly, the flexible and conductive rGO network controls the pulverization of the electrode and provides the conductive homogeneity to the composite. It is generally accepted that the creation of defects in the graphitic planes of graphene by replacing the carbon atom with heteroatoms increases its electrochemical performance. [106]. Chang et al. [107] prepared a Si/rGO hybrid composite anode with over 20 layers with excellent electrochemical performance at $3 \mathrm{C}$ rate. A control sample of $\mathrm{Si} / \mathrm{rGO}$ composite was prepared using pristine Si nanoparticles and GO (weight ratio of $\mathrm{Si}$ to $\mathrm{GO}=3: 2$ ) by self-assembly process mediated by electrostatic attraction [103]. The $\mathrm{Si} / \mathrm{rGO}$ composite containing $64.6 \mathrm{wt} \% \mathrm{Si}$ exhibits a capacity of $512 \mathrm{mAh} \mathrm{g}^{-1}$ after 40 cycles at current density of $200 \mathrm{~mA} \mathrm{~g}^{-1}$ between voltage limits of $0.05-1.2 \mathrm{~V} \mathrm{vs} \mathrm{Li}^{+} / \mathrm{Li}$. In 2015 , Chang et al. fabricated an anode constituted by 3D carbon-coated $\mathrm{Si} / \mathrm{rGO}$ nanostructure anchored by nickel foam with carbon nanotubes using Si NPs and GO sheets in poly(methyl methacrylate solution [87]. The carbon-coated Si NPs/rGO hybrid displays a high reversible capacity up to $2700 \mathrm{mAh} \mathrm{g}^{-1}$ at a current density of $0.05 \mathrm{C}\left(130 \mathrm{~mA} \mathrm{~g}^{-1}\right)$ and $70 \%$ capacity retention (up to $1311 \mathrm{mAh} \mathrm{g}^{-1}$ ) at $2.6 \mathrm{~A} \mathrm{~g}^{-1}$ current rate after 900 cycles. Lin et al. [108] developed a Si@carbon/rGO composite with the assistance of polyaniline (PANI), which can glue to combine Si nanoparticles with GO and can be pyrolyzed as carbon coating layer. The Li storage performance of this assembled hybrid, which delivers a reversible capacity of $1121 \mathrm{mAh} \mathrm{g}^{-1}$ at a current density of $0.9 \mathrm{~A} \mathrm{~g}^{-1}$ over 230 cycles with CE of $81.1 \%$, comparing well with that of the Si@carbon anode ( $495 \mathrm{mAh} \mathrm{g}^{-1}$ at $0.3 \mathrm{~A} \mathrm{~g}^{-1}$ after 50 cycles). A CNT/rGO/Si nanoparticle composite anode showing high rate and long cycle life was prepared by a layer-by-layer assembly process. In this structure, rGO completely wrapped the entire Si/CNT networks by different layers and CNT networks provide fast electron transport pathways. The CNT/rGO/Si-NPs composite exhibits high performances with long cycle life; it delivers a specific capacity of $455 \mathrm{mAh} \mathrm{g}^{-1}$ at $15 \mathrm{~A} \mathrm{~g}^{-1}$ after 2000 cycles, high specific charge capacity of 2250 and $650 \mathrm{mAh} \mathrm{g}^{-1}$ at 0.2 and $15 \mathrm{~A} \mathrm{~g}^{-1}$ current rate, respectively, and fast charge/discharge rates up to $16 \mathrm{~A} \mathrm{~g}^{-1}$ [109].

Recently, a multi-layered structure obtained by tuning the interface chemistries of $\mathrm{GO}$ and siloxene sheets as anode delivered $3880 \mathrm{mAh} \mathrm{g}^{-1}$ at $205 \mathrm{~mA} \mathrm{~g}^{-1}$, and still $1040 \mathrm{mAh} \mathrm{g}^{-1}$ after 1000 cycles at $4.1 \mathrm{~A} \mathrm{~g}^{-1}$ [110]. The fabrication of $\mathrm{Si@SnS} / 2 / \mathrm{rGO}$ composite anodes for high-capacity Li-ion batteries was achieved by Dai et al. [111]. The composite is formed by Si nanoparticles (30 nm in size) anchored on a $3 \mathrm{D}$ rGO network and mixed with $\mathrm{SnS}_{2}$, which provides space-constraining effects to accommodate volume expansion and particle aggregation. The $\mathrm{Si} @ \mathrm{SnS}_{2} / \mathrm{rGO}$ composite presents a high specific capacity of $1480 \mathrm{mAh} \mathrm{g}^{-1}$ after 200 cycles at a current density of $0.2 \mathrm{~A} \mathrm{~g}^{-1}$ and a high stability at rates of $0.2-3.0 \mathrm{~A} \mathrm{~g}^{-1}$. A stable specific capacity of $425 \mathrm{mAh} \mathrm{g}^{-1}$ was achieved after 600 cycles at a current density of $3 \mathrm{~A} \mathrm{~g}^{-1}$. Deng et al. [112] reported the properties of a layer-by-layer coated nanocomposite anode fabricated by a scalable laser shock assisted roll-to-roll deposition process. The Si NPS/rGO hybrid can deliver a high specific capacity of $1956 \mathrm{mAh} \mathrm{g}^{-1}$ at a high cyclic rate of $15 \mathrm{~A} \mathrm{~g}^{-1}$ and can retain $71.3 \%$ of the initial capacity after 1000 cycles. A prototype full-cell using a slurry-cast $\mathrm{LiNi}_{0.6} \mathrm{Mn}_{0.2} \mathrm{Co}_{0.2} \mathrm{O}_{2}$ (NMC622) cathode with a mass loading of $7 \mathrm{mg} \mathrm{cm}^{-2}$ was built to demonstrate the performance of the $\mathrm{Si} / \mathrm{rGO}$ composite anode (with mass loading of $0.5 \mathrm{mg} \mathrm{cm}^{-2}$ ) to form the full-cell. The NMC622||Si/rGO full-cell delivers a good areal capacity of $0.95 \mathrm{mAh} \mathrm{cm}^{-2}$ at a charge/discharge rate of $0.25 \mathrm{~mA} \mathrm{~cm}^{-2}$ and $0.70 \mathrm{mAh} \mathrm{cm}^{-2}$ at $1 \mathrm{~mA} \mathrm{~cm}^{-2}$ in a voltage window $2.0-4.3 \mathrm{~V}$. In addition, a $98 \%$ capacity retention after 50 cycles at $0.25 \mathrm{~mA} \mathrm{~cm}^{-2}$ and a high energy density of $467 \mathrm{Wh} \mathrm{kg}^{-1}$ with an average voltage of $\sim 3.58 \mathrm{~V}$ are achieved. A Si/rGO composite used as an active element of an anode with mass loading of $1.0-1.2 \mathrm{mg} \mathrm{cm}^{-2}$ delivered a capacity of $894 \mathrm{mAh} \mathrm{g}^{-1}$ over 100 cycles at $0.2 \mathrm{~A} \mathrm{~g}^{-1}$, and demonstrated a high-rate capability, with a capacity of $513 \mathrm{mAh} \mathrm{g}^{-1}$ retained at $5 \mathrm{~A} \mathrm{~g}^{-1}$ [113]. 
Si nanoparticles veiled with ultrathin $\mathrm{rGO}$ film reduced directly by precoated Ni template delivered capacity of 975 and $717 \mathrm{mAh} \mathrm{g}^{-1}$ after 300 cycles at 1 and $3 \mathrm{~A} \mathrm{~g}^{-1}$, respectively [114].

Several reports are related to the Si/rGO mesoporous-like architectures [115-120]. A 3D porous micro-size pomegranate shaped nano-silicon and rGO composite delivered a capacity of $1200 \mathrm{mAh} \mathrm{g}^{-1}$ after 300 cycles at $0.5 \mathrm{~A} \mathrm{~g}^{-1}$ [121]. Si particles encapsulated by rGO and forming a mesoporous structure delivered $1548 \mathrm{mAh} \mathrm{g}^{-1}$ at $200 \mathrm{~mA} \mathrm{~g}^{-1}$ after 100 cycles, and $905 \mathrm{mAh} \mathrm{g}^{-1}$ after 100 cycles at $1 \mathrm{Ag}^{-1}$ [116]. A lower cost and scalable synthesis of Si@rGO composite was proposed by Benzait et al. [122]. First, low-cost Al-Si (80:20) powder was chosen as the precursor instead of the higher-priced Si. Then, nanostructured porous $\mathrm{Si}$ was obtained by chemical dealloying with etching of $\mathrm{Al}$ using hydrochloric acid. This Al-etching reaction produces hydrogen allowing the reduction of GO to rGO simultaneously. This process thus avoids the post-treatment usually needed to reduce GO. This composite delivered a capacity of $1080 \mathrm{mAh} \mathrm{g}^{-1}$ at $0.2 \mathrm{~A} \mathrm{~g}^{-1}$ after 250 cycles, and $840 \mathrm{mAh} \mathrm{g}^{-1}$ at $4 \mathrm{~A} \mathrm{~g}^{-1}$. Liang et al. reported the fabrication of highly porous Si@C network derived from rice husks through activation and subsequent calcinations and consolidation by rGO introduced via ultrasonication [119]. The 3D carbon-coated mesoporous Si nanospheres@graphene foam (C@Si/GF) nanoarchitectures, synthesized by a thermal bubble ejection assisted chemical-vapor-deposition and magnesiothermic reduction method, exhibits superior anode performance including a specific capacity of $1200 \mathrm{mAh} \mathrm{g}^{-1}$ at $1 \mathrm{~A} \mathrm{~g}^{-1}$ current rate and shows stable morphology after 200 cycles [120].

The Si@C/rGO product having a high specific surface area of $539 \mathrm{~m}^{2} \mathrm{~g}^{-1}$ and pore volume of $0.693 \mathrm{~cm}^{3} \mathrm{~g}^{-1}$ achieved enhanced electrochemical properties with a stable capacity of $760 \mathrm{mAh} \mathrm{g}^{-1}$ after 80 cycles and a capacity of $317 \mathrm{mAh} \mathrm{g}^{-1}$ at $1 \mathrm{~A} \mathrm{~g}^{-1}$ current rate. Another highly porous composite was prepared by a templated self-assembly procedure with $x \mathrm{rGO}$ :Si ratios $(x=5,10,15)$ and optimized by calcination. The specific surface area of $482 \mathrm{~m}^{2} \mathrm{~g}^{-1}$ for rGO/Si composite $(x=10)$ increased to $539 \mathrm{~m}^{2} \mathrm{~g}^{-1}$ after a calcination at $600{ }^{\circ} \mathrm{C}$ for $4 \mathrm{~h}$ in Ar environment. The optimized composite displayed an initial discharge capacity of $2317 \mathrm{mAh} \mathrm{g}^{-1}$ (ICE of $93.2 \%$ ) and a capacity retention of $85 \%$ after 100 cycles at $0.1 \mathrm{~A} \mathrm{~g}^{-1}$ rate. At a higher current density of $2 \mathrm{~A} \mathrm{~g}^{-1}$, this electrode delivered a specific capacity of $728 \mathrm{mAh} \mathrm{g}^{-1}$ after 100 cycles [105]. Song's group [123] prepared Si nanoparticles (Si-NPs) enwrapped in $\mathrm{N}$-doped carbon and combine with N-doped $\mathrm{rGO}$ and CNTs by solution-mixing and subsequent carbonization process using pyrolyzing melamine formaldehyde resin (MFR). The Si-NPs/rGO/CNTs composite, in which N-doped carbon outside Si-NPs buffers the volume change, exhibited a high reversible capacity of $892 \mathrm{mAh} \mathrm{g}^{-1}$ after 100 cycles at a current density of $100 \mathrm{~mA} \mathrm{~g}^{-1}$, good rate capability, and cycling stability.

Zhang et al. [124] proposed a facile template-sacrificing method to fabricate bowl-like Si@rGO hybrids using uniform $\mathrm{SiO}_{2}$ spheres wrapped by GO. The reduced 3D bowl-like nanoarchitecture resulting in Si nanoparticles distributed on the flexible rGO layer exhibited a high first discharge capacity of $\sim 1890 \mathrm{mAh} \mathrm{g}^{-1}$ with a CE of $90.79 \%$ at a current density of $0.1 \mathrm{~A} \mathrm{~g}^{-1}$. A stable specific capacity of $450 \mathrm{mAh} \mathrm{g}^{-1}$ was achieved after 100 cycles. More recently, Majeed et al. [116] fabricated a clay-derived mesoporous $\mathrm{Si} / \mathrm{rGO}$ composite using a cost-effective and scalable process (i.e., one-pot magnesiothermic reduction), in which Si nanoparticles are encapsulated by rGO. Montmorillonite clay were used as natural resource for Si. This suitable mesoporous (with $89.2 \mathrm{~m}^{2} \mathrm{~g}^{-1}$ specific surface area) anode material for LIBs shows an enhanced capacity of $1548 \mathrm{mAh} \mathrm{g}^{-1}$ after 100 cycles at $200 \mathrm{~mA} \mathrm{~g}^{-1}$ current rate.

Since 2016, a large amount of research was focused on ternary composites showing superior electrochemical performance with long-term stability. Chen et al. [125] reported the fabrication of an electrospun sandwich-structured silicon-based anode with an architecture of rGO-protected silicon/carbon nanofibers (CNF) inhibiting the fragmentation of silicon electrodes typically caused by the large volume changes during charge/discharge reactions. This composite exhibited a high specific capacity of $1055 \mathrm{mAh} \mathrm{g}^{-1}$ up to 130 cycles at $0.1 \mathrm{~A} \mathrm{~g}^{-1}$. The Si/CNFs@rGO electrode also demonstrated outstanding rate behavior with a reversible capacity of $358 \mathrm{mAh} \mathrm{g}^{-1}$ at $5.0 \mathrm{~A} \mathrm{~g}^{-1}$. Pan et al. [126] prepared a micro-sized ternary Si@C@rGO spherical composite by a scalable spray drying technique 
and a subsequent calcination process. The obtained Si@C@rGO anode delivered a high initial reversible specific capacity of $1599 \mathrm{mAh} \mathrm{g}^{-1}$ at a current density of $0.1 \mathrm{~A} \mathrm{~g}^{-1}$ with a good capacity retention of $94.9 \%$ at a higher current rate of $0.2 \mathrm{Ag}^{-1}$. Moreover, the Si@C@rGO anode demonstrated a good rate capability with a capacity of $951 \mathrm{mAh} \mathrm{g}^{-1}$ at $2 \mathrm{~A} \mathrm{~g}^{-1}$. According to the EIS results, the incorporation of graphene inhibited the growth of the SEI layer and enhanced the cycling stability of the electrode. The Si/rGO/C composite was prepared by encapsulating graphene-coated Si nanoparticles in the interconnected carbon nanofibers based on electrospinning technology [127]. This hierarchical core-shell nanofibers $\mathrm{Si} / \mathrm{rGO} / \mathrm{C}$ NFs demonstrated excellent electrochemical performance with a reversible capacity of $1228 \mathrm{mAh} \mathrm{g}^{-1}$ and a capacity retention of $72 \%$ after 100 cycles with a current density of $0.8 \mathrm{~A} \mathrm{~g}^{-1}$. When the current rate increased to $4 \mathrm{~A} \mathrm{~g}^{-1}$, the anode displayed superior rate capability with a specific capacity of $954 \mathrm{mAh}^{-1}$. Lee and coworkers [128] synthesized $\mathrm{rGO} / \mathrm{Si}$ composite via a simple dip-coating method with nickel foam as a current collector and template for the electrode fabrication. The rGO/Si hybrid anode with $0.03 \mathrm{wt} \%$ Si delivered a capacity of $778 \mathrm{mAh} \mathrm{g}^{-1}$ after 100 cycles.

Porous $\mathrm{Si} / \mathrm{C} /$ reduced graphene oxide $(\mathrm{Si} / \mathrm{C} / \mathrm{rGO})$ microspheres were prepared by the Tao's group [129] using spray drying and subsequent carbonization process with polyvinyl alcohol (PVA) as cross-linking agent. The rGO wrapped $\mathrm{Si} / \mathrm{C}$ ball structure offers a buffer space for the volume change of Si during the charge-discharge process. The as-prepared Si/C/rGO anode exhibited a high reversible capacity of $928 \mathrm{mAh} \mathrm{g}^{-1}$ after 70 cycles at a current density of $0.1 \mathrm{~A} \mathrm{~g}^{-1}$, and a good rate capability. An electrostatic self-assembly method was proposed to fabricate ball-milling-silicon@carbon/rGO composite (bmSi@C/rGO) using chitosan as a charged bridge [104]. The composite with 5-nm thick carbon coating and $20.4 \mathrm{wt} \%$ rGO tested as anode material displayed high reversible capacity of $935 \mathrm{mAh} \mathrm{g}^{-1}$ at $0.2 \mathrm{~A} \mathrm{~g}^{-1}$ current rate in the potential range of $0.02-1.5 \mathrm{~V} \mathrm{vs} \mathrm{Li}^{+/} \mathrm{Li}$ and $71.9 \%$ capacity retention after 100 cycles. In 2017, Qin et al. [130] reported the preparation of binder-free, conductive agent-free Si/rGO anode on nickel foam via one-step hydrothermal method with subsequent post-annealing process. This anode material demonstrated a remarkable cycle ability and rate performance, i.e., reversible specific capacity of $1500 \mathrm{mAh} \mathrm{g}^{-1}$ at $2 \mathrm{~A} \mathrm{~g}^{-1}$ current rate after 2500 cycles and over $600 \mathrm{mAh} \mathrm{g}^{-1}$ at $4 \mathrm{~A} \mathrm{~g}^{-1}$ after 2500 cycles. The rate capability of $500 \mathrm{mAh} \mathrm{g}^{-1}$ was still maintained at high current density of $16 \mathrm{~A} \mathrm{~g}^{-1}$ (Figure 3).
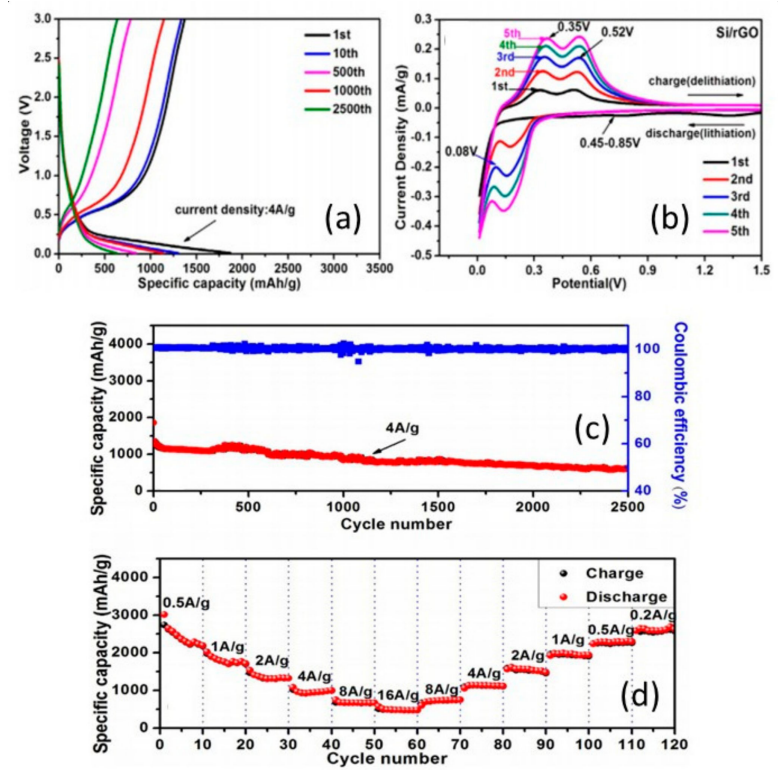

Figure 3. Electrochemical characterization of the binder-free, conductive agent-free Si/rGO anode. (a) Galvanostatic discharge/charge profiles from the 1st to 2500th cycle at $4 \mathrm{~A} \mathrm{~g}^{-1}$ current rate. (b) Cyclic voltammograms for the first five cycles. (c) Cyclability upon 2500 cycles at $4 \mathrm{~A} \mathrm{~g}^{-1}$ current rate. (d) Rate capability at various current densities from 0.5 to $16 \mathrm{~A} \mathrm{~g}^{-1}$ and finally back to $0.2 \mathrm{~A} \mathrm{~g}^{-1}$. Reproduced with permission from [130]. Copyright 2018 Elsevier. 
Recently, 3D-framework Si@N-doped C/rGO composite was synthesized by a novel polymer network method using acrylic amide and $N, N^{\prime}$-methylene bisacrylamide as the crosslinker [131]. After the crosslinking process, Si nanoparticles ( $30 \mathrm{~nm}$ in size) were embedded in a $\mathrm{N}$-doped $\mathrm{C} / \mathrm{rGO}$ sheet-like network. As an anode, this composite delivered a first discharge capacity of $2609 \mathrm{mAh} \mathrm{g}^{-1}$, an ICE of $69 \%$ and demonstrated a capacity of $\sim 479 \mathrm{mAh} \mathrm{g}^{-1}$ after 200 cycles at $2 \mathrm{~A} \mathrm{~g}^{-1}$ with a CE of $99.6 \%$. A yolk-shell structured $\mathrm{rGO} /$ multi-walled carbon nanotubes (MWCNT)-based hybrid as binder-free anode material was designed and investigated for different MWCNT:rGO ratios by Toçoğlu and coworkers [132]. In this configuration, the void space between Si nanoparticles (50-150 nm) and carbon coating created by the yolk-shell architecture buffered the Si volume expansion. The rGO/MWCNT/Si@void@C free-standing composite with MWCNT:rGO of 2:1 tested at $200 \mathrm{~mA} \mathrm{~g}^{-1}$ current rate in the voltage range $0.05-2.5 \mathrm{~V}$ delivered specific discharge capacities of 2472 and $1621 \mathrm{mAh} \mathrm{g}^{-1}$ at the first and second cycle, respectively. After 500 cycles at the current rate of $200 \mathrm{~mA} \mathrm{~g}^{-1}$, the composite anodes with MWCNT:rGO ratios of 1:1, 1:2, 2:1 delivered capacities of 820, 503, and $951 \mathrm{mAhg}^{-1}$, respectively, while the rGO/Si@void@C (without MWCNT) exhibited only $500 \mathrm{mAhg}^{-1}$. A green-synthetic spiderweb-like hybrid composed of Si nanoparticles encapsulated by a multifunctional citric acid binder (SiNPs@CA) anchored on rGO sheets through chemical bonds was characterized as anode material [133]. The SiNPs@CA@rGO anode retained a capacity of $2566 \mathrm{mAh} \mathrm{g}^{-1}$ after 100 cycles at a current density of $1 \mathrm{~A} \mathrm{~g}^{-1}$ with an ICE of $81 \%$. Kinetic measurements by EIS and GITT methods showed that $\mathrm{Li}^{+}$diffusion coefficients are in the range $10^{-8}-10^{-10} \mathrm{~cm}^{2} \mathrm{~s}^{-1}$. Wu et al. [134] prepared ternary hierarchical Si/rGO/C composites by encapsulating Si nanoparticles into the rGO/C dual-carbon matrix via self-assembling, ball milling, polystyrene sphere (PSS) template-assisting, and spray drying techniques. When cycled at $0.4 \mathrm{~A} \mathrm{~g}^{-1}$ for 500 cycles, the $\mathrm{Si} / \mathrm{rGO} / \mathrm{C}$ anode showed a capacity retention of $\sim 75 \%$ and CE of $\sim 99.7 \%$ retaining a specific capacity of $\sim 602 \mathrm{mAh} \mathrm{g}^{-1}$. Yu et al. [135] employed a synthesis process in mild conditions free of reducing agent to fabricate $\mathrm{rGO} / \mathrm{Si}$ and $\mathrm{N}$-doped rGO/C@Si composites. Analysis of the peak strength ratio of D- and G-Raman band $\left(I_{\mathrm{D}} / I_{\mathrm{G}}\right)$ showed that $\mathrm{rGO} / \mathrm{C} @ \mathrm{Si}$ had the higher degree of graphitization $\left(I_{\mathrm{D}} / I_{\mathrm{G}}=0.87\right)$ compared with $\mathrm{rGO} / \mathrm{Si}\left(I_{\mathrm{D}} / I_{\mathrm{G}}=1.04\right)$. Due to the increased affinity to lithium of amorphous carbon, the designed N-doped rGO/C@Si anode material (29.1 wt\% GO; specific surface area of $\sim 86 \mathrm{~m}^{2} \mathrm{~g}^{-1}$; pore volume of $0.13 \mathrm{~cm}^{3} \mathrm{~g}^{-1}$ ) showed superior cycling performance, i.e., specific capacity of $1115.8 \mathrm{mAh} \mathrm{g}^{-1}$ after 150 cycles at $0.42 \mathrm{~A} \mathrm{~g}^{-1}$ and better rate capability of $1077 \mathrm{mAh} \mathrm{g}^{-1}$ at $4.2 \mathrm{~mA} \mathrm{~g}^{-1}$. Pomegranate-like Si@N-doped C/rGO composites were successfully fabricated by in-situ nitrogen doped carbon coating and freeze-drying processes [116]. The composite anode with $\sim 84 \% \mathrm{Si}$ (spherical nanoparticles with average diameter of $50 \mathrm{~nm}$ ) presented an initial discharge capacity of $\sim 1717 \mathrm{mAh} \mathrm{g}^{-1}$, an ICE of $70.7 \%$, and a charge specific capacity of $709 \mathrm{mAh} \mathrm{g}^{-1}$ at $1 \mathrm{~A} \mathrm{~g}^{-1}$ after 400 cycles. The capacity was still $532 \mathrm{mAh} \mathrm{g}^{-1}$ at $3 \mathrm{~A} \mathrm{~g}^{-1}$. The Si@N-doped C/rGO anode demonstrated a slightly increasing $D_{L i}{ }^{+}$from $8.08 \times 10^{-14}$ to $8.50 \times 10^{-14} \mathrm{~cm}^{2} \mathrm{~s}^{-1}$ after 100 cycles. Recently, Zhu et al. fabricated an anode with yolk-void-shell Si-C particles strongly anchored on rGO [136]. The Si@void@C/rGO with a void size of $5 \mathrm{~nm}$ delivered a capacity of $1294 \mathrm{mAh} \mathrm{g}^{-1}$ after 100 cycles at $0.5 \mathrm{~A} \mathrm{~g}^{-1}$. Electrochemical performance of Si/rGO composite anodes from the recent literature are summarized in Table 1.

Table 1. Electrochemical performance of $\mathrm{Si} / \mathrm{rGO}$ composites. The relevant cycle number is displayed in brackets.

\begin{tabular}{|c|c|c|c|c|}
\hline Material & Synthesis & $\begin{array}{l}\text { Specific Capacity } \\
\left(\mathrm{mAh} \mathrm{g}^{-1}\right)\end{array}$ & $\begin{array}{c}\text { Current Density } \\
\left(\mathrm{A} \mathrm{g} \mathrm{g}^{-1}\right)\end{array}$ & Ref. \\
\hline SiNWs@G/rGO & sandwich procedure & 1280 & $2.1(100)$ & [88] \\
\hline Si NPs/rGO & polymer-assisted & 1311 & $2.6(900)$ & [87] \\
\hline Si/CNFs@rGO & layer-by-layer assembly & 455 & $15(2000)$ & {$[109]$} \\
\hline $\mathrm{CNT} / \mathrm{rGO} / \mathrm{Si}-\mathrm{NPs}$ & electrostatic method & 1480 & $0.2(200)$ & {$[111]$} \\
\hline $\mathrm{Si} @ \mathrm{C} / \mathrm{rGO}$ & sonication + calcination & 780 & $1.0(80)$ & {$[119]$} \\
\hline Si NPS/rGO & roll-to-roll deposition & 1394 & $15(1000)$ & [112] \\
\hline $\mathrm{Si} / \mathrm{rGO}$ & self-assembly & 1481 & $0.5(50)$ & {$[102]$} \\
\hline
\end{tabular}


Table 1. Cont.

\begin{tabular}{|c|c|c|c|c|}
\hline Material & Synthesis & $\begin{array}{l}\text { Specific Capacity } \\
\left(m A h g^{-1}\right)\end{array}$ & $\begin{array}{l}\text { Current Density } \\
\left(\mathrm{A} \mathrm{g}^{-1}\right)\end{array}$ & Ref. \\
\hline 3D Si/rGO & evaporation & 1406 & $0.05(100)$ & {$[117]$} \\
\hline $\mathrm{Si} @ \mathrm{SnS}_{2} / \mathrm{rGO}$ & electrostatic self-assembly & 1055 & $0.1(130)$ & [125] \\
\hline Si@C@rGO & spray drying + calcination & 1567 & $0.2(100)$ & [126] \\
\hline Si@N-doped C/rGO & polymer network method & 479 & $2.0(200)$ & [131] \\
\hline $\mathrm{Si} / \mathrm{C} / \mathrm{rGO}$ & spray-drying + carbonization & 928 & $0.1(70)$ & [129] \\
\hline $\mathrm{Si} / \mathrm{rGO} / \mathrm{C} \mathrm{NFs}$ & electrospinning & 884 & $0.8(100)$ & {$[127]$} \\
\hline bmSi@C/rGO & ball-milling + pyrolysis & 935 & $0.2(100)$ & [104] \\
\hline Si@N-doped C/rGO & freeze drying & 709 & $1.0(400)$ & {$[117]$} \\
\hline N-doped rGO/C@Si & freeze-drying + pyrolysis & 1115 & $0.42(150)$ & [135] \\
\hline $\mathrm{Si} / \mathrm{rGO} / \mathrm{C}$ & self-assembling + spray-drying & 602 & $0.4(500)$ & {$[134]$} \\
\hline rGO/MWCNT/Si@void@C & dispersion + ultrasonication & 951 & $0.2(500)$ & [116] \\
\hline rGO/Si@void@C & dispersion + ultrasonication & 500 & $0.2(500)$ & [132] \\
\hline SiNPs@CA@rGO & suspension + freeze drying & 2566 & $1.0(100)$ & [133] \\
\hline Si@rGO (bowl-like) & templating & 450 & $0.1(100)$ & {$[124]$} \\
\hline $\mathrm{Si} / \mathrm{rGO} @ \mathrm{Ni}$ foam & hydrothermal & 1500 & $2(2500)$ & [130] \\
\hline Si@Void@C/rGO & surface carbonization + etching & 1294 & $0.5(100)$ & {$[136]$} \\
\hline
\end{tabular}

\subsection{Germanium}

Germanium has important advantages over Si: A better electronic conductivity $\left(2.1 \mathrm{~S} \mathrm{~cm}^{-1}\right)$ and higher Li-ion diffusivity $\left(6.5 \times 10^{-12} \mathrm{~cm}^{2} \mathrm{~s}^{-1}\right)$, and a huge theoretical capacity of $1624 \mathrm{mAh} \mathrm{g}^{-1}$; since it can be lithiated to $\mathrm{Li}_{15} \mathrm{Ge}_{4}\left(4.4 \mathrm{Li}^{+}\right.$per Ge atom $)$at low operating voltage $\left(0.3 \mathrm{~V} \mathrm{vs} \mathrm{Li}^{+/} \mathrm{Li}\right)$ [137]. Reported phases of $\mathrm{Li}-\mathrm{Ge}$ alloys include $\mathrm{Li}_{7} \mathrm{Ge}_{12}, \mathrm{LiGe}, \mathrm{Li}_{11} \mathrm{Ge}_{6}, \mathrm{Li}_{9} \mathrm{Ge}_{4}, \mathrm{Li}_{7} \mathrm{Ge}_{2}, \mathrm{Li}_{15} \mathrm{Ge}_{4}$, and $\mathrm{Li}_{22} \mathrm{Ge}_{5}$ [138]. In addition, the dilatation/contraction of the lattice upon lithiation/delithiation is isotropic ( $260 \%$ volume change) so that the particles avoid cracking even at a high C-rate and big particles $620 \mathrm{~nm}$ in size, which result in remarkable rate capability of Ge [139]. However, Ge has a disadvantage with respect to Si: A much higher cost of production. For a recent review on Ge-nanomaterials as anodes for LIBs, see Ref. [140,141].

Since 2012, improvements on Ge anodes have been made by the fabrication of hybrids with graphene oxide using different synthesis routes. Xue et al. [142] proposed a double carbon protection strategy, in which Ge is combined with amorphous carbon and graphene. When cycled under the high current density of $3.6 \mathrm{~mA} \mathrm{~g}^{-1}$, the Ge@C/rGO nanocomposites still displayed a specific capacity of $380 \mathrm{mAh} \mathrm{g}^{-1}$ after 50 cycles, which is still higher than the specific capacity of $100 \mathrm{mAh} \mathrm{g}^{-1}$ of Ge@C NPs hybrid. Later, another Ge@C/rGO composite was fabricated by simply distributing Ge@C on the rGO sheets using a low-pressure thermal deposition approach. Such a hybrid anode exhibited a reversible capacity of $\sim 940 \mathrm{mAh} \mathrm{g}^{-1}$ at a current density of $50 \mathrm{~mA} \mathrm{~g}^{-1}$ after 50 cycles. Germanium-graphene composites retained a capacity of $675 \mathrm{mAh} \mathrm{g}^{-1}$ after 400 cycles at current density to $400 \mathrm{~mA} \mathrm{~g}^{-1}$ [31]. Later, $\mathrm{Xu}$ et al. [143] reported the fabrication of a Ge/rGO composite made of $\sim 5 \mathrm{~nm}$ Ge nanoparticles uniformly distributed within a nitrogen-doped rGO carbon matrix using a PVP-assisted hydrolysis method. The Ge/rGO composite delivered an initial discharge capacity of $1475 \mathrm{mAh} \mathrm{g}^{-1}$ and a reversible capacity of $700 \mathrm{mAh} \mathrm{g}^{-1}$ after 200 cycles at a current density of $0.5 \mathrm{~A} \mathrm{~g}^{-1}$, which demonstrates that the conductive rGO carbon matrix alleviated the pulverization problem, prevented Ge particle aggregation, and facilitated lithium-ion motion. Wang et al. [144] prepared Ge@C/rGO hybrids as anode materials for Li-ion batteries by anchoring the core-shell structured germanium@carbon (Ge@C) on the reduced graphene oxide nanosheets by the strong adhesion of polydopamine (PDA). The products delivered a reversible capacity of $1074 \mathrm{mAh} \mathrm{g}^{-1}$ at $2 \mathrm{C}$ rate after 600 cycles (capacity retention of $96.5 \%$ ) and $436 \mathrm{mAh} \mathrm{g}^{-1}$ at 20C rate after 200 cycles. An advanced anode material, which consists of sub-micron Ge crystals (200-600 nm) uniformly encapsulated in a conductive rGO matrix forming a sandwich-structured $\mathrm{rGO} / \mathrm{Ge} / \mathrm{rGO}$, was successfully prepared through a facile thermal reduction method [145]. Enhanced reversible specific capacity of $1085 \mathrm{mAh} \mathrm{g}^{-1}$ was delivered after 500 cycles at current density of $1.6 \mathrm{~A} \mathrm{~g}^{-1}$ (1C rate) with the capacity loss of $\sim 0.017 \%$ per cycle. This $\mathrm{rGO} / \mathrm{Ge} / \mathrm{rGO}$ 
anode was tested in a coin-type full cell with $\mathrm{LiNi}_{0.5} \mathrm{Co}_{0.2} \mathrm{Mn}_{0.3} \mathrm{O}_{2}$ as cathode, which exhibited a high specific capacity of $940 \mathrm{mAh} \mathrm{g}^{-1}$ after 100 cycles at $1 \mathrm{C}$ rate. Fang et al. [146] compared the performance of two Ge-based hybrids, namely Ge-rGO and Ge-rGO-CNTs. Ge nanoparticles anchored on rGO intertwined with carbon nanotubes (CNTs) yielded a capacity of $863 \mathrm{mAh} \mathrm{g}^{-1}$ at a current density of $100 \mathrm{~mA} \mathrm{~g}^{-1}$ after 100 cycles and good rate performance of 1181, 1073, 1005, 872, 767, and $644 \mathrm{mAh} \mathrm{g}^{-1}$ at current densities of $100,200,400,800,1600$, and $3200 \mathrm{~mA} \mathrm{~g}^{-1}$, respectively. As an example, Figure 4 presents the electrochemical performance of pure Ge, Ge-rGO, and Ge-rGO-CNTs nano-composite anodes.
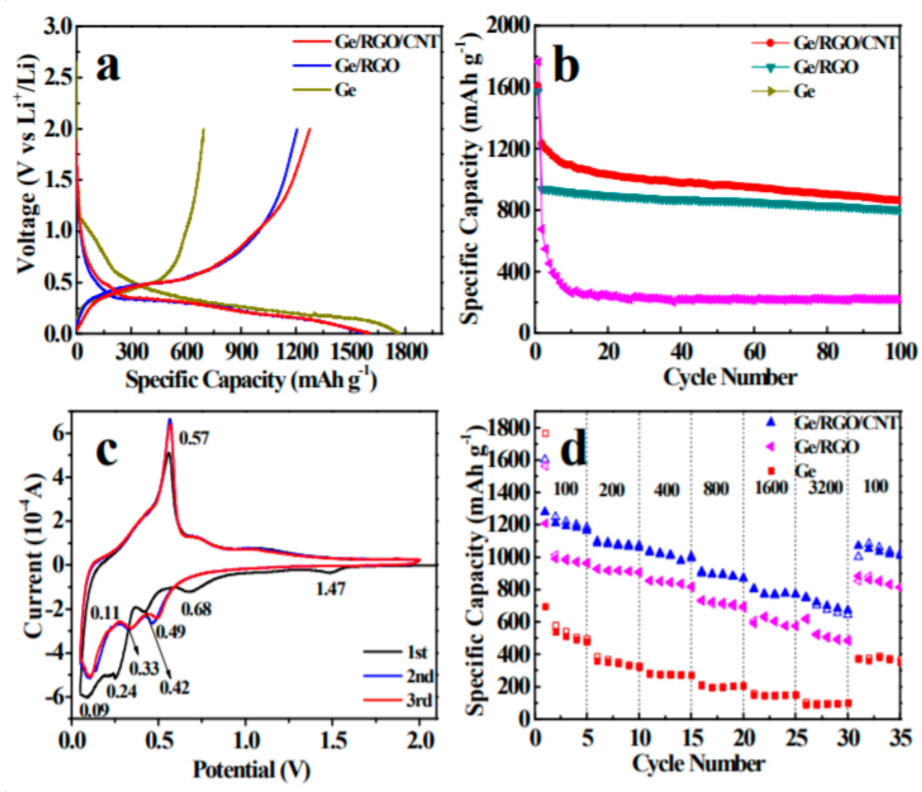

Figure 4. (a) Charge/discharge curves of pure $\mathrm{Ge}, \mathrm{Ge} / \mathrm{rGO}$, and $\mathrm{Ge} / \mathrm{rGO} /$ carbon nanotubes (CNTs) nanocomposite at a rate of $0.1 \mathrm{~A} \mathrm{~g}^{-1}$. (b) Cycling performance of the three different samples at a current density of $0.1 \mathrm{~mA} \mathrm{~g}^{-1}$. (c) Cyclic voltammetry curves of $\mathrm{Ge} / \mathrm{rGO} / \mathrm{CNTs}$ between 2.0 and $0.05 \mathrm{~V}$ with a scan rate of $0.1 \mathrm{mV} \mathrm{s}^{-1}$. (d) Rate performance of pure Ge, Ge/rGO and Ge/rGO/CNTs nanocomposite electrodes at different current rates. Reproduced with permission from [146]. Copyright 2015 The Royal Society of Chemistry.

Recently, Chen and coworkers [147] proposed an in-situ method (i.e., chemical reaction at $60{ }^{\circ} \mathrm{C}$ for $3 \mathrm{~h}$ of a mixture of $\mathrm{GO}$ suspension and $\mathrm{Na}_{2} \mathrm{GeO}_{3}$ aqueous solution added with $\mathrm{NaBH}_{4}$ solution) for the synthesis of amorphous Ge/rGO nanocomposites containing 27-37 wt\% carbon, which were transformed to crystalline phase by annealing at $650{ }^{\circ} \mathrm{C}$ in reducing $\mathrm{Ar} / \mathrm{H}_{2}$ atmosphere. The mesoporous $\mathrm{Ge} / \mathrm{rGO}$ hybrid $\left(34.3 \mathrm{wt} \% \mathrm{C}\right.$ ) had a BET specific surface area and average pore size of $81 \mathrm{~m}^{2} \mathrm{~g}^{-1}$ and $4.2 \mathrm{~nm}$, respectively. Galvanostatic measurements carried out at the current density of $0.1 \mathrm{~A} \mathrm{~g}^{-1}$ in the potential range of $0.01-1.5 \mathrm{~V}$ vs. $\mathrm{Li}^{+/} \mathrm{Li}$ ) showed initial discharge and charge specific capacities of 2100 and $1184 \mathrm{mAh} \mathrm{g}^{-1}$ (ICE of 56.4\%) and cycling performance of $500 \mathrm{mAh} \mathrm{g}^{-1}$ is obtained at $5 \mathrm{~A} \mathrm{~g}^{-1}$ current rate after 100 cycles. It is believed that the small size $(\sim 5 \mathrm{~nm})$ of Ge nanoparticles embedded in rGO sheets results in void space large enough to buffer the volume and maintain high structural stability during cycles. The full cell Ge/rGO\|LiFePO ${ }_{4}$ performed the specific capacity of $\sim 125 \mathrm{mAh} \mathrm{g}^{-1}$ at $0.5 \mathrm{C}\left(85 \mathrm{~mA} \mathrm{~g}^{-1}\right)$ over 100 cycles. Zhao et al. [148] designed a double-layered protective structure in which the cubic hollow Ge@C hybrids are uniformly dispersed on rGO through dopamine-coating and subsequent carbothermal reduction. The Ge@C/rGO composite demonstrated the capacity of $1183 \mathrm{mAh} \cdot \mathrm{g}^{-1}$ at the specific current of $0.1 \mathrm{~A} \mathrm{~g}^{-1}$ and $710 \mathrm{mAh} \mathrm{g}^{-1}$ at $1 \mathrm{~A} \mathrm{~g}^{-1}$ for 200 cycles. A few-layer methyl-terminated germanene-graphene nanocomposite $\left(\mathrm{GeCH}_{3} / \mathrm{rGO}\right)$ was prepared through ultrasonic wet dispersion using $\mathrm{GeCH}_{3}$ nanosheets (typical thickness $4-5 \mathrm{~nm}$ ) prepared by liquid-phase exfoliation [149]. The resulting $\mathrm{GeCH}_{3} / \mathrm{rGO}|| \mathrm{Li}$ half-cell exhibited a remaining capacity 
of $1058 \mathrm{mAh} \mathrm{g}^{-1}$ after 100 cycles at $0.2 \mathrm{~A} \mathrm{~g}^{-1}$ with CE of $98 \%$. After 500 cycles the capacities were 439 and $288 \mathrm{mAh} \mathrm{g}^{-1}$ (CE of 98.58 and $99.31 \%$ ) at current densities of 0.5 and $1.0 \mathrm{~A} \mathrm{~g}^{-1}$, respectively. Electrochemical performance of $\mathrm{Ge} / \mathrm{rGO}$ composite anodes from the recent literature are summarized in Table 2.

Table 2. Summary of electrochemical properties of Ge-based composite anodes. Relevant cycle number is given in brackets.

\begin{tabular}{|c|c|c|c|c|}
\hline Material & Synthesis & $\begin{array}{c}\text { Specific Capacity } \\
\left(\mathrm{mAh} / \mathrm{g}^{-1}\right)\end{array}$ & $\begin{array}{l}\text { Current Density } \\
\left(\mathrm{A} / \mathrm{g}^{-1}\right)\end{array}$ & Ref. \\
\hline Ge@C/rGO & polymerization with PDA & 1074 & $3.2(600)$ & [144] \\
\hline Ge@C/rGO & dispersion + thermal reduction & 380 & $0.1(50)$ & [142] \\
\hline Ge@C/rGO & low-pressure thermal deposition & 940 & $0.05(50)$ & [31] \\
\hline Ge-rGO-CNTs & dispersion + thermal reduction & 863 & $0.1(100)$ & [146] \\
\hline $\mathrm{Ge} / \mathrm{rGO}$ & PVP-assisted hydrolysis & 700 & $0.5(200)$ & [143] \\
\hline $\mathrm{rGO} / \mathrm{Ge} / \mathrm{rGO}$ & carbothermal reduction & 1085 & $1.6(500)$ & [145] \\
\hline Ge@C/rGO & carbothermal reduction & 710 & $1.0(200)$ & [148] \\
\hline $\mathrm{Ge} / \mathrm{rGO}$ & polymeric in-situ reduction & 960 & $1.0(100)$ & [147] \\
\hline $\mathrm{GeCH}_{3} / \mathrm{rGO}$ & ultrasonic wet dispersion & 1058 & $0.2(100)$ & [149] \\
\hline $\mathrm{CuGeO}_{3} / \mathrm{rGO}(30 \mathrm{wt} \%)$ & hydrothermal reduction & 909 & $0.1(200)$ & [150] \\
\hline
\end{tabular}

\subsection{Tin}

Wen and Huggins showed that tin reacted with lithium to generate different alloys within the Li-Sn phase diagram [151]. Therefore, Sn has attracted great attention as anode material due to its low cost and good electrochemical activity. Upon lithiation, Sn exhibits a theoretical reversible capacity of $994 \mathrm{mAh} \mathrm{g}^{-1}$ according the reaction $\mathrm{Sn}+x \mathrm{Li}^{+}+x \mathrm{e}^{-} \leftrightarrow \mathrm{Li}_{x} \mathrm{Sn}(0 \leq x \leq 4.4)$ with a working potential of $\sim 0.5 \mathrm{~V}$ vs. $\mathrm{Li}^{+/} \mathrm{Li}[152,153]$. However, during the battery cycles, $\mathrm{Sn}$ anodes seriously suffer from repeated large compressive and tensile stresses, which leads to fast capacity fading [154]. This problem can be solved by using Sn-graphene composites. In the early 2000s, Li and coworkers [155] investigated several nano-alloy anodes for lithium-ion batteries and showed that, with the pure nanostructured phase $\beta$-Sn-Sb prepared by co-precipitation, the reversible alloy reaction of $\mathrm{Li}$ with $\mathrm{Sb}(2)$ and $\mathrm{Sn}(3)$ occurs at $0.9-0.7$ and $0.7-0.0 \mathrm{~V}$ successively. However, the use of this anode material is limited because $\mathrm{Li}$ alloy clusters have a very strong tendency to aggregate and form larger nano-crystallites $(>20 \mathrm{~nm})$ inducing a decrease of the surface energy of nano-alloy particles/clusters. In 2012, Wang et al. [156] outlined the development of Sn-based nanomaterials with a focus on their dimensionality when combined with different types of carbonaceous materials (i.e., carbon supported and carbon confined) as anode composites in LIBs. Sn/graphene composites grown by in-situ chemical reduction process (using $\mathrm{GO}$ and $\mathrm{SnCl}_{2}$ precursors) exhibited lithium storage performance of $795 \mathrm{mAh} \mathrm{g}^{-1}$ in the 2nd cycle and $508 \mathrm{mAh} \mathrm{g}^{-1}$ in the 100th cycle, much better than that of bare Sn nanoparticles [157]. Hybridized 1D Sn nanoparticles were integrated onto the rGO surface via a hydrolysis process to form rGO-supported Sn/C nanocales (rGO/Sn@C) [158]. These rGO/Sn@C coaxial nanocables displayed an initial capacity of $760 \mathrm{mAh} \mathrm{g}^{-1}$ with a retention of $83 \%$ after 50 cycles. Submicron metallic Sn particles encapsulated in a rGO framework were used as the electrode materials for potassium-ion batteries. The Sn@rGO anode, with abundant structural defects and a high BET surface area of $136.5 \mathrm{~m}^{2} \mathrm{~g}^{-1}$, exhibited a capacity of $120 \mathrm{mAh} \mathrm{g}^{-1}$ after 500 cycles at $0.5 \mathrm{Ag}^{-1}$ and an excellent rate capability of $67 \mathrm{mAh} \mathrm{g}^{-1}$ at $2 \mathrm{~A} \mathrm{~g}^{-1}$ [159]. Botas et al. developed an advanced binder-free anode material composed of 3D macroporous foams formed by rGO and submicron tin-based particles [160]. Typically, Sn/rGO samples were obtained by preparing a Sn-rGO aerogel by dissolving $\mathrm{SnSO}_{4}$ in a $\mathrm{GO}$ suspension, with a control at $\mathrm{pH}=9$ by addition of $\mathrm{NH}_{3}$ solution, followed by a pyrolysis process at $800^{\circ} \mathrm{C}$ in argon atmosphere. The $\mathrm{Sn} / \mathrm{rGO}$ anode delivered an initial capacity of $715 \mathrm{mAh} \mathrm{g}^{-1}$, decreasing to $234 \mathrm{mAh} \mathrm{g}^{-1}$ after 50 cycles at $50 \mathrm{~mA} \mathrm{~g}^{-1}$.

Two other metal/carbon would be worthy to be mentioned. A Ni@C composite, which consists of dispersed Ni nanocrystals (average size of $20 \mathrm{~nm}$ ) encapsulated by carbon nanosheets was prepared via 
thermal decomposition of a nickel oleate complex at $700{ }^{\circ} \mathrm{C}$. The composite adopts a bending structure with a good ordering of the carbon layers, forced by the Ni encapsulation. The electrode delivers an average capacity value around $723 \mathrm{mAh} \cdot \mathrm{g}^{-1}$ on cycling at moderate rate of $\mathrm{C} / 4$. At higher rate (1C), the average specific capacity decreases to $\sim 205 \mathrm{mAh} \cdot \mathrm{g}^{-1}$ with a coulombic efficiency close to $100 \%$ after the first cycles [161]. To overcome the capacity fading of the antimony anode (theoretical capacity of $660 \mathrm{mAh} \mathrm{g}^{-1}$, volumetric strain of $135 \%$ ), a Sb/rGO anode was prepared by poly(acrylic acid) and nickel nitrate assisted electrophoretic deposition. The composite anode deposited on copper foil offers a stable discharge and charge capacity of $\sim 498$ and $\sim 498 \mathrm{mAh} \mathrm{g}^{-1}$, respectively, up to 100 cycles at a high current rate of $0.5 \mathrm{~A} \mathrm{~g}^{-1}$ [162].

\section{Metal Oxide/rGO Composites}

\subsection{Silicon-Based Oxide Composites}

Silica suboxides $\left(\mathrm{SiO}_{\mathrm{x}}\right)$ have been regularly studied as hopeful anode materials replacing pure $\mathrm{Si}$. In 2002, the Yamamoto group demonstrated the effect of both the oxygen concentration and particle size on the cycling life and on the reversible capacity of $\mathrm{SiO}_{x}$ [163]. In 2012, the Sohn group found that $\mathrm{SiO}_{2}$ could be activated via a simple high-energy ball-milling process and could deliver a reversible capacity of $\sim 800 \mathrm{mAh} \mathrm{g}^{-1}$ after 200 cycles [164]. The lithium battery with $\mathrm{SiO}_{0.8}$ anode (50 nm particle size) can provide a reversible capacity of ca. $1600 \mathrm{mAh} \mathrm{g}^{-1}$ over the voltage range from 0.02 to $1.4 \mathrm{~V}$ vs. $\mathrm{Li}^{+} / \mathrm{Li}$. The success of $\mathrm{SiO}_{\mathrm{x}}$ materials is due to their high theoretical capacity $\left(>1600 \mathrm{mAh} \mathrm{g}^{-1}\right)$ and to the lithium oxygen co-ordination, which implies minimal volume change and, at the same time, lower activation energy [165].

$\mathrm{SiO}_{\mathrm{x}}$-based composites were synthesized by green methods such as hydrothermal route [166,167], chemical etching [168], sol-gel with subsequent annealing [169,170], solvothermal reaction [171], template route [172], and vacuum-assisted filtration and self-assembling [173,174]. Haeri et al. [169] synthesized $\mathrm{SiO}_{2} / \mathrm{GO}$ nanohybrids through one-step sol-gel method using a mixture of tetraethylorthosilane (TEOS) and 3-aminopropyl triethoxysilane (APTES) silanes at various hydrolysis times. Structural analysis showed that amino-functionalized $\mathrm{SiO}_{2}$ nanoparticles $(\sim 20-30 \mathrm{~nm})$ were deposited on the basal plane of GO sheets. Kasimayan et al. [168] used the same method for the preparation of $\mathrm{SiO}_{2} @ \alpha-\mathrm{Fe}_{2} \mathrm{O}_{3}$ core-shell decorated rGO nanocomposites with a subsequent refluxing process at $75^{\circ} \mathrm{C}$ for $6 \mathrm{~h}$.

Guo et al. [175] designed a $\mathrm{SiO}_{x} / \mathrm{C} / \mathrm{rGO}$ ternary nanocomposite using tetraethoxysilane (TEOS) as the silicon precursor. The primary $\mathrm{SiO}_{\mathrm{x}} / \mathrm{C}$ nanoparticles (spherical shape 50-100 nm diameter) were $\mathrm{SiO}_{\mathrm{x}}$ particles coated with a 3-nm thick carbon layer; the disorderly stacked layer-by-layer $\mathrm{SiO}_{\mathrm{x}} / \mathrm{C} / \mathrm{rGO}$ structure containing $20 \mathrm{wt} \%$ of amorphous carbon and $\mathrm{rGO}$ obtained by solvothermal reaction demonstrated very high BET specific surface area of $390.2 \mathrm{~m}^{2} \mathrm{~g}^{-1}$. Tested at $100 \mathrm{~mA} \mathrm{~g} \mathrm{~g}^{-1}$ between 0.01 and $1.5 \mathrm{~V}$, it exhibited a capacity of $1284 \mathrm{mAh} \mathrm{g}^{-1}$ after 100 cycles. At high rate of $3.2 \mathrm{~A} \mathrm{~g}^{-1}$, the electrode retained $412 \mathrm{mAh} \mathrm{g}^{-1}$. The electric conductivity of the $\mathrm{SiO}_{\mathrm{x}} / \mathrm{C} / \mathrm{RGO}$ was $1.26 \times 10^{-3} \mathrm{~S} \mathrm{~cm}^{-1}$. $\mathrm{Xu}$ et al. [166] fabricated a hierarchical structure $\mathrm{SiO}_{2} @ \mathrm{SnO}_{2} / \mathrm{rGO}$ by a facile hydrothermal process, which consisted of mono-dispersed $\mathrm{SnO}_{2}$ nanoparticles (as small as $5 \mathrm{~nm}$ ) on the surface of rGO sheets and $\mathrm{SiO}_{2}$ spheres ( $\left.100 \mathrm{~nm}\right)$. The $\mathrm{SiO}_{2} @ \mathrm{SnO}_{2} / \mathrm{rGO}$ electrode displayed a large initial discharge capacity of $1548 \mathrm{mAh} \mathrm{g}^{-1}$ at a current density of $100 \mathrm{~mA} \mathrm{~g}^{-1}$ and it still retained a discharge capacity of about $600 \mathrm{mAh} \mathrm{g}^{-1}$ after 100 cycles. In this hybrid, the presence of $\mathrm{SiO}_{2}$ nanospheres mitigated the agglomeration tendency of $\mathrm{SnO}_{2}$ nanoparticles. Zhao et al. [167] reported ternary $\mathrm{Co}_{2} \mathrm{SiO}_{4} / \mathrm{SiO}_{2} / \mathrm{RGO}$ nanocomposites that exhibited a reversible capacity of $1382 \mathrm{mAh} \mathrm{g}^{-1}$ at $0.5 \mathrm{~A} \mathrm{~g}^{-1}$ current rate and long-life span ( 500 cycles), which is over 20 times higher than the $\mathrm{SiO}_{2} / \mathrm{rGO}$ counterpart. Ex situ XPS measurements evidenced the role $\mathrm{Co}$, which activates and promotes the conversion of tetravalent state of Si to low valence ones along with cycling. Guo et al. [176] reported the lithium storage performance of $\mathrm{SiO}_{2} @ \mathrm{rGO}$ hybrid, which consists of 3D interconnected $\mathrm{SiO}_{2}$ nanoparticles ( $<120 \mathrm{~nm}$ in diameter) coated by rGO. This composite was fabricated by online hydrolysis and subsequent condensation of 
the precursor tetraethylorthosilicate (TEOS) in the dispersed GO sol, followed by the reduction of GO using hydrazine hydrate. The $\mathrm{SiO}_{2} @ \mathrm{rGO}$ anode material delivered a reversible discharge capacity of $708 \mathrm{mAh} \mathrm{g}^{-1}$ for the 2nd cycle and $490 \mathrm{mAh} \mathrm{g}^{-1}$ at a current density of $100 \mathrm{~mA} \mathrm{~g}^{-1}$ after 60 cycles with CE of $\sim 98 \%$.

More recently, Hu et al. [168] developed a composite with core-shell $\mathrm{Fe}_{3} \mathrm{O}_{4} @ \mathrm{SiO}_{2}$ particles wrapped by rGO nanosheets. Meso-/micro-porosity was produced by chemical etching, forming 3D continuous channels for $\mathrm{Li}^{+}$motion. The $\mathrm{Fe}_{3} \mathrm{O}_{4} @ \mathrm{SiO}_{2} / \mathrm{GO}$ composite delivered an initial specific capacity of $1630 \mathrm{mAh} \mathrm{g}^{-1}$ at $0.1 \mathrm{Ag}^{-1}$ rate over the potential range of $0.01-3.0 \mathrm{~V} \mathrm{vs}^{-\mathrm{Li}^{+/}} \mathrm{Li}$ along with a $\mathrm{CE}$ of $86 \%$ and retained the capacity of $514 \mathrm{mAh} \mathrm{g}^{-1}$ at $5 \mathrm{~A} \mathrm{~g}^{-1}$ after 1000 cycles. The fast charge/discharge process was

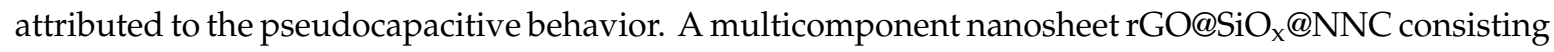
of an inner $\mathrm{rGO}$ nanosheet substrate, an $\mathrm{SiO}_{\mathrm{x}}$ intermediate layer, and an $\mathrm{N}$-doped nanoporous carbon

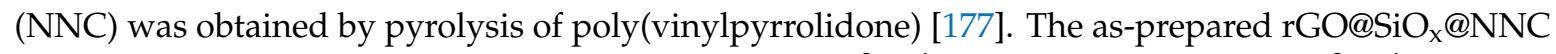
nanosheets with a high BET specific surface area of $360 \mathrm{~m}^{2} \mathrm{~g}^{-1}$ and pore volume of $0.6 \mathrm{~cm}^{3} \mathrm{~g}^{-1}$ exhibited a good cycle ability of $410 \mathrm{mAh} \mathrm{g}^{-1}$ at a current density of $1 \mathrm{~A} \mathrm{~g}^{-1}$ for 200 cycles as well as a specific capacity of $179 \mathrm{mAh} \mathrm{g}^{-1}$ at $5 \mathrm{~A} \mathrm{~g}^{-1}$ after 500 cycles. The beneficial advantage of non-stoichiometric

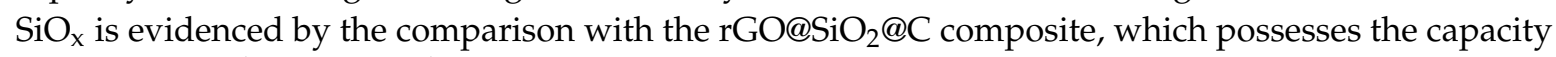
of $320 \mathrm{mAh} \mathrm{g}^{-1}$ at $1.0 \mathrm{~A} \mathrm{~g}^{-1}$ after 200 cycles (Figure 5).

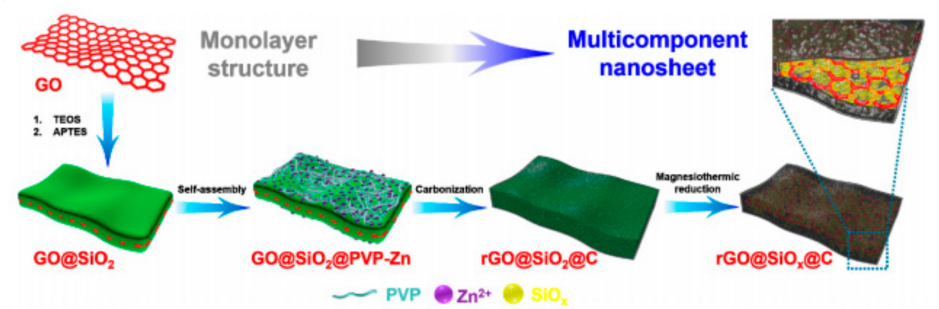

(A)
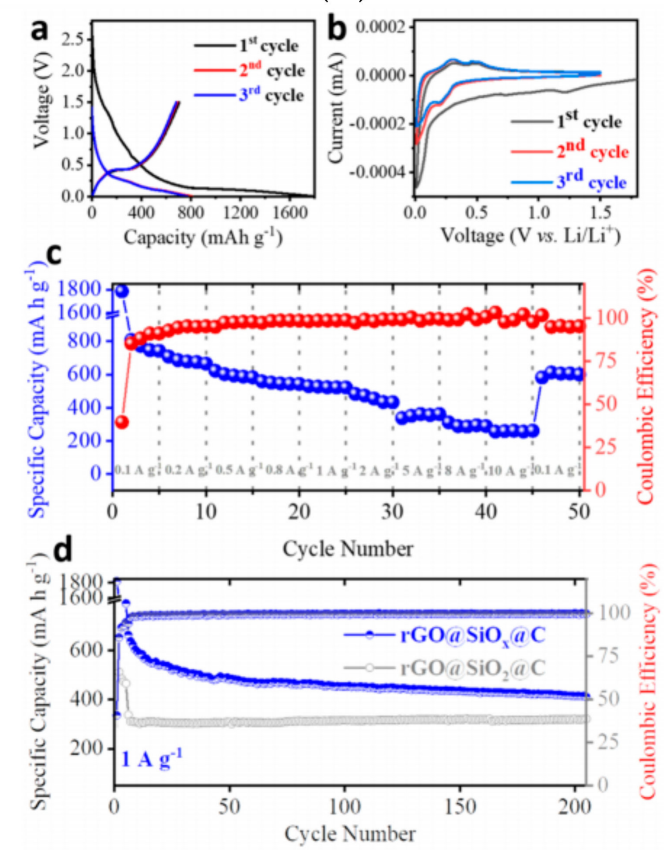

(B)

Figure 5. (A) Schematic illustration to fabricate $\mathrm{rGO} @ S i O_{\mathrm{x}} @ \mathrm{C}$ nanosheets. (B) Electrochemical properties: (a) Discharge-charge curves at $0.1 \mathrm{~A} \mathrm{~g}^{-1}$, (b) cyclic voltammetry (CV) curves at $0.1 \mathrm{mV} \mathrm{s}^{-1}$

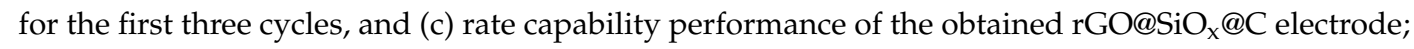
(d) coulombic efficiency (CE) and cycling stability at a current density of $1 \mathrm{~A} \mathrm{~g}^{-1}$ for 200 cycles of rGO@ $\mathrm{SiO}_{2} @ \mathrm{C}$ and $\mathrm{rGO} @ S_{\mathrm{SiO}} @ \mathrm{C}$. Reproduced with permission from [177]. Copyright 2020 American Chemical Society. 


\subsection{Tin-Based Oxide Composites}

$\mathrm{SnO}_{2}$ has been widely investigated as anode for Li-ion batteries. It is abundant in nature, environmentally friendly, and has the advantage of high theoretical capacity (782 $\left.\mathrm{mAh} \mathrm{g}^{-1}\right)$. In 1997, Idota et al. from Fuji Photo Film Company (Japan) replaced the graphite anode of Li-ion cells by a tin-based amorphous composite oxide (TCO), which can accept 8 moles of $\mathrm{Li}^{+}$ions per unit mole [178]. Based on previous findings, the lithiation of $\mathrm{SnO}_{2}$ occurs within three steps: Insertion (intermediate phase), conversion, and alloying/dealloying [179]. However, the poor electrical conductivity of $\mathrm{SnO}_{2}$ and its severe volume expansion during lithiation hinder its wide scale utilization. Thus, the extensive study of $\mathrm{SnO}_{2}$-graphene composites started in 2010-2011; the integration of $\mathrm{SnO}_{2}$ with graphene has demonstrated improvement in cycling stability and rate capability [180-184].

Currently, $\mathrm{SnO}_{2}$ /graphene hybrids are fabricated using tin salts and GO via different routes, such as chemical reduction, hydrothermal growth, in situ deposition, and combined routes including calcination as the last step [25,185-190]. The most explored strategy used for the fabrication of $\mathrm{SnO}_{2} / \mathrm{rGO}$ composite involves the hydro- or solvo-thermal deposition of very small $\mathrm{SnO}_{2}$ nanoparticles (generally $\sim 5 \mathrm{~nm}$ ) on the GO layers [186,191] and its subsequent partial reduction by thermal treatments at moderate temperatures under inert atmosphere [192] or through its reaction with hydrazine [193]. For example, Hu et al. [194] designed and prepared a 3D porous $\mathrm{rGO}$ wrapped hollow $\mathrm{SnO}_{2}$ nanosphere composite via a hydrothermal reaction and hydrazine reduction process. The as-developed 3D porous $\mathrm{H}-\mathrm{SnO}_{2} / \mathrm{rGO}$ composite was tested as anode showing a high reversible capacity of $1107 \mathrm{mAh} \mathrm{g}^{-1}$ after 100 cycles at a current density of $0.1 \mathrm{~A} \mathrm{~g}^{-1}$ and maintaining $552 \mathrm{mAh} \mathrm{g}^{-1}$ over 500 cycles at a current density up to $1 \mathrm{~A} \mathrm{~g}^{-1}$. $\mathrm{SnO}_{2} \mathrm{NCs} @ \mathrm{~N}-\mathrm{rGO}$ hybrid anode material was fabricated by binding $\mathrm{SnO}_{2}$ nanocrystals (NCs) in N-doped rGO sheets by means of an in-situ hydrazine monohydrate vapor reduction method [193]. It is believed that bonds formed between graphene and $\mathrm{SnO}_{2} \mathrm{NCs}$ limit the aggregation of in situ formed Sn nanoparticles, leading to a stable hybrid anode material with long cycle life. A simple one-pot hydrothermal method was utilized by Wang and coworkers [195] to prepare tungsten-doped $\mathrm{SnO}_{2}$ and reduced graphene oxide nanocomposites. The $\mathrm{W}: \mathrm{SnO}_{2} / \mathrm{rGO}_{\text {hybrid }}$ exhibited an excellent long-term cycling performance. After 100 cycles, the specific discharge capacity was still as high as $1100 \mathrm{mAh} \mathrm{g}^{-1}$ at $0.1 \mathrm{~A} \mathrm{~g}^{-1}$ current rate (i.e., capacity retention of 90\%). It still remained at $776 \mathrm{mAh} \mathrm{g}^{-1}$ after 2000 cycles at the current density of $1 \mathrm{~A} \mathrm{~g}^{-1}$. Wang et al. [196] prepared defect-rich crystalline $\mathrm{SnO}_{2}$ nanoparticles with an average size of $3.5 \mathrm{~nm}$ homogeneously deposited on

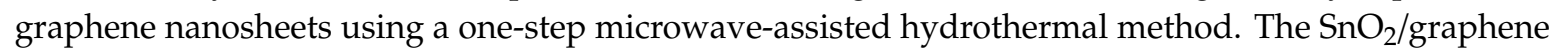
nanocomposites deliver a superior reversible capacity of $635 \mathrm{mAh} \mathrm{g}^{-1}$ after 100 cycles and display excellent rate performance. Shao and coworkers [197] prepared a $\mathrm{SnO}_{2} / \mathrm{rGO}$ composite with $\mathrm{SnO}_{2}$ nanoparticles confined by multilayered and interconnected 3D spherical rGO sheets; such hybrid anode displayed a large reversible capacity over $1000 \mathrm{mAh} \mathrm{g}^{-1}$ and long cycling life with $88 \%$ retention after 100 cycles. In situ chemical synthesis of $\mathrm{SnO}_{2} / \mathrm{rGO}$ nanocomposites $\left(\mathrm{SnO}_{2}\right.$ crystal size of $\left.\sim 3-4 \mathrm{~nm}\right)$ was realized in ethanol solution. This anode material had a reversible lithium storage capacity of $1051 \mathrm{mAh} \mathrm{g}^{-1}$ [198]. Hierarchical porous $\mathrm{SnO}_{2}$ incorporated with $\mathrm{rGO}\left(\mathrm{HP}-\mathrm{SnO}_{2} / \mathrm{rGO}\right)$ was fabricated by Chen and coworkers [199] showing mesopores of $3.3 \mathrm{~nm}$ and macropores of $\sim 200 \mathrm{~nm}$. The half-cell using $\mathrm{Li} \| \mathrm{SnO}_{2} / \mathrm{rGO}$ exhibited an excellent cycle performance of $850 \mathrm{mAh} \mathrm{g}^{-1}$ in 100 cycles at a current density of $0.3 \mathrm{C}$ and rate capability of $436 \mathrm{mAh} \mathrm{g}^{-1}$ at a current density of $4.5 \mathrm{C}$. The GO/SnO 2 nanocomposite was prepared using an aqueous solution of $\mathrm{Sn}\left(\mathrm{BF}_{4}\right)_{2}$ with the addition of $\mathrm{GO}$ powders and different concentrations of reducing agent (i.e., $0-0.075 \mathrm{~mol} \mathrm{~L}^{-1} \mathrm{Na}_{2} \mathrm{~S}_{2} \mathrm{O}_{4}+0.5 \mathrm{~mol} \mathrm{~L}^{-1} \mathrm{HBF}_{4}$ ) [200]. Using low content of reducing agent (0.025 mole), the $\mathrm{rGO}-\mathrm{SnO}_{2}$ hybrid obtained by annealing at $500{ }^{\circ} \mathrm{C}$ under Ar atmosphere for $2 \mathrm{~h}$ exhibited $\mathrm{SnO}_{2}$ nanoparticles of 15-20 nm in size and rGO Raman spectrum with $I_{\mathrm{D}} / I_{\mathrm{G}}$ ratio of $\sim 1.06 \pm 0.01$. It showed good Li storage performance with specific capacity of $378 \mathrm{mAh} \mathrm{g}^{-1}$ at $3.2 \mathrm{~A} \mathrm{~g}^{-1}$, and cyclability of $522 \mathrm{mAh} \mathrm{g}^{-1}$ after 50 cycles at $30 \mathrm{~mA} \mathrm{~g}^{-1}$ current rate.

Since 2019, advanced rGO-based anodes have shown remarkable performance. Tan et al. [201] have used combined methods including in-situ metal tin oxidation for the generation of the $2 \mathrm{D} \mathrm{Sn} / \mathrm{SnO} / \mathrm{SnO} 2$ structure, and spray drying and thermal annealing for the transformation to 3D blueberry-shaped 
$\mathrm{SnO}_{2} / \mathrm{rGO}$. The as-prepared hybrid containing $18.6 \mathrm{wt} \% \mathrm{rGO}$ displayed a BET surface area of $218 \mathrm{~m}^{2} \mathrm{~g}^{-1}$. Tested under a current density of $500 \mathrm{~mA} \cdot \mathrm{g}^{-1}$ in the potential window $0.01-3.0 \mathrm{~V}$ it exhibited a reversible capacity of $708 \mathrm{mAh} \cdot \mathrm{g}^{-1}$ over 150 cycles. Liu et al. [202] have developed an $\mathrm{SnO}_{2} / \mathrm{GO}$ composite composed of $\mathrm{SnO}_{2}$ nanoparticles (200 nm in size) uniformly anchored on the surface of GO sheets using ultrasonication and calcination processes. The anode with $\mathrm{SnO}_{2}$ : GO ratio of 4:1 exhibits a discharge capacity of $492 \mathrm{mAh} \mathrm{g}^{-1}$ at $0.2 \mathrm{C}$ rate after 100 cycles. Tan et al. [201] reported the properties of a shrunken 3D dried blueberry shaped $\mathrm{SnO}_{2} / \mathrm{rGO}$ composite synthesized by tin foil washed by sonification in anhydrous ethanol and placed in GO suspension in oil bath maintained at $90{ }^{\circ} \mathrm{C}$. The $\mathrm{SnO}_{2} / \mathrm{rGO}$ composite consisting of individual $\mathrm{SnO}_{2}$ crystals (10 $\mathrm{nm}$ in size) aggregated to form larger cluster $(100 \mathrm{~nm})$ were well encapsulated by the few-layered rGO sheets. Electrochemical tests of this anode electrode demonstrated a high initial capacity of 737 and $128 \mathrm{mAh} \cdot \mathrm{g}^{-1} \mathrm{under}$ a current density of 0.2 and $10.0 \mathrm{~A} \cdot \mathrm{g}^{-1}$, respectively, over 150 cycles, and a reversible capacity of $708 \mathrm{mAh} \cdot \mathrm{g}^{-1}$ under a current density of $0.5 \mathrm{~A} \cdot \mathrm{g}^{-1}$ over 150 cycles. Jiang et al. [203] developed a $\mathrm{SnO}_{2} / \mathrm{rGO}$ nanocomposite, which showed an initial specific capacity of $1705 \mathrm{mAh} \mathrm{g}^{-1}$ and a capacity retention of $500 \mathrm{mAh} \cdot \mathrm{g}^{-1}$ after 50 cycles at $250 \mathrm{~mA} \mathrm{~g}{ }^{-1}$. A free-standing $\mathrm{SnO}_{2} @ \mathrm{rGO}$ composite anode, in which $\mathrm{SnO}_{2}$ nanoparticles were tightly wrapped within wrinkled rGO sheets, was synthesized via an anti-solvent-assisted precipitation [204]. The $\mathrm{SnO}_{2} @ \mathrm{rGO}$ anode showed significant enhanced lithium storage behavior; a high charge capacity above $700 \mathrm{mAh} \mathrm{g}^{-1}$ was achieved with $95.6 \%$ retention after 50 cycles at a current density of $0.5 \mathrm{~A} \mathrm{~g}^{-1}$. The superior performance of the free-standing $\mathrm{SnO}_{2} @ \mathrm{rGO}$ electrode was evidenced by analysis of its structure after 50 cycles (Figure 6). Briefly, results are as follows: (i) The cycled composite anode displayed compressed pores and channels, attributed to the SEI formation during cycling, (ii) XRD pattern of the cycled anode revealed the co-existence of three $\mathrm{rGO}, \mathrm{SnO}_{2}$, and $\mathrm{Sn}$ components in the fully charged state, (iii) TEM image shows that, in the assembled composite, Sn-based nanoparticles remain uniformly wrapped within rGO sheets, and (iv) the observation of lattice fringes evidences the structural stability.

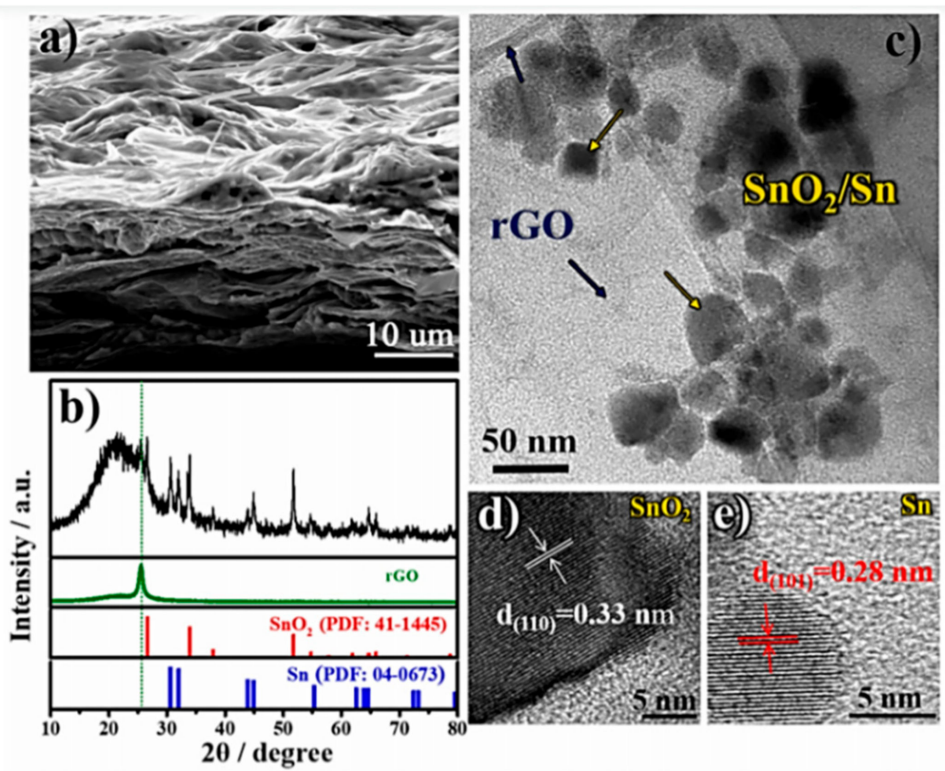

Figure 6. Morphologic and structural characteristics of cycled $\mathrm{SnO}_{2} @ \mathrm{rGO}$ nanocomposite synthesized via an anti-solvent-assisted precipitation method [204]. (a) FESEM image of the anode material in the fully charged state after 50 cycles at a current density of $0.5 \mathrm{~A} \mathrm{~g}^{-1}$, (b) XRD pattern, (c) TEM image, and HRTEM images of (d) $\mathrm{SnO}_{2}$ and (e) Sn particles, respectively. Copyright 2019 Jiang, Huang, Zhu, Li, Zhao, Gao, Gao, and Zhao. Under the terms of the Creative Commons Attribution License (CC BY).

Recently, $\mathrm{rGO}_{\mathrm{SnO}}(x=0,1,2)$ nanocomposites were prepared using a low-cost and room-temperature one-pot in-situ chemical reduction process for 30 min with $\mathrm{NaBH}_{4}(0 \mathrm{~mol}-0.06 \mathrm{~mol})$ 
as chelating agent [205]. $\mathrm{SnO}_{\mathrm{x}}$ nanoparticles $(2-4 \mathrm{~nm})$ were uniformly distributed over rGO sheets. The $\mathrm{rGO}^{-S n O} \mathrm{O}_{\mathrm{x}}$ hybrid synthesized by using $0.04 \mathrm{~mol} \mathrm{NaBH}_{4}$ revealed stable specific capacity of $833 \mathrm{mAh} \mathrm{g}^{-1}$ after 50 cycles, $767 \mathrm{mAh} \mathrm{g}^{-1}$ after 100 cycles at current rate of $0.1 \mathrm{~A} \mathrm{~g}^{-1}$, and good rate capability ( $481 \mathrm{mAh} \mathrm{g}^{-1}$ at $\sim 1 \mathrm{~A} \mathrm{~g}^{-1}$ ). The lithium-ion diffusion coefficient in the $\mathrm{rGO}^{-S n O} \mathrm{~S}_{\mathrm{x}}$ anode was estimated to be $2.4 \times 10^{-10} \mathrm{~m}^{2} \mathrm{~s}^{-1}$, which evidences the vital role of rGO in terms of kinetics.

Several reports have shown that doping also results in an increase of lithiation rate in $\mathrm{SnO}_{2}$. Wang et al. [206] compared the electrochemical behavior of an Fe-doped $\mathrm{SnO}_{2} / \mathrm{rGO}$ nanocomposite with undoped $\mathrm{SnO}_{2} / \mathrm{rGO}$ nanoparticles prepared through a wet-chemical approach. The specific capacity of the $\mathrm{SnO}_{2} / \mathrm{rGO}$ electrode $\left(\mathrm{SnO}_{2}\right.$ particle size of 6-8 nm) reaches $905 \mathrm{mAh} \mathrm{g}^{-1}$ after 100 cycles at $0.1 \mathrm{~A} \mathrm{~g}^{-1}$, while the $\mathrm{Fe} @ \mathrm{SnO}_{2} / \mathrm{rGO}$ nanocomposite retains a capacity of $1353 \mathrm{mAh} \mathrm{g}^{-1}$ in similar conditions. Huang et al. [207] fabricated a P-doped $\mathrm{SnO}_{2} / \mathrm{rGO} / \mathrm{C}$ composite by electrospinning process of a $\mathrm{GO} /\left(\mathrm{H}_{3} \mathrm{PO}_{4}\right) / \mathrm{SnCl}_{4} / \mathrm{PVP}$-containing precursor solution. The cycling performance is $285 \mathrm{mAh} \mathrm{g}^{-1}$ at a rate of $0.1 \mathrm{~A} \mathrm{~g}^{-1}$ after 60 cycles. Zoller et al. [208] investigated the Sb-doped $\mathrm{SnO}_{2}(\mathrm{ATO}) / \mathrm{rGO}$ composite synthesized via a microwave-assisted in-situ method in tert-butyl alcohol. This composite featured a specific capacity of $1226 \mathrm{mAh} \mathrm{g}^{-1}$ at $1 \mathrm{C}$ rate and retained $577 \mathrm{mAh} \mathrm{g}^{-1}$ at very high charge rate of $60 \mathrm{C}$. Fluorine-doped $\mathrm{SnO}_{2}$ was also realized through hydrothermal process, significantly improving the electrochemical properties of the $\mathrm{F}-\mathrm{SnO}_{2} \mathrm{NCs} / \mathrm{rGO}$ composite [209]. The composite delivers a reversible capacity of $1277 \mathrm{mAh} \mathrm{g}^{-1}$ after 100 cycles at current density $0.1 \mathrm{~A} \mathrm{~g}^{-1}$. The high-rate capability of $634 \mathrm{mAh} \mathrm{g}^{-1}$ after 10 cycles at current density $5 \mathrm{~A} \mathrm{~g}^{-1}$ was due to the reduced resistance induced by the F-doping that protects the electrode surface from the hydrolysis or decomposition of the $\mathrm{LiPF}_{6}$ salt. The chemical diffusion coefficients of $\mathrm{Li}$ ions in $\mathrm{F}-\mathrm{SnO}_{2} @ \mathrm{rGO}$ and $\mathrm{SnO}_{2} @ \mathrm{rGO}$ electrodes were calculated from EIS measurements as $\sim 1 \times 10^{-16}$ and $\sim 4 \times 10^{-17} \mathrm{~cm}^{2} \mathrm{~s}^{-1}$, respectively. More recently, $\mathrm{F}-\mathrm{SnO}_{2} @ \mathrm{rGO}$ synthesized by hydrothermal process was mixed with artificial graphite and proposed as an anode by Zhang et al. [210]. It maintained specific capacities of $440 \mathrm{mAh} \mathrm{g}^{-1}$ at $500 \mathrm{~mA} \mathrm{~g}^{-1}$ with high capacity retention of $96.28 \%$ after 500 cycles. Electrochemical performance of $\mathrm{SnO}_{2} / \mathrm{rGO}$ composite anodes for LIBs from the recent literature are summarized in Table 3.

Table 3. Electrochemical performance of $\mathrm{SnO}_{2} / \mathrm{GO}$ composites as anode materials for Li-ion batteries. Relevant cycle number is given in brackets.

\begin{tabular}{|c|c|c|c|c|}
\hline Material & Synthesis & $\begin{array}{l}\text { Specific Capacity } \\
\left(\mathrm{mAh} \mathrm{g}^{-1}\right)\end{array}$ & $\begin{array}{l}\text { Current Density } \\
\left(\mathrm{A} \mathrm{g}^{-1}\right)\end{array}$ & Ref. \\
\hline $\mathrm{SnO}_{2} / \mathrm{rGO}$ & in-situ hydrolysis & 600 & $0.05(20)$ & [198] \\
\hline $\mathrm{H}-\mathrm{SnO}_{2} / \mathrm{rGO}$ & hydrothermal reduction & 552 & $1.0(500)$ & [194] \\
\hline PS@GO/SnO 2 & hydrolysis & 781 & $0.1(100)$ & [197] \\
\hline $\mathrm{SnO}_{2} / \mathrm{rGO}$ & spray drying + thermal treatment & 708 & $0.5(150)$ & [201] \\
\hline $\mathrm{SnO}_{2-\mathrm{x}} / \mathrm{rGO}$ & precipitation & 950 & $0.1(1100)$ & [211] \\
\hline $\mathrm{F}-\mathrm{SnO}_{2} / \mathrm{rGO}$ & hydrothermal @180 C/12 h & 1037 & $0.1(150)$ & [188] \\
\hline $\mathrm{F}-\mathrm{SnO}_{2} / \mathrm{rGO}$ & hydrothermal & 440 & $0.5(500)$ & [210] \\
\hline $\mathrm{HP}-\mathrm{SnO}_{2} / \mathrm{rGO}$ & hydrolysis + calcination & 850 & $0.3 \mathrm{C}(100)$ & [199] \\
\hline $\mathrm{W}-\mathrm{SnO}_{2} / \mathrm{rGO}$ & hydrothermal reduction & 1100 & $0.1(100)$ & [187] \\
\hline $\mathrm{Zn}-\mathrm{SnO}_{2} / \mathrm{rGO}$ & sol-gel + freeze-drying & 628 & $0.1(200)$ & [212] \\
\hline $\mathrm{SnO}_{2} / \mathrm{GO}$ & ultrasonication + calcination & 492 & $2 C(100)$ & [202] \\
\hline $\mathrm{SnO}_{x} / \mathrm{rGO}$ & chemical reduction & 767 & $0.1(100)$ & [205] \\
\hline $\mathrm{Fe} @ \mathrm{SnO}_{2} / \mathrm{rGO}$ & wet chemistry & 1353 & $0.1(100)$ & [206] \\
\hline $\mathrm{Sb}-\mathrm{SnO}_{2} / \mathrm{rGO}$ & in-situ microwave-assisted & 577 & $60 \mathrm{C}$ & [211] \\
\hline $\mathrm{F}-\mathrm{SnO}_{2} \mathrm{NCs} / \mathrm{rGO}$ & hydrothermal & 1277 & $0.1(100)$ & [209] \\
\hline $\mathrm{SnO}_{2} / \mathrm{rGO}$ & precipitation + calcination & 522 & $0.03(50)$ & [200] \\
\hline
\end{tabular}

\subsection{Manganese-Based Oxide Composites}

Manganese-based oxides such as $\mathrm{MnO}, \mathrm{Mn}_{3} \mathrm{O}_{4}, \mathrm{Mn}_{2} \mathrm{O}_{3}, \mathrm{MnO}_{2}$, and their derivatives are attractive anode materials because of their theoretical specific capacity of 755, 936, 1018, and $1232 \mathrm{mAh} \mathrm{g}^{-1}$, respectively [213-216]. In addition, they exhibit high safety, low cost, and environmental benignity and manganese is an abundant element. The improved performance (i.e., discharge capacity, high rate capability, kinetics of inserted ions, and long-term cyclability) of the $\mathrm{MnO}_{2} / \mathrm{rGO}$ composite electrodes 
as anode materials have been evidenced by several electrochemical techniques, accounting for their extraordinary cycling properties compared with that in a simple $\mathrm{MnO}_{2}$ electrode. Generally, the volume expansion of $\mathrm{MnO}_{2}$ during the charge-discharge process is significantly alleviated due to the uniform dispersion and firm anchoring of $\mathrm{MnO}_{2}$ nanoparticles on the rGO surface.

\subsection{1. $\mathrm{MnO}_{2}$-Based Composite}

$\mathrm{MnO}_{2}$ has received much attention because of its low cost, ease of fabrication, environment friendliness, low operating voltage, existence of several polymorphs with tunnel-like structure (depending on the linkage of fundamental $\mathrm{MnO}_{6}$ octahedral units) [217]. The $\beta-\mathrm{MnO}_{2}$ phase crystallizes with the rutile-like tetragonal symmetry $\left(P 4_{2} / m n m(136)\right.$ space group) and possesses $1 \times 1$ tunnels $(0.23 \mathrm{~nm} \times 0.23 \mathrm{~nm})$. The $\alpha-\mathrm{MnO}_{2}$ phase is widely used in batteries and supercapacitors due to its large $2 \times 2$ tunnel structure (tetragonal, I4/m (87) space group) along c-axis with $\mathrm{MnO}_{6}$ octahedral units, which favors short diffusion path and easy ionic transport. However, the low conductivity of $\alpha-\mathrm{MnO}_{2}\left(\sim 10^{-5} \mathrm{~S} \mathrm{~cm}^{-1}\right)$ inhibits its application in high power devices. To overcome these drawbacks, workers have fabricated $\mathrm{MnO}_{2}$ nanocomposites using carbon-based materials as conducting additives. Hydrothermal method is the most popular route to prepare $\mathrm{MnO}_{2} / \mathrm{rGo}$ composite using various reaction times [218,219]. Other techniques include in-situ electrodeposition [220], spray coating [221], ionic layer adsorption and reaction (SILAR) method [222], redox reaction [223], precipitation method [224], room temperature solution method [225], and co-electrodepossition [226].

Zhang et al. [227] reported the electrochemical performance of $\beta-\mathrm{MnO}_{2} / \mathrm{rGO}$ composite anode synthesized by hydrothermal route at $160{ }^{\circ} \mathrm{C}$ for $6 \mathrm{~h}$ in solution containing $\mathrm{HCl}$. The composite product cycled in the voltage range of $0.01-3.0 \mathrm{~V}$ at $100 \mathrm{~mA} \mathrm{~g}^{-1}$ current rate delivered an initial discharge/charge capacity of $1475 / 746 \mathrm{mAh} \mathrm{g}^{-1}$ and maintained a sustainable reversible capacity of $448 \mathrm{mAh} \mathrm{g}^{-1}$ over 50 cycles. The same group of researchers used the as-prepared composite as anode material in an all-solid-state lithium-ion battery with $\mathrm{Li}_{7} \mathrm{La}_{3} \mathrm{Zr}_{2} \mathrm{O}_{12}$ as the solid electrolyte (20 $\mu \mathrm{m}$ thick) and $\mathrm{LiCoO}_{2}$ as the cathode material. When cycled at $2 \mu \mathrm{A} \mathrm{cm}{ }^{-2}$ current density, the $\left(\mathrm{MnO}_{2} / \mathrm{rGO}\right) / \mathrm{Li}_{7} \mathrm{La}_{3} \mathrm{Zr}_{2} \mathrm{O}_{12} / \mathrm{LiCoO}_{2}$ cell delivered a capacity of $1.87 \mu \mathrm{Ah} \mathrm{cm}^{-2}$ [228]. Ali et al. [229] utilized a one-step electrochemical synthesis to generate $\mathrm{MnO}_{2} / \mathrm{rGO}$ nanocomposite from $\mathrm{Mn}_{3} \mathrm{O}_{4}$ and GO starting materials. Performing a simple in-situ hydrothermal method at $160{ }^{\circ} \mathrm{C}$ for $6 \mathrm{~h}$, Liu and coworkers [230] used $\mathrm{MnO}_{2}$ nanorods (a-phase) for the fabrication of $\mathrm{MnO}_{2} / 3 \mathrm{D}-\mathrm{rGO}$ composites with a large specific surface area of $\sim 150 \mathrm{~m}^{2} \mathrm{~g}^{-1}$. Galvanostatic discharge/charge measurements showed that the first discharge occurs as a long potential plateau at ca. $0.31 \mathrm{~V}$ attributed to the reduction of $\mathrm{MnO}_{2}$ to $\mathrm{Mn}\left(\mathrm{MnO}_{2}+4 \mathrm{Li}^{+}+4 \mathrm{e}^{-} \leftrightarrow \mathrm{Mn}+2 \mathrm{Li}_{2} \mathrm{O}\right)$ and a weak potential plateau at ca. $0.03 \mathrm{~V}$ assigned to the $\mathrm{Li}$ insertion into graphene $\left(\mathrm{C}+x \mathrm{Li}^{+}+x \mathrm{e}^{-} \leftrightarrow \mathrm{Li}_{\mathrm{x}} \mathrm{C}\right)$. The initial discharge capacity of $1515 \mathrm{mAh} \mathrm{g}^{-1}$ decreased to $812 \mathrm{mAh} \mathrm{g}^{-1}$ in subsequent cycles and reached the value $\sim 595 \mathrm{mAh} \mathrm{g}^{-1}$ after 60 cycles at $0.1 \mathrm{~A} \mathrm{~g}^{-1}$ current rate and high CE of 99\%. A MnO nanoflake (birnessite type)-reduced graphene oxide $\left(\mathrm{MnO}_{2} / \mathrm{rGO}\right)$ composite was synthesized by a one-step solution method (i.e., redox reaction of $\mathrm{KMnO}_{4}$ and $\mathrm{rGO}$ in 0.5 mol L ${ }^{-1} \mathrm{H}_{2} \mathrm{SO}_{4}$ solution) [231]. The composite yielded a reversible capacity of 1430 and $520 \mathrm{mAh} \mathrm{g}^{-1}$ at current densities of 0.1 and 10 $\mathrm{A} \mathrm{g}^{-1}$, respectively, and a capacity retention of $1000 \mathrm{mAh} \mathrm{g}^{-1}$ after 200 cycles at the current density of $1 \mathrm{~A} \mathrm{~g}^{-1}$. Lee et al. [225] synthesized $\mathrm{rGO} / \mathrm{a}-\mathrm{MnO}_{2}$ nanocomposites via a simple solution method at room temperature using $1 \mathrm{wt} \%$ cetyltrimethylammonium bromide (CTAB) in the rGO suspension as surfactant and protection layer to prevent direct reaction between $\mathrm{rGO}$ and $\mathrm{MnO}_{4}{ }^{-}$ions. With a $\mathrm{MnO}_{2}$ loading of $75 \mathrm{wt} \%$, the BET surface area was $324 \mathrm{~m}^{2} \mathrm{~g}^{-1}$ and the average pore size was evaluated as 3-4 nm. The discharge and charge capacities of the as prepared nanocomposite in the first cycle were $\sim 1450$ and $\sim 850 \mathrm{mAh} \mathrm{g}^{-1}$, respectively, at $100 \mathrm{~mA} \mathrm{~g}^{-1}$ current density in the voltage range $0.01-3.0 \mathrm{~V}$. Discharge specific capacities of 222 and $115 \mathrm{mAh} \mathrm{g}^{-1}$ at a current density of 5 and $10 \mathrm{~A} \mathrm{~g}^{-1}$, respectively, maintained after 400 cycles. Chae et al. [232] suggested to prepare $\mathrm{MnO}_{2} / \mathrm{rGO}$ composites using an unrecognized chemical method by induction of intra-stacked assembly from $\mathrm{MnO}_{2} \mathrm{NRs}$ (birnessite $\mathrm{d}-\mathrm{MnO}_{2}$ ) and $\mathrm{GO}$ through polyethylenimine (PEI)-derived electrostatic modulation between both 
constituents. The hierarchical, $2 \mathrm{D} \mathrm{MnO}_{2} / \mathrm{rGO}$ hybrids (73.2:26.8 in weight) enabled highly reversible capacities of $880,770,630$, and $460 \mathrm{mAh} \mathrm{g}^{-1}$ at current densities of $0.1,1,3$, and $5 \mathrm{~A} \mathrm{~g}^{-1}$, respectively.

Highly performing $\mathrm{rGO} / \mathrm{MnO}_{2}$ mesoporous nanocomposites were fabricated in a Teflon-lined stainless-steel autoclave kept at $150{ }^{\circ} \mathrm{C}$ for $15 \mathrm{~h}$ using pre-synthesized a- $\mathrm{MnO}_{2}$ nanowires (diameter of 40-50 nm and length of 5-10 $\mu \mathrm{m}$ ) dispersed in solution with GO sheets [233]. The $\mathrm{rGO} / \mathrm{a}-\mathrm{MnO}_{2}$ composite anode featured a reversible specific capacity of $998 \mathrm{mAh} \mathrm{g}^{-1}$ at a current density of $60 \mathrm{~mA} \mathrm{~g}^{-1}$ after 30 cycles and rate capability of $590 \mathrm{mAh} \mathrm{g}^{-1}$ at $12 \mathrm{~A} \mathrm{~g}^{-1}$ current rate. The outstanding electrochemical performance is due to the increase of the BET specific surface area of the nanowires from 37.7 to $110.7 \mathrm{~m}^{2} \mathrm{~g}^{-1}$ after graphene coverage and the inhibition of the $\mathrm{MnO}_{2}$ nanowires agglomeration by graphene coating. Ma et al. [234] mitigated the capacity fading of $\mathrm{MnO}_{2}$ at high cycling rates by anchoring $\mathrm{MnO}_{2}$ nanorods (average diameter of $\sim 100 \mathrm{~nm}$ and length of $\sim 750 \mathrm{~nm}$ ) on the surface of graphene. The composite was prepared by hydrothermal route at $160^{\circ} \mathrm{C}$ for $18 \mathrm{~h}$ using a mixture of $\mathrm{MnO}_{2}$ nanorods (synthesized from aqueous solution of $\mathrm{MnSO}_{4} \cdot \mathrm{H}_{2} \mathrm{O}$ and $\mathrm{KMnO}_{4}$ (ratio 2:5 in $w t \%)$ ), GO sheets (prepared by the modified Hummers' method), and (3-Aminopropyl) triethoxysilane (APTES) as reducing agent. The $\mathrm{MnO}_{2} / \mathrm{rGO}$ composite showed superior electrochemical performance with reversible capacity of $600 \mathrm{mAh} \mathrm{g}^{-1}$ after 650 cycles at $0.5 \mathrm{~A} \mathrm{~g}^{-1}$ current density. When cycled at a high rate of $5 \mathrm{~A} \mathrm{~g}^{-1}$, a reversible specific capacity of $168 \mathrm{mAh} \mathrm{g}^{-1}$ was delivered (Figure 7). $\mathrm{Li}$ et al. [235] designed a polypyrrole nanoparticles $(\sim 10 \mathrm{~nm})$ wrapped $\mathrm{MnO}_{2} /$ reduced graphene oxide/carbon nanotubes composite $\left(\mathrm{PPy} / \mathrm{MnO}_{2} / \mathrm{rGO}-\mathrm{CNTs}\right)$. In this heterostructure, $\mathrm{CNTs}$ act as conductive medium and rGO nanosheets work as both reactive material and carrier for in situ growth of $\mathrm{MnO}_{2}$. The PPy/MnO$/$ /rGO-CNTs shell-layer anode achieved a reversible specific capacity of $1748 \mathrm{mAh} \mathrm{g}^{-1}$ at $100 \mathrm{~mA} \mathrm{~g}^{-1}$ current density after 200 cycles and still features $941 \mathrm{mAh} \mathrm{g}^{-1}$ at $1 \mathrm{~A} \mathrm{~g}^{-1}$ current rate after 1200 cycles. Flexible graphene-wrapped carbon nanotube/graphene@ $\mathrm{MnO}_{2} 3 \mathrm{D}$ multilevel porous films were fabricated via vacuum freeze-drying [236]. The outstanding nanosized pores provided vast accessible active sites and alleviated volume change. The $\mathrm{CNT} / \mathrm{rGO} @ \mathrm{MnO}_{2}$ porous film as an anode in lithium cell showed a high capacity of $1344.2 \mathrm{mAh} \mathrm{g}^{-1}$ over 630 cycles at $2 \mathrm{~A} \mathrm{~g}^{-1}$, and superior cycling stability of $608.5 \mathrm{mAh} \mathrm{g}^{-1}$ over 1000 cycles at $7.5 \mathrm{~A} \mathrm{~g}^{-1}$.
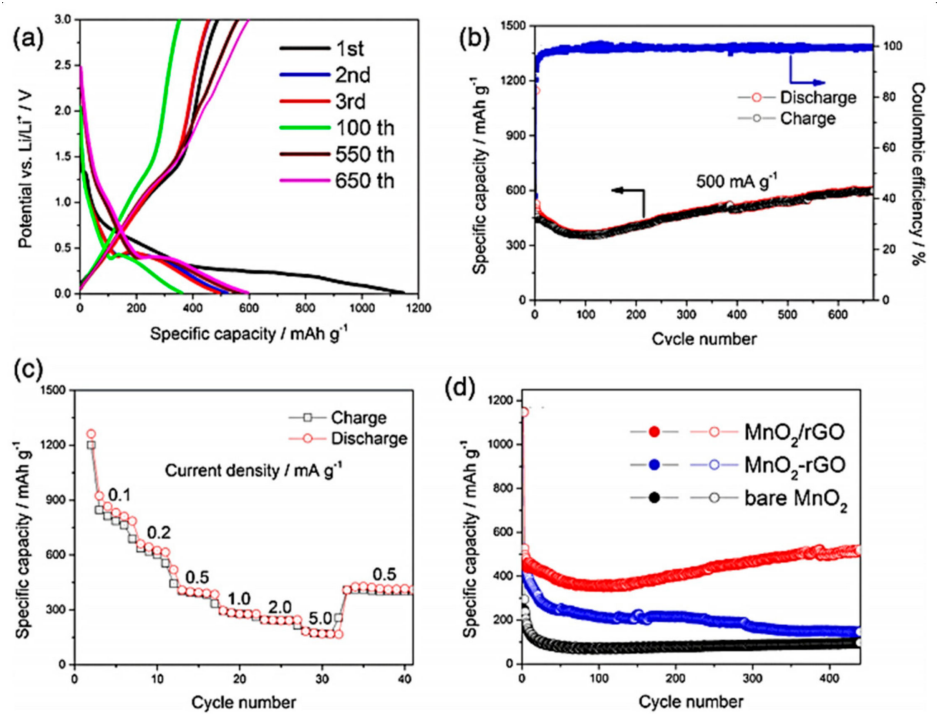

Figure 7. Electrochemical properties of $\mathrm{MnO}_{2} / \mathrm{rGO}$ composite synthesized with (3-Aminopropyl) triethoxysilane (APTES). (a) Galvanostatic discharge-charge profiles of $\mathrm{MnO}_{2} / \mathrm{rGO}$ composite at $0.5 \mathrm{~A} \mathrm{~g}^{-1}$ for different cycles, (b) cycle performance and Coulombic efficiency of $\mathrm{MnO}_{2} / \mathrm{rGO}$ composite at a current rate of $0.5 \mathrm{~A} \mathrm{~g}^{-1}$, (c) rate capabilities of $\mathrm{MnO}_{2} / \mathrm{rGO}$ composite at current density ranging from 0.1 to $5 \mathrm{~A} \mathrm{~g}^{-1}$, (d) comparison of the cycle performance of $\mathrm{MnO}_{2} / \mathrm{rGO}$ composite with $\mathrm{MnO}_{2}$-rGO synthesized without APTES and bare $\mathrm{MnO}_{2}$ at $0.5 \mathrm{~A} \mathrm{~g}^{-1}$ current density. Reproduced with permission from [234]. Copyright 2016 Elsevier. 
Kim et al. [237] employed a new strategy to construct sequentially stacked a- $\mathrm{MnO}_{2} / \mathrm{rGO}$ composites driven by surface-charge-induced mutual electrostatic interactions. The as-prepared hybrid displayed a reversible charge/discharge capacity of $1100 \mathrm{mAh} \mathrm{g}^{-1}$ without capacity fading after 100 cycles. A free-standing reduced graphene oxide/ $\mathrm{MnO}_{2}$-reduced graphene oxide-carbon nanotube nanocomposite was fabricated using vacuum filtration and thermal annealing [238]. The $\mathrm{rGO} / \mathrm{MnO}_{2} / \mathrm{CNTS}$ hybrid anode with $56 \mathrm{wt} \% \mathrm{MnO}_{2}$ cycled 100 times at $0.1 \mathrm{~A} \mathrm{~g}^{-1}$ current rate yielded a specific capacity of $1172 \mathrm{mAh} \mathrm{g}^{-1}$, as $71 \%$ of the initial capacity.

Layered manganese oxides (birnessite $\delta-\mathrm{MnO}_{2}$ phase) are also considered as promising cathode materials for lithium-ion and lithium-sulfur batteries, and supercapacitors. Ultrathin layered $\mathrm{MnO}_{2}$ nanosheets were attached on the surface of rGO sheets by one-pot precipitation method to form $2 \mathrm{D} \mathrm{MnO}_{2} / \mathrm{rGO}$ nanocomposites used as cathode materials for Li-ion batteries [224]. The initial discharge-specific capacity of $279.7 \mathrm{mAh} \mathrm{g}^{-1}$ was maintained at $242 \mathrm{mAh} \mathrm{g}^{-1}$ after 60 cycles at $0.1 \mathrm{C}$ rate. The synthesis of $\mathrm{MnO}_{2} / \mathrm{rGO}$ nanocomposites was realized using ultrasonication with $\mathrm{Mn}$ powder under mildly acidic conditions, which is a efficient reducing agent for $\mathrm{GO}$ and the $\mathrm{MnO}_{2}$ precursor [239]. Ternary composites of GO-polyaniline (PANI)- $\mathrm{MnO}_{2}$ nanorods were synthesized by a two-step process: (a) Coating solution-exfoliated GO nanosheets with polyaniline and (b) dispersion of graphene oxide sheets and $\mathrm{MnO}_{2}$ nanorods in solution by ultrasonication and self-assembly during the second aniline polymerization [240]. In such a hybrid, the PANI layer anchors $\mathrm{MnO}_{2}$ nanorods onto the surface of GO and prevents GO sheets and $\mathrm{MnO}_{2}$ nanorods from stacking/aggregating. Chan et al. prepared rGO-wrapped $\mathrm{MnO}_{2}$ composite electrode by an electrodeposition method using an electrolyte formed a solution of manganese acetate with L-ascorbic acid added to a dispersed solution of GO. A 13-min electrodeposition process leads spherical shaped- $\mathrm{MnO}_{2}$ nanoparticles $(\sim 100 \mathrm{~nm})$ and absence of $\mathrm{rGO}$ agglomeration [241]. Recently, Yang et al. [219] demonstrated that the $\mathrm{MnO}_{2} / \mathrm{rGO} / \mathrm{S}$ composite prepared by one-step hydrothermal method using $\mathrm{GO}$ and hollow $\mathrm{MnO}_{2}$ spheres (birnessite-type) as precursors can facilitates a fast-electronic transfer. The $\mathrm{MnO}_{2} / \mathrm{rGO} / \mathrm{S}$ composite exhibited a BET specific surface area and the total pore volume $15.3 \mathrm{~m}^{2} \mathrm{~g}^{-1}$ and $0.059 \mathrm{~cm}^{3} \mathrm{~g}^{-1}$, respectively. This cathode showed a first discharge specific capacity of $1202 \mathrm{mAh} \mathrm{g}^{-1}$ at current density of $0.2 \mathrm{C}\left(1 \mathrm{C}=1675 \mathrm{mAh} \mathrm{g}^{-1}\right)$ and a capacity retention of $61.4 \%$ after 100 cycles at $1 \mathrm{C}$ rate, which corresponds to only $\sim 0.38 \%$ decay per cycle.

The syntheses and supercapacitive behaviors of composite materials combining either GO or rGO with manganese-based oxide have been the subjects of intensive researches. The high capacitance values of $\mathrm{MnO}_{2} / \mathrm{rGO}$ composites are most likely attributed to the synergistic effect originating from the high surface area of $\mathrm{MnO}_{2}$ nanoparticles, the high conductivity of rGO nanosheets, and the high porosity of nanocomposites. Sawangphruk et al. [221] produced $\mathrm{MnO}_{2} / \mathrm{rGO}$ nanocomposites on graphitized carbon fiber paper by a spray coating method. The as-prepared $\mathrm{MnO}_{2} / \mathrm{rGO}$ composite displayed a specific surface area of $490 \mathrm{~m}^{2} \mathrm{~g}^{-1}$, which is slightly lower than that of pure $\mathrm{rGO}\left(510 \mathrm{~m}^{2} \mathrm{~g}^{-1}\right)$ indicating that the composite is rather stable and still dispersed. A specific capacity of $393 \mathrm{~F} \mathrm{~g}^{-1}$ at a scan rate of $10 \mathrm{mV} \mathrm{s}^{-1}$ was obtained in $0.5 \mathrm{~mol} \mathrm{~L}^{-1} \mathrm{Na}_{2} \mathrm{SO}_{4}$ electrolyte. Zhu et al. assembled an interconnected $\mathrm{rGO} / \mathrm{b}-\mathrm{MnO}_{2}$ binary hybrid electrode with ultrafine $\mathrm{MnO}_{2}$ nanostructure and precisely mass-loading control for high performance ESC [242]. The typical hybrid hydrogel also showed outstanding cycling stability with $96.3 \%$ capacitance retention after 10,000 cycles. In the work of Chen et al. [243], needle-like $\mathrm{MnO}_{2}$-GO nanocomposites were fabricated by soft-chemical route using the double-solvent system of a water-isopropyl alcohol. These composites demonstrated the specific capacitance of $197 \mathrm{~F} \mathrm{~g}^{-1}$ at $0.2 \mathrm{~A} \mathrm{~g}^{-1}$ current density. Wang et al. synthesized $\mathrm{MnO}_{2}$ nanowire-GO and $\mathrm{MnOOH}$ nanowire-GO hybrids for ESCs using a redox reaction between $\mathrm{KMnO}_{4}$ and GO, and hydrothermal reaction without any extra reductants, respectively. The maximum specific capacitances of 155 and $76 \mathrm{~F} \mathrm{~g}^{-1}$ at current density of $0.1 \mathrm{~A} \mathrm{~g}^{-1}$ were obtained, respectively, in $5 \%$ ammonia aqueous solution [223]. Lu et al. [244] demonstrated that the $\mathrm{CNTs} / \mathrm{RGO} / \mathrm{MnO}_{2}$ composite (with the $\mathrm{d}-\mathrm{MnO}_{2}$ phase) as electrode of ESC in $2 \mathrm{~mol} \mathrm{~L}^{-1} \mathrm{Na}_{2} \mathrm{SO}_{4}$ electrolyte delivered specific capacitances of 404 and $82 \mathrm{~F} \mathrm{~g}^{-1}$ at 1.0 and $10 \mathrm{~A} \mathrm{~g}^{-1}$ 
current densities. The long-term charge-discharge test indicates that the specific capacitance remained $70 \%$ after 5000 cycles under current density of $30 \mathrm{~A} \mathrm{~g}^{-1}$.

In the work of Hareech and coworkers, a ternary nanocomposite, which consists of $\mathrm{MnO}_{2}$ nanorods and reduced graphene oxide sheets supported on poly(3,4-ethylenedioxythiophene) -poly(styrenesulfonate) (PEDOT:PSS) polymer, was developed for ESC applications [245]. Electrochemical studies demonstrate a specific capacitance of $633 \mathrm{~F} \mathrm{~g}^{-1}$ at $0.5 \mathrm{~A} \mathrm{~g}^{-1}$ current density and $100 \%$ stability over 5000 cycles at $1 \mathrm{~A} \mathrm{~g}^{-1}$ rate in acetonitrile containing lithium perchlorate as electrolyte. Seredych et al. reported the preparation of $\mathrm{MnO}_{2} / \mathrm{GO}$ composites containing only $10 \mathrm{wt} \% \mathrm{GO}$ of different oxidation levels and low crystallization birnessite-type $\mathrm{MnO}_{2}$; specific capacitance of $125 \mathrm{~F} \mathrm{~g}^{-1}$ at current density of $0.1 \mathrm{Ag}^{-1}$ was obtained [246]. Nanostructured a- $\mathrm{MnO}_{2} / \mathrm{rGO}$ composites with different weight feed ratios of graphene to $\mathrm{MnO}_{2}$ (1:1, 1:2 and 2:1) were synthesized by coprecipitation under alkaline conditions. The a-MnO $\mathrm{M}_{2} / \mathrm{rGO}(1: 1)$ hybrid, which exhibited a BET specific surface area of $174 \mathrm{~m}^{2} \mathrm{~g}^{-1}$ and $\sim 26 \mathrm{~nm}$ average pore diameter had a specific capacitance of $367 \mathrm{~F} \mathrm{~g}^{-1}$ at current density of $1 \mathrm{~A} \mathrm{~g}^{-1}$ (i.e., 4.6-fold higher than of $\mathrm{MnO}_{2}$ ) [247]. Miniach et al. [248] studied a $\mathrm{MnO}_{2} / \mathrm{rGO}$ via a hydrothermal technique with good specific capacitance of $157 \mathrm{~F} \mathrm{~g}^{-1}$ and energy density of $21 \mathrm{Wh} \mathrm{kg}^{-1}$. Chen et al. [249] offered a $\mathrm{rGO} / \mathrm{MnO}_{2} /$ carbon black ternary hybrid with desirable specific capacitance of $209 \mathrm{~F} \mathrm{~g}^{-1}$ and higher energy density of $24.3 \mathrm{Wh} \mathrm{kg}^{-1}$ in $0.5 \mathrm{~mol} \mathrm{~L}^{-1} \mathrm{Na}_{2} \mathrm{SO}_{4}$ aqueous electrolyte at room temperature. In this study, the $\mathrm{rGO} / \mathrm{MnO}_{2}$ hybrid films were prepared using a vacuum filtration route by the mixture of the $\mathrm{KMnO}_{4}$ solution with the rGO dispersion through cellulose esters filter. A flexible asymmetric ESC including $\mathrm{CuO} @ \mathrm{MnO}_{2} / \mathrm{rGO}$ and $\mathrm{MoS}_{2} / \mathrm{rGO}$ as positive and negative hybrid electrodes, respectively, showed only $8.1 \%$ capacitance loss after 10,000 cycles and an outstanding energy density of $165.6 \mathrm{Wh} \mathrm{kg}^{-1}$ and a power density of $1992 \mathrm{~W} \mathrm{~kg}^{-1}$ [250]. PANI/ $\mathrm{MnO}_{2} /$ graphene composite was prepared by pulse electrodeposition method (current density of $2 \mathrm{~mA} \mathrm{~cm}^{-2}$, pulse frequency of $1 \mathrm{kHz}$ ). The $\gamma$-phase $\mathrm{MnO}_{2}$ nanoparticles are uniformly distributed on the PANI nanorods, which increases the specific surface area [251]. A $\mathrm{MnO}_{2} / \mathrm{rGO} / \mathrm{CNTs}$ framework was designed to inhibit the shuttle effect of lithium-sulfur batteries. It was fabricated by hydrothermal method at $180^{\circ} \mathrm{C}$ for $12 \mathrm{~h}$ using $\mathrm{KMnO}_{4}, \mathrm{GO}, \mathrm{CNTs}$, and $\mathrm{H}_{3} \mathrm{PO}_{4} \cdot \mathrm{H}_{2} \mathrm{O}$. The hybrid was composed by $\mathrm{MnO}_{2}$ short nanorods ( $\alpha$-phase, diameter of $50 \mathrm{~nm}$, and length of $\sim 200 \mathrm{~nm}$ ) compounded with carbon nanotubes (diameter of 20-50 nm) and tulle-like rGO and exhibited a mesoporous structure with average pore size of $\sim 12 \mathrm{~nm}$ [252]. The $\mathrm{MnO}_{2} / \mathrm{rGO} / \mathrm{CNTs} / \mathrm{S}$ cathode delivered an initial specific capacity of $1010 \mathrm{mAh} \mathrm{g}^{-1}$ at $0.5 \mathrm{C}$ rate and achieved $780 \mathrm{mAh} \mathrm{g}^{-1}$ after 200 cycles (i.e., capacity decay rate of $0.11 \%$ per cycle).

\subsection{2. $\mathrm{Mn}_{3} \mathrm{O}_{4}$-Based Composite}

$\mathrm{Mn}_{3} \mathrm{O}_{4}$ (hausmannite, tetragonal structure) has gained much attention as anode material due to its high reversible capacity, low oxidation potential, abundance, and environmental friendliness [253]. $\mathrm{Mn}_{3} \mathrm{O}_{4}$ can react with $8 \mathrm{Li}$ ions per formula unit (i.e., conversion reaction to form lithium oxide and metal nanoparticles: $\mathrm{Mn}_{3} \mathrm{O}_{4}+8 \mathrm{Li}^{+}+8 \mathrm{e}^{-} \leftrightarrow 3 \mathrm{Mn}+4 \mathrm{Li}_{2} \mathrm{O}$ ) leading to a theoretical specific capacity of about $936 \mathrm{mAh} \mathrm{g}^{-1}$ [254]. For the first time, in 2010, Wang and coworkers [255] reported the deposition of $\mathrm{Mn}_{3} \mathrm{O}_{4}$ nanoparticles onto rGO sheets as anode materials for LIBs. $\mathrm{Mn}_{3} \mathrm{O}_{4} / \mathrm{rGO}$ hybrids were fabricated by two-step solution phase reaction, i.e., hydrolysis in DMF followed by a hydrothermal process in water. The authors stated that $\mathrm{Mn}_{3} \mathrm{O}_{4}$ nanoparticles were possibly grown on the oxygen functional group on GO. With the assistance of rGO, this composite exhibited a capacity of 900 and $390 \mathrm{mAh} \mathrm{g}^{-1}$ at 40 and $1600 \mathrm{~mA} \mathrm{~g}^{-1}$, respectively.

$\mathrm{Mn}_{3} \mathrm{O}_{4} / \mathrm{rGO}$ composites have been synthesized using combined techniques such as co-precipitation and subsequent flame procedure [256-258], hydrothermal method [259,260], in situ reduction by hydrazine vapour [261], sonication with subsequent heat treatment [262], gel formation and electrochemical reduction process [263], one-step reduction in aqueous phase [264,265], successive ionic layer adsorption and reaction (SILAR) method [222], flame plasma [256], and sonochemistry-assisted method [266,267]. Gund et al. investigated the capacitive performance of hybrid $\mathrm{Mn}_{3} \mathrm{O}_{4} / \mathrm{GO}$ composite prepared by the SILAR method, which implicates the sequential immersion ( $20 \mathrm{~s}$ duration) of the 
charged substrate in separately placed cationic $\left(\mathrm{MnSO}_{4}\right)$ and anionic $(\mathrm{NaOH})$ solution, with the deposition of the monolayer of different species on the substrate in one cycle. The composite electrode with $\mathrm{Mn}_{3} \mathrm{O}_{4}$ nanograins of $20 \mathrm{~nm}$ and BET specific surface area of $94 \mathrm{~m}^{2} \mathrm{~g}^{-1}$ showed the specific capacitance of 344 and $180 \mathrm{~F} \mathrm{~g}^{-1}$ at scan rate of 5 and $20 \mathrm{mV} \mathrm{s}^{-1}$, respectively, in $1 \mathrm{~mol} \mathrm{~L}^{-1} \mathrm{Na}_{2} \mathrm{SO}_{4}$ electrolyte [222]. Nanosized $\mathrm{Mn}_{3} \mathrm{O}_{4}$ particles grown on $\mathrm{rGO}$ were prepared by precipitation method via refluxing in solution containing $\mathrm{MnCl}_{2} \cdot 4 \mathrm{H}_{2} \mathrm{O}$ and $\mathrm{KMnO}_{4}$ added to $\mathrm{GO}$ dispersion with various $\mathrm{MnCl}_{2} \cdot 4 \mathrm{H}_{2} \mathrm{O} / \mathrm{GO}$ ratios [268]. The $\mathrm{Mn}_{3} \mathrm{O}_{4} / \mathrm{rGO}$ hybrid with $72 \% \mathrm{Mn}_{3} \mathrm{O}_{4}(\sim 30 \mathrm{~nm}$ in size $)$ delivered an initial discharge capacity of $\sim 1226 \mathrm{mAh} \mathrm{g}^{-1}$ at $120 \mathrm{~mA} \mathrm{~g}^{-1}$ current rate, higher than the theoretical value of $989 \mathrm{mAh} \mathrm{g}^{-1}$ because of high surface area and charge accumulation at active sites commonly observed in nanomaterials [269]. However, the best rate capability and cyclability were obtained with the composition of $54 \% \mathrm{Mn}_{3} \mathrm{O}_{4}$ (i.e., a capacity of $531 \mathrm{mAh} \mathrm{g}^{-1}$ was maintained after 40 cycles at $0.1 \mathrm{C}$ rate) due to the minimum particle agglomeration. Seong et al. [262] compared the performance of an acid-treated $\mathrm{rGO} / \mathrm{Mn}_{3} \mathrm{O}_{4}$ nanorods ( $\mathrm{ArGO} / \mathrm{Mn}_{3} \mathrm{O}_{4} \mathrm{NRs}$ ) composite with that of its parent $\mathrm{rGO} / \mathrm{Mn}_{3} \mathrm{O}_{4}$ NRs synthesized by a simple mixing of $\mathrm{GO}$ and $\mathrm{MnOOH}$ (3:1 weight ratio) using sonication followed by heat treatment at $400{ }^{\circ} \mathrm{C}$ for $5 \mathrm{~h}$ in $\mathrm{N}_{2}$ atmosphere. The ArGO/Mn ${ }_{3} \mathrm{O}_{4} \mathrm{NRs}$ and $\mathrm{rGO} / \mathrm{Mn}_{3} \mathrm{O}_{4} \mathrm{NRs}$ had a mesoporous morphology with BET specific surface areas of 73.8 and $48.1 \mathrm{~m}^{2} \mathrm{~g}^{-1}$, respectively. Tests carried out at $200 \mathrm{mAh} \mathrm{g}^{-1}$ current density in the potential range 3.0-0.01 V showed that $\mathrm{rGO} / \mathrm{Mn}_{3} \mathrm{O}_{4}$ and $\mathrm{ArGO} / \mathrm{Mn}_{3} \mathrm{O}_{4}$ electrodes deliver an initial discharge capacity of 1100 and $1130 \mathrm{mAh} \mathrm{g}^{-1}$ and then a reversible capacity of 695 and $778 \mathrm{mAh} \mathrm{g}^{-1}$, respectively. The first cycling capacity loss was due to the formation of the SEI and the reduction of $\mathrm{Mn}_{3} \mathrm{O}_{4}\left(\mathrm{Mn}^{3+}\right)$ to $\mathrm{MnO}\left(\mathrm{Mn}^{2+}\right)$, which occurs as a broad cathodic peak in the range $0.5-1.9 \mathrm{~V}$. In the second cycle, the strong cathodic peak at ca. $0.35 \mathrm{~V}$ is assigned to the reduction of $\mathrm{MnO}\left(\mathrm{Mn}^{2+}\right)$ to $\mathrm{MnO}$, while the anodic peak at $1.3 \mathrm{~V}$ is the fingerprint of the oxidation reaction of $\mathrm{Mn}$ to $\mathrm{MnO}$.

More recently, Rosaiah et al. [270] reported the $\mathrm{Mn}_{3} \mathrm{O}_{4} @ \mathrm{rGO}$ composite for ESCs and LIBs. Nithya et al. demonstrated the application of the $\mathrm{Mn}_{3} \mathrm{O}_{4} @ \mathrm{rGO}$ composite for K-ion Batteries [271]. The rGO/ $\mathrm{Mn}_{3} \mathrm{O}_{4}$ hybrid anode reported by Nam et al. [272] delivers a reversible capacity of $1294 \mathrm{mAh} \mathrm{g}^{-1}$ at $100 \mathrm{~mA} \mathrm{~g}^{-1}$ after 100 cycles. A low-cost and green ultrasound-assisted method was developed by Luo [273]. For the rapid synthesis of $\mathrm{Mn}_{3} \mathrm{O}_{4}$ nanosheets supported on $\mathrm{rGO}, \mathrm{Mn}(\mathrm{OAc})_{2}$ and GO obtained according to the Hummers' method were dispersed in aqueous solution in the presence of tert-butylamine. Such anode materials yielded a high specific capacity of $\sim 1400 \mathrm{mAh} \mathrm{g}^{-1}$ after 40 cycles at a current density of $100 \mathrm{~mA} \mathrm{~g}^{-1}$ (based on the mass of $\mathrm{Mn}_{3} \mathrm{O}_{4}$ ). A coprecipitation method was used to fabricate a 3D GO/Mn ${ }_{3} \mathrm{O}_{4}$ hybrid, which exhibited a large specific capacity of $949 \mathrm{mAh} \mathrm{g}^{-1}, \mathrm{CE}$ of $\sim 98 \%$. After 100 cycles at $100 \mathrm{~mA} \mathrm{~g}^{-1}$ current rate, the specific capacity remained at $792 \mathrm{mAh} \mathrm{g}^{-1}$ with a CE of 98.1\% [257]. Li et al. [274] took advantage of C-O-Mn chemical bonds to prepare graphene nanosheets dispersed in porous $\mathrm{Mn}_{3} \mathrm{O}_{4}$ making a 3D $\mathrm{Mn}_{3} \mathrm{O}_{4} / \mathrm{rGO}$ hybrid, which displayed excellent performance as anode of LIBs and electrode of ESCs by simply tuning the graphene content $(<7 \mathrm{wt} \%)$. As LIB anode, with $6.9 \mathrm{wt} \% \mathrm{rGO}$, BET specific surface area of $153 \mathrm{~m}^{2} \mathrm{~g}^{-1}$, and $\sim 5 \mathrm{~nm}$ pore size, the composite featured a reversible capacity of $\sim 1500 \mathrm{mAh} \mathrm{g}^{-1}$ at $50 \mathrm{~mA} \mathrm{~g}^{-1}$, and $561 \mathrm{mAh} \mathrm{g}^{-1}$ at $1 \mathrm{~A} \mathrm{~g}^{-1}$. Zhang et al. [275] took advantage of the effective synergy between $\mathrm{MnCO}_{3}$ and $\mathrm{Mn}_{3} \mathrm{O}_{4}$ to fabricate a multicomponent hybrid with the configuration $\mathrm{MnCO}_{3} / \mathrm{Mn}_{3} \mathrm{O}_{4} / \mathrm{rGO}$. In a typical experiment, a $\mathrm{GO} / \mathrm{Mn}$ suspension (yellow color) was first obtained by mixing GO prepared by the modified Hummers'method with $\mathrm{KMnO}_{4}$ at $0{ }^{\circ} \mathrm{C}$ for $3 \mathrm{~h}$. Second, the as-prepared GO/Mn suspension was treated ultrasonically for $1 \mathrm{~h}$ to exfoliate the GO layers and added to $\mathrm{Na}_{2} \mathrm{CO}_{3}$ solution $\left(1 \mathrm{~mol} \mathrm{~L}{ }^{-1}\right)$ under stirring to adjust the $\mathrm{pH}$ value of the whole suspension to 11 . Then, reduction of GO to rGO was obtained in an alkaline solution maintained at $95^{\circ} \mathrm{C}$ for $2 \mathrm{~h}$. Parents $\mathrm{MnCO}_{3} / \mathrm{rGO}$ and $\mathrm{Mn}_{3} \mathrm{O}_{4} / \mathrm{rGO}$ composite were prepared using similar procedure changing the $\mathrm{pH}$ and the alkaline solution, respectively (Figure $8 \mathrm{~A}$ ). The $\mathrm{MnCO}_{3} / \mathrm{Mn}_{3} \mathrm{O}_{4} / \mathrm{rGO}$ ternary composite displayed a cycling stability of $988 \mathrm{mAh} \mathrm{g}^{-1}$ after 200 cycles at $0.1 \mathrm{~A} \mathrm{~g}^{-1}$ current rate and $532 \mathrm{mAh} \mathrm{g}^{-1}$ after 800 cycles at $1 \mathrm{~A} \mathrm{~g}^{-1}$ (Figure 8B). 
(A)

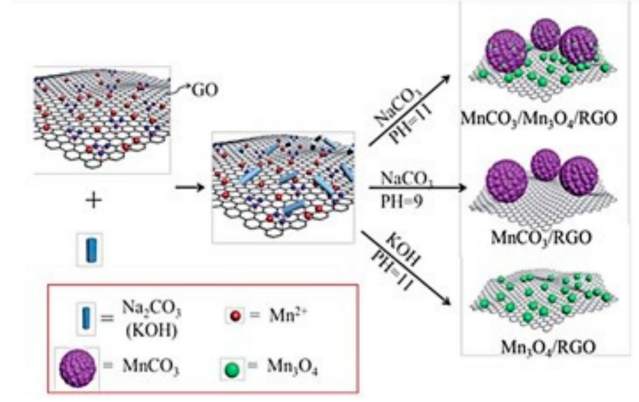

B)
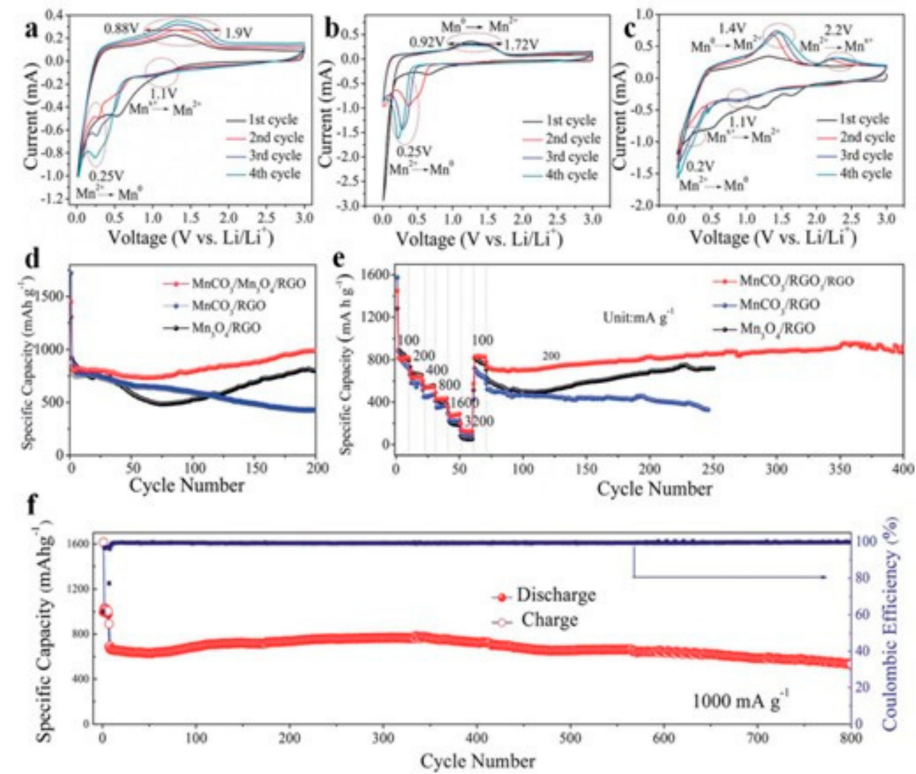

Figure 8. (A) Schematic illustration of the synthesis processes of multicomponent composites. (B) Cyclic voltammetry curves of (a) $\mathrm{MnCO}_{3} / \mathrm{Mn}_{3} \mathrm{O}_{4} / \mathrm{rGO}$ composites, (b) $\mathrm{MnCO}_{3} / \mathrm{rGO}$ composites, and (c) $\mathrm{Mn}_{3} \mathrm{O}_{4} / \mathrm{rGO}$ composites. (d) Cycling performances at $100 \mathrm{~mA} \mathrm{~g}^{-1}$. (e) Rate capabilities of the $\mathrm{MnCO}_{3} / \mathrm{Mn}_{3} \mathrm{O}_{4} / \mathrm{rGO}$ composites, $\mathrm{MnCO}_{3} / \mathrm{rGO}$ composites, and $\mathrm{Mn}_{3} \mathrm{O}_{4} / \mathrm{rGO}$ composites. (f) Long-term cycling performance with coulombic efficiency of $\mathrm{MnCO}_{3} / \mathrm{Mn}_{3} \mathrm{O}_{4} / \mathrm{rGO}$ composites at $1 \mathrm{~A} \mathrm{~g}^{-1}$. Reproduced with permission from Ref. [275]. Copyright 2017 The Royal Society of Chemistry.

The $\mathrm{Mn}_{3} \mathrm{O}_{4} / \mathrm{rGO}$ designed by Shah et al. was prepared by the hydrothermal treatment at $180{ }^{\circ} \mathrm{C}$ for $18 \mathrm{~h}$ of an aqueous alkaline solution of $\mathrm{MnCl}_{2}, \mathrm{GO}$, and $\mathrm{NaOH}$ [276]. The presence of $\mathrm{Mn}_{3} \mathrm{O}_{4}$ nanoparticles on the surface of graphene nanosheets makes the structure with porous morphology. The rGO-Mn ${ }_{3} \mathrm{O}_{4}$ electrode tested over 5000 cycles displayed a high specific capacitance of $457 \mathrm{~F} \mathrm{~g}^{-1}$ at $1 \mathrm{~A} \mathrm{~g}^{-1}$ current rate. By means of a novel surfactant-free, single-step hydrothermal method, Varghese et al. [277] synthesized the $\mathrm{Mn}_{3} \mathrm{O}_{4}$ nanostructures and their rGO composites. The morphology of $\mathrm{Mn}_{3} \mathrm{O}_{4} / \mathrm{rGO}$ composite revealed that $\mathrm{Mn}_{3} \mathrm{O}_{4}$ nano-octahedrons ( 100-150 nm in size) were wrapped in the graphene matrix. The $\mathrm{Mn}_{3} \mathrm{O}_{4} / \mathrm{rGO} \| \mathrm{Li}$ half-cell showed a reversible specific capacity of $474 \mathrm{mAh} \mathrm{g}^{-1}$ at $100 \mathrm{~mA} \mathrm{~g}^{-1}$ upon 200 cycles. Further, a high capacitive contribution of $\sim 73 \%$ (evaluated at $1.0 \mathrm{mV} \mathrm{s}^{-1}$ sweep rate) contributed to fast $\mathrm{Li}^{+}$ion kinetics of this anode.

\subsubsection{MnO-Based Composites}

Manganese monoxide $(\mathrm{MnO})$ has drawn considerable attention as anode material for LIBs due to its high theoretical capacity of $755.6 \mathrm{mAh} \mathrm{g}^{-1}$ and relatively low voltage hysteresis. However, poor cyclic performance and inferior rate capability caused by the severe particle agglomeration and large volume expansion are challenging issues. Exfoliated graphene oxide (EGO)/MnO composite $(35 / 65 \mathrm{wt} \%)$ powders synthesized by simple solid state graphenothermal reduction process (specific 
surface area of $\sim 82 \mathrm{~m}^{2} \mathrm{~g}^{-1}$ and an average pore size of $\sim 12 \mathrm{~nm}$ ) were formed by cubic MnO crystallites that anchored onto EG surfaces. Tested as an anode in lithium-ion batteries, the EGO/MnO composite exhibited high reversible capacity of $936 \mathrm{mAh} \mathrm{g}^{-1}$ at a current rate of $75 \mathrm{~mA} \mathrm{~g}^{-1}$ with a capacity retention of $\sim 84 \%$ and $\mathrm{CE}$ of $99 \%$ over 100 cycles [278]. The reversible conversion reactions of $\mathrm{MnO}$ and electrochemical absorption/desorption by EGO were evidenced by cyclic voltammetry studies showing easy lithiation kinetics. An ever-increasing surface redox capacitive lithium storage device was fabricated with a sandwich nanostructure. $\mathrm{MnO}$ was electrodeposited on $\mathrm{rGO}$, forming interconnected nanorods (15-30 $\mathrm{nm}$ in diameter) with random orientation covered by depositing the top GO layer. The as-prepared RGO- $\mathrm{Mn}_{\mathrm{x}} \mathrm{O}_{\mathrm{y}}-\mathrm{GO}$ film was then heat treated at $600{ }^{\circ} \mathrm{C}$ for $6 \mathrm{~h}$ in $\mathrm{H}_{2} / \mathrm{Ar}$ (5:95) atmosphere to achieve the RGO-MnO-RGO product. The as-designed rGO-MnO-rGO sandwich nanostructures displayed a surface pseudocapacitance dynamically in equilibrium with the diffusion-controlled process leading ultrahigh-rate capability of $\sim 332 \mathrm{mAh} \mathrm{g}^{-1}$ at $40 \mathrm{~A} \mathrm{~g}^{-1}$ and $\sim 379 \mathrm{mAh} \mathrm{g}^{-1}$ after 4000 cycles at $15 \mathrm{~A} \mathrm{~g}^{-1}$ was achieved due to the dynamical equilibrium between surface pseudocapacitance and diffusion-controlled ion storage [279]. Cheng et al. [280] developed a MnO-based sandwiched composite within 3D graphene-based N-doped carbon (NC) networks. The $\mathrm{NC} / \mathrm{MnO} / \mathrm{rGO}$ nanohybrid was prepared by precipitation assisted by polydopamine followed by heat treatment at $700{ }^{\circ} \mathrm{C}$ for $2 \mathrm{~h}$ in $\mathrm{H}_{2}$ /Ar atmosphere. HRTEM analysis showed that $\mathrm{MnO}$ nanoparticles (40 nm in size) were completely wrapped by a uniform amorphous carbon layer with a thickness about $2 \mathrm{~nm}$, and then anchored on the rGO matrix. It demonstrated high reversible capacity of $1360 \mathrm{mAh} \mathrm{g}^{-1}$ at $0.2 \mathrm{~A} \mathrm{~g}^{-1}$ over 150 cycles, excellent rate capability, and good cyclability $\left(648 \mathrm{mAh} \mathrm{g}^{-1}\right.$ at $2 \mathrm{~A} \mathrm{~g}^{-1}$ without fading over 600 cycles). A composite anode, which consisted of rGO-anchored $\mathrm{MnO}$ within an nitrogen-codoped carbon coating (rGO/MnO@NC) was prepared under solvothermal conditions (at $180{ }^{\circ} \mathrm{C}$ for $15 \mathrm{~h}$ ) of suspension of $\mathrm{rGH}$ sheets with manganese acetate followed by a two-step heat treatment with dopamine to produce the rGO/MnO@NC final hybrid (at $400{ }^{\circ} \mathrm{C}$ for $2 \mathrm{~h}$ with a heating rate of $1{ }^{\circ} \mathrm{C} \mathrm{min}^{-1}$ under a pure argon flow and then at $800{ }^{\circ} \mathrm{C}$ for $2 \mathrm{~h}$ at a heating rate of $3{ }^{\circ} \mathrm{C} \mathrm{min}{ }^{-1}$ ). This composite electrode presented high specific capacity of $699 \mathrm{mAh} \mathrm{g}^{-1}$ at $0.1 \mathrm{~A} \mathrm{~g}^{-1}$, and excellent cycling performance of $607 \mathrm{mAh} \mathrm{g}^{-1}$ at $1 \mathrm{~A} \mathrm{~g}^{-1}$ over 550 cycles [281]. Table 4 summarizes the electrochemical performances of Mn-based oxide/rGO composite anodes of rechargeable lithium batteries.

Table 4. Comparison of the electrochemical behaviors of Mn-based oxide/rGO composite anodes of rechargeable lithium batteries. The relevant graphene content in $w \mathrm{t} \%$ (a) and cycle number (b) are displayed in brackets.

\begin{tabular}{|c|c|c|c|c|}
\hline Material $^{\text {(a) }}$ & Synthesis & $\begin{array}{l}\text { Specific Capacity } \\
\left(\mathrm{mAh} \mathrm{g}^{-1}\right)\end{array}$ & $\begin{array}{c}\text { Current Density } \\
\left(\mathrm{A} \mathrm{g}^{-1}\right)\end{array}$ & Ref. \\
\hline $\mathrm{b}-\mathrm{MnO}_{2} / \mathrm{rGO}$ & hydrothermal @160C/6 h & 448 & $0.1(50)$ & [227] \\
\hline $\mathrm{d}-\mathrm{MnO}_{2} \mathrm{NF} / \mathrm{rGO}$ & redox reaction with $\mathrm{KMnO}_{4}$ & 1000 & $1(200)$ & [231] \\
\hline $\mathrm{a}-\mathrm{MnO}_{2} / \mathrm{rGO}$ & solution method with $\mathrm{CTAB}$ & 222 & $5(200)$ & [225] \\
\hline $\mathrm{a}-\mathrm{MnO}_{2} / \mathrm{rGO}$ & hydrothermal @150 C $/ 15$ h & 590 & $12(30)$ & [233] \\
\hline $\mathrm{CNT} / \mathrm{rGO} @ \mathrm{MnO}_{2}$ & vacuum freeze-drying & 608 & $7.5(1000)$ & [236] \\
\hline $\mathrm{PPy} / \mathrm{MnO}_{2} / \mathrm{rGO}-\mathrm{CNTs}$ & vacuum filtration & 941 & $1(1200)$ & {$[235]$} \\
\hline $\mathrm{rGO} / \mathrm{MnO}_{2} / \mathrm{CNTS}$ & vacuum filtration + thermal annealing & 1172 & $0.1(100)$ & [238] \\
\hline $\mathrm{Mn}_{3} \mathrm{O}_{4} / \mathrm{rGO}(10)$ & two-step solution-phase reaction & 900 & $0.04(5)$ & [255] \\
\hline $\mathrm{MnO} / \mathrm{GO}(9.17)$ & impregnation + thermal reduction & 500 & $0.2 \mathrm{C}(32)$ & [282] \\
\hline $\mathrm{MnO} / \mathrm{rGO}(72.5)$ & two-step liquid phase deposition & 665 & $0.1(50)$ & [286] \\
\hline $\mathrm{MnO} \mathrm{NWs} / \mathrm{GO}$ & dialysis & 930 & $0.1(470)$ & [287] \\
\hline MnO NRs/GO (7.58) & in-situ reduction & 705 & $0.05(100)$ & [288] \\
\hline $\mathrm{MnO} / \mathrm{rGO}(6)$ & pyrolysis & 950 & $0.1(5)$ & [289] \\
\hline $\mathrm{MnO}$ NSs/rGO & hydrolysis + calcination & 648 & $0.75(50)$ & [290] \\
\hline
\end{tabular}




\subsection{Molybdenum-Based Oxide Composites}

Since 1987, $\mathrm{MoO}_{2}$ has been recognized as anode material for lithium-ion batteries [291]. Bulk $\mathrm{MoO}_{2}$ possesses excellent physical properties with a metallic conductivity of $\sim 10^{-4} \mathrm{~S} \mathrm{~cm}^{-1}$ at room temperature and a theoretical specific capacity as high as $838 \mathrm{mAh} \mathrm{g}^{-1}$. It adopts the distorted variant of the rutile-like structure (monoclinic, $P 21 / c$ space group) in which the metal atoms occur in pairs along the $\mathrm{c}$ axis of the rutile pseudo-cell [292]. In the 0.01-3.0 V potential range, the lithiation of the $\mathrm{MoO}_{2}$ electrode investigated by cyclic voltammetry occurs with two steps (first discharge): (1) The Li insertion $\left(\mathrm{Li}_{0.98} \mathrm{MoO}_{2}\right)$ evidenced by the 1.52 and $1.24 \mathrm{~V}$ reduction peaks attributed to the monoclinic orthorhombic phase transition and (2) below $0.7 \mathrm{~V}$ reduction peaks assigned to the conversion of $\mathrm{MoO}_{2}$ into elemental Mo with 3Li uptake [293,294]. However, inherent disadvantages of bulk $\mathrm{MoO}_{2}$ anode are the low reversible capacity due to sluggish lithiation/delithiation kinetics [295], the substantial volume change during lithiation process, which result in rapid capacity fading and poor capacity retention [296].

Graphene oxide was used as a reducing agent of $\mathrm{MoO}_{3}$ (molar ratio of 4:1) and as a source for exfoliated graphene oxide (EGO) to fabricate $\mathrm{EGO} / \mathrm{MoO}_{2}$ composites with $46 \mathrm{wt} \%$ graphene [297]. The small particle size of $\sim 33 \mathrm{~nm}$ indicates that agglomeration of $\mathrm{MoO}_{2}$ has been controlled with the increased amount of EGO. The initial capacity of $713 \mathrm{mAh} \mathrm{g}^{-1}$ increased slightly to $878 \mathrm{mAh} \mathrm{g}^{-1}$ after 100 cycles at $100 \mathrm{~mA} \mathrm{~g}^{-1}$ current rate in the voltage window $0.005-3.0 \mathrm{~V}$. Kinetics investigated by cyclic voltammetry revealed high values of the diffusion coefficients of $\mathrm{Li}$ ions in the range $6 \times 10^{-10}-1 \times 10^{-11} \mathrm{~cm}^{2} \mathrm{~s}^{-1}$ during $\mathrm{Li}_{x} \mathrm{MoO}_{2}$ lithiation $(0<x<4)$. Hu et al. [298] prepared $\mathrm{MoO}_{2} / \mathrm{GO}$ composites via hydrothermal route at $200^{\circ} \mathrm{C}$ for $24 \mathrm{~h}$ using Mo powder and exfoliated GO produced by sonication. $\mathrm{MoO}_{2}$ nanoparticles (5-15 nm in size) were homogeneously dispersed on GO. When tested as an anode material for lithium, the $\mathrm{MoO}_{2} / \mathrm{GO}$ composite displayed an initial specific capacity of 780 and $500 \mathrm{mAh} \mathrm{g}^{-1}$ at 0.1 and $0.5 \mathrm{~A} \mathrm{~g}^{-1}$, respectively. The beneficial contribution of exfoliated $\mathrm{GO}$ was evidenced by EIS measurements, as the charge transfer resistance of $44 \mathrm{~W}$ for $\mathrm{MoO}_{2} / \mathrm{GO}$ was much lower than $300 \mathrm{~W}$ for pure $\mathrm{MoO}_{2}$ nanoparticles, due to more conductive pathway for Li-ion transportation. $\mathrm{MnO}_{2} /$ graphene composite was also synthesized by an effective polymer-assisted chemical reduction method, which provides nanosized $\mathrm{MnO}_{2}$ particles homogeneously distributed on graphene nanosheets [299].

Huang and coworkers [300] fabricated a composite of $\mathrm{MoO}_{2}$ nanoparticles ( 100 nm) anchored on GO for sodium-ion battery anodes. This $\mathrm{MoO}_{2} / \mathrm{GO}$ hybrid (15 wt $\left.\% \mathrm{GO}\right)$ yielded a discharge capacity of $483 \mathrm{mAh} \mathrm{g}^{-1}\left(\sim 2318 \mathrm{mAh} \mathrm{cm}^{-3}\right)$ at the current density of $100 \mathrm{~mA} \mathrm{~g}^{-1}$ and a capacity fading of $0.019 \%$ per cycle over the first 1000 cycles. Tang et al. reported the electrochemical properties of rGO-wrapped $\mathrm{MoO}_{2}$ porous nanobelts $\left(\mathrm{rGO} / \mathrm{MoO}_{2} \mathrm{NBs}\right)$ synthesized using a reduction process of the $\mathrm{GO}-\mathrm{MoO}_{3}$ hybrids with $\mathrm{Ar} / \mathrm{ethanol}$ vapor at $400{ }^{\circ} \mathrm{C}$ for $12 \mathrm{~h}$ [301]. The full-scale multi-electron conversion reaction in $\mathrm{rGO} / \mathrm{MoO}_{2} \mathrm{NBs}$ (with $8 \mathrm{wt} \% \mathrm{rGO}$ ) led to a high reversible capacity of $974 \mathrm{mAh} \mathrm{g}^{-1}$ at the current density of $60 \mathrm{~mA} \mathrm{~g}^{-1}$ after the 6th cycle and, after initial activation, a specific capacity of $420 \mathrm{mAh} \mathrm{g}^{-1}$ was retained at the end of 1900 cycles at $5 \mathrm{~A} \mathrm{~g}^{-1}$ rate. Zhu et al. [302] demonstrated that $\mathrm{rGO} / \mathrm{MoO}_{2}$ nanobelt composite (with $19.4 \mathrm{wt} \% \mathrm{rGO}$ ) synthesized by a simple thermal reduction of $\mathrm{MoO}_{3}$ and GO at $550{ }^{\circ} \mathrm{C}$ for $2 \mathrm{~h}$ in a $10 \% \mathrm{H}_{2} / \mathrm{Ar}$ atmosphere had a BET specific surface area and pore volume of $17.68 \mathrm{~m}^{2} \mathrm{~g}^{-1}$ and $0.09 \mathrm{~cm}^{3} \mathrm{~g}^{-1}$, respectively. This self-assembled hybrid showed attractive electrochemical performance as LIB anodes with specific discharge capacity reaching $584 \mathrm{mAh} \mathrm{g}^{-1}$ after 100 cycles at $1 \mathrm{~A} \mathrm{~g}^{-1}$.

In 2017, Ju and coworkers [303] designed a $\mathrm{TiO}_{2} / \mathrm{rGO} / \mathrm{MoO}_{2} @ \mathrm{Mo}$ composite electrode for ESC. This architectural nanostructure with 3D walnut-shape synthesized by one-step hydrothermal method was composed of amorphous $\mathrm{TiO}_{2}$ decorating the $\mathrm{rGO} / \mathrm{MoO}_{2}$ surface grown on Mo foam. It exhibited a specific capacitance of $1636 \mathrm{~F} \mathrm{~g}^{-1}$ at $1.25 \mathrm{~A} \mathrm{~g}^{-1}$ with only $3.5 \%$ capacitance loss after 5000 cycles. Tightly anchored $\mathrm{MoO}_{2}$ nanoparticles (10-20 nm in size) deposited on the basal plane of rGO were fabricated using a green supercritical methanol $(\mathrm{scMeOH})$ route. When tested as an anode in lithium cells, the composite with $37 \mathrm{wt} \% \mathrm{MoO}_{2}$ loading (BET surface area of $14.3 \mathrm{~m}^{2} \mathrm{~g}^{-1}, 15 \%$ porosity) 
delivered a reversible capacity of $793 \mathrm{mAh} \mathrm{g}^{-1}$ at $50 \mathrm{~mA} \mathrm{~g}^{-1}$ current rate [304]. Graphene oxide flexibly supported $\mathrm{MoO}_{2}$ porous hybrids were constructed by decomposition of $\left(\mathrm{NH}_{4}\right)_{2} \mathrm{MoO}_{4} / \mathrm{GO}$ preforms with the percentage of GO at 4.3, 15.2, and $20.8 \mathrm{wt} \%$. The lithium storage performance was investigated at the current density of $0.1 \mathrm{~A} \mathrm{~g}^{-1}$ using various $\mathrm{MoO}_{2} / \mathrm{GO}$ architectures showing specific capacities of 901,1127 , and $967 \mathrm{mAh} \mathrm{g}^{-1}$ after 100 cycles for micrometer $\mathrm{MoO}_{2} / \mathrm{GO}, \mathrm{MoO}_{2} / \mathrm{GO}$ nanohoneycomb, and layered $\mathrm{MoO}_{2} / \mathrm{GO}$, respectively. The $\mathrm{MoO}_{2} / \mathrm{GO}$ nanohoneycomb delivered the capacity of $461 \mathrm{mAh} \mathrm{g}^{-1}$ at $5 \mathrm{~A} \mathrm{~g}^{-1}$ current rate with $\mathrm{CE}$ of $99.3 \%$ [305]. Wang et al. [306] synthesized 2D layered mesoporous- $\mathrm{MoO}_{2} / \mathrm{rGO}$ composites $\left(\mathrm{m}-\mathrm{MoO}_{2} / \mathrm{rGO}\right)$ through a novel strategy using silica KIT-6/rGO as a template and ammonium molybdate as a precursor via a nanocasting method with subsequent heat treatment heated up to $600{ }^{\circ} \mathrm{C}$ for $6 \mathrm{~h}$ at a rate of $2{ }^{\circ} \mathrm{C} \mathrm{min}{ }^{-1}$ in a mixed gas flow of $\mathrm{H}_{2} / \mathrm{Ar}$ (10:90). Analyses of the morphology validated the ordered mesoporous structure with a BET specific surface area of $86 \mathrm{~m}^{2} \mathrm{~g}^{-1}$, a pore size of 3-4 nm in a large domain, and a pore volume of $0.19 \mathrm{~cm}^{3} \mathrm{~g}^{-1}$. The $\mathrm{m}-\mathrm{MoO}_{2} / \mathrm{rGO}$ (1:1) electrode delivered an initial discharge capacity of $1160 \mathrm{mAh} \mathrm{g}^{-1}$ at current density of $0.1 \mathrm{~A} \mathrm{~g}^{-1}$ with a capacity loss of $31.9 \%$ during the first cycle and a reversible capacity is $801 \mathrm{mAh} \mathrm{g}^{-1}$ after 50 cycles.

In 2018, Chen et al. [307] investigated a hierarchical $\mathrm{MoO}_{2} @ \mathrm{rGO}\left(\sim 10 \mathrm{~nm} \mathrm{MoO}_{2}\right.$ particle size and $21.1 \mathrm{wt} \% \mathrm{rGO}$ ) composite prepared by hydrothermal route at $200{ }^{\circ} \mathrm{C}$ for 2 days, which exhibited outstanding electrochemical performance with a reversible capacity of $708 \mathrm{mAh} \mathrm{g} \mathrm{g}^{-1}$ at a current density of $0.5 \mathrm{~A} \mathrm{~g}^{-1}$ after 50 cycles. A capacity of $473 \mathrm{mAh} \mathrm{g}^{-1}$ was maintained when cycled at $2 \mathrm{~A} \mathrm{~g}^{-1}$ current rate. $\mathrm{Li}$ et al. [308] utilized Mo particles as both the reductant for GO and as the Mo source to prepare $\mathrm{MoO}_{2} / \mathrm{rGO}$ hybrid anodes. The $\mathrm{MoO}_{2} / \mathrm{rGO}$ composite with Mo:GO of 3:1 was used as an efficient cathode catalyst for the oxygen reduction reaction (ORR). Recently, Liu et al. [309] reported the direct growth of $\mathrm{MoO}_{2} / \mathrm{rGO}$ hollow sphere composites through hydrothermal technique. This advanced anode materials tested in potassium-ion batteries delivered a reversible specific capacity of $219 \mathrm{mAh} \mathrm{g}^{-1}$ after 200 cycles at $50 \mathrm{~mA} \mathrm{~g}^{-1}$ current rate. When cycled at $0.5 \mathrm{~A} \mathrm{~g}^{-1}$, a high charge specific capacity of $104 \mathrm{mAh} \mathrm{g}^{-1}$ was achieved after 500 cycles. Li et al. [310] prepared the $\mathrm{MoO}_{2} / \mathrm{Mo}-\mathrm{GO}$ hybrids using a freeze-drying technique, which exhibited a high ICE of $97 \%$. A capacity of $550 \mathrm{mAh} \mathrm{g}^{-1} \mathrm{ws}$ delivered by the $\mathrm{MoO}_{2} / \mathrm{Mo}-\mathrm{GO}$ anode materials after 150 cycles at $0.1 \mathrm{~A} \mathrm{~g}^{-1}$ rate. Devina et al. [311] used the same technique to prepare $\mathrm{MoO}_{2} / \mathrm{rGO}$ composite attached with $\mathrm{Mo}_{2} \mathrm{C}$ during carbothermal hydrogen reduction. The $\mathrm{MoO}_{2} / \mathrm{Mo}_{2} \mathrm{C} / \mathrm{rGO}$ product displayed an increased initial coulombic efficiency (77\%), long-term cyclability (500 $\mathrm{mAh} \mathrm{g}^{-1}$ at $50 \mathrm{~mA} \mathrm{~g}^{-1}$ after 150 cycles), and high-rate performance (200 mAh g ${ }^{-1}$ at $1 \mathrm{~A} \mathrm{~g}^{-1}$ ) compared with those of the $\mathrm{MoO}_{2} / \mathrm{rGO}$ composite $\left(53 \% ; 280 \mathrm{mAh} \mathrm{g}^{-1}\right.$ at $50 \mathrm{~mA} \mathrm{~g}^{-1}$ after 150 cycles; $120 \mathrm{mAh} \mathrm{g}^{-1}$ at $1 \mathrm{~A} \mathrm{~g}^{-1}$ ).

Recently, the fabrication of submicrometer-sized $\mathrm{MoO}_{2} @ \mathrm{MoS}_{2} / \mathrm{rGO}$ composite with a hierarchical core-shell structure was suggested by Zheng et al. [312]. The three-step synthesis includes: (i) The preparation of the $\mathrm{MoO}_{2} @ \mathrm{MoS}_{2}$ precursor using a solid-state reaction (i.e., $\mathrm{MoO}_{3}$ and sulfur heated at $600{ }^{\circ} \mathrm{C}$ for $1 \mathrm{~h}$ in a gas stream of $\mathrm{Ar} / \mathrm{H}_{2}(90: 10)$ ), (ii) a hydrothermal process at $180^{\circ} \mathrm{C}$ for $4 \mathrm{~h}$ using a GO suspension, and (iii) a final heat treatment at $400{ }^{\circ} \mathrm{C}$ for $2 \mathrm{~h}$ in $\mathrm{Ar} / \mathrm{H}_{2}$ flowing gas. The electrochemical tests of the $\mathrm{MoO}_{2} @ \mathrm{MoS}_{2} / \mathrm{rGO}$ anode showed an initial reversible capacity of $833 \mathrm{mAh} \mathrm{g}^{-1}$ with ICE of $80.6 \%$ and improved cycling stability $\left(733 \mathrm{mAh} \mathrm{g}^{-1}\right.$ after 80 cycles at $0.2 \mathrm{~mA} \mathrm{~g}^{-1}$ ). The good rate capability with a capacity of $645 \mathrm{mAh} \mathrm{g}^{-1}$ at $4 \mathrm{~A} \mathrm{~g}^{-1}$ was also evidenced. An assembled $\mathrm{MoO}_{2} @ \mathrm{MoS}_{2} / \mathrm{rGO} \| \mathrm{LiCoO}_{2}$ full cell maintained a reversible capacity of $694 \mathrm{mAh} \mathrm{g}^{-1}$ (based on the mass of $\mathrm{MoO}_{2} @ \mathrm{MoS}_{2} / \mathrm{rGO}$ ) at $0.2 \mathrm{~mA} \mathrm{~g}^{-1}$ after 40 cycles. Electrochemical performance of $\mathrm{MoO}_{2} / \mathrm{rGO}$ composite anodes for LIBs from the recent literature are summarized in Table 5. 
Table 5. Electrochemical performance of $\mathrm{MoO}_{2} / \mathrm{GO}$ composites as anode materials for Li-ion batteries. The relevant cycle number is displayed in brackets.

\begin{tabular}{|c|c|c|c|c|}
\hline Material & Synthesis & $\begin{array}{l}\text { Reversible Capacity } \\
\left(\mathrm{mAh} \mathrm{g}^{-1}\right)\end{array}$ & $\begin{array}{l}\text { Current Rate } \\
\left(\mathrm{A} \mathrm{g}^{-1}\right)\end{array}$ & Ref. \\
\hline $\mathrm{MoO}_{2} / \mathrm{Gr}$ & layer-by-layer assembly & 676 & $48(100)$ & [313] \\
\hline $\mathrm{MoO}_{2} / \mathrm{Gr}$ & sonication in water (11.2) & 597 & $1000(70)$ & [26] \\
\hline $\mathrm{MoO}_{2} / \mathrm{rGO}$ & solvothermal in ethanol (10.0) & 714 & $100(30)$ & [314] \\
\hline $\mathrm{MoO}_{2} / \mathrm{rGO}$ & hydrothermal @200 들 h & 503 & $100(30)$ & [298] \\
\hline $\mathrm{MoO}_{2} / \mathrm{rGO}$ & 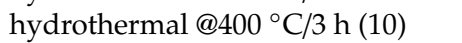 & 1009 & $100(60)$ & [315] \\
\hline $\mathrm{MoO}_{2} / \mathrm{rGO}$ & solid state reaction $(22.0)$ & 640 & $200(50)$ & [316] \\
\hline $\mathrm{MoO}_{2} / \mathrm{GO}$ & thermal reduction @550 ${ }^{\circ} \mathrm{C} / 2 \mathrm{~h}$ & 752 & $100(100)$ & [317] \\
\hline $\mathrm{MoO}_{2} / \mathrm{Gr}$ & hydrothermal @180 ${ }^{\circ} \mathrm{C} / 26$ h (33) & 769 & $540(83)$ & [318] \\
\hline $\mathrm{MoO}_{2} / \mathrm{N}-\mathrm{rGO}$ & hydrothermal @180 ${ }^{\circ} \mathrm{C} / 24$ h & 400 & $1000(5)$ & [319] \\
\hline $\mathrm{MoO}_{2} /$ exfol-rGO & solid-state graphenothermal (46) & 878 & $100(100)$ & [297] \\
\hline $\mathrm{MoO}_{2} \mathrm{NSs} / \mathrm{rGO}$ & in situ reduction of $\mathrm{MoO}_{3}$ & 1003 & $100(100)$ & [320] \\
\hline $\mathrm{MoO}_{2} / \mathrm{GO}$ & solvothermal @160 든 h (10) & 500 & $800(30)$ & [299] \\
\hline $\mathrm{MoO}_{2} / \mathrm{rGO}$ & solid-state reaction @500 ${ }^{\circ} \mathrm{C}(15)$ & 276 & $100(1000)$ & [300] \\
\hline $\mathrm{MoO}_{2} / \mathrm{rGO}$ & hydrothermal @200 ${ }^{\circ} \mathrm{C} / 2$ days (21) & 708 & $500(50)$ & [307] \\
\hline $\mathrm{MoO}_{2} / \mathrm{rGO}$ & thermal reduction @550 ${ }^{\circ} \mathrm{C}(19)$ & 584 & $1000(100)$ & [308] \\
\hline $\mathrm{MoO}_{2} / \mathrm{rGO} / \mathrm{NBs}$ & surfactant-free self-assembly & 420 & $5000(1900)$ & [302] \\
\hline $\mathrm{MoO}_{2} \mathrm{NBs} / \mathrm{rGO}$ & supercritical methanol route & 793 & $50(50)$ & [304] \\
\hline $\mathrm{MoO}_{2} / \mathrm{Mo}-\mathrm{GO}$ & freeze-drying (5) & 550 & $100(150)$ & [310] \\
\hline $\mathrm{MoO}_{2} / \mathrm{rGO}$ & solid state reaction @500 ${ }^{\circ} \mathrm{C}(15)$ & 1127 & $100(150)$ & [305] \\
\hline $\mathrm{MoO}_{2} \mathrm{NBs} / \mathrm{rGO}$ & freeze-drying (8) & 420 & $5000(1900)$ & [301] \\
\hline $\mathrm{m}-\mathrm{MoO}_{2} / \mathrm{rGO}$ & nanocasting (50) & 801 & $100(100)$ & [306] \\
\hline $\mathrm{MoO}_{2} @ \mathrm{MoS}_{2} / \mathrm{rGO}$ & hydrothermal @ $180^{\circ} \mathrm{C} / 4 \mathrm{~h}$ & 733 & $200(80)$ & [312] \\
\hline
\end{tabular}

$\mathrm{Xu}$ et al. [314] used a solvothermal treatment of a GO suspension with $\left(\mathrm{NH}_{4}\right)_{6} \mathrm{Mo}_{7} \mathrm{O}_{24}$ and $\mathrm{HNO}_{3}$ in ethanol at $160{ }^{\circ} \mathrm{C}$ for $16 \mathrm{~h}$. The $\mathrm{MoO}_{2} / \mathrm{GO}$ with $10 \mathrm{wt} \% \mathrm{GO}$ tested in lithium half-cell delivered an initial capacity of $800 \mathrm{mAh} \mathrm{g}^{-1}$ at current density of $0.8 \mathrm{~A} \mathrm{~g}^{-1}$ corresponding to Li uptake of 3.43 moles. The capacity retention was $63 \%$ after 30 cycles.

\subsection{Titanium-Based Oxide Composites}

\subsection{1. $\mathrm{TiO}_{2}$-Based Composites}

$\mathrm{TiO}_{2}$ has been widely investigated as anode material of LIBs due to its strong redox ability, relative non-toxicity, good stability, low cost, and abundance [321]. The insertion of $\mathrm{Li}^{+}$ions in the $\mathrm{TiO}_{2}$ framework occurs at about $1.5 \mathrm{~V}$ with the electrochemical process $\mathrm{TiO}_{2}+x \mathrm{Li}^{+}+x \mathrm{e}^{-} \leftrightarrow$ $\mathrm{Li}_{\mathrm{x}} \mathrm{TiO}_{2}(0 \leq x \leq 1)$ providing a theoretical capacity of $170 \mathrm{mAh} \mathrm{g}^{-1}$ (for $1 \mathrm{Li}^{+}$uptake) almost equal to $\mathrm{Li}_{4} \mathrm{Ti}_{5} \mathrm{O}_{12}$. However, pure $\mathrm{TiO}_{2}$ suffers from poor electronic conductivity $\left(\sim 10^{-12}-10^{-7} \mathrm{~S} \mathrm{~cm}^{-1}\right)$ and low diffusion rate $\left(10^{-15}-10^{-11} \mathrm{~cm}^{2} \mathrm{~s}^{-1}\right)$ [322,323], which affects the cycling performance and rate capability. To overcome these drawbacks, researchers have tried to combine $\mathrm{TiO}_{2}$ with high conductive carbonaceous substances such as graphene [324], GO [325], and rGO [326-329]. In this context, Wang et al. reported that the sandwich structure formed by carbon-coated mesoporous $\mathrm{TiO}_{2}$ nanocrystals and rGO sheets with a high surface area of $\sim 209 \mathrm{~m}^{2} \mathrm{~g}^{-1}$, and a large pore volume of $\sim 0.68 \mathrm{~cm}^{3} \mathrm{~g}^{-1}$ gives a capacity retention of $110 \mathrm{mAh} \mathrm{g}^{-1}$ after 100 cycles at $0.2 \mathrm{~A} \mathrm{~g}^{-1}$ current rate [330].

Several effective strategies proved that the $\mathrm{TiO}_{2} / \mathrm{GO}$ and $\mathrm{TiO}_{2} / \mathrm{rGO}$ composite materials exhibit enhanced electrochemical properties in comparison with pure $\mathrm{TiO}_{2}$. In most cases, the carbonaceous support results in several advantages: It provides fast transmission channels for electronic, maintains the structural stability of the hybrid, and increases the conductivity in the presence of reduced graphene oxide. The presence of carbon also provokes a reduction of the $\mathrm{TiO}_{2}$ particles size during synthesis, which can shorten the transport paths for both $\mathrm{Li}^{+}$ions and electrons and can lead to more electroactive sites due to the enlarged electrode-electrolyte contact area. In addition, the Ti-C bonds in the hybrid are crucial for fast interfacial charge transfer [331]. For instance, Etacheri et al. identified the formation of $\mathrm{Ti}^{3+}-\mathrm{C}$ bonds between $\mathrm{TiO}_{2}(\mathrm{~B})$ and $\mathrm{rGO}$ in chemically bonded mesoporous $\mathrm{TiO}_{2}(\mathrm{~B})$ nanosheets 
to rGO sheets prepared by a photocatalytic reduction method, using EPR and XPS measurements. These $\mathrm{TiO}_{2}(\mathrm{~B}) / \mathrm{rGO}$ nanohybrids demonstrated superior rate capability with $80 \%$ of the initial capacity retained after 1000 cycles at high rate of 40C [332].

Hydrothermal method is the most popular technique to prepare $\mathrm{TiO}_{2} / \mathrm{rGO}$ nanocomposites [333]. $\mathrm{TiO}_{2} / \mathrm{rGO}$ nanocomposites with small particle size were prepared via a mild hydrothermal route at $160{ }^{\circ} \mathrm{C}$ for $12 \mathrm{~h}$ with titanium tetrabutoxide $(3 \mathrm{~mL})$ and $\mathrm{GO}$ as the precursors in a mixture of ethanol $(2.5 \mathrm{~mL})$ and hydrochloric acid $(3.5 \mathrm{~mL})$; after heat treatment at $350{ }^{\circ} \mathrm{C}$ the final product with blue-black color was obtained [334]. This $\mathrm{TiO}_{2} / \mathrm{rGO}$ nanocomposite delivered a first discharge capacity of $275 \mathrm{mAh} \mathrm{g}^{-1}$ corresponding to a nominal degree of lithiation of $x=1.64$ in $\mathrm{Li}_{\mathrm{x}} \mathrm{TiO}_{2}$ and it retained a capacity of $112 \mathrm{mAh} \mathrm{g}^{-1}$ after 100 cycles at a high charge rate of $1 \mathrm{~A} \mathrm{~g}^{-1}$. Zhen et al. [327] fabricated rGO nanosheet supported anatase $\mathrm{TiO}_{2}$ fiber bundles by hydrothermal method at $180{ }^{\circ} \mathrm{C}$ for $20 \mathrm{~h}$ using the mixture of the $\mathrm{TiCl}_{3}$ and $\mathrm{NaF}$ in $\mathrm{NaOH}$ solution added to $\mathrm{GO}$ into $\mathrm{HCl}$ solution. This $\mathrm{TiO}_{2} / \mathrm{rGO}$ composite showed a mesostructure with a broad pore size distribution from 5 to $50 \mathrm{~nm}$, average $21 \mathrm{~nm}$ pore diameter and higher specific surface area of $83.8 \mathrm{~m}^{2} \mathrm{~g}^{-1}$. The galvanostatic charge-discharge patterns carried out under $200 \mathrm{~mA} \mathrm{~g}^{-1}$ current rate in the voltage range from 3 to $0.01 \mathrm{~V} \mathrm{vs}$. $\mathrm{Li}^{+} / \mathrm{Li}$ showed a capacity retention of $235 \mathrm{mAh} \mathrm{g}^{-1}$ after 1000 cycles. He et al. [328] used a mild seed-assisted hydrothermal method at $110{ }^{\circ} \mathrm{C}$ for $12 \mathrm{~h}$ with $\mathrm{Ti}(\mathrm{OBu})_{4}$ titanium source to synthesize a sandwich-like nanocomposite consisting of rutile $\mathrm{TiO}_{2}$ nanorods ( $<25 \mathrm{~nm}$ in size) onto rGO. The composite with specific surface area of $43 \mathrm{~m}^{2} \mathrm{~g}^{-1}$ demonstrated reversible capacities of $145 \mathrm{mAh} \mathrm{g}^{-1}(1 \mathrm{C})$ and $94 \mathrm{mAh} \mathrm{g}^{-1}(5 \mathrm{C})$ retained up to 100 cycles $\left(1 \mathrm{C}=168 \mathrm{mAh} \mathrm{g}^{-1}\right)$, better than that of cells composed of nanosized $\mathrm{TiO}_{2}$, i.e., $80 \mathrm{mAh} \mathrm{g}^{-1}$ at $2 \mathrm{C}$ rate ( $8 \mathrm{~nm}$ grain size, $5 \mathrm{mg} \mathrm{cm}^{-2}$ loading) [335]. $\mathrm{TiO}_{2}$ nanorods $(\sim 5 \mathrm{~nm}$ in size, anatase phase) anchored on rGO composite were fabricated by hydrothermal method $\left(180{ }^{\circ} \mathrm{C}\right.$ for $12 \mathrm{~h}$ ) after annealing treatment using $\mathrm{GO}$ solution, titanium trichloride $\left(\mathrm{TiCl}_{3}\right)$, and sodium hydroxide $(\mathrm{NaOH})$ aqueous solution. The resultant $\mathrm{R}-\mathrm{TiO}_{2} / \mathrm{rGO}$ composites (BET surface area of $\sim 149 \mathrm{~m}^{2} \mathrm{~g}^{-1}$, average pore diameter of $\sim 18 \mathrm{~nm}$ ) were explored as anode material for LIBs displaying reversible capacities of 276 and $151 \mathrm{mAh} \mathrm{g}^{-1}$ at $1 \mathrm{C}$ and $10 \mathrm{C}\left(1 \mathrm{C}=168 \mathrm{~mA} \mathrm{~g}^{-1}\right)$, respectively, with an excellent cycle ability ( $\sim 90 \mathrm{mAh} \mathrm{g}^{-1}$ at $10 \mathrm{C}$ after 1000 cycles in the potential range 0.01-3 V) [336]. $\mathrm{Li}$ and coworkers [337] reported in situ growth of anatase $\mathrm{TiO}_{2}$ nanoparticles on nitrogen-doped reduced graphene oxide $(\mathrm{N}-\mathrm{rGO})$ via hydrothermal route at $200{ }^{\circ} \mathrm{C}$ for $20 \mathrm{~h}$. The properties of the $\mathrm{TiO}_{2} / \mathrm{N}-\mathrm{rGO}$ composite were compared with those of pure $\mathrm{TiO}_{2}$ and $\mathrm{TiO}_{2} / \mathrm{rGO}$ prepared in similar conditions. However, it was noted that the presence of $\mathrm{rGO}$ results in a decrease of the particle size from $30 \mathrm{~nm}$ in $\mathrm{TiO}_{2}$ to $10-15 \mathrm{~nm}$ in $\mathrm{TiO}_{2} / \mathrm{rGO}$. The average reversible capacities of bare $\mathrm{TiO}_{2}, \mathrm{TiO}_{2} / \mathrm{rGO}$, and $\mathrm{TiO}_{2} / \mathrm{N}$-rGO were 194,210 , and $226 \mathrm{mAh} \mathrm{g}^{-1}$, respectively, at a current rate of $0.2 \mathrm{C}$. The authors discussed the effects of nitrogen doping on the electrochemical performance, in terms of defects in pyridinic graphene sheets suitable sites for lithium-ion storage. The nitrogen doping improved the conductivity by opening the bandgap and the disordered carbon structure increases the Li:C ratio. Geng et al. [338] synthesized $\mathrm{TiO}_{2} / \mathrm{rGO}$ anode materials using hydrothermal method at $150{ }^{\circ} \mathrm{C}$ for $14 \mathrm{~h}$. In a typical process, titanium oxysulfate dissolved in ethyl alcohol was mixed with multilayers GO sonically dispersed in water and hydrazine hydrate as reducing agent. The discharge specific capacity of $\mathrm{TiO}_{2} / \mathrm{rGO}$ composite was $236 \mathrm{mAh} \mathrm{g}^{-1}$ after 100 charge-discharge cycles at $0.1 \mathrm{~A} \mathrm{~g}^{-1}$ rate and the coulombic efficiency was $98.5 \%$.

In 2017, Mondal et al. [339] developed a large-scale synthesis for $\mathrm{TiO}_{2}-\mathrm{rGO}$ nanocomposite hollow spheres by an aerosol-assisted spray-drying technique (using an aqueous titanium ammonium peroxo-carbonate complex (TAPCC) solution) with subsequent calcination. The porous $\mathrm{TiO}_{2}-\mathrm{rGO}$ nanohybrid was composed of $\mathrm{TiO}_{2}$ particles $(10-20 \mathrm{~nm})$ dispersed on the surface of $\mathrm{rGO}(10 \%)$ with a BET specific surface area of $86 \mathrm{~m}^{2} \mathrm{~g}^{-1}$. Specific discharge capacities of 265 and $274 \mathrm{mAh} \mathrm{g}^{-1}$ at $18.8 \mathrm{~mA} \mathrm{~g}^{-1}$ current rate were delivered by the synthesized $\mathrm{TiO}_{2}-\mathrm{rGO}$ hollow spheres with rGO content of 10 and $20 \mathrm{wt} \%$, respectively, against $236 \mathrm{mAh} \mathrm{g}^{-1}$ for the pristine sample with a 2D flake-like morphology. Li et al. [329] prepared $\mathrm{TiO}_{2} / \mathrm{rGO}$ hybrids using an ethanol-type hydrothermal method at $180{ }^{\circ} \mathrm{C}$ for $12 \mathrm{~h}$ followed by a freeze-drying process. Samples consisted of $\mathrm{TiO}_{2}$ spherical particles 
(10 nm diameter, anatase phase) combined with the $\mathrm{rGO}$ matrix. The $\mathrm{TiO}_{2} / \mathrm{rGO}$ assembly exhibited high

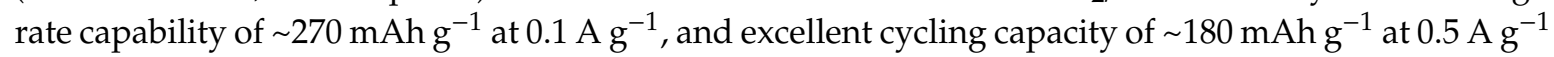
after 2000 cycles. The improvement of these electrodes was explained in terms of fast pseudocapacitive charge storage process. Enhancement of the transport of $\mathrm{Li}^{+}$ions in $\mathrm{TiO}_{2} / \mathrm{rGO}$ composite electrode was evaluated by EIS measurements showing a diffusion coefficient of $1.14 \times 10^{-11} \mathrm{~cm}^{2} \mathrm{~s}^{-1}$, against $7.4 \times 10^{-13} \mathrm{~cm}^{2} \mathrm{~s}^{-1}$ for pure $\mathrm{TiO}_{2}$ electrode. $\mathrm{A} \mathrm{TiO}_{2}(\mathrm{~B})-\mathrm{CNTs}-$ graphene ternary was synthesized by a three-step growth procedure, i.e., dispersion of Go and CNTs in ethanol, precipitation with titanium isopropoxide and ammonium hydroxide followed by a hydrothermal process at $200{ }^{\circ} \mathrm{C}$ for $48 \mathrm{~h}$ and a calcination at $350{ }^{\circ} \mathrm{C}$ for $5 \mathrm{~h}$ [340]. The $\mathrm{TiO}_{2}$ (B)-CNTs-GO sample with a $11.2 \%$ weight content carbon, including graphene and CNTs, had a BET surface area of $65.5 \mathrm{~m}^{2} \mathrm{~g}^{-1}$. It exhibited electrochemical activity within the voltage range of $0.01-3 \mathrm{~V}$ with a specific capacity of $388 \mathrm{mAh} \mathrm{g}^{-1}$ in the 2nd cycle at $0.1 \mathrm{C}$ rate and a rate capability of $76 \mathrm{mAh} \mathrm{g}^{-1}$ at $10 \mathrm{C}$. A capacity of $190 \mathrm{mAh} \mathrm{g}^{-1}$ was maintained after 200 cycles at $1 \mathrm{C}$ rate.

Recently, the hollow $\mathrm{TiO}_{2} @ \mathrm{rGO}$ hybrid spheres as anode materials for LIBs by Zhao et al. exhibited excellent electrochemical performance, i.e., high-rate and long-life [333]. The composite with a BET surface area of $58.7 \mathrm{~m}^{2} \mathrm{~g}^{-1}$ was in-situ constructed by using $\mathrm{TiO}_{2}$ spheres in $\mathrm{GO}$ suspension as a precursor and a simple in-situ hydrothermal route with subsequent annealing at $600{ }^{\circ} \mathrm{C}$ for $3 \mathrm{~h}$ under an Ar atmosphere. It exhibited a specific capacity of $254 \mathrm{mAh} \mathrm{g}^{-1}$ at $1 \mathrm{C}$ rate after 600 cycles

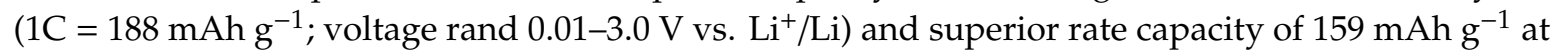
10C after 3000 cycles. Fang et al. [341] prepared a two-dimensional $\mathrm{TiO}_{2} / \mathrm{rGO}$ composite (particle size of $15-25 \mathrm{~nm}$ ) by a facile hydrothermal method at $160{ }^{\circ} \mathrm{C}$ for $16 \mathrm{~h}$ using $\mathrm{Ti}_{2} \mathrm{C}$ and $\mathrm{GO}$ as precursors. HRTEM images showed a large amount of sandwich layer-space and $\mathrm{TiO}_{2}-\mathrm{rGO}$ interfaces, which are very advantageous for electron transfer and ion transport. The average specific capacities of $302,200,170,148$, and $128 \mathrm{mAh} \mathrm{g}^{-1}$ were obtained at the current density of $0.5,2.0,10,20$, and 50C $\left(1 \mathrm{C}=168 \mathrm{~mA} \mathrm{~g}^{-1}\right)$, respectively. Even at the large current density of $100 \mathrm{C}$, the $\mathrm{TiO}_{2} / \mathrm{rGO}$ anode yielded a capacity of $111 \mathrm{mAh} \mathrm{g}^{-1}$. At the current density of $1.68 \mathrm{~A} \mathrm{~g}^{-1}$, a capacity of $130 \mathrm{mAh} \mathrm{g}^{-1} \mathrm{was}$ achieved, and an outstanding cycling retention of $86 \%$ remained after 1000 cycles. Quantification of the capacitive and diffusion contributions made from cyclic voltammetry data demonstrated that, at high currents, the capacity control was the main reaction power, i.e., accounted for $69.6 \%$ of the total charge (see Figure 9). $\mathrm{TiO}_{2} / \mathrm{rGO}$ was also used as the anode material for a $\mathrm{K}$-ion cell showing remarkable capacity retention of $83 \%$ after 1000 cycles at $1 \mathrm{~A} \mathrm{~g}^{-1}$ current rate. Farook et al. used a microwave hydrothermal process to obtain a $\mathrm{TiO}_{2}-\mathrm{rGO}$ nanocomposite consisted of $\mathrm{TiO}_{2}$ particles with a size of $\sim 100 \mathrm{~nm}$, uniformly distributed on the rGO sheets. As an anode for LIBs, it delivered a capacity of a capacity of $250 \mathrm{mAh} \mathrm{g}^{-1} \pm 5 \%$ at $0.2 \mathrm{C}$ for more than 200 cycles. A capacity of $100 \mathrm{mAh} \mathrm{g}^{-1}$ with $>99 \%$ coulombic efficiency was recorded up to 20C [342]. Subasi et al. could increase the capacity of $\mathrm{TiO}_{2}-\mathrm{rGO}$ owing to a surface modification of the nanocomposite by the use of $\mathrm{H}_{2} \mathrm{O}_{2}$ [343] . This composite, with $\mathrm{TiO}_{2} 20$ nm-thick synthesized through a sol-gel method, delivered $291 \mathrm{~mA} \mathrm{~h} \mathrm{~g}^{-1}$ at a current of $100 \mathrm{~mA} \mathrm{~g}^{-1}$. 
(a)

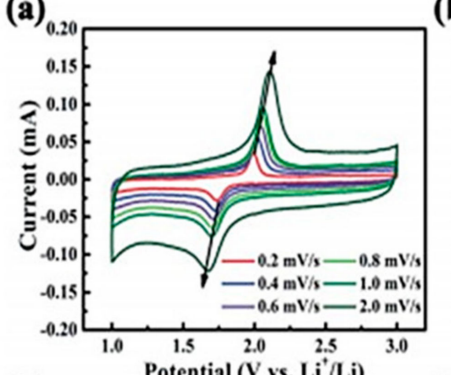

(d)

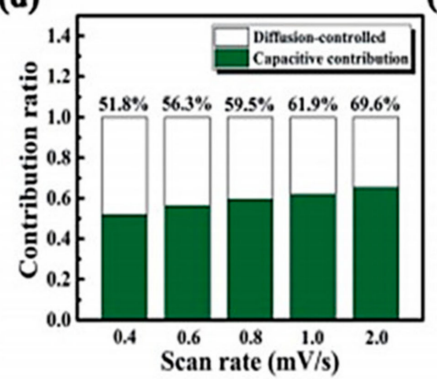

(b)

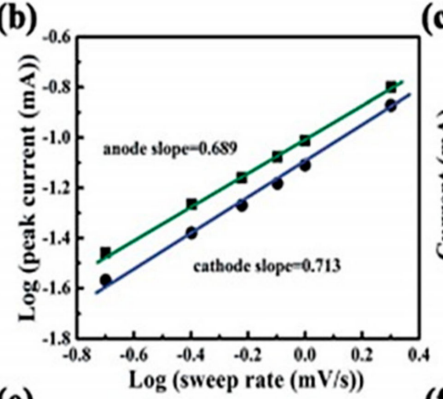

(e)

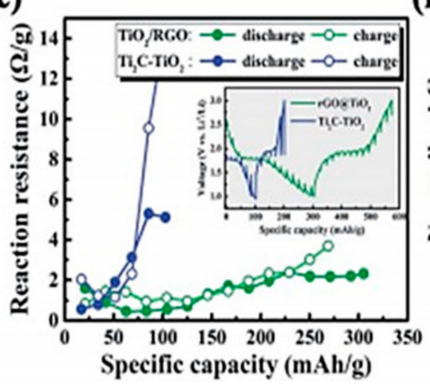

(c)

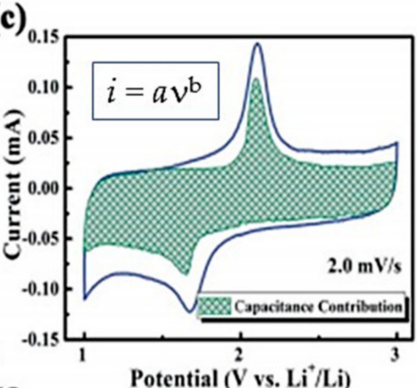

(f)

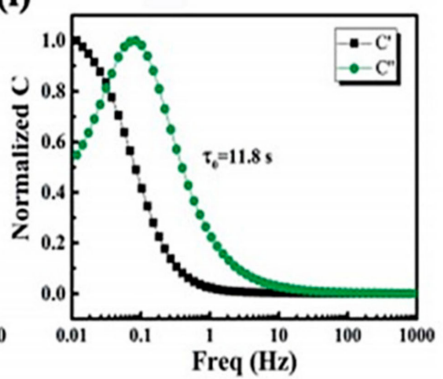

Figure 9. Quantification of the capacitive and diffusion contributions of $\mathrm{TiO}_{2} / \mathrm{rGO}$ composite. (a) CV curves at different sweep rates $\mathrm{n}$ in the range $0.2-2.0 \mathrm{mV} \mathrm{s}^{-1}$. (b) Value of the power parameter of peak currents $\left(i=a \mathrm{n}^{\mathrm{b}}\right.$ ) at different scan rates. (c) Area ratio of the CV curve at $2.0 \mathrm{mV} \mathrm{s}^{-1}$. (d) Columnar contrast chart at different scan rates. (e) Reaction resistance analysis of $\mathrm{TiO}_{2} / \mathrm{rGO}$, inset: GITT tests. (f) Bode curves of normalized real and imaginary of $\mathrm{TiO}_{2} / \mathrm{rGO}$. Reproduced with permission from [341]. Copyright 2019 The Royal Society of Chemistry.

GO can be photocatalytically reduced by the $\mathrm{TiO}_{2}$ nanoparticles under the UV illumination [344,345]. Qiu et al. [345] prepared the $\mathrm{TiO}_{2} / \mathrm{GO}$ hybrids by sonication and reduced GO into rGO using the photocatalytic property of $\mathrm{TiO}_{2}$. The suspension was illuminated under the UV light of a 1000-W exon lamp for 2-5 h producing $\mathrm{TiO}_{2}$ nanoparticles uniformly anchored on the surface of $\mathrm{rGO}$ sheets. The $\mathrm{TiO}_{2} / \mathrm{rGO}$ nanocomposites exhibited the first discharge and charge capacities of 546 and $296 \mathrm{mAh} \mathrm{g}^{-1}$ and preserved a cycling stability of $\sim 215 \mathrm{mAh} \mathrm{g}^{-1}$ at $200 \mathrm{~mA} \mathrm{~g}^{-1}$ after 100 cycles. Tong et al. [346] fabricated 3D-mesoporous $\mathrm{TiO}_{2} / \mathrm{GO}$ microspheres synthesized through an UV-assisted method of reduced graphene oxide with hydrazine. This composite possessed large surface area of $258 \mathrm{~m}^{2} \mathrm{~g}^{-1}$ and a narrow pore size of $7.8 \mathrm{~nm}$. These $\mathrm{TiO}_{2} / \mathrm{GO}$ microspheres achieved an initial discharge capacity of $220 \mathrm{mAh} \mathrm{g}^{-1}$ with $84 \%\left(\sim 185 \mathrm{mAh} \mathrm{g}^{-1}\right)$ capacity retention over 100 cycles at $0.2 \mathrm{C}$ rate, and $141 \mathrm{mAh} \mathrm{g}^{-1}$ at $1 \mathrm{C}$ rate. $\mathrm{A} 3 \mathrm{D} \mathrm{TiO}_{2}$-carbon-rGO composite was fabricated and post-treated with UV irradiation $(254 \mathrm{~nm})$ for $0.5 \mathrm{~h}$. A specific discharge capacity up to $191 \mathrm{mAh} \mathrm{g}^{-1}$ was obtained after 100 cycles at a current rate of $0.2 \mathrm{C}\left(40 \mathrm{~mA} \mathrm{~g}^{-1}\right)$ for composite with $158 \mathrm{~m}^{2} \mathrm{~g}^{-1}$ [347].

Ren et al. [348] constructed $\mathrm{TiO}_{2}$-carbon-rGO composites by anchoring $\mathrm{TiO}_{2}$ nanoparticles (10-15 $\mathrm{nm}$ in size, anatase phase) encapsulated in carbon shells onto rGO sheets (15 wt\%). This hybrid showed a BET specific surface area of $167.2 \mathrm{~m}^{2} \mathrm{~g}^{-1}$ and a typical bi-modal mesoporous structure with pore width of 3.8 and $32.5 \mathrm{~nm}$ and average pore width of $7.5 \mathrm{~nm}$ calculated using BJH model. The total pore volume with pore width from 1.7 to $300 \mathrm{~nm}$ was $0.26 \mathrm{~cm}^{3} \mathrm{~g}^{-1}$. Such a morphology useful for the facile diffusion of $\mathrm{Li}^{+}$ions in electrodes provided excellent electrochemical performance. Tested as the anode materials in Li-ion cell, the $\mathrm{TiO}_{2}$-carbon-rGO composites exhibited an initial specific discharge capacity of $188 \mathrm{mAh} \mathrm{g}^{-1}$ and a superior capacity retention of $158 \mathrm{mAh} \mathrm{g}^{-1}$ after 100 cycles at $1 \mathrm{~A} \mathrm{~g}^{-1}$ current rate. Cao et al. [89] investigated the lithium-ion insertion/extraction behavior in $\mathrm{TiO}_{2} / \mathrm{rGO}$ nanocomposites synthesized using tetrabutyl titanate $\left(\mathrm{Ti}(\mathrm{OBu})_{4}\right)$ as the titanium source via a solvothermal route as anode materials for lithium-ion batteries. The hybrid nanocomposite featured a reversible capacity of $153 \mathrm{mAh} \mathrm{g}^{-1}$ for after 100 cycles at a high charge rate of $5 \mathrm{C}\left(1000 \mathrm{~mA} \mathrm{~g}^{-1}\right)$. Madhusanka et al. [349] reported the electrochemical properties of $\mathrm{TiO}_{2} / \mathrm{rGO}$ composite prepared 
by sonication for 5 min of a water/ethanol solution containing $\mathrm{rGO}, \mathrm{TiO}_{2}$ powder, Triton X-100 surfactant, and sodium carboxymethyl cellulose. $\mathrm{TiO}_{2} / \mathrm{rGO}$ electrodes (loading of $4-6 \mathrm{mg} \mathrm{cm}^{-2}$ ) delivered a first discharge capacity of $159 \mathrm{mAh} \mathrm{g}^{-1}$ and retained $143 \mathrm{mAh} \mathrm{g}^{-1}$ after 100 cycles at current density of $100 \mathrm{~mA} \mathrm{~g}^{-1}$ with a coulombic efficiency of $99.5 \%$. Mesoporous anatase $\mathrm{TiO}_{2}$ sheets/rGO sandwich-like nanocomposites were fabricated by acid-assisted $\mathrm{Ti}(\mathrm{OBu})_{4}$ hydrolysis and subsequent thermal reduction process [350]. Three samples with different proportion of $\mathrm{rGO}$ were obtained by changing the volumes of $\mathrm{Ti}(\mathrm{OBu})_{4}$ and concentrated $\mathrm{H}_{2} \mathrm{SO}_{4}$. The optimal sample $(9.6 \mathrm{~nm}$ particle size, $\sim 43 \mathrm{~m}^{2} \mathrm{~g}^{-1}$ BET specific surface area) delivered an initial discharge capacity of $357 \mathrm{mAh} \mathrm{g}^{-1}$. The reversible lithium-storage capacity reached $161 \mathrm{mAh} \mathrm{g}^{-1}$ after 50 cycles with $\sim 70 \%$ retention at a current rate of $170 \mathrm{~mA} \mathrm{~g}^{-1}(0.5 \mathrm{C})$. Park et al. have synthesized $\mathrm{rGO}$-coated $\mathrm{TiO}_{2}$ microcones as composite anode materials via simple anodization and cyclic voltammetry [351]. The obtained $\mathrm{TiO}_{2} / \mathrm{rGO}$ hybrid showed a capacity of $157 \mathrm{mAh} \mathrm{g}^{-1}$ at $10 \mathrm{C}$ rate and sustained 1000 cycles with only $0.02 \%$ capacity fading per cycle. The hierarchically porous $\mathrm{TiO}_{2} / \mathrm{rGO}$ hybrid anode material designed by $\mathrm{Yu}$ and coworkers [352] exhibited a reversible capacity of $250 \mathrm{mAh} \mathrm{g}^{-1}$ at $1 \mathrm{C}$ rate $\left(1 \mathrm{C}=335 \mathrm{~mA} \mathrm{~g}^{-1}\right)$ in the voltage range of 1.0-3.0 V. After 1000 cycles, stable capacities of 176 and $160 \mathrm{mAh} \mathrm{g}^{-1}$ were delivered at $5 \mathrm{C}$ and 500 cycles at $10 \mathrm{C}$, respectively. An ultrathin mesoporous $\mathrm{TiO}_{2} / \mathrm{rGO}$ composite was obtained by Liang et al. via a layer-by-layer process [353]. $\mathrm{Ti}_{3} \mathrm{O}_{7}{ }^{2-}$ nanosheets obtained by exfoliation of $\mathrm{Na}_{2} \mathrm{Ti}_{3} \mathrm{O}_{7}$ were used as the precursor for $\mathrm{TiO}_{2}$. Coprecipitation of $\mathrm{GO}$ and $\mathrm{Ti}_{3} \mathrm{O}_{7}{ }^{2-}$ nanosheets in presence of $\mathrm{HCl}$ resulted in the formation of restacked $\mathrm{H}_{2} \mathrm{Ti}_{3} \mathrm{O}_{7} / \mathrm{GO}$. Then, annealing at $450{ }^{\circ} \mathrm{C}$ for $5 \mathrm{~h}$ facilitated the phase transition from $\mathrm{H}_{2} \mathrm{Ti}_{3} \mathrm{O}_{7}$ to $\mathrm{TiO}_{2}$ and the reduction of graphene oxide. The resulting mesoporous $\mathrm{TiO}_{2} / \mathrm{rGO}$ composite delivered a capacity of $350 \mathrm{mAh} \mathrm{g}^{-1}$ at a current density of $0.2 \mathrm{~A} \mathrm{~g} \mathrm{~g}^{-1}$, and a capacity of $245 \mathrm{mAh} \mathrm{g}^{-1}$ maintained over 1000 cycles at $1 \mathrm{~A} \mathrm{~g}^{-1}$.

Several studies were attempted to enhance the performance of $\mathrm{TiO}_{2} / \mathrm{rGO}$ composites by doping with nitrogen. As experimental results, both electronic and ionic transport were significantly improved $[337,354,355]$. $\mathrm{TiO}_{2} / \mathrm{N}-\mathrm{rGO}$ hybrid was prepared via a facile one-pot hydrothermal method, in which ethylene glycol and ammonia are used as the reducing agent and nitrogen precursor, respectively [354]. The $\mathrm{TiO}_{2} / \mathrm{N}-\mathrm{RGO}$ nanocomposite exhibited superior electrochemical behaviors with reversible capacity of $126.8 \mathrm{mAh} \mathrm{g}^{-1}$ at $10 \mathrm{C}$ rate and outstanding capacity retention of $118.4 \mathrm{mAh} \mathrm{g}^{-1}$ after 100 cycles. In addition to the beneficial effect on ionic and electronic transport, the nitrogen doping enhances the nucleation and growth kinetics of $\mathrm{TiO}_{2}$ nanoparticles uniformly anchored on the N-rGO surface. Li et al. [337] reported that the introduction of nitrogen on the rGO framework leads to more defects. A disordered structure is thus formed to accommodate more lithium ions. Another nitrogen-doped $\mathrm{TiO}_{2} / \mathrm{rGO}$ hybrids was synthesized by hydrothermal reaction and post-annealing at $400{ }^{\circ} \mathrm{C}$ for $3 \mathrm{~h}$ [355]. The as-prepared samples contained anatase $\mathrm{TiO}_{2}$ nanoparticles $(\sim 20 \mathrm{~nm})$ uniformly anchored on GO lamella. The $\mathrm{N}-\mathrm{TiO}_{2} / \mathrm{rGO}$ electrode delivered a discharge capacity of $318 \mathrm{mAh} \mathrm{g}^{-1}$ at $0.1 \mathrm{~A} \mathrm{~g}^{-1}$ and maintained $117 \mathrm{mAh} \mathrm{g}^{-1}$ at $5 \mathrm{~A} \mathrm{~g}^{-1}$. A high reversible capacity of $210 \mathrm{mAh} \mathrm{g}^{-1}$ was preserved after 2000 cycles at $0.5 \mathrm{~A} \mathrm{~g}^{-1}$. $\mathrm{Li}^{+}$ion diffusion coefficient evaluated from EIS measurements for $\mathrm{N}-\mathrm{TiO}_{2} / \mathrm{rGO}$ was $3.8 \times 10^{-15} \mathrm{~cm}^{2} \mathrm{~s}^{-1}$, which is higher than that of the $\mathrm{TiO}_{2} / \mathrm{rGO}$ electrode $\left(5.5 \times 10^{-16} \mathrm{~cm}^{2} \mathrm{~s}^{-1}\right)$. Electrochemical analysis finds the number of active Li-ions is increased from the formation of N-Ti-O and N-C bonds.

Ternary $\mathrm{Si}_{\mathrm{TiO}} \mathrm{Ti}_{2} @ \mathrm{rGO}$ composite with sandwich-like structure was prepared via simple sol-gel combined with graphene encapsulation process of $\mathrm{GO}$, with subsequent annealing process at $600{ }^{\circ} \mathrm{C}$ for $2 \mathrm{~h}$ in $\mathrm{N}_{2}$ atmosphere to reduce GO. The composite consisted of Si nanoparticles (spherical, $50 \mathrm{~nm}$ diameter) covered by uniform $\mathrm{TiO}_{2}$ shells during the sol-gel process to fabricate the $\mathrm{Si} @ \mathrm{TiO}_{2}$ composite, which were then encapsulated by flexible graphene sheets ( $15 \mathrm{~nm}$ thick) to produce the $\mathrm{Si} @ \mathrm{TiO}_{2} @ \mathrm{rGO}$ hybrid. Due to the synergetic effects of the stable $\mathrm{TiO}_{2}$ (anatase phase) coating and the flexible graphene network, the as-synthetized $\mathrm{Si} @ \mathrm{TiO}_{2} @ \mathrm{rGO}$ anode delivered a charge specific capacity of $1135 \mathrm{mAh} \mathrm{g}{ }^{-1}$ under current rate of $0.2 \mathrm{~A} \mathrm{~g}^{-1}$ after 100 cycles with an initial CE of $76.9 \%$. A charge specific capacity of $568 \mathrm{mAh} \mathrm{g}^{-1}$ was retained at current rate of $3 \mathrm{~A} \mathrm{~g}^{-1}$ (Figure 10). Results of EIS measurements in the $100^{\text {th }}$ cycle showed higher diffusion coefficient of lithium ion of $8.0 \times 10^{-11} \mathrm{~cm}^{2} \mathrm{~s}^{-1}$ than $D_{\mathrm{Li}}+=5.7 \times$ 
$10^{-12} \mathrm{~cm}^{2} \mathrm{~s}^{-1}$ for the fresh $\mathrm{Si} @ \mathrm{TiO}_{2} @ \mathrm{rGO}$ anode, which suggests a better lithium-ion transfer after the initial cell formation [356]. Electrochemical performance of $\mathrm{TiO}_{2} / \mathrm{rGO}$ composite anodes for LIBs from the recent literature are summarized in Table 6.
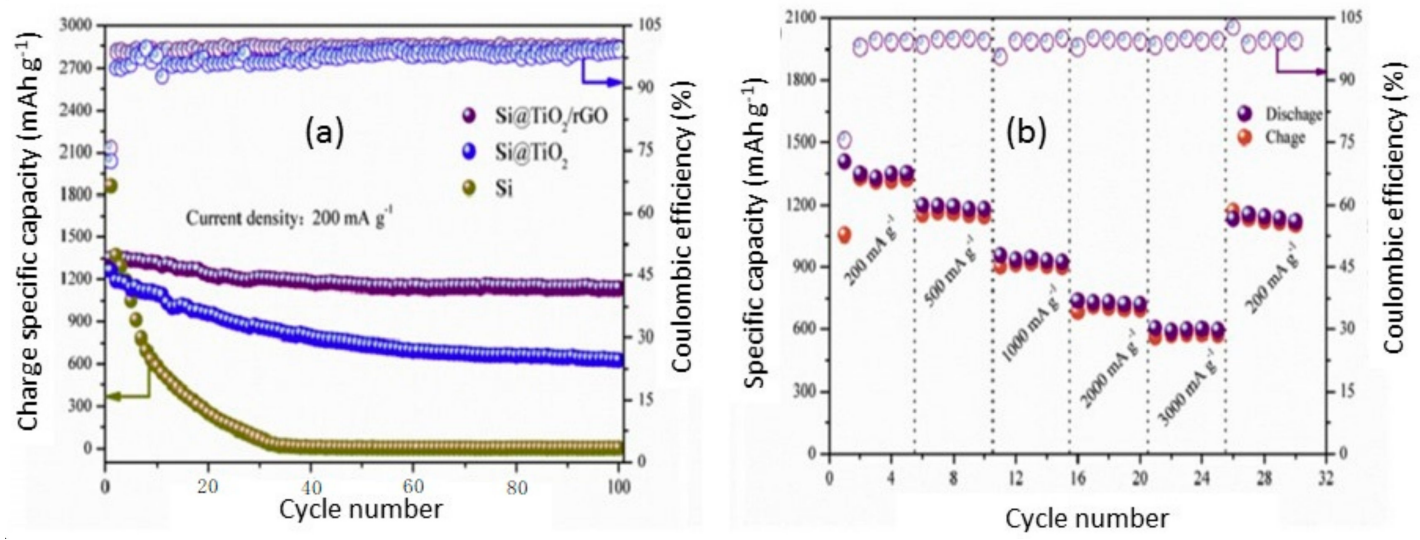

Figure 10. (a) Cyclability of $\mathrm{Si}_{\mathrm{TiO}} @ \mathrm{TGO}, \mathrm{Si} @ \mathrm{TiO}_{2}$ and $\mathrm{Si}$ anodes tested at current rate of $0.2 \mathrm{~A} \mathrm{~g}^{-1}$. (b) Rate capability and coulombic efficiency of the $\mathrm{Si} @ \mathrm{TiO}_{2} @ \mathrm{rGO}$ anode. Reproduced with permission from ref. [356]. Copyright 2020 Elsevier.

Table 6. Electrochemical properties of $\mathrm{TiO}_{2} / \mathrm{GO}$ composites. Relevant cycle number is given in brackets.

\begin{tabular}{|c|c|c|c|c|}
\hline Material & Synthesis & $\begin{array}{l}\text { Specific Capacity } \\
\left(m A h g^{-1}\right)\end{array}$ & $\begin{array}{l}\text { Current Rate } \\
\left(\mathrm{mA} \mathrm{g}^{-1}\right)\end{array}$ & Ref. \\
\hline $\mathrm{TiO}_{2} / \mathrm{rGO}$ & hydrothermal $160^{\circ} \mathrm{C} / 12 \mathrm{~h}$ & 112 & $1700(100)$ & {$[334]$} \\
\hline $\mathrm{TiO}_{2} / \mathrm{GO}$ & UV photocatalysis & 130 & $200(100)$ & [345] \\
\hline $\mathrm{TiO}_{2} / \mathrm{rGO}$ & UV photocatalysis & 215 & $200(100)$ & [345] \\
\hline $\mathrm{TiO}_{2} / \mathrm{N}$-doped rGO & hydrothermal $200^{\circ} \mathrm{C} / 20 \mathrm{~h}$ & 187 & - & [337] \\
\hline $\mathrm{TiO}_{2} / \mathrm{rGO}$ & solvothermal with $\mathrm{Ti}(\mathrm{OBu})_{4}$ & 153 & $1000(100)$ & [89] \\
\hline $\mathrm{TiO}_{2} / \mathrm{rGO}$ & hydrothermal $150^{\circ} \mathrm{C} / 14 \mathrm{~h}$ & 236 & $100(100)$ & {$[338]$} \\
\hline $\mathrm{TiO}_{2} / \mathrm{rGO}$ & hydrothermal $180^{\circ} \mathrm{C} / 20 \mathrm{~h}$ & 235 & $200(1000)$ & [327] \\
\hline $\mathrm{TiO}_{2}$-carbon-rGO & hydrothermal $160^{\circ} \mathrm{C} / 24 \mathrm{~h}$ & 158 & $1000(100)$ & [348] \\
\hline $\mathrm{TiO}_{2} / \mathrm{rGO}$ & sonication for $5 \mathrm{~min}$ & 143 & $100(100)$ & [349] \\
\hline $\mathrm{R}-\mathrm{TiO}_{2} / \mathrm{rGO}$ & hydrothermal $180^{\circ} \mathrm{C} / 12 \mathrm{~h}$ & 90 & $1680(1000)$ & [336] \\
\hline $\mathrm{TiO}_{2} / \mathrm{rGO}$ & hydrothermal $160^{\circ} \mathrm{C} / 16 \mathrm{~h}$ & 130 & $1680(1000)$ & [341] \\
\hline $\mathrm{TiO}_{2} / \mathrm{rGO}$ & hydrothermal $180^{\circ} \mathrm{C} / 12 \mathrm{~h}$ & 180 & $500(2000)$ & [329] \\
\hline $\mathrm{TiO}_{2}$-carbon-rGO & UV photocatalysis $(254 \mathrm{~nm})$ & 191 & $40(100)$ & [347] \\
\hline $\mathrm{TiO}_{2} / \mathrm{rGO}$ & thermal reduction & 161 & $170(50)$ & {$[350]$} \\
\hline $\mathrm{TiO}_{2}(\mathrm{~B})-\mathrm{CNTs}-\mathrm{GO}$ & hydrolysis + hydrothermal & 190 & $1 C(200)$ & {$[340]$} \\
\hline $\mathrm{TiO}_{2} / \mathrm{rGO}(9.9 \%$ rGO$)$ & hydrothermal + annealing & 254 & $168(600)$ & [333] \\
\hline $\mathrm{TiO}_{2} / \mathrm{rGO}(10 \% \mathrm{rGO})$ & aerosol-assisted spray-drying & 174 & $1 C(200)$ & [339] \\
\hline $\mathrm{N}$-doped $\mathrm{TiO}_{2} / \mathrm{rGO}$ & hydrothermal + annealing & 210 & $100(2000)$ & {$[355]$} \\
\hline $\mathrm{Si}_{\mathrm{TiO}} @ \mathrm{rGO}$ & sol-gel & 1135 & $200(100)$ & [356] \\
\hline $\mathrm{TiO}_{2} / \mathrm{rGO}$ & solvothermal alcoholysis & 176 & $1675(1000)$ & [352] \\
\hline $\mathrm{TiO}_{2} / \mathrm{rGO}$ & microwave hydrothermal process & 250 & $0.2 C(200)$ & [342] \\
\hline $\mathrm{TiO}_{2} / \mathrm{rGO}$ & coprecipitation $\mathrm{Ti}_{3} \mathrm{O}_{7}{ }^{2-}+\mathrm{GO}$ & 245 & $1000(1000)$ & {$[353]$} \\
\hline
\end{tabular}

\subsection{2. $\mathrm{Li}_{4} \mathrm{Ti}_{5} \mathrm{O}_{12}$-Based Composites}

$\mathrm{Li}_{4} \mathrm{Ti}_{5} \mathrm{O}_{12}$ (LTO) can interact with $\mathrm{Li}$ ions by an intercalation/deintercalation process up to $3 \mathrm{Li}$ delivering a theoretical capacity of $175 \mathrm{mAh} \mathrm{g}^{-1}$ with negligible volume expansion $(<0.2 \%)$. However, this spinel framework has a poor electrical conductivity, which can be mitigated through the introduction of carbonaceous material $[357,358]$.

Since 2011, great efforts have been devoted for the in-situ synthesis of LTO anode materials combined with graphene-based compounds. For example, Shen et al. [359] employed a three-step process with the hydrolysis of tetrabutyl titanate in the presence of $\mathrm{GO}$ to produce $\mathrm{TiO}_{2} / \mathrm{GO}$ hybrid, which was then transformed into Li-Ti-O/rGO by a hydrothermal method, and finally to LTO/rGO by a post-heating treatment. It is noteworthy that the specific capacity of $82.7 \mathrm{mAh} \mathrm{g}^{-1}$ was obtained 
at a high rate of 60C. Kim et al. [360] utilized a similar microwave assisted, two-step method with titanium ethoxide, $\mathrm{LiOH}$, and GO to obtain $\mathrm{Li}-\mathrm{Ti}-\mathrm{O} / \mathrm{rGO}$ hybrid, which was then transformed to LTO/rGO by post annealing. The phase-pure LTO/rGO nanocomposite delivered a reversible capacity of $168 \mathrm{~mA} \mathrm{~h} \mathrm{~g}^{-1}$ at $1 \mathrm{C}$-rate and a remarkable rate capability with $59 \%$ capacity retention at $50 \mathrm{C}$-rate.

Chen et al. [361] prepared a nanohybrid electrode of mesoporous single crystalline $\mathrm{Li}_{4} \mathrm{Ti}_{5} \mathrm{O}_{12}$ deposited on rGO (MSCs-LTO/rGO) via a simple hydrothermal reaction of $\mathrm{TiO}_{2} / \mathrm{rGO}$ and $\mathrm{LiOH}$ with subsequent annealing in Ar at $600{ }^{\circ} \mathrm{C}$. This MSCs-LTO/rGO anode yielded a specific capacity of $171 \mathrm{mAh} \mathrm{g}^{-1}$ at $0.5 \mathrm{C}$ rate with CE of $95.6 \%$, a rate capability of $132 \mathrm{mAh} \mathrm{g}^{-1}$ at high rate of $40 \mathrm{C}$ and $85 \%$ capacity retention after 2000 cycles. A scalable synthesis of LTO/rGO composite was proposed by $\mathrm{Ni}$ et al. [362]. The as-prepared hybrid presented LTO nanoparticles uniformly immobilized on the rGO sheets and showed outstanding performance, i.e., good cycle ability and excellent rate capability with specific capacities of 154 and $149 \mathrm{mAh} \mathrm{g}^{-1}$ at 10C and 20C rate, respectively. Cycle stability of LTO/rGO after 200 cycles at 5C (98.9\% capacity retention) was much better than that of bare LTO (93\%). Di et al. fabricated an LTO/rGO through a simple hydrothermal process, which demonstrated a capacity retention of $86.6 \%$ after 2000 cycles at 5C [363]. The capacity delivered at 50C and 100C were still 132 and $97.5 \mathrm{mAh} \mathrm{g}^{-1}$, respectively. Chen et al. reported that even a small amount of rGO $(1.2 \mathrm{wt} \%)$ effectively prevents grain growth and particles aggregation of LTO and enhances the specific surface area of the anode material [364]. The Lil|LTO/rGO half-cell could deliver the specific capacity of $187 \mathrm{mAh} \mathrm{g}^{-1}$ at $1 \mathrm{C}$ rate and the high-rate discharge capacity of $128 \mathrm{mAh} \mathrm{g}^{-1}$ at $80 \mathrm{C}$ operating for 2000 cycles. Zhang et al. fabricated a $\mathrm{Li}_{4} \mathrm{Ti}_{5} \mathrm{O}_{12}$ microspheres/rGO composite by hydrolysis of titanium butoxide with subsequent hydrothermal reaction at $180^{\circ} \mathrm{C}$ for $36 \mathrm{~h}$ of $\mathrm{TiO}_{2}$ precursor with $\mathrm{GO}$ and $\mathrm{LiOH}$, followed by a heat treatment at $600{ }^{\circ} \mathrm{C}$ in Ar atmosphere [365]. The $3 \mathrm{wt} \%$ rGO-coated LTO composite presented a high reversible Li-ion insertion capability with a specific discharge capacity of $131.6 \mathrm{mAh} \mathrm{g}^{-1}$ at $5 \mathrm{C}$ rate and $97 \%$ capacity retention after 500 cycles. A porous $\mathrm{Li}_{4} \mathrm{Ti}_{5} \mathrm{O}_{12} / N$-doped rGO composites was synthesized, while using cyanamide as the nitrogen source prevented the rGO restacking and increased the electronic conductivity to $1.6 \mathrm{~S} \mathrm{~cm}^{-1}$ [366]. The $\mathrm{Li}_{4} \mathrm{Ti}_{5} \mathrm{O}_{12} / N$-doped rGO composite with a BET specific surface area of $35.8 \mathrm{~m}^{2} \mathrm{~g}^{-1}$ demonstrated a specific discharge capacity of $117.8 \mathrm{mAh} \mathrm{g}^{-1}$ at 30C rate. The work by Cao et al. [367] shows that LTO/rGO composite grown via one-pot way (hydrothermal process at $180^{\circ} \mathrm{C}$ for $36 \mathrm{~h}$ ) displays higher rate capacity and larger discharge capacity than the bare LTO sample. The small rGO ratio-containing composite $(\sim 6.2 \mathrm{wt} \%)$ delivered a reversible specific capacity of $196.4 \mathrm{mAh} \mathrm{g}^{-1}$ at $1 \mathrm{C}$ rate and good cycle ability with $98.1 \%$ retention after 100 cycles. The rate capability tests showed discharge capacities of 175, 167, and $160 \mathrm{mAh} \mathrm{g}^{-1}$ at $10 \mathrm{C}, 15 \mathrm{C}$, and 20C, respectively. After 500 cycles at 20C, the discharge capacity retained $154.5 \mathrm{mAh} \mathrm{g}^{-1}$ (96.5\% retention). Ge et al. [368] reported the synthesis of LTO/GO and LTO/rGO composites by a facile one-step hydrothermal route at $180^{\circ} \mathrm{C}$ for $24 \mathrm{~h}$ using $\mathrm{Ti}\left(\mathrm{SO}_{4}\right)_{2}$ raw material. The reduction of $\mathrm{GO}$ to rGO was realized by the hydroxyl groups of glucose, which prevented LTO particle aggregation and led to a mesoporous structure $\left(\sim 5 \mathrm{~nm}\right.$ pore size). The reversible specific capacity of $193 \mathrm{mAh} \mathrm{g}^{-1}$ at $0.5 \mathrm{C}$ rate was delivered by this nanocomposite anode and a capacity of $168 \mathrm{mAh} \mathrm{g}^{-1}$ was retained at superior rate of $30 \mathrm{C}$ (Figure 11). 
(a)
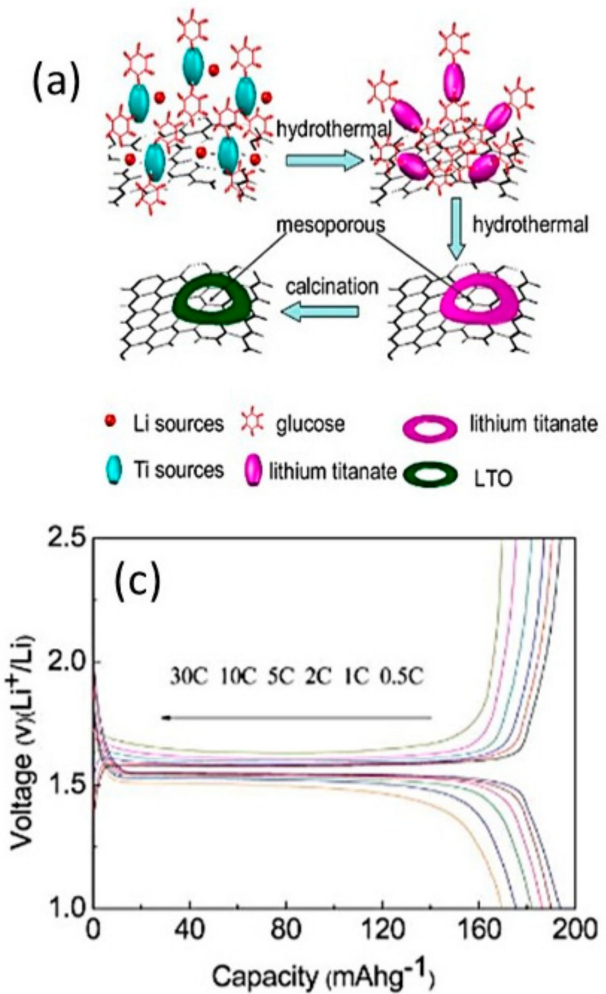
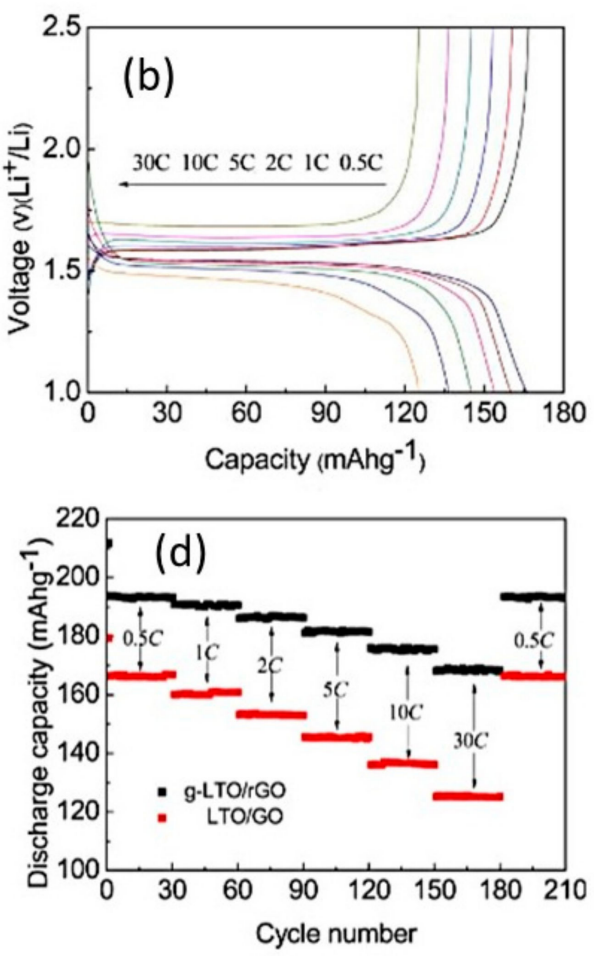

Figure 11. (a) Schematic illustration of the synthesis of LTO/rGO composite. (b) Galvanostatic charge-discharge profiles of LTO/GO at different current densities. (c) Galvanostatic charge-discharge profiles of LTO/rGO at different current densities. (d) Comparison of the rate capabilities of LTO/GO and LTO/rGO composites from 0.5 to 30C. Reproduced with permission of [368]. Copyright 2016 American Chemical Society.

The LTO/rGO composite with a "fishnet-like" hierarchical porous structure was fabricated via a gas-foaming method [369]. LTO particles of 50-100 nm were obtained with the $\mathrm{NH}_{4} \mathrm{Cl}$ concentration of $1 \mathrm{mg} \mathrm{mL}-1$. Electrochemical tests demonstrated a specific capacity of $176.6 \mathrm{mAh} \mathrm{g}^{-1}$ at a rate of $1 \mathrm{C}$, a rate capability of 167 and $143 \mathrm{mAh} \mathrm{g}^{-1}$ at $3 \mathrm{C}$ and 10C, respectively, and a capacity retention of $95.4 \%$ after 100 cycles at 10C. Pender et al. [370,371] reported the fabrication and electrochemical performance of metal-foil free $\mathrm{Li}_{4} \mathrm{Ti}_{5} \mathrm{O}_{12}$ (LTO) and $\mathrm{LiNi}_{1 / 3} \mathrm{Mn}_{1 / 3} \mathrm{Co}_{1 / 3} \mathrm{O}_{2}$ (NMC) electrodes supported on conductive and porous reduced graphene oxide/poly(acrylic acid) (rGO-PAA) aerogels. This 3D nanocomposite had a low density $\left(\sim 5 \mathrm{mg} \mathrm{cm}^{-3}\right)$ and high porosity (99.6\% void space) [370]. When applied as a free-standing, 3D current collector in LIBs, the highly porous rGO-PAA substrate increased the effective electrode-electrolyte contact area 2.5 - fold $\left(16 \mathrm{mg} \mathrm{cm}^{-2}\right.$ loading) by increasing the electrode surface roughness and thus improving the lithiation/delithiation kinetics of a commercial LFP cathode [372]. The use of rGO-PAA instead of conventional metal-foil (CMF) showed a $25 \%$ increase in energy density over similar electrodes built with CMF current collector, i.e., high volumetric energy densities of $1723 \mathrm{Wh} \mathrm{L}^{-1}$ for NMC and $625 \mathrm{Wh} \mathrm{L}^{-1}$ for LTO [371].

Recently, an in-situ supramolecular self-assembly assisted synthesis combining spray drying and high-temperature calcination was employed to prepare $\mathrm{Li}_{4} \mathrm{Ti}_{5} \mathrm{O}_{12}$-carbon-rGO microspheres for LIBs. During the sol formation, GO was connected with $\mathrm{Ti}(\mathrm{OH})_{4}$ coated by polydopamine [373]. The as-prepared composite consisted of small size LTO particles $(\sim 50 \mathrm{~nm})$ wrapped in 3D rGO nanosheets. The LTO/C/rGO hybrid anode exhibited a reversible capacity of $184 \mathrm{mAh} \mathrm{g}^{-1}$ at $1 \mathrm{C}$ rate and a capacity retention of $94.5 \%$ after 500 cycles at $20 \mathrm{C}$ rate. These results compared well with those reported by Chen et al. on LTO/CNTs/graphene composite prepared by ball-milling, which exhibits a discharge capacity of $132 \mathrm{mAh} \mathrm{g}^{-1}$ at 20C rate [374]. 
More recently, the ternary microspherical C/LTO/rGO, which consisted of ethylene glycol-derived in-situ carbon-coated $\mathrm{Li}_{4} \mathrm{Ti}_{5} \mathrm{O}_{12}$ nanoparticles and $\mathrm{rGO}$ sheets, was synthesized by polyol-mediated spray drying method [375]. The as-fabricated C/LTO/rGO composite tested as anode material for LIBs showed $94 \%$ capacity retention after 3000 cycles at $10 \mathrm{C}$ and $93 \%$ capacity retention after 1000 cycles at $60{ }^{\circ} \mathrm{C}$. This electrode was also studied as anode for sodium-ion batteries showing $95 \%$ capacity retention after 1000 cycles at $5 \mathrm{C}$ for $\mathrm{Na}^{+}$storage at room temperature. An LTO/rGO nanolayered composite was synthesized by electrophoretical co-deposition onto $\mathrm{Cu}$ substrate using a suspension of 2D-lithium titanate hydrate and GO nanosheets followed by a controlled annealing at $600{ }^{\circ} \mathrm{C}$ for $6 \mathrm{~g}$ using a ramping temperature of $5{ }^{\circ} \mathrm{C} \mathrm{min}^{-1}$ [376]. Galvanostatic experiments performed at $1 \mathrm{C}$ $\left(175 \mathrm{~mA} \mathrm{~g}^{-1}\right)$ showed a retention capacity of $\sim 135 \mathrm{mAh} \mathrm{g}^{-1}$ after 150 cycles. The rate capability test demonstrated a specific capacity of $50 \mathrm{mAh} \mathrm{g}^{-1}$ at high rate of $50 \mathrm{C}$.

\subsection{Iron-Based Oxide Composites}

\subsection{1. $\mathrm{Fe}_{3} \mathrm{O}_{4}$-Based Composites}

Magnetite $\left(\mathrm{Fe}_{3} \mathrm{O}_{4}\right)$ proved to be a rechargeable conversion electrode material that reacts with $8 \mathrm{Li}$ ions per formula unit leading a theoretical specific capacity of about $926 \mathrm{mAh} \mathrm{g}^{-1}$ [377]. While cells using iron oxides present voltage hysteresis from 0.7 to $1.0 \mathrm{~V}$, the use of rGO reduces the overpotential to $\sim 0.7 \mathrm{~V}$. In 2010 , the study of a micro-structured graphene nanosheets $/ \mathrm{Fe}_{3} \mathrm{O}_{4}$ composite has shown the superior performance with the addition of graphene with a reversible specific capacity approaching $1026 \mathrm{mAh} \mathrm{g}^{-1}$ after 30 cycles at $35 \mathrm{~mA} \mathrm{~g}^{-1}$ and $580 \mathrm{mAh} \mathrm{g}^{-1}$ after 100 cycles at $700 \mathrm{~mA} \mathrm{~g}^{-1}$ [62]. Since 2011, numerous works have been devoted to the investigation of GO-ferrite composite. $\mathrm{Fe}_{3} \mathrm{O}_{4} / \mathrm{rGO}$ composites are not only mostly synthesized using the popular hydrothermal method with subsequent annealing process [378-382] but also employing other techniques such as chemical precipitation [383-385], one-pot microwave reduction [386], electrophoretic deposition [387], and redox reaction [388].

$\mathrm{Li}$ et coworkers prepared $\mathrm{Fe}_{3} \mathrm{O}_{4} / \mathrm{rGO}$ nanocomposites through a chemical co-precipitation of $\mathrm{Fe}^{2+}$ and $\mathrm{Fe}^{3+}$ in the presence of $\mathrm{GO}$ in alkaline solution. After a thermal reduction, the composite was composed of $\mathrm{Fe}_{3} \mathrm{O}_{4}$ nanoparticles homogeneously dispersed on the rGO sheet surface [383]. Tested in half-cell, this composite displayed a reversible capacity of about $200 \mathrm{mAh} \mathrm{g}^{-1}$ even at a high charge/discharge rate of $10 \mathrm{C}\left(9260 \mathrm{~mA} \mathrm{~g}^{-1}\right)$. The $\mathrm{rGO} / \mathrm{Fe}_{3} \mathrm{O}_{4} \| \mathrm{LiNi}_{1 / 3} \mathrm{Mn}_{1 / 3} \mathrm{Co}_{1 / 3} \mathrm{O}_{2}$ full-cell exhibited a capacity of $80 \mathrm{mAh} \mathrm{g}^{-1}$ when discharged at $0.2 \mathrm{C}$ rates over 10 cycles. Zhu et al. [384] reported the fabrication of $\mathrm{Fe}_{2} \mathrm{O}_{3} / \mathrm{rGO}$ composite using a facile two-step synthesis by homogeneous co-precipitation of $\mathrm{FeCl}_{3}$ in a suspension of $\mathrm{GO}$ platelets with urea, with subsequent reduction of the $\mathrm{GO}$ with hydrazine under microwave irradiation. The composite has a curled morphology consisting of a thin, wrinkled, "paperlike" structure. Such rGO platelets decorated with $\mathrm{Fe}_{2} \mathrm{O}_{3}$ nanoparticles ( $60 \mathrm{~nm}$ in diameter) showed discharge and charge capacities of $\sim 1355$ and $982 \mathrm{mAh} \mathrm{g}^{-1}$, respectively, based on the total mass of the composite, at a current density of $100 \mathrm{~mA} \mathrm{~g}^{-1}$ over 50 cycles. A three-dimensional $\mathrm{Fe}_{3} \mathrm{O}_{4} / \mathrm{rGO}$ composite was constructed by anchoring $\mathrm{Fe}_{3} \mathrm{O}_{4}$ nanoparticles encapsulated within carbon shells onto reduced graphene oxide sheet [58]. The two-step synthesis consisted in the mixture of an aqueous solutions of $\mathrm{Fe}\left(\mathrm{NO}_{3}\right)_{3} \cdot 6 \mathrm{H}_{2} \mathrm{O}$ and polyvinylpyrrolidone (PVP, $M_{\mathrm{W}}=40,000$ ) with the aqueous suspension of graphene oxide (GO) and an aqueous solution of glucose and urotropine (1:1) followed by a calcination to $500{ }^{\circ} \mathrm{C}$ in Ar flow. The final black powders exhibit a BET specific surface area of $104.2 \mathrm{~m}^{2} \mathrm{~g}^{-1}$. This $\mathrm{Fe}_{3} \mathrm{O}_{4} / \mathrm{rGO}$ composite, tested in Li half-cell, displayed an initial specific capacity of $1426 \mathrm{mAh} \mathrm{g}^{-1}$ and superior reversible capacity of $842 \mathrm{mAh} \mathrm{g}^{-1}$ after 100 cycles at $200 \mathrm{~mA} \mathrm{~g}^{-1}$ current rate.

$\mathrm{A} \mathrm{Fe}_{3} \mathrm{O}_{4} / \mathrm{rGO}$ composite was fabricated by a microwave-assisted combustion synthesis of porous $\mathrm{Fe}_{3} \mathrm{O}_{4}$ particles followed by decoration of $\mathrm{Fe}_{3} \mathrm{O}_{4}$ by rGO. The material was porous with specific surface area and pore volume of $81.87 \mathrm{~m}^{2} \mathrm{~g}^{-1}$ and $0.16 \mathrm{~cm}^{3} \mathrm{~g}^{-1}$, respectively [389]. Electrochemical results revealed a reversible capacity of 612,543 , and $446 \mathrm{mAh} \mathrm{g}^{-1}$ at current rates of $1 \mathrm{C}, 3 \mathrm{C}$, 
and $5 \mathrm{C}$, respectively, with a coulombic efficiency of $98 \%$ after 50 cycles, which emphasized the importance of the composite porosity and the improved electronic conductivity by rGO grafting. A $\mathrm{Fe}_{3} \mathrm{O}_{4} / \mathrm{rGO}$ composite was prepared by Liang et al. via coprecipitation, with $\mathrm{Fe}_{3} \mathrm{O}_{4}$ nanoparticles of size $9 \mathrm{~nm}$ [390]. As an anode containing $44.9 \mathrm{wt} \% \mathrm{Fe}_{3} \mathrm{O}_{4}$, it delivered a capacity of $300 \mathrm{mAh} \mathrm{g}^{-1}$ at $1 \mathrm{~A} \mathrm{~g}^{-1}$ after 100 cycles. Kumar et al. [386] designed and synthesized an interconnected hybrid network constituted by faceted $\mathrm{Fe}_{3} \mathrm{O}_{4}$ nanoparticles embedded in 3D rGO nanosheets by one-pot microwave approach. The electrochemical properties of these as-synthesized $\mathrm{Fe}_{3} \mathrm{O}_{4} / \mathrm{rGO}$ hybrids were analyzed by cyclic voltammetry, galvanostatic charge/discharge measurements, and electrochemical impedance spectroscopy. These hybrids demonstrated superior performance as electrostatic capacitors (ESC) with a specific capacitance of $455 \mathrm{~F} \mathrm{~g}^{-1}$ at the scan rate of $8 \mathrm{mV} \mathrm{s}^{-1}$. Moreover, the 3D composite exhibited good cycling stability with a retention of $91.4 \%$ up to 9600 cycles. Liang et al. [391] investigated the effect of $\mathrm{Fe}_{3} \mathrm{O}_{4}$ loading on the cycling behavior of $\mathrm{Fe}_{3} \mathrm{O}_{4} / \mathrm{rGO}$ hybrid anode for LIBs. The composite was prepared by co-precipitation method using $\mathrm{Fe}_{3} \mathrm{O}_{4}$ nanoparticles (grain size of ca. $9 \mathrm{~nm}$ ) and different amount of GO followed by reduction. The best cycling capacity of $300 \mathrm{mAh} \mathrm{g}^{-1}$ at $1 \mathrm{Ag}^{-1}$ current density was obtained after 100 cycles for the $\mathrm{Fe}_{3} \mathrm{O}_{4} / \mathrm{rGO}$ composite electrode containing $44.9 \mathrm{wt} \% \mathrm{Fe}_{3} \mathrm{O}_{4}$. $\mathrm{Fe}(\mathrm{OH})_{3}$ nanoparticles were embedded in $\mathrm{rGO}$ nanosheets via a pre-reduction with hydrazine followed by a hydrothermal process at $180{ }^{\circ} \mathrm{C}$ for $12 \mathrm{~h}$ and a subsequent heating at $500^{\circ} \mathrm{C}$ for $2 \mathrm{~h}$ in an $\mathrm{Ar}$ atmosphere with a heating rate of $5 \mathrm{C} \mathrm{min}^{-1}$, to yield $\mathrm{Fe}_{3} \mathrm{O}_{4} / \mathrm{rGO}$ composite with $\mathrm{Fe}_{3} \mathrm{O}_{4}$ nanoparticles of $\sim 6 \mathrm{~nm}$ in size. The as-prepared samples showed a uniform porous morphology with a high BET specific surface area of $114.7 \mathrm{~m}^{2} \mathrm{~g}^{-1}$. Galvanostatic charge-discharge measurements showed that the $\mathrm{Fe}_{3} \mathrm{O}_{4} / \mathrm{rGO} \| \mathrm{Li}$ half-cell delivers a reversible specific capacity of $1108 \mathrm{mAh} \mathrm{g}^{-1}$ at a current density of $0.5 \mathrm{~A} \mathrm{~g}^{-1}$ even after 400 cycles and maintains a reversible capacity of $593 \mathrm{mAh} \mathrm{g}^{-1}$ at $5 \mathrm{~A} \mathrm{~g}^{-1}$ current rate [378]. The $\mathrm{Fe}_{3} \mathrm{O}_{4} / \mathrm{rGO}$ composites consisting of well-crystallized $\mathrm{Fe}_{3} \mathrm{O}_{4}$ nanoparticles (10-30 nm in diameter) are tightly and homogeneously anchored on the flexible graphene substrate were synthesized through a redox reaction between highly oxidized $\mathrm{GO}$ and ferrous salt $\left(\mathrm{FeSO}_{4} \cdot 4 \mathrm{H}_{2} \mathrm{O}\right)$ under basic atmosphere (ammonia), followed by a stabilization treatment ranging from 5 min to $5 \mathrm{~h}$ [388]. The optimized $\mathrm{Fe}_{3} \mathrm{O}_{4} / \mathrm{rGO}$ composite obtained after 2-h annealing delivers a reversible capacity of $1024 \mathrm{mAh} \mathrm{g}^{-1}$ at $1 \mathrm{~A} \mathrm{~g}^{-1}$ current rate and retains $584 \mathrm{mAh} \mathrm{g}^{-1}$ at $5 \mathrm{~A} \mathrm{~g}^{-1}$ even after 450 cycles (Figure 12). A super-mesoporous $\mathrm{Fe}_{3} \mathrm{O}_{4} / \mathrm{rGO}$ anode material was prepared by a poly(methacrylic acid) (PMAA)-induced self-assembly process, which provided a sample with high porosity by optimizing the dispersion state of PMAA-stabilized $\mathrm{Fe}_{3} \mathrm{O}_{4} / \mathrm{GO}$ sheets at different surrounding $\mathrm{pH}$ values. The mesoporous composite showed a high specific surface area of $338.8 \mathrm{~m}^{2} \mathrm{~g}^{-1}$ with a large amount of $10-40 \mathrm{~nm}$ mesopores. The corresponding $\mathrm{Fe}_{3} \mathrm{O}_{4} / \mathrm{rGO}$ anode delivered specific-charge capacity of $740 \mathrm{mAh} \mathrm{g}^{-1}$ after 100 cycles at $0.5 \mathrm{~A} \mathrm{~g}^{-1}$ and decreases to $200 \mathrm{mAh} \mathrm{g}^{-1}$ at $10 \mathrm{~A} \mathrm{~g}^{-1}$ [391]. 

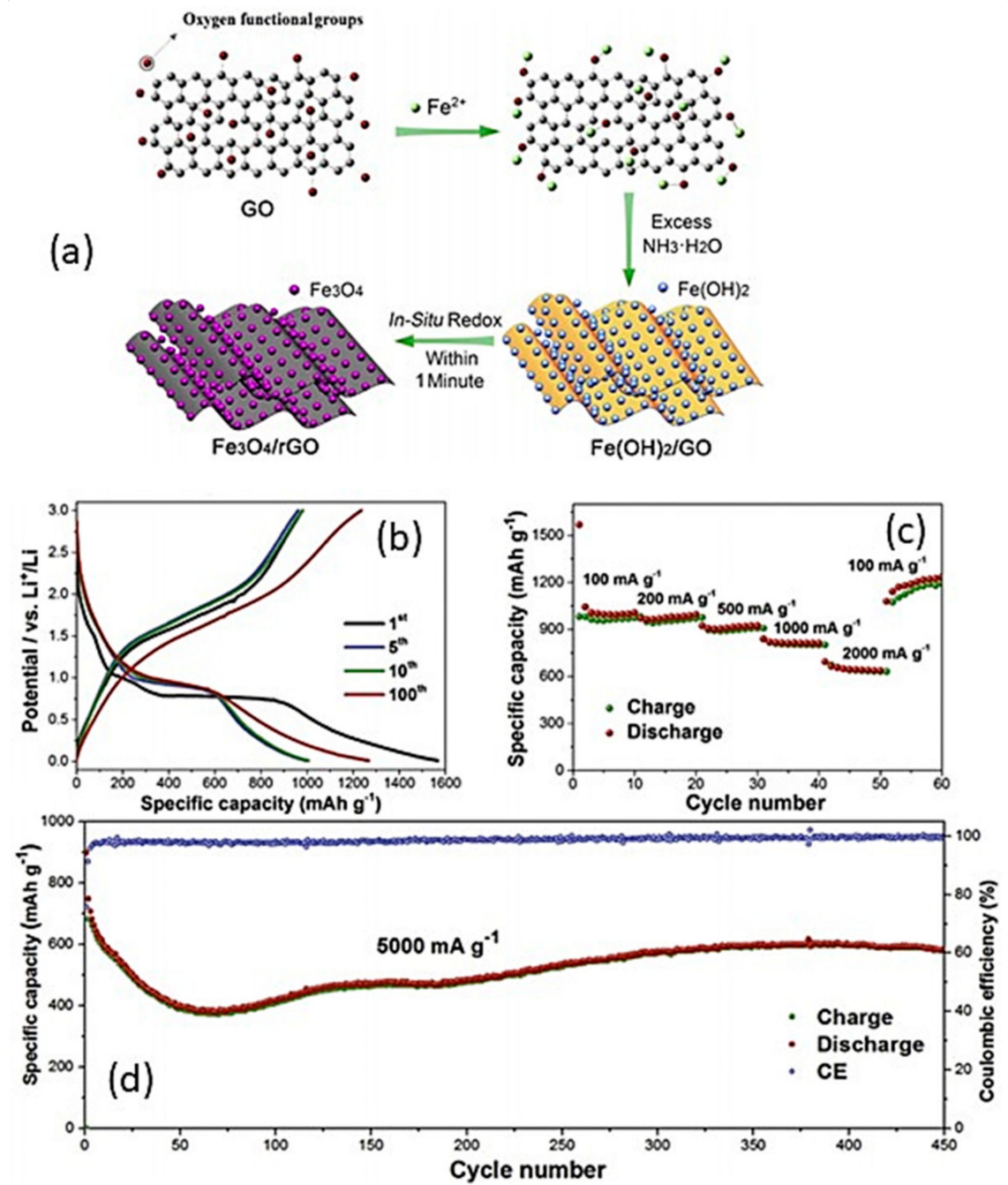

Figure 12. (a) Schematic illustration of the procedure for the synthesis of $\mathrm{Fe}_{3} \mathrm{O}_{4} / \mathrm{rGO}$ composites. (b) Charge-discharge profiles of $\mathrm{Fe}_{3} \mathrm{O}_{4} / \mathrm{rGO} \|$ Li cell performed at $1 \mathrm{~A} \mathrm{~g}^{-1}$ current rate with the composite anode obtained after 2-h annealing. (c) Rate capability. (d) Long-term cyclic capability at a current density of $5 \mathrm{~mA} \mathrm{~g}^{-1}$. Reproduced with permission form [388]. Copyright 2018 Elsevier.

Several studies are related to Fe-based ternary composite electrodes showing superior electrochemical properties. The $\mathrm{Fe}_{3} \mathrm{O}_{4} / \mathrm{CNTs} / \mathrm{rGO}$ composite electrode as a binder-free anode was prepared by electrophoretic deposition. This robust sandwich-like architecture consisted of $\mathrm{Fe}_{3} \mathrm{O}_{4}$ nanoparticles interconnected by CNTs between rGO layers [387]. The resultant $\mathrm{Fe}_{3} \mathrm{O}_{4} / \mathrm{CNTs} / \mathrm{rGO}$ hybrid electrode demonstrated enhanced electrochemical properties with high reversible capacity of $540 \mathrm{mAh} \mathrm{g}^{-1}$ at a high current density of $10 \mathrm{~A} \mathrm{~g}^{-1}$, and a remarkable capacity retention of $1080 \mathrm{mAh} \mathrm{g}^{-1}$ after 450 cycles at $1 \mathrm{~A} \mathrm{~g}^{-1}$. Xiao et al. [392] constructed a multilayered composite $\mathrm{rGO} / \mathrm{Fe}_{3} \mathrm{O}_{4} @$ polydopamine (PDA) hydrogel, in which the PDA layer plays the role of artificial SEI onto $\mathrm{Fe}_{3} \mathrm{O}_{4}$ nanoparticles. The electrochemical tests of the $\mathrm{rGO} / \mathrm{Fe}_{3} \mathrm{O}_{4} @ \mathrm{PDA} \| \mathrm{Li}$ half-cell showed high specific capacity of $1358 \mathrm{mAh} \mathrm{g}^{-1}$ after 300 cycles at $1 \mathrm{~A} \mathrm{~g}^{-1}$ current rate, satisfying rate capability ( $\sim 600 \mathrm{mAh} \mathrm{g}^{-1}$ at 3C), and fast charge/discharge rate $\left(712 \mathrm{mAh} \mathrm{g}^{-1}\right.$ after 2000 cycles at $3 \mathrm{~A} \mathrm{~g}^{-1}$ ). Rice crust-like structure of thin carbon layer $\left(\sim 2 \mathrm{~nm}\right.$ thick) coated $\mathrm{Fe}_{3} \mathrm{O}_{4}$ nanoparticles $(\sim 15 \mathrm{~nm})$ uniformly covering rGO sheets was obtained via solvothermal process with subsequent annealing at $600{ }^{\circ} \mathrm{C}$ for $1 \mathrm{~h}$ under flowing Ar gas (100 sccm) [393]. This $\mathrm{Fe}_{3} \mathrm{O}_{4} @ \mathrm{C} / \mathrm{rGO}$ composite showed a specific capacity of $\sim 970 \mathrm{mAh} \mathrm{g}^{-1}$ at $0.2 \mathrm{~A} \mathrm{~g}^{-1}$. At higher current rate $\left(5 \mathrm{~A} \mathrm{~g}^{-1}\right)$, it exhibited a capacity of $420 \mathrm{mAh} \mathrm{g}^{-1}$, which is much higher than that of the composite $\mathrm{Fe}_{3} \mathrm{O}_{4} / \mathrm{rGO}$ without carbon coating. The $\mathrm{Fe}_{3} \mathrm{O}_{4} @ \mathrm{C} / \mathrm{rGO}$ anode cycled 1000 times at $5 \mathrm{~A} \mathrm{~g}^{-1}$ delivered $594 \mathrm{mAh} \mathrm{g}^{-1}$ with a $\mathrm{CE}$ of $99.4 \%$. The authors stated that 
the charge/discharge process occurs with two reactions: A conversion reaction (above $0.8 \mathrm{~V}$ ) and a surface adsorption (below $0.8 \mathrm{~V}$ ), which is attributed to the pseudocapacitance contribution calculated at $89 \%$, originating from the carbon coated nanostructure. A ternary $\mathrm{Fe}_{3} \mathrm{O}_{4}-\mathrm{MoO}_{3} / \mathrm{rGO}$ nano-composite prepared by microwave hydrothermal method was deposited on carbon cloth (CC) [394]. The detailed morphological studies showed that $\mathrm{Fe}_{3} \mathrm{O}_{4}-\mathrm{MoO}_{3}$ nanoparticles were decorated on thin sheets of $\mathrm{rGO}$ with a resolution of $50 \mathrm{~nm}$. The as-prepared $\mathrm{Fe}_{3} \mathrm{O}_{4}-\mathrm{MoO}_{3} / \mathrm{rGO}-@ \mathrm{CC}$ electrode showed a specific capacitance of $1666 \mathrm{~F} \mathrm{~g}^{-1}$ at a current density of $2.5 \mathrm{~A} \mathrm{~g}^{-1}$ and a capacitance retention of $95 \%$ after 5000 cycles. A NiO/ $/ \mathrm{Fe}_{3} \mathrm{O}_{4} / \mathrm{rGO}$ composite obtained via a solvothermal route consisted of $\mathrm{Fe}_{3} \mathrm{O}_{4}$ nanospheres (average size $\sim 150 \mathrm{~nm}$ ) and rod-shaped $\mathrm{NiO}$ particles (about $300 \mathrm{~nm}$ ) distributed on the surface of $\mathrm{rGO}$. The porous $\mathrm{NiO} / \mathrm{Fe}_{3} \mathrm{O}_{4} / \mathrm{rGO}$ sample exhibits a BET specific surface and average pore diameter of $497 \mathrm{~m}^{2} \mathrm{~g}^{-1}$ and $1.2 \mathrm{~nm}$, respectively. The initial discharge capacity was $841 \mathrm{mAh} \mathrm{g}^{-1}$ and maintained $647 \mathrm{mAh} \mathrm{g}^{-1}$ after 200 cycles at the current density of $0.5 \mathrm{Ag}^{-1}$. Rate capability tests showed that the discharge capacity was still $582 \mathrm{mAh} \mathrm{g}^{-1}$ after 200 cycles at $1 \mathrm{~A} \mathrm{~g}^{-1}$ [395].

Recently, Xiao et al. [396] reported the fabrication of multi-layered graphene oxide$\mathrm{Fe}_{3} \mathrm{O}_{4} @$ polydopamine-polyacrylamide (rGO-Fe $\left.\mathrm{O}_{4} @ P D A-P A M\right)$ composites through a green and scalable strategy. In this assembly, $\mathrm{Fe}_{3} \mathrm{O}_{4}$ nanoparticles (NPs) were confined by the PDA shell and rGO sheets. Gao et al. [397] developed a simple one-step hydrothermal method to prepare $\mathrm{Fe}_{3} \mathrm{O}_{4} / \mathrm{FeS} / \mathrm{rGO}$ composite with a uniform deposition of octahedral $\mathrm{Fe}_{3} \mathrm{O}_{4} / \mathrm{FeS}$ particles on the rGO. This structural design delivered a reversible capacity of $744 \mathrm{mAh} \mathrm{g}^{-1}$ at $0.1 \mathrm{C}$ rate after 50 cycles showing excellent interface stability. Using broccoli-like multichannel $\mathrm{FeCO}_{3}$ microspheres as raw material, the $\mathrm{Fe}_{3} \mathrm{O}_{4}$ nanoflakes/rGO composites were realized via a low temperature hydrolysis reaction in the presence of graphene and hydrazine. The $\mathrm{Fe}_{3} \mathrm{O}_{4} \mathrm{NFs} / \mathrm{rGO}$ electrode exhibited a satisfied capacity of $925.3 \mathrm{mAh} \mathrm{g}^{-1}$ with $68.8 \%$ retention and retained a capacity of $636.1 \mathrm{mAh} \mathrm{g}^{-1}$ after 1000 cycles at $0.5 \mathrm{~A} \mathrm{~g}^{-1}$ [380].

$\mathrm{Fe}_{3} \mathrm{O}_{4}$ was intercalated into rGO and conductive carbon layers to form a 3D sandwich-like $\mathrm{C} / \mathrm{Fe}_{3} \mathrm{O}_{4} / \mathrm{rGO}$ architecture. The composite, prepared by one-pot solvothermal process, exhibited excellent electrochemical performance as anode in LIB with specific capacity of $844 \mathrm{mAh} \mathrm{g}^{-1}$ at $0.2 \mathrm{~A} \mathrm{~g}^{-1}$ after 300 cycles and high-rate cyclic performance (i.e., $363 \mathrm{mAh} \mathrm{g}^{-1}$ at $4 \mathrm{~A} \mathrm{~g}^{-1}$ after 300 cycles. Meanwhile, when used as ESC electrode, the $\mathrm{C} / \mathrm{Fe}_{3} \mathrm{O}_{4} / \mathrm{rGO}$ hybrid showed a pseudocapacitance of $77 \%$ when scan rate is $5 \mathrm{mV} \mathrm{s}^{-1}$ [398]. Liang and Lu developed a new technique for the fabrication of $\mathrm{Fe}_{3} \mathrm{O}_{4} / \mathrm{rGO}$ nanocomposites, namely the gamma-irradiation method, in which the iron(III) hydroxide and $\mathrm{GO}$ are reduced to $\mathrm{Fe}_{3} \mathrm{O}_{4}$ and $\mathrm{rGO}$ by the reducing species generated from the radiolysis of the solvent [399]. The electrochemical performances of the $\mathrm{Fe}_{3} \mathrm{O}_{4} / \mathrm{rGO}$ composite containing various amounts of $\mathrm{Fe}_{3} \mathrm{O}_{4}$ evaluated in coin-type cells yielded good cycling stability at a low current density of $50 \mathrm{~mA} \mathrm{~g}^{-1}$. The specific discharge capacity of with $78.8 \mathrm{wt} \% \mathrm{Fe}_{3} \mathrm{O}_{4} / \mathrm{rGO}$ remained at $568.6 \mathrm{mAh} \mathrm{g}^{-1}$ after 100 cycles, while the $74.7 \mathrm{wt} \% \mathrm{Fe}_{3} \mathrm{O}_{4} / \mathrm{rGO}$ electrode exhibited a sustained discharge capacity is $738.5 \mathrm{mAh} \mathrm{g}^{-1}$ after 100 cycles at current density of $500 \mathrm{~mA} \mathrm{~g}^{-1}$. Copper-ferrite-based composites, namely $\mathrm{CuFeO}_{2} / \mathrm{rGO}$ and $\mathrm{Cu} / \mathrm{CuFeO}_{2} / \mathrm{rGO}$ were proposed by Wang et al. [400] as high-performance anode materials for LIBs. A four-step synthesis consisted in: (i) The formation of the $\mathrm{CuFeO}_{2}$ delafossite crystals in an alcoholic solution containing $\mathrm{Fe}\left(\mathrm{NO}_{3}\right)_{3}$ and $\mathrm{Cu}\left(\mathrm{NO}_{3}\right)_{2}$ dissolved species, and (ii) the mixture of the GO suspension and the $\mathrm{CuFeO}_{2}$-like solution with control of the $\mathrm{pH}$ at 12 by $6 \mathrm{~mol} \mathrm{~L}^{-1}$ $\mathrm{NaOH}$, (iii) an hydrothermal process at $180^{\circ} \mathrm{C}$ for $12 \mathrm{~h}$, and finally (iv) a calcination in a tube furnace at $400{ }^{\circ} \mathrm{C}$ for $2 \mathrm{~h}$ under a $\mathrm{N}_{2}$ atmosphere. The TEM images of the as-prepared hybrids revealed that ultrafine nanoparticles (15-25 $\mathrm{nm}$ in diameter) decorated the graphene nanosheets. When tested in the voltage range $0.02-3.0 \mathrm{~V}$ vs. $\mathrm{Li}^{+/} \mathrm{Li}_{\text {at }} 200 \mathrm{~mA} \mathrm{~g}^{-1}$ current rate, the sheet-on-sheet $\mathrm{CuFeO}_{2} / \mathrm{rGO}$ electrode displayed a reversible capacity of $587 \mathrm{mAh} \mathrm{g}^{-1}$ after 100 cycles, while the $\mathrm{Cu} / \mathrm{CuFe}_{2} \mathrm{O}_{4} @ \mathrm{rGO}$ hybrid, containing combined nano-copper and $\mathrm{rGO}$, manifested a superior rate capability of 723 and $560 \mathrm{mAh} \mathrm{g}^{-1}$ at 0.8 and $3.2 \mathrm{~A} \mathrm{~g}^{-1}$, respectively and a cyclability of $1102 \mathrm{mAh} \mathrm{g}^{-1}$ after 250 cycles at $800 \mathrm{~mA} \mathrm{~g}^{-1}$ rate. Table 7 summarizes the electrochemical performances of iron oxide/rGO composites. 
Table 7. Summary of electrochemical performances of iron oxide/rGO composites. Relevant cycle number is displayed in brackets.

\begin{tabular}{|c|c|c|c|c|}
\hline Material & Synthesis & $\begin{array}{l}\text { Specific Capacity } \\
\quad\left(m A h g^{-1}\right)\end{array}$ & $\begin{array}{l}\text { Current Density } \\
\quad\left(\mathrm{A} \mathrm{g}^{-1}\right)\end{array}$ & Ref. \\
\hline $\mathrm{Fe}_{3} \mathrm{O}_{4} / \mathrm{rGO}$ & co-precipitation + annealing & 200 & 9.26 & [383] \\
\hline $\mathrm{Fe}_{3} \mathrm{O}_{4} / \mathrm{rGO}$ & microwave-assisted combustion & 446 & $5 C(50)$ & [389] \\
\hline $\mathrm{Fe}_{3} \mathrm{O}_{4} / \mathrm{rGO}$ & coprecipitation & 300 & $1.0(100)$ & [390] \\
\hline $\mathrm{Fe}_{3} \mathrm{O}_{4} / \mathrm{rGO}$ & hydrothermal + heating & 593 & $5.0(400)$ & [378] \\
\hline $\mathrm{Fe}_{3} \mathrm{O}_{4} / \mathrm{rGO}$ & redox reaction & 584 & $5.0(450)$ & [388] \\
\hline $\mathrm{Fe}_{3} \mathrm{O}_{4} / \mathrm{CNTs} / \mathrm{rGO}$ & electrophoretic deposition & 1080 & $1.0(450)$ & [387] \\
\hline $\mathrm{rGO} / \mathrm{Fe}_{3} \mathrm{O}_{4} @ \mathrm{PDA}$ & $\begin{array}{l}\text { hydrothermal + calcination } \\
\text { solvothermal }\end{array}$ & 712 & $3.0(2000)$ & [392] \\
\hline $\mathrm{Fe}_{3} \mathrm{O}_{4} @ \mathrm{C} / \mathrm{rGO}$ & hydrothermal + calcination & 594 & $5.0(1000)$ & [393] \\
\hline $\mathrm{Fe}_{3} \mathrm{O}_{4} / \mathrm{FeS} / \mathrm{rGO}$ & hydrolysis & 744 & $1 C(50)$ & [397] \\
\hline $\mathrm{Fe}_{3} \mathrm{O}_{4} \mathrm{NFs} / \mathrm{rGO}$ & gamma-irradiation method & 636 & $0.5(1000)$ & [380] \\
\hline $\begin{array}{l}78.8 \\
\mathrm{wt} \% \mathrm{Fe}_{3} \mathrm{O}_{4} / \mathrm{rGO}\end{array}$ & gamma-irradiation method & 568 & $0.05(100)$ & [399] \\
\hline $\begin{array}{l}74.7 \\
\mathrm{wt} \% \mathrm{Fe}_{3} \mathrm{O}_{4} / \mathrm{rGO}\end{array}$ & solvothermal & 738 & $0.5(100)$ & [399] \\
\hline $\mathrm{NiO} / \mathrm{Fe}_{3} \mathrm{O}_{4} / \mathrm{rGO}$ & electrostatic assembly & 580 & $1.0(200)$ & [395] \\
\hline $\mathrm{CP} / \mathrm{Fe}_{3} \mathrm{O}_{4} / \mathrm{rGO}$ & solvothermal & 1160 & $0.5(1000)$ & [401] \\
\hline $\mathrm{Fe}_{3} \mathrm{O}_{4} / \mathrm{rGO}$ & PMAA-induced self-assembly & 992 & $0.15(100)$ & [402] \\
\hline $\mathrm{Fe}_{3} \mathrm{O}_{4} / \mathrm{rGO}$ & hydrothermal + calcination & 740 & $0.5(200)$ & [391] \\
\hline $\mathrm{CuFeO}_{2} / \mathrm{rGO}$ & one-pot solvothermal & 587 & $0.2(100)$ & [400] \\
\hline $\mathrm{C} / \mathrm{Fe}_{3} \mathrm{O}_{4} / \mathrm{rGO}$ & & 844 & $0.2(300)$ & [398] \\
\hline
\end{tabular}

\subsection{2. $\mathrm{Fe}_{2} \mathrm{O}_{3}$-Based Composites}

$\mathrm{Fe}_{2} \mathrm{O}_{3}$ (a-phase) has the advantages of rich ores, low price, and high theoretical capacity of $1007 \mathrm{mAh} \mathrm{g}^{-1}$ according the lithiation process, that is the conversion reaction $\mathrm{Fe}_{2} \mathrm{O}_{3}+6 \mathrm{Li}^{+}+6 \mathrm{e}^{-}$ $\leftrightarrow 3 \mathrm{Li}_{2} \mathrm{O}+2 \mathrm{Fe}^{0}$. In the anodic polarization process, the broad anodic peak at around $1.55 \mathrm{~V}$ is related to the reverse de-conversion process of $\mathrm{Li}_{2} \mathrm{O}$ with metallic iron. Since 2011, a- $\mathrm{Fe}_{2} \mathrm{O}_{3} / \mathrm{rGO}$ hybrids were recognized as important electrode materials for energy storage devices [403-407]. For example, Wang and his collaborators were one of the first researchers who demonstrated the enhanced performances of a- $\mathrm{Fe}_{2} \mathrm{O}_{3} / \mathrm{rGO}$ nanocomposites as anode materials for LIBs, showing a high discharge capacity of $660 \mathrm{mAh} \mathrm{g}^{-1}$ during up to 100 cycles at the current density of $160 \mathrm{~mA} \mathrm{~g}^{-1}$ [408].

In 2015, Wang et al. [409] fabricated cells with 3D mesostructured $\mathrm{Ni}$ scaffolded $\mathrm{Fe}_{2} \mathrm{O}_{3}$ electrodes. The voltage hysteresis was $0.62 \mathrm{~V}$ at $100 \mathrm{~mA} \mathrm{~g}^{-1}$ and was further reduced to $0.42 \mathrm{~V}$ at elevated temperature $\left(45^{\circ} \mathrm{C}\right)$. Zhu et al. [384] prepared $\mathrm{Fe}_{2} \mathrm{O}_{3} / \mathrm{rGO}$ composite using a co-precipitation/microwave technique. The as-prepared electrode exhibited a specific capacity of $1355 \mathrm{mAh} \mathrm{g}^{-1}$ after 50 cycles at $100 \mathrm{~mA} \mathrm{~g}^{-1}$. Liu et al. [410] built a nanocomposite of a- $\mathrm{Fe}_{2} \mathrm{O}_{3}$ nanoplates imbedded in graphene networks using a one-step hydrothermal method with water and glycerin as hydrothermal solvents. In this hybrid, the a- $\mathrm{Fe}_{2} \mathrm{O}_{3}$ nanoplates, with a size of $20-30 \mathrm{~nm}$, were well wrapped and closely connected by the flexible conductive network. The a- $\mathrm{Fe}_{2} \mathrm{O}_{3} / \mathrm{rGO}$ composite anode demonstrated high discharge capacities of $\sim 896 \mathrm{mAh} \mathrm{g}^{-1}$ up to 200 cycles at 5C rate and $\sim 429 \mathrm{mAh} \mathrm{g}^{-1}$ up to 1000 cycles even at a $10 \mathrm{C}$ rate. Lee et al. [411] prepared a- $\mathrm{Fe}_{2} \mathrm{O}_{3}$ hollow nanobarrels (a-HNBs, $\sim 200 \mathrm{~nm}$ in diameter, $\sim 360 \mathrm{~nm}$ in length) deposited on rGO using a one-step microwave-assisted hydrothermal process. The as-synthesized a-HNBs/rGO composite yielded superior electrochemical properties such as a reversible capacity of $1279 \mathrm{mAh} \mathrm{g}^{-1}$ at $0.5 \mathrm{C}$ rate after the first cycle, a long-term cycle ability of $478 \mathrm{mAh} \mathrm{g}^{-1}$ after 1000 cycles, and a high rate capability of $403 \mathrm{mAh} \mathrm{g}^{-1}$ even at $10 \mathrm{C}$ rate. The $\mathrm{g}-\mathrm{Fe}_{2} \mathrm{O}_{3} / \mathrm{RGO}$ composite electrode materials was prepared by the reduction of few layer $\mathrm{GO}$ to rGO by iron metal in aqueous solution under ambient conditions; the final product was obtained by calcination at $600{ }^{\circ} \mathrm{C}$ for $2 \mathrm{~h}$ under $\mathrm{N}_{2}$ atmosphere [412]. The g- $\mathrm{Fe}_{2} \mathrm{O}_{3}$ nanoparticles formed by the oxidation of iron were uniformly dispersed on the surface of rGO sheets. The g- $\mathrm{Fe}_{2} \mathrm{O}_{3} / \mathrm{RGO}$ composite anode, tested in the voltage range $0.01-3.0 \mathrm{~V}$ at $500 \mathrm{~mA} \mathrm{~g}^{-1}$ current rate, delivered an initial specific 
capacity of $850 \mathrm{mAh} \mathrm{g}^{-1}$, maintained at of $\sim 800 \mathrm{mAh} \mathrm{g}^{-1}$ after 300 cycles. When cycled at $15 \mathrm{~A} \mathrm{~g}^{-1}$ performance, the capacity remains stable at $200 \mathrm{mAh} \mathrm{g}^{-1}$.

Recently, Liu and coworkers [413] focused on the development of facile and low-cost synthetic method to grow $\mathrm{Fe}_{2} \mathrm{O}_{3} / \mathrm{rGO}$ hybrids. They used $\mathrm{FeCl}_{3}$ as the raw material and adopted different one-step hydrothermal methods (i.e., hydrothermal in-situ method, PVP-assisted hydrothermal in-situ method, or oleic acid-assisted hydrothermal in-situ method). A comparison of the electrochemical performance of the $\mathrm{Fe}_{2} \mathrm{O}_{3} / \mathrm{rGO}$ anodes prepared by these three processes shows that the oleic acid-assisted hydrothermal method is best. With this process, the initial specific discharge capacity was $1431 \mathrm{mAh} \cdot \mathrm{g}^{-1}$ at a current density of $100 \mathrm{~mA} \cdot \mathrm{g}^{-1}$, and, remained at $478 \mathrm{mAh} \cdot \mathrm{g}^{-1}$ after 50 cycles. Within similar conditions, capacities of 435 and $225 \mathrm{mAh} \cdot \mathrm{g}^{-1}$ were delivered by the anodes prepared by hydrothermal in-situ and PVP-assisted hydrothermal in-situ method, respectively.

\subsubsection{FeO-Based Composites}

Exfoliated graphene oxide (EGO)/iron (II) oxide $(\mathrm{FeO})$ composite was prepared by graphenothermal reduction process at $650{ }^{\circ} \mathrm{C}$ for $5 \mathrm{~h}$ in argon [414]. This composite displayed a measured BET of $11 \mathrm{~m}^{2} \mathrm{~g}^{-1}$, pore diameter of $10.6 \mathrm{~nm}$ and average pore volume of $\sim 0.064 \mathrm{~cm}^{3} \mathrm{~g}^{-1}$. Electrochemical tests showed a reversible capacity of $857 \mathrm{mAh} \mathrm{g}^{-1}$ at a current rate of $50 \mathrm{~mA} \mathrm{~g}^{-1}$ in the voltage range $0.005-3.0 \mathrm{~V} \mathrm{vs}$. $\mathrm{Li}^{+} / \mathrm{Li}$ with a high coulombic efficiency of $98 \%$ up to 60 cycles. As a cathode material for LIBs, $\mathrm{LiFePO}_{4} /$ graphene oxide (LFP/GO) composite was prepared by spray-drying and annealing processes, in which nanoparticles were wrapped homogeneously and loosely with the graphene 3D network facilitating electron migration throughout the secondary particles and fast $\mathrm{Li}^{+}$diffusion in the voids. The LFP/GO composite could deliver a specific capacity of $70 \mathrm{mAh} \mathrm{g}^{-1}$ at $60 \mathrm{C}$ discharge rate. After 1000 cycles, the capacity decay rate of $<15 \%$ was measured under $10 \mathrm{C}$ charging and $20 \mathrm{C}$ discharging [415]. One type of Li-ion storage material with fast faradaic surface redox reaction offers high power density but limited in some extent of energy contribution. Qi et al. demonstrated that in-situ pulverized $\mathrm{FeOOH}$ rods on rGO sheets exhibit a pseudocapacitance storage behavior $(82 \%$ of the total capacity). The FeOOH/rGO composite achieved specific capacities of 1135 and $783 \mathrm{mAh} \mathrm{g}^{-1}$ at current rate of 1.0 and $5.0 \mathrm{~A} \mathrm{~g}^{-1}$, respectively, over 200 cycles [416].

\subsection{Vanadium-Based Oxide Composites}

Vanadium oxides $\left(\mathrm{VO}_{\mathrm{x}}\right)$ exist in various compositions (e.g., $\mathrm{V}_{2} \mathrm{O}_{5}, \mathrm{~V}_{3} \mathrm{O}_{7}, \mathrm{~V}_{4} \mathrm{O}_{9}, \mathrm{~V}_{6} \mathrm{O}_{13}, \mathrm{VO}_{2}, \mathrm{~V}_{2} \mathrm{O}_{3}$, etc.), depending on the oxidation state $\left(5^{+}\right.$to $\left.2^{+}\right)$of vanadium. They have attracted considerable attention as potential electrode materials for energy storage devices (LIBs, SIBs, ESCs) [417].

\subsection{1. $\mathrm{VO}_{2}$-Based Composites}

Since the 1980s, vanadium oxides $\mathrm{VO}_{2+\mathrm{y}}(0 \leq y \leq 0.5)$ are known for lithium storage applications [418]. $\mathrm{VO}_{2}(\mathrm{R})$ is the most stable phase, which crystallizes in the rutile-like structure (monoclinic, $\mathrm{C} 2 / m$ space group). Nanocrystalline $\mathrm{VO}_{2}(\mathrm{~B})$ is a metastable, which crystallizes in the monoclinic structure with a fibrous morphology owing to its $\mathrm{V}_{4} \mathrm{O}_{10}$-type double layers to form $\mathrm{V}$-O tunnels perpendicular to the $c$-axis for rapid lithium-ion insertion/deinsertion process. Typically, $\mathrm{VO}_{2} / \mathrm{rGO}$ composites are synthesized by either freeze-drying or a solvothermal method. In the freeze-drying, a dispersed suspension is obtained by mixing graphene oxide and ammonium vanadate in water and freeze in liquid nitrogen; finally, the $\mathrm{VO}_{2} / \mathrm{rGO}$ composite is grown after calcination at $500{ }^{\circ} \mathrm{C}$ for $5 \mathrm{~h}$ under Ar conditions. During this process, $\mathrm{NH}_{4} \mathrm{VO}_{3}$ is converted into $\mathrm{VO}_{2}\left(\mathrm{NH}_{4} \mathrm{VO}_{3}+\mathrm{C}\right.$ $\rightarrow \mathrm{NH}_{3}+\mathrm{VO}_{2}+\mathrm{CO}_{2}+\mathrm{H}_{2} \mathrm{O}$ ) with simultaneous reduction of $\mathrm{GO}$ to $\mathrm{rGO}$ [419]. In the solvothermal method, the $\mathrm{VOC}_{2} \mathrm{O}_{4}$ clear dark blue solution formed by the mixture vanadium pentoxide and oxalic acid (molar ratio 1:3) in water is added to a GO dispersion and hydrothermally treated in butanol at $200{ }^{\circ} \mathrm{C}$ for $8 \mathrm{~h}$. Finally, the $\mathrm{VO}_{2} / \mathrm{rGO}$ composite is obtained after alcohol washing at $80{ }^{\circ} \mathrm{C}$ for $8 \mathrm{~h}$ [420]. In a two-step hydrothermal reaction, well-dispersed $\mathrm{VO}_{2}(\mathrm{~B})$ nanorods with diameter of $40 \mathrm{~nm}$ and length of $150 \mathrm{~nm}$ are grown using $\mathrm{V}_{2} \mathrm{O}_{5}$ as raw material and rod-like vanadyl ethylene 
glycolate as intermediate product, separately. The $3 \mathrm{D} \mathrm{VO}_{2}(\mathrm{~B}) / \mathrm{rGO}$ composite is obtained by adding $\mathrm{GO}$. Electrochemical test shows that the close connection between $\mathrm{rGO}$ sheets and $\mathrm{VO}_{2}(\mathrm{~B})$ NRs improved the cycling stability [421].

$\mathrm{VO}_{2}(\mathrm{~B}) / \mathrm{rGO}$ nanocomposite was synthesized via a one-step microwave-assisted solvothermal process from $\mathrm{VOC}_{2} \mathrm{O}_{4}$ obtained by dissolution of $\mathrm{V}_{2} \mathrm{O}_{5}$ in the presence of oxalic acid [422]. The $\mathrm{VO}_{2}(\mathrm{~B}) / \mathrm{rGO}$ hybrid reveals good performance as an anode in lithium-ion batteries with an initial capacity of $400 \mathrm{mAh} \mathrm{g}^{-1}$ and a reversible specific capacity of $200 \mathrm{mAh} \mathrm{g}^{-1}$ over 400 cycles in the potential range 3.0-0.05 V vs. $\mathrm{Li}^{+} / \mathrm{Li}$. Nethravathi et al. [423] performed a hydrothermal reaction of a mixture of a colloidal dispersion of $\mathrm{GO}$ and $\mathrm{NH}_{4} \mathrm{VO}_{3}$, which yielded a $\mathrm{VO}_{2}(\mathrm{~B}) / \mathrm{GO}$ hybrid. The nanotubular morphology of $\mathrm{VO}_{2}(\mathrm{~B})$ wrapped between graphene sheets improved the charge transfer and achieved $\sim 450 \mathrm{mAh} \mathrm{g}^{-1}$ at $40 \mathrm{~mA} \mathrm{~g}^{-1}$ current rate. Song et al. [424] investigated an rGO supported $\mathrm{VO}_{2}(\mathrm{M})$ nanocomposite prepared via a one-step sol-gel assisted hydrothermal process. A GO-dispersed $\mathrm{V}_{2} \mathrm{O}_{5}$ gel was reduced with an appropriate hydrazine monohydrate $\left(\mathrm{N}_{2} \mathrm{H}_{4} \cdot \mathrm{H}_{2} \mathrm{O}\right)$ as strong reductant and hydrothermally treated at $220^{\circ} \mathrm{C}$ for $24 \mathrm{~h}$. From this synthesis, the as-prepared M-phase $\mathrm{VO}_{2}$ nanoparticles (20 $50 \mathrm{~nm}$ in size) well dispersed in $\mathrm{rGO}$ exhibits the monoclinic $\left(P 2_{1} / \mathrm{c}\right.$ space group) structure. The discharge capacity of $\mathrm{VO}_{2}(\mathrm{M}) / \mathrm{rGO}$ electrode is $283 \mathrm{mAh} \mathrm{g}^{-1}$ at a current density of $60 \mathrm{~mA} \mathrm{~g}^{-1}$ over 200 cycles. The rate capability showed a capacity of $210 \mathrm{mAh} \mathrm{g}^{-1}$ at $300 \mathrm{~mA} \mathrm{~g}^{-1}$. Choi et al. [425] prepared $\mathrm{VO}_{2}$-decorated rGO balls using a one-pot spray-pyrolysis process from a colloidal spray solution of well-dispersed $\mathrm{GO}$ and $\mathrm{NH}_{4} \mathrm{VO}_{3}$ followed by post-treatment at $300^{\circ} \mathrm{C}$ in an air atmosphere. The as-prepared $\mathrm{VO}_{2}$ (B) nanorods ( $200 \mathrm{~nm}$ in diameter) are encapsulated by rGO nanosheets. The $\mathrm{rGO} / \mathrm{VO}_{2}$ composite with $5 \mathrm{wt} \%$ graphene showed an initial discharge and charge capacities of 148 and $135 \mathrm{mAh} \mathrm{g}^{-1}$, respectively, at $300 \mathrm{~mA} \mathrm{~g}^{-1}$ current rate. A free-standing $\mathrm{VO}_{2.07} / \mathrm{rGO}$ film was fabricated through hydrothermal process using $\mathrm{NH}_{4} \mathrm{VO}_{3}$. and GO in $1 \mathrm{~mol} \mathrm{~L}^{-1}$ $\mathrm{HNO}_{3}$ aqueous solution [426]. The as-prepared nanoribbons ( $30 \mathrm{~nm}$ thick, $50 \mu \mathrm{m}$ long) were annealed at $300{ }^{\circ} \mathrm{C}$ in $\mathrm{N}_{2}$ atmosphere and tested as cathode material (mass loading of $1.2 \mathrm{mg} \mathrm{cm}^{-2}$ ) in Li cell. The $\mathrm{VO}_{2.07} / \mathrm{rGO}$ intertwining network exhibits a reversible specific capacity of $160 \mathrm{mAh} \mathrm{g}^{-1}$ and good cycling stability of $133 \mathrm{mAh} \mathrm{g}^{-1}$ after 200 cycles at a current density of $70 \mathrm{~mA} \mathrm{~g}^{-1}$ in the voltage range between 2.0 and $3.5 \mathrm{~V}$.

Xiao et al. [427] prepared $\mathrm{VO}_{2} / \mathrm{rGO}$ composites by a simple one-step hydrothermal method. Samples consist of $\mathrm{VO}_{2}$ flakes anchored with rGO. When used as anode for Li-ion battery, this $\mathrm{VO}_{2} / \mathrm{rGO}$ composite yields a high capacity of $\sim 622 \mathrm{mAh} \mathrm{g}^{-1}$ at $100 \mathrm{~mA} \mathrm{~g}^{-1}$ and maintains a capacity of $256 \mathrm{mAh} \mathrm{g}^{-1}$ after 300 cycles at $2 \mathrm{~A} \mathrm{~g}^{-1}$ with capacity retention of almost $100 \%$. Yan et al. [420] encapsuled $\mathrm{VO}_{2}$ nanospheres (average diameter of $\sim 500 \mathrm{~nm}$ ) into crumpled rGO using a one-step rapid and scalable solvothermal approach at $200^{\circ} \mathrm{C}$ for $8 \mathrm{~h}$. The as-prepared sample has a BET specific surface area of $130.4 \mathrm{~m}^{2} \mathrm{~g}^{-1}$. The sodiation reaction of $\mathrm{VO}_{2} / \mathrm{rGO}$ composites tested in the voltage range of 3.0 to $0.01 \mathrm{~V}$ vs. $\mathrm{Na}^{+} / \mathrm{Na}$ results in a reversible capacity of $383 \mathrm{mAh} \mathrm{g}^{-1}$ at $0.1 \mathrm{~A} \mathrm{~g}^{-1}$ and $214 \mathrm{mAh} \mathrm{g}^{-1}$ at $4 \mathrm{~A} \mathrm{~g}^{-1}$, and long-term stability over 2000 cycles at $4 \mathrm{~A} \mathrm{~g}^{-1}$ with a capacity fade of $0.013 \%$ per cycle. Dai et al. [419] demonstrated a highly reversible zinc/vanadium dioxide system, where freestanding reduced graphene oxide/vanadium dioxide $\left(\mathrm{rGO} / \mathrm{VO}_{2}\right)$ composite films were used as the cathodes of $\mathrm{Zn}$-ion batteries. When cycled at $4 \mathrm{~A} \mathrm{~g}^{-1}$, the $\mathrm{rGO} / \mathrm{VO}_{2}$ hybrid exhibit an excellent discharge capacity of $240 \mathrm{mAh} \mathrm{g}^{-1}$ with a coulombic efficiency $\sim 100 \%$ and $\sim 100 \%$ capability retention over 1000 cycles.

Graphene woven $\mathrm{VO}_{2}$ nanoribbons synthesized using in-situ hydrothermal method show high discharge capacity ( $\left.380 \mathrm{mAh} \mathrm{g}^{-1}\right)$ and $99 \%$ capacity retention after 50 cycles [428]. Dai et al. [419] investigated the electrochemical performance of $\mathrm{VO}_{2} / \mathrm{rGO}$ films in Zin-ion batteries. The composites synthesized by freeze-drying method delivers a specific capacity of $276 \mathrm{mAh} \mathrm{g}^{-1}$ at a current rate of $0.1 \mathrm{~A} \mathrm{~g}^{-1}$ in the potential range of $0.3-1.3 \mathrm{~V}$ (energy density of $65 \mathrm{Wh} \mathrm{kg}^{-1}$ ) and exhibits excellent capacity retention of $99 \%$ after 1000 cycles. A considerable capacity of $120 \mathrm{mAh} \mathrm{g}^{-1}$ was still obtained at high rate of $35 \mathrm{~A} \mathrm{~g}^{-1}$. Recently, Cui et al. [429] designed a cathode material for $\mathrm{Zn}$-ion batteries consisting in $\mathrm{VO}_{2}(\mathrm{~B})$ nanobelts uniformly deposited on to rGO nanoflakes via a one-step hydrothermal route. The $\mathrm{VO}_{2}(\mathrm{~B}) / \mathrm{rGO}$ composite presents a specific capacity of $456 \mathrm{mAh} \mathrm{g}^{-1}$ at $0.1 \mathrm{~A} \mathrm{~g}^{-1}$. Cycling 
performance shows an excellent capacity retention of $72 \%$ after 1600 cycles at $5 \mathrm{~A} \mathrm{~g}^{-1}$. Zhao et al. [430] investigated $\mathrm{VO}_{\mathrm{x}} / \mathrm{rGO}$ composites as cathode materials for Li-ion batteries using a facile hydrothermal method at $190{ }^{\circ} \mathrm{C}$ for $48 \mathrm{~h}$. Black precursor heat treated at $500{ }^{\circ} \mathrm{C}$ for $2 \mathrm{~h}$ produced a $\mathrm{V}_{2} \mathrm{O}_{5} / \mathrm{rGO}$ composite (BET surface area of $64 \mathrm{~m}^{2} \mathrm{~g}^{-1}$ ), while treat at $550{ }^{\circ} \mathrm{C}$ for $2 \mathrm{~h}$ in $\mathrm{N}_{2}$ atmosphere resulted in a $\mathrm{VO}_{2} / \mathrm{rGO}$ hybrid material (BET surface area of $35 \mathrm{~m}^{2} \mathrm{~g}^{-1}$ ) with the $\mathrm{VO}_{2}(\mathrm{R})$ phase. The obtained $\mathrm{VO}_{2}$ had a uniform lamellar 3D structure with thickness of $20 \mathrm{~nm}$. The $\mathrm{VO}_{2} / \mathrm{rGO}$ cathode exhibited an initial specific capacity of $115 \mathrm{mAh} \mathrm{g}^{-1}$ with a retention of $74 \%$ after 100 cycles.

$\mathrm{VO}_{2}(\mathrm{~B}) / \mathrm{rGO}$ composite formed by the assembly of $\mathrm{VO}_{2}(\mathrm{~B})$ nanoparticles and $\mathrm{rGO}$ were also used as electrodes for ESCs [431-437]. $\mathrm{VO}_{2}$ (B) nanobelts/rGO composite films were fabricated as electrodes for high-performance flexible all-solid-state supercapacitors [421]. The assembly composed of nanobelts with length of 3-5 $\mu \mathrm{m}$ and width of 40-150 nm, provide the maximum power density of $7152 \mathrm{~W} \mathrm{~kg}^{-1}$ at the energy density of $3.13 \mathrm{Wh} \mathrm{kg}^{-1}$. Lee et al. examined the effect of the ultra-large graphene transverse dimension $(47 \pm 22 \mu \mathrm{m})$ on the electrochemical properties of $\mathrm{VO}_{2}(\mathrm{~B}) / \mathrm{rGO}$ composites for ESC. The hybrid electrode with ultra-large rGO performs lower sheet resistance $\left(0.57 \mathrm{~kW} \mathrm{sq}^{-1}\right)$ than the composite with rGO of $0.8 \mu \mathrm{m}$ lateral size. Excellent capacitive performance of $769 \mathrm{~F} \mathrm{~g}^{-1}$ was reported [431]. A 2D nanocomposite was built by the uniform distribution of $3 \mathrm{D} \mathrm{VO}_{2}$ (B) flowers on $\mathrm{N}$-doped GO (N-GO) [436]. The anchoring of the $\mathrm{VO}_{2}(\mathrm{~B})$ flowers to $\mathrm{N}-\mathrm{GO}$ results in high surface area of $71 \mathrm{~m}^{2} \mathrm{~g}^{-1}$ and shows enhanced electrochemical performance, i.e., after 50 cycles, the hybrid retained $251 \mathrm{mAh} \mathrm{g}^{-1}$ (60\% retention). GO-coated $\mathrm{VO}_{2}(\mathrm{~B})$ nanomaterials were synthesized from a $\mathrm{VOSO}_{4}$ sol using a hydrothermal approach [437]. The functionalized GO-coated $\mathrm{VO}_{2}$ (B) exhibits an urchin-like spherical shape $(10-50 \mathrm{~nm})$. Investigated as cathode materials deposited on stainless-steel mesh within a voltage range $1.5-4.0 \mathrm{~V}$ vs. $\mathrm{Li} / \mathrm{Li}^{+}$at current density $100 \mathrm{~mA} \mathrm{~g}^{-1}$, these $\mathrm{GO}$-coated $\mathrm{VO}_{2}(\mathrm{~B})$ nanomaterials exhibit a discharge capacity of $240 \mathrm{mAh} \mathrm{g}^{-1}$. Cycling performance of $220 \mathrm{mAh} \mathrm{g}^{-1}$ was achieved after 20 cycles ( $10 \%$ capacity loss). Hierarchical $\mathrm{VO}_{2}(\mathrm{~B}) / \mathrm{rGO}$ composite, synthesized through the hydrothermal route at $180^{\circ} \mathrm{C}$ for $24 \mathrm{~h}$, was investigated as an anode and activated carbon on carbon cloth (CC) as a cathode in battery-supercapacitor hybrid (BSH) device taking advantage of the mixed valency of $\mathrm{V}\left(\mathrm{V}^{3+}\right.$ and $\left.\mathrm{V}^{4+}\right)$ inside the as-prepared $\mathrm{VO}_{2}$ matrix, which facilitates redox reaction in working potential of $0.01-3.0 \mathrm{~V} \mathrm{vs.} \mathrm{Li}^{+/} \mathrm{Li}$. The $\mathrm{VO}_{2}(\mathrm{~B}) / \mathrm{rGO}$ heterostructure yields a high specific capacity of $1214 \mathrm{mAh} \mathrm{g}^{-1}$ at current rate of $0.1 \mathrm{~A} \mathrm{~g}^{-1}$ after 120 cycles, with a high rate capability and stability [434]. The kinetic activation of the composite toward the electrochemical reaction during the activation period for Li-ion penetration resulting in the unconventional increase in the specific capacitance was observed with the increase in the number of cycles. Lv and coworkers [435] constructed a porous-type $\mathrm{VO}_{2}(\mathrm{~B}) / \mathrm{rGO}$ framework formed of flexible $\mathrm{rGO}$ sheets and $\mathrm{VO}_{2}(\mathrm{~B})$ nanobelts intertwined together, which exhibits a specific capacitance of $353 \mathrm{~F} \mathrm{~g}^{-1}$ at $1 \mathrm{~A} \mathrm{~g}^{-1}$ current rate. The increased transport of ions and electrons by the porous structures allows a capacitance retention of $78 \%$ after 10,000 cycles at $10 \mathrm{~A} \mathrm{~g}^{-1}$. Recently, Kang et al. [438] developed a mesoporous $\mathrm{VO}_{2}(\mathrm{~B}) / \mathrm{rGO}$ composite, which had facile access of $\mathrm{Li}$ ions to storage site. The composite electrode with a large specific surface area and pore volume of $335 \mathrm{~m}^{2} \mathrm{~g}^{-1}$ and $3.09 \mathrm{~cm}^{3} \mathrm{~g}^{-1}$, respectively, achieves a specific capacity of $226 \mathrm{mAh} \mathrm{g}^{-1}$ at $50 \mathrm{~mA} \mathrm{~g}^{-1}$ current density and superior capacity retention of $67.5 \%$ over 40 cycles at current density up to $2000 \mathrm{~mA} \mathrm{~g}^{-1}$ (Figure 13). Electrochemical performance of $\mathrm{VO}_{2} / \mathrm{rGO}$ composites as anodes or cathode for LIBs from the recent literature are summarized in Table 8. 
a
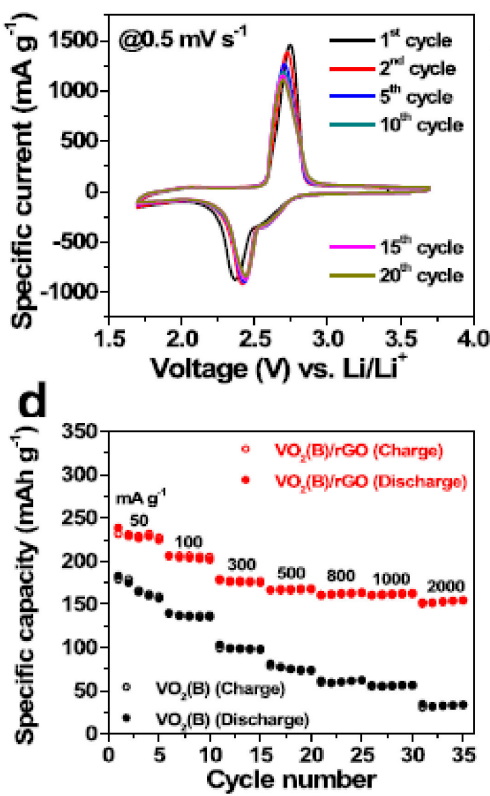

b

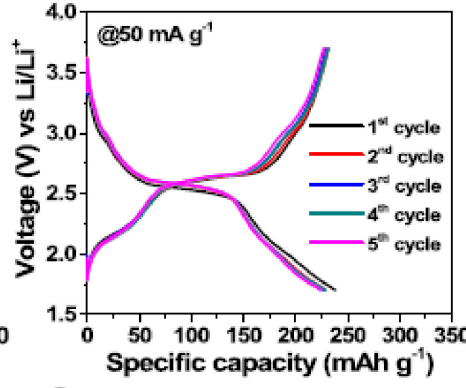

e
C
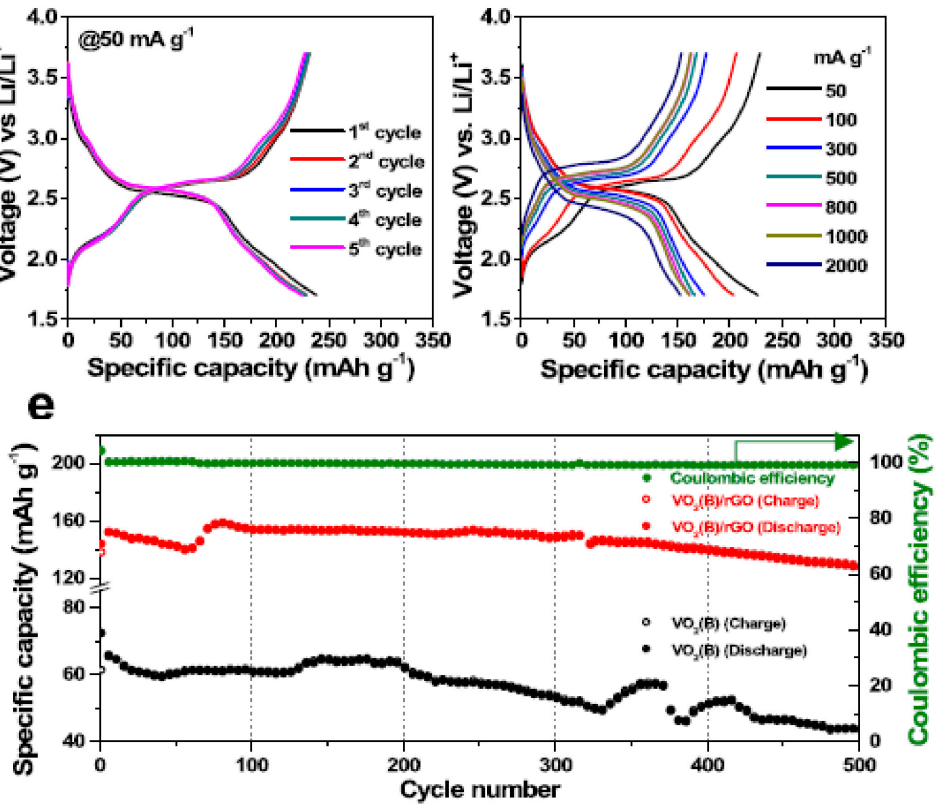

Figure 13. Electrochemical analysis of $\mathrm{VO}_{2}(\mathrm{~B}) / \mathrm{rGO}$ composite. (a) $\mathrm{CV}$ curves for 20th cycles. (b) GCD profiles at $50 \mathrm{~mA} \mathrm{~g}^{-1}$, (c) GCD profiles at various current densities from 50 to $2000 \mathrm{~mA} \mathrm{~g}^{-1}$. (d) Rate capability. (e) Cyclic stability test at $1000 \mathrm{~mA} \mathrm{~g}^{-1}$ of $\mathrm{VO}_{2}$ (B)/rGO composite compared with bare $\mathrm{VO}_{2}$ (B). Reproduced with permission from [438]. Copyright 2021 Elsevier.

Although the present work focuses on the graphene-based composite electrodes for Li-ion batteries, it should also be noted that $\mathrm{VO}_{2} / \mathrm{rGO}$ was also successful as a cathode for lithium sulfur batteries. The chemistry of such batteries is different, since the major difficulty is to solve the so-called shuttle effect of lithium polysulfides, but a $\mathrm{VO}_{2} / \mathrm{rGO}$ proved to be able to solve this problem. The polar $\mathrm{VO}_{2}$ can chemically anchor and catalyze the conversion of polysulfides and thus avoid their dissolution, while the rGO provides efficient transport pathways. The $\mathrm{rGO} / \mathrm{VO}_{2} / \mathrm{S}$ cathode with $\mathrm{rGO}$ wrapped yolk-shell $\mathrm{VO}_{2}$ sphere hybrid host delivered a capacity of $718.6 \mathrm{mAh} \mathrm{g}^{-1}$ initially, and $516.1 \mathrm{mAh} \mathrm{g}^{-1}$ over 400 cycles at $1 C$ [439].

Table 8. Summary of the electrochemical performance of $\mathrm{VO}_{2}(\mathrm{~B}) / \mathrm{rGO}$ composites. Relevant cycle number is given in brackets.

\begin{tabular}{|c|c|c|c|c|}
\hline Material & Synthesis & $\begin{array}{l}\text { Specific Capacity } \\
\left(m A h \mathrm{~g}^{-1}\right)\end{array}$ & $\begin{array}{l}\text { Current Density } \\
\quad\left(\mathrm{mA} \mathrm{g}^{-1}\right)\end{array}$ & Ref. \\
\hline \multicolumn{5}{|l|}{ Cathode } \\
\hline $\mathrm{VO}_{2}(\mathrm{~B}) / \mathrm{rGO}$ & hydrothermal $150^{\circ} \mathrm{C} / 12 \mathrm{~h}$ & 250 & $50(50)$ & [440] \\
\hline $\mathrm{VO}_{2}(\mathrm{~B}) / \mathrm{GO}$ & sonication + hydrothermal & 350 & $40(20)$ & [436] \\
\hline $\mathrm{VO}_{2.07} / \mathrm{rGO}$ & hydrothermal $180^{\circ} \mathrm{C} / 20 \mathrm{~h}$ & 133 & $70(200)$ & [426] \\
\hline $\mathrm{VO}_{2}(\mathrm{R}) \mathrm{rGO}$ & hydrothermal $190^{\circ} \mathrm{C} / 48 \mathrm{~h}$ & 85 & $20(100)$ & [430] \\
\hline $\mathrm{VO}_{2}(\mathrm{~B}) / \mathrm{rGO}$ & hydrothermal $180^{\circ} \mathrm{C} / 24 \mathrm{~h}$ & 130 & $1000(500)$ & [438] \\
\hline $\mathrm{VO}_{2}(\mathrm{~B}) / \mathrm{rGO}$ & single-step hydrothermal & 250 & $5000(1600)$ & [429] \\
\hline \multicolumn{5}{|l|}{ Anode } \\
\hline $\mathrm{VO}_{2}(\mathrm{~B}) / \mathrm{rGO}$ & microwave-assisted solvothermal & 400 & $200(400)$ & [422] \\
\hline $\mathrm{VO}_{2}(\mathrm{M}) / \mathrm{rGO}$ & sol-gel assisted hydrothermal & 283 & $60(200)$ & [424] \\
\hline GO-coated $\mathrm{VO}_{2}(\mathrm{~B})$ & sol-gel + calcination & 220 & $100(20)$ & [437] \\
\hline $\mathrm{VO}_{2}(\mathrm{~B}) / \mathrm{rGO}$ & hydrothermal $180^{\circ} \mathrm{C} / 24 \mathrm{~h}$ & 1214 & $100(120)$ & [434] \\
\hline
\end{tabular}

\subsection{2. $\mathrm{V}_{2} \mathrm{O}_{3}$-Based Composites}

$\mathrm{V}_{2} \mathrm{O}_{3}$ has been considered as anode material because of its high theoretical capacity of $1070 \mathrm{mAh} \mathrm{g}^{-1}$ and low discharge potential, but its application is hindered by the low conductivity and drastic volume 
change [441,442]. Leng et al. [443] prepared $3 \mathrm{D} \mathrm{V}_{2} \mathrm{O}_{3} / \mathrm{rGO}$ gels through a hydrothermal reaction and annealing process using $\mathrm{GO}$ and $\mathrm{NH}_{4} \mathrm{VO}_{3}$. These composites show a discharge capacity of $786 \mathrm{mAh} \mathrm{g}^{-1}$ under $0.07 \mathrm{~A} \mathrm{~g}^{-1}$ current density and good cycle stability. $\mathrm{V}_{2} \mathrm{O}_{3} / \mathrm{rGO}$ composites were fabricated by through a facile solvothermal method and annealing process; $\mathrm{V}_{2} \mathrm{O}_{3}$ nanoparticles (NPs, sizes of $5-40 \mathrm{~nm}$ ) are uniformly dispersed on rGO sheets without aggregation [444]. The $\mathrm{V}_{2} \mathrm{O}_{3} / \mathrm{rGO}$ nanocomposites achieves a reversible specific capacity of $823 \mathrm{mAh} \mathrm{g}^{-1}$ under the current density of $0.1 \mathrm{~A} \mathrm{~g}^{-1}$ in the potential range $0.01-3.0 \mathrm{~V}$ and maintains $407 \mathrm{mAh} \mathrm{g}^{-1}$ under the high current density of $4.0 \mathrm{~A} \mathrm{~g}^{-1}$. Using vanadyl oxalate $\left(\mathrm{VOC}_{2} \mathrm{O}_{4}\right)$ and $\mathrm{GO}$ prepared by a modified Hummers' method as starting precursors, $\mathrm{V}_{2} \mathrm{O}_{3} / \mathrm{rGO}$ composites were synthesized via solvothermal process in ethylene glycol and hydrothermal route at $200{ }^{\circ} \mathrm{C}$ for $12 \mathrm{~h}$ with subsequent annealing at $600{ }^{\circ} \mathrm{C}$ for $4 \mathrm{~h}$ in $\mathrm{H}_{2} / \mathrm{Ar}(8: 92)$ mixed atmosphere. Another specimen $\mathrm{V}_{2} \mathrm{O}_{3} / \mathrm{GO}$ was obtained by heat treatment in $100 \% \mathrm{Ar}$ ambient (i.e., without reducing atmosphere) [445]. The $\mathrm{V}_{2} \mathrm{O}_{3}-\mathrm{rGO}$ electrode yields a stable capacity of $380 \mathrm{mAh} \mathrm{g}^{-1}$ after 50 cycles at a current density of $0.1 \mathrm{~A} \mathrm{~g}^{-1}$, much higher than $280 \mathrm{mAh} \mathrm{g}^{-1}$ of $\mathrm{V}_{2} \mathrm{O}_{3}-\mathrm{GO}$. The rate capability as anode electrode provided capacities of 150,108 , and $97 \mathrm{mAh} \mathrm{g}^{-1}$ at current densities of 3, 9, and $15 \mathrm{~A} \mathrm{~g}^{-1}$, respectively. Liu and coworkers [446] performed an in-situ synthesis of $\mathrm{V}_{2} \mathrm{O}_{3}$ nanorods adhered to $\mathrm{rGO}$ via hydrothermal route and heat-treatment. Electrochemical features endow $\mathrm{V}_{2} \mathrm{O}_{3} / \mathrm{rGO}$ composite as advanced anode material for LIBs with good cycling stability, i.e., $675 \mathrm{mAh} \mathrm{g}^{-1}$ after 300 cycles at $0.5 \mathrm{~A} \mathrm{~g}^{-1}$ and excellent rate capability, i.e., $428 \mathrm{mAh} \mathrm{g}^{-1}$ at $2 \mathrm{~A} \mathrm{~g}^{-1}$. Xiao and coworkers [444] have successfully prepared $\mathrm{V}_{2} \mathrm{O}_{3} / \mathrm{rGO}$ nanocomposites through a solvothermal method and annealing process. The $\mathrm{V}_{2} \mathrm{O}_{3}$ nanoparticles (NPs, 5-40 nm in size) were uniformly dispersed and encapsulated by rGO sheets, which inhibits volume changes, improves the ion, and electronic conductivity of highly resistive $\mathrm{V}_{2} \mathrm{O}_{3}$ and avoids NPs aggregation. The electrochemical properties of $\mathrm{V}_{2} \mathrm{O}_{3} / \mathrm{rGO}$ investigated in the potential range 0.01-3.0 V show a reversible specific capacity of $823 \mathrm{mAh} \mathrm{g}^{-1}$ under the current density of $0.1 \mathrm{~A} \mathrm{~g}^{-1}$, and $407 \mathrm{mAh} \mathrm{g}^{-1}$ under the high current density of $4.0 \mathrm{~A} \mathrm{~g}^{-1}$.

\subsection{3. $\mathrm{V}_{2} \mathrm{O}_{5}$-Based Composites}

Vanadium pentoxide is a typical layered material, which is crystallized with the orthorhombic structure (Pmmn space group). $\mathrm{V}_{2} \mathrm{O}_{5}$ is a promising cathode material because of its $2 \mathrm{D}$ architecture, abundant sources, and high theoretical specific capacity $\left(294 \mathrm{mAh} \mathrm{g}^{-1}\right.$ for $2 \mathrm{Li}$ uptake into g- $\left.\mathrm{Li}_{\mathrm{x}} \mathrm{V}_{2} \mathrm{O}_{5}\right)$ but shows limiting electrochemical performance in regard to the low ionic diffusivity $\left(10^{-12}-10^{-13} \mathrm{~cm}^{2} \mathrm{~s}^{-1}\right)$ and moderate electrical conductivity $\left(10^{-2}-10^{-3} \mathrm{~S} \mathrm{~cm}^{-1}\right)$ [447]. Liu et al. [448] fabricated $\mathrm{V}_{2} \mathrm{O}_{5} / \mathrm{rGO}$ composites with two different morphologies, i.e., nanosheet or nanoparticle-assembled subunits (50-100 $\mathrm{nm}$ in-plane size) by adjusting the solvothermal solution as cathode materials for lithium-ion batteries. In the voltage range of $2.5-4.0 \mathrm{~V}$ vs. $\mathrm{Li}^{+} / \mathrm{Li}$, the nanosheet-assembled $\mathrm{V}_{2} \mathrm{O}_{5} / \mathrm{GO}$ hybrid delivered an initial capacity of $142 \mathrm{mAh} \mathrm{g}^{-1}$ at $2 \mathrm{C}$ rate and retained $85 \%$ of their original capacity at $1 \mathrm{C}$ rate after 500 cycles, while the nanoparticle-assembled $\mathrm{V}_{2} \mathrm{O}_{5} / \mathrm{GO}$ hybrid retained only $80 \mathrm{mAh} \mathrm{g} \mathrm{g}^{-1}$. The $\mathrm{V}_{2} \mathrm{O}_{5} / \mathrm{rGO}$ composites exhibited better rate capability and long-term cycling stability; they delivered capacities of $122 \mathrm{mAh} \mathrm{g}^{-1}$ at $64 \mathrm{C}$ rate. A two-step solvothermal method followed by vacuum annealing was employed to prepare mesoporous hybrids of $\mathrm{V}_{2} \mathrm{O}_{5}$ nanoparticles anchored on $\mathrm{rGO}$. This hybrid obtained by slow hydrolysis of vanadium oxytriisopropoxide $\left(\mathrm{C}_{9} \mathrm{H}_{24} \mathrm{O}_{4} \mathrm{~V}\right)$ had a hierarchical structure with 20-30 nm $\mathrm{V}_{2} \mathrm{O}_{5}$ nanoparticles uniformly deposited on rGO nanosheets, leading to a surface area of $24 \mathrm{~m}^{2} \mathrm{~g}^{-1}$ and average pore size of $20 \mathrm{~nm}$. The $\mathrm{V}_{2} \mathrm{O}_{5} / \mathrm{rGO}$ mesoporous hybrids were used as electrodes in symmetrical ESC (specific capacitance of $\sim 466 \mathrm{~F} \mathrm{~g}^{-1}$ in $1 \mathrm{~mol} \mathrm{~L}^{-1} \mathrm{Na}_{2} \mathrm{SO}_{4}$ electrolyte) and cathode of lithium battery (specific capacity of 295 and $132 \mathrm{mAh} \mathrm{g}^{-1}$ at C/9 and 10C rate, respectively). They showed excellent cycling stability with discharge capacity retention of $\sim 83 \%$ after 150 cycles at $1 \mathrm{C}$ rate [449]. Luo et al. prepared the $\mathrm{GO} / \mathrm{V}_{2} \mathrm{O}_{5}$-coated $\mathrm{LiNi}_{0.5} \mathrm{Co}_{0.2} \mathrm{Mn}_{0.3} \mathrm{O}_{2}(\mathrm{GO} / \mathrm{VO} / \mathrm{NCM})$ cathode material by a wet chemical method [450]. The composite consisted of a $\mathrm{V}_{2} \mathrm{O}_{5}$ inner layer of $5 \mathrm{~nm}$ and a GO outer layer of 5-9 $\mathrm{nm}$ thick. The double-layer-coated NCM cathode material (initial discharge capacity of $\sim 180 \mathrm{mAh}^{-1}$ ) showed improved electrochemical performance with a capacity retention 
of $74.2 \%$ after 50 cycles in a range of $2.5-4.5 \mathrm{~V}$ vs. $\mathrm{Li}^{+} / \mathrm{Li}$ at $55{ }^{\circ} \mathrm{C}$. Liu et al. developed a method to introduce GO sheets into $\mathrm{V}_{2} \mathrm{O}_{5}$ nanoribbons via sol-gel route [451]. The $2 \mathrm{wt} \% \mathrm{GO}$ containing composite delivered a specific capacity of $315 \mathrm{mAh} \mathrm{g}^{-1}$ at $1 \mathrm{C}$ rate and showed good cyclability over 200 cycles with a capacity decay of $0.13 \mathrm{mAh} \mathrm{g}^{-1}$ per cycle. For the micro-nanosized $\mathrm{V}_{2} \mathrm{O}_{5} / \mathrm{rGO}$ composites that were fabricated by the hydrothermal treatment of the mixture of $\mathrm{V}_{2} \mathrm{O}_{5}$, cetyltrimethyl ammonium bromide, and GO dispersed in aqueous solution kept at $190^{\circ} \mathrm{C}$ for $48 \mathrm{~h}$ [430], the initial charge capacity was $235 \mathrm{mAh} \mathrm{g}^{-1}$ at $20 \mathrm{~mA} \mathrm{~g}^{-1}$ current rate and $235 \mathrm{mAh} \mathrm{g}^{-1}$ was retained after 100 cycles. A simple solvothermal technique was used to prepare self-assembled $\mathrm{V}_{2} \mathrm{O}_{5}$ nanosheets (NSs)/rGO nanocomposite with high specific area of $40 \mathrm{~m}^{2} \mathrm{~g}^{-1}$. The $\mathrm{V}_{2} \mathrm{O}_{5} \mathrm{NSs} / \mathrm{rGO}$ anode cycled at 3 and $15 \mathrm{~A} \mathrm{~g}^{-1}$ current densities delivered specific capacities of 138 and $76 \mathrm{mAh} \mathrm{g}^{-1}$, respectively. When discharged at $2 \mathrm{C}$ rate a discharge capacity of $102 \mathrm{mAh} \mathrm{g}^{-1}$ was obtained after 160 cycles [452]. Highly porous polycrystalline $\mathrm{V}_{2} \mathrm{O}_{5} / \mathrm{rGO}$ hybrids were grown through heterogeneous nucleation of $\mathrm{V}_{2} \mathrm{O}_{5}$ nanoparticles $(10-50 \mathrm{~nm}$ ) on rGO sheets by using a solvothermal method followed by an annealing process [453]. In the voltage range of 4.0-2.0 V, the cathode performance of the as-prepared $\mathrm{V}_{2} \mathrm{O}_{5} / \mathrm{rGO}\left(46 \mathrm{wt}^{\circ}\right)$ was $102 \mathrm{mAh} \mathrm{g}^{-1}$ at a high current density of $5700 \mathrm{~mA} \mathrm{~g}^{-1}$ after 2000 cycles. $\mathrm{A} \mathrm{V}_{2} \mathrm{O}_{5}$-reduced graphene ball composite was formed by the post-annealing of $\mathrm{VO}_{2} / \mathrm{rGO}$ hybrid at $300{ }^{\circ} \mathrm{C}$ in air [425]. Hu and coworkers [454] synthesized uniform wrinkle $\mathrm{V}_{2} \mathrm{O}_{5} / \mathrm{GO}$ flexible thin films via a drop-casting technique with subsequent annealing process. The optimized films with mass ratio (8:1) of $\mathrm{V}_{2} \mathrm{O}_{5}$ and GO exhibited a specific capacitance of $397 \mathrm{~F} \mathrm{~g}^{-1}$ at a current density of $1 \mathrm{~A} \mathrm{~g}^{-1}$ and cycling stability with $98 \%$ retention over 2000 cycles at $5 \mathrm{~A} \mathrm{~g}^{-1}$ rate. With $5 \mathrm{wt} \%$ graphene, the initial discharge capacity of $\mathrm{V}_{2} \mathrm{O}_{5} / \mathrm{rGO}$ was $282 \mathrm{mAh} \mathrm{g}^{-1}$ with a coulombic efficiency of $99 \%$. This cathode material delivered a capacity of $214 \mathrm{mAh} \mathrm{g}^{-1}$ at $1 \mathrm{~A} \mathrm{~g}^{-1}$ after 100 cycles. $\mathrm{V}_{2} \mathrm{O}_{5} / \mathrm{rGO}$ composites were formed by wet mixing the electrospun $\mathrm{V}_{2} \mathrm{O}_{5}$ nanowires (100-200 $\mathrm{nm}$ in diameter and $\mu \mathrm{m}$ length) [455]. The $\mathrm{V}_{2} \mathrm{O}_{5} / \mathrm{rGO}$ composite with $1 \mathrm{wt} \%$ rGO showed the 1 st and 60th discharge capacities of 225 and $125 \mathrm{mAh} \mathrm{g}^{-1}$, respectively, at C/5 rate. Recently, Kurc et al. [456] investigated the impact of the addition $\mathrm{V}_{\mathrm{x}} \mathrm{O}_{\mathrm{y}}$ nanoparticles (50-150 nm) in $\mathrm{TiO}_{2} / \mathrm{rGO}$ composite electrode synthesized by solvothermal method. Incorporation of $4.5 \mathrm{wt} \% \mathrm{~V}_{\mathrm{x}} \mathrm{O}_{\mathrm{y}}$ in $\mathrm{TiO}_{2} / \mathrm{rGO}$ was beneficial in terms of the cell stability. This electrode showed a reversible capacity of $182 \mathrm{mAh} \mathrm{g}^{-1}$ at $50 \mathrm{~mA} \mathrm{~g}^{-1}$ current density and $118 \mathrm{mAh} \mathrm{g}^{-1}$ at $500 \mathrm{~mA} \mathrm{~g}^{-1}$. A full cell with $\mathrm{LiFePO}_{4} / / \mathrm{V}_{\mathrm{x}} \mathrm{O}_{\mathrm{y}}-\mathrm{TiO}_{2} / \mathrm{rGO}$ electrochemical chain showed good cycle ability while providing a capacity of $120 \mathrm{mAh} \mathrm{g}^{-1}$. The cell did not lose significant capacity upon extended cycling. Electrochemical performance of $\mathrm{V}_{2} \mathrm{O}_{5} / \mathrm{rGO}$ composites as electrodes for LIBs from the recent literature are summarized in Table 9.

Table 9. Comparison of the $\mathrm{V}_{2} \mathrm{O}_{5} / \mathrm{rGO}$-type materials with preparation methods. Relevant cycle number is given in brackets.

\begin{tabular}{llccc}
\hline \multicolumn{1}{c}{ Material } & \multicolumn{1}{c}{ Synthesis } & $\begin{array}{c}\text { Specific Capacity } \\
\left(\mathbf{m} \mathbf{A h} \mathbf{~ g}^{-\mathbf{1}} \mathbf{)}\right.\end{array}$ & $\begin{array}{c}\text { Current Rate } \\
\left(\mathbf{m} \mathbf{A} \mathbf{~ g}^{-\mathbf{1}}\right)\end{array}$ & Ref. \\
\hline $\mathrm{V}_{2} \mathrm{O}_{5} / \mathrm{GO} / \mathrm{NCM}$ & wet chemistry & 125 & 55 & {$[450]$} \\
$\mathrm{V}_{2} \mathrm{O}_{5} / \mathrm{rGO}$ & solvothermal solution & 122 & $64 \mathrm{C}(500)$ & {$[448]$} \\
$\mathrm{V}_{2} \mathrm{O}_{5} / \mathrm{rGO}$ & two-step solvothermal & 205 & $1 \mathrm{C}(120)$ & {$[449]$} \\
$\mathrm{V}_{2} \mathrm{O}_{5} / \mathrm{GO}(2 \mathrm{wt} /)$ & sol-gel & 240 & $1 \mathrm{C}(200)$ & {$[451]$} \\
$\mathrm{V}_{2} \mathrm{O}_{5} / \mathrm{rGO}(3.2 \%)$ & hydrothermal & 175 & $20(100)$ & {$[430]$} \\
$\mathrm{V}_{2} \mathrm{O}_{5} \mathrm{NSs} / \mathrm{rGO}$ & solvothermal & 141 & $600(160)$ & {$[452]$} \\
$\mathrm{V}_{2} \mathrm{O}_{5} / \mathrm{rGO}$ & solvothermal & 102 & $5700(200)$ & {$[453]$} \\
$\mathrm{V}_{2} \mathrm{O}_{5} \mathrm{NRs} / \mathrm{rGO}$ & hydrothermal + reflux & 140 & $150(100)$ & {$[457]$} \\
$\mathrm{V}_{2} \mathrm{O}_{5} / \mathrm{rGO}$ & post-annealing of $\mathrm{VO}_{2} / \mathrm{rGO}$ & 214 & $1000(100)$ & {$[425]$} \\
$\mathrm{V}_{2} \mathrm{O}_{5} / \mathrm{rGO}$ & electrospinning & 125 & $\mathrm{C} / 5(60)$ & {$[455]$} \\
$\mathrm{V}_{\mathrm{x}} \mathrm{O}_{\mathrm{y}}-\mathrm{TiO} 2 / \mathrm{rGO}$ & solvothermal & 180 & $50(20)$ & {$[456]$} \\
\hline
\end{tabular}

Yan et al. [458] reported the fabrication of a crumpled rGO (c-rGO) encapsulated 3D hollow $\mathrm{V}_{2} \mathrm{O}_{5}$ nano/microspheres using one-step solvothermal process followed by subsequent annealing. The as-prepared c-rGO/ $\mathrm{V}_{2} \mathrm{O}_{5}$ composite containing $5 \mathrm{wt} \%$ rGO delivered reversible capacities of 289 
and $163 \mathrm{mAh} \mathrm{g}^{-1}$ at current densities of 0.1 and $5.0 \mathrm{~A} \mathrm{~g}^{-1}$, respectively, as well as a capacity retention of about $94 \%$ after 200 cycles at $2 \mathrm{~A} \mathrm{~g}^{-1}$ in the potential range $2.0-4.0 \mathrm{~V} \mathrm{vs.} \mathrm{Li}^{+} / \mathrm{Li}$. Wang et al. [459] investigated the $\mathrm{V}_{2} \mathrm{O}_{5}$ nanobelts/rGO composites as positive electrode for aqueous zinc-ion battery (ZIB). While the commercial $\mathrm{V}_{2} \mathrm{O}_{5}$ powders show poor cycle stability and low specific capacity of $30 \mathrm{mAh} \mathrm{g}^{-1}$ after 200 cycles, $\mathrm{V}_{2} \mathrm{O}_{5} / \mathrm{rGO}$ nanocomposites delivered a high specific capacity of $135 \mathrm{mAh} \mathrm{g}^{-1}$ after 200 cycles at a current density of $0.1 \mathrm{~A} \mathrm{~g}^{-1}$. The rate capability test yielded a capacity of $113 \mathrm{mAh} \mathrm{g}^{-1}$ when a current density of $1 \mathrm{~A} \mathrm{~g}^{-1}$ was applied. Du et al. [460] developed $\mathrm{GO} / \mathrm{V}_{2} \mathrm{O}_{5}$ composites as cathode materials for rechargeable magnesium batteries via solvothermal synthesis using vanadium oxytriisopropoxide and graphene oxide. The composites attain a high discharge capacity of $178 \mathrm{mAh} \mathrm{g}^{-1}$ at $0.2 \mathrm{C}$ rate and $140 \mathrm{mAh} \mathrm{g}^{-1}$ after 20 cycles in the potential range 1.0-2.8 V. The $\mathrm{GO} / \mathrm{V}_{2} \mathrm{O}_{5}$ composite can host $0.6 \mathrm{Mg}$ ions per formula unit.

The $\mathrm{V}_{3} \mathrm{O}_{7} / \mathrm{GO}$ nanocomposites, with the $\mathrm{V}_{3} \mathrm{O}_{7}$ nanobelts of $12 \mathrm{~nm}$ in width and several $\mu \mathrm{m}$ in length were prepared by a hydrothermal method. The electrochemical tests of these electrode in $\mathrm{Li}$ cells showed a first discharge capacity of $352 \mathrm{mAh} \cdot \mathrm{g}^{-1}$ at the current density of $100 \mathrm{~mA} \cdot \mathrm{g}^{-1}$ and a good cycling performance with $87 \%$ and $91 \%$ capacity retention upon 50 cycles at the current density of 400 and $800 \mathrm{~mA} \cdot \mathrm{g}^{-1}$, respectively [461].

Numerous reports are related to the $\mathrm{V}_{2} \mathrm{O}_{5} / \mathrm{rGO}$ composites applied as electrodes of electrochemical ESCs. Ramadoss et al. reported the fabrication of a $\mathrm{V}_{2} \mathrm{O}_{5} / \mathrm{rGO}$ electrode, which displayed a maximum specific capacitance of $250 \mathrm{~F} \mathrm{~g}^{-1}$ at $5 \mathrm{mV} \mathrm{s}^{-1}$ scan rate retaining $95 \%$ of its initial value after 5000 cycles [462]. A bifunctional composite hydrogel containing $\mathrm{rGO}$ nanosheets and $\mathrm{V}_{2} \mathrm{O}_{5}$ nanobelts $\left(\mathrm{rGO} / \mathrm{V}_{2} \mathrm{O}_{5}\right)$ was successfully prepared by a hydrothermal method at $180{ }^{\circ} \mathrm{C}$ for $12 \mathrm{~h}$ with $\mathrm{GO}$ and aqueous $\mathrm{V}_{2} \mathrm{O}_{5}$ precursors as raw materials followed by a freeze-drying process [463]. The $\mathrm{rGO} / \mathrm{V}_{2} \mathrm{O}_{5}$ composite exhibited outstanding performance for ESCs, providing a specific capacitance of $\sim 320 \mathrm{~F} \mathrm{~g}^{-1}$ at a current density of $1 \mathrm{~A} \mathrm{~g} \mathrm{~g}^{-1}$ for $\mathrm{V}_{2} \mathrm{O}_{5}$ mass loading of $67.3 \mathrm{wt} \%$. Foo et al. [464] eliminated the need for current collectors or additives and reducing resistance (sheet resistance $29.1 \Omega \mathrm{sq}^{-1}$ ) by constructing $\mathrm{V}_{2} \mathrm{O}_{5} / \mathrm{rGO}$ free-standing hybrid electrodes for ESC applications. The effective exfoliation of rGO achieved high areal capacitance of $511 \mathrm{mF} \mathrm{cm}^{-2}$ coupled with high mass loadings. An asymmetric flexible supercapacitor based on the $\mathrm{rGO} / \mathrm{V}_{2} \mathrm{O}_{5}-\mathrm{rGO}$ configuration delivered a low equivalent series resistance (ESR) of $3.36 \Omega$. Zhang et al. [465] prepared $\mathrm{V}_{2} \mathrm{O}_{5}-\mathrm{rGO}$ composites using a two-step reduction method with $\mathrm{V}_{2} \mathrm{O}_{5}$ nanowires (as long as $\sim 1 \mathrm{~mm}$ ) as the skeleton and rGO nanosheets as the additive. The product had an electrical conductivity of $1.62 \mathrm{~S} \mathrm{~cm}^{-1}$, which is higher than that of the pure $\mathrm{V}_{2} \mathrm{O}_{5}$ nanowire $\left(0.049 \mathrm{~S} \mathrm{~cm}^{-1}\right)$. Studied as cathode for Li-ion battery, the free-standing $\mathrm{V}_{2} \mathrm{O}_{5} / \mathrm{rGO}$ composite showed a reversible specific areal capacity of $885 \mu \mathrm{Ah} \mathrm{cm} \mathrm{cm}^{-2}$ at $0.09 \mathrm{~mA} \mathrm{~cm}-2$. When tested at a high current rate of $0.9 \mathrm{~mA} \mathrm{~cm}{ }^{2}$, it gave excellent cycling performance with a retention of $\sim 69 \%$ after 1000 cycles. Table 10 summarizes the electrochemical performance of $\mathrm{V}_{2} \mathrm{O}_{5}$ /graphene composites as electrodes for supercapacitors

Table 10. Comparison of the $\mathrm{V}_{2} \mathrm{O}_{5}$ /graphene composites as electrodes for electrochemical supercapacitors (ESCs).

\begin{tabular}{|c|c|c|c|c|c|}
\hline Material & Synthesis & $\begin{array}{l}\text { Capacitance } \\
\qquad\left(\mathrm{F} \mathrm{g}^{-1}\right)\end{array}$ & $\begin{array}{c}\text { Rate } \\
\left(\mathrm{mA} \mathrm{g}^{-1}\right)\end{array}$ & Electrolyte & Ref. \\
\hline $\mathrm{V}_{2} \mathrm{O}_{5} / \mathrm{rGO}$ & solvothermal & 537 & 1000 & $8 \mathrm{M} \mathrm{LiCl}$ & [466] \\
\hline $\mathrm{VO}_{2} / \mathrm{rGO}$ & hydrothermal & 225 & 250 & $0.5 \mathrm{M} \mathrm{K}_{2} \mathrm{SO}_{4}$ & [467] \\
\hline $\mathrm{VO}_{\mathrm{x}} \mathrm{NTs} / \mathrm{rGO}$ & hydrothermal & 210 & 1000 & $1 \mathrm{M} \mathrm{Na}_{2} \mathrm{SO}_{4}$ & [468] \\
\hline $\mathrm{VO}_{2} \mathrm{NBs} / \mathrm{rGO}$ & hydrothermal & 426 & 1000 & $0.5 \mathrm{M} \mathrm{K}_{2} \mathrm{SO}_{4}$ & [469] \\
\hline $\mathrm{V}_{2} \mathrm{O}_{5} \mathrm{NWs} / \mathrm{rGO}$ & hydrothermal & 80 & 500 & 1M LiTFSI & [470] \\
\hline $\mathrm{VO}_{\mathrm{x} / \mathrm{rGO}}$ & solvothermal & 183 & 500 & $0.5 \mathrm{M} \mathrm{Na}_{2} \mathrm{SO}_{4}$ & [471] \\
\hline $\mathrm{V}_{2} \mathrm{O}_{5} / \mathrm{rGO}$ & hydrothermal & 130 & 100 & $1 \mathrm{M} \mathrm{LiClO}_{4}$ & [464] \\
\hline $\mathrm{V}_{2} \mathrm{O}_{5} / \mathrm{rGO}$ & coprecipitation & 484 & 500 & $0.5 \mathrm{M} \mathrm{K}_{2} \mathrm{SO}_{4}$ & [472] \\
\hline $\mathrm{V}_{2} \mathrm{O}_{5} / \mathrm{rGO}$ & solvothermal & 450 & 500 & $1 \mathrm{M} \mathrm{Na}_{2} \mathrm{SO}_{4}$ & [449] \\
\hline $\mathrm{V}_{2} \mathrm{O}_{5} \mathrm{NRs} / \mathrm{rGO}$ & sol-gel & 218 & 5000 & $1 \mathrm{M} \mathrm{Na}_{2} \mathrm{SO}_{4}$ & [473] \\
\hline
\end{tabular}




\subsection{4. $\mathrm{VPO}_{4}$-Based Composites}

Among the polyanionic anode materials, vanadyl phosphate, $\mathrm{VPO}_{4}$, is considered as a promising anode material because of the excellent chemical activity of vanadium with a relatively high theoretical specific capacity ( $550 \mathrm{mAh} \mathrm{g}^{-1}$ ) [474]. The lithiation/delithiation mechanism is a conversion reaction involving three electrons. Combined with $\mathrm{rGO}, \mathrm{VPO}_{4}$ as electrode of both LIBs and ESCs has shown significant improvement in their electrochemical performances [475,476]. Lu et al. [476] developed a $3 \mathrm{D}$ hydrangea-like vanadium phosphate microspheres embedded in the interlaced multiporous rGO scaffold $\left(\mathrm{VPO}_{4} / \mathrm{rGO}\right)$ to form self-supporting porous anodes for lithium-ion batteries. The $\mathrm{VPO}_{4} / \mathrm{rGO}$ samples were synthesized by in-situ solvothermal reduction method using a mixture of GO and $\mathrm{VOPO}_{4} \cdot 2 \mathrm{H}_{2} \mathrm{O}$ acting as reductant and dispersant followed by a hydrothermal treatment at $180{ }^{\circ} \mathrm{C}$ for $24 \mathrm{~h}$. The porous microspheres with $80 \% \mathrm{VPO}_{4}$ had a specific surface area of $\sim 87 \mathrm{~m}_{2} \mathrm{~g}^{-1}$ and half pore width of $\sim 35 \mathrm{~nm}$. The as prepared $\mathrm{VPO}_{4} / \mathrm{rGO}-80 \%$ electrode displayed a fast-charging specific capacity of $537 \mathrm{mAh} \mathrm{g}^{-1}$ at $0.1 \mathrm{~A} \mathrm{~g}^{-1}$ (weight based on whole electrode), and long-life performance of $318 \mathrm{mAh} \mathrm{g}^{-1}$ after 3000 cycles at $2 \mathrm{~A} \mathrm{~g}^{-1}$ (Figure 14). Through differentiating the contribution from pseudocapacitance and diffusion-controlled process, the authors demonstrated that the charge-discharge mechanism was dominated by the pseudocapacitance.
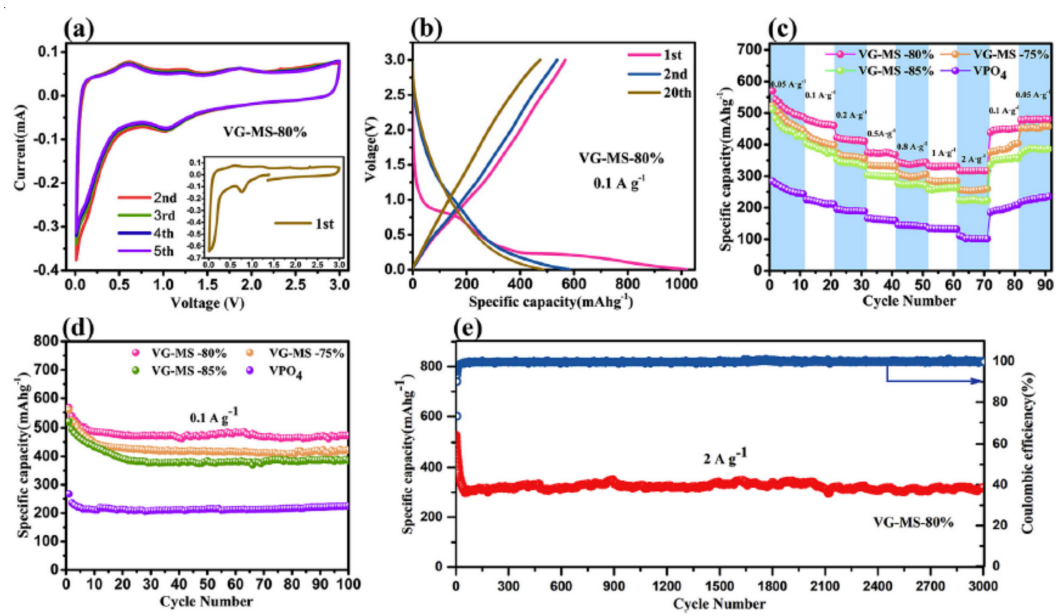

Figure 14. Electrochemical properties of $\mathrm{VPO}_{4} / \mathrm{rGO}-80 \%$ composites. (a) Cyclic voltammograms for the first five cycles, (b) charge-discharge voltage profiles for selected cycles at a current density of $0.1 \mathrm{~A} \mathrm{~g}^{-1}$, (c) rate, and (d) cycling performance of VG-MS-75\%, VG-MS-80\%, VG-MS-85\%, and $\mathrm{VPO}_{4}$, (e) cycling and efficiency performance of VG-MS- $80 \%$ at $2 \mathrm{~A} \mathrm{~g}^{-1}$. All the specific capacity values are calculated based on the weight of the composite of VG-MS (also the weight of the electrode). Reproduced with permission from [476]. Copyright 2020 Elsevier.

\subsection{Cobalt-Based Oxide Composites}

\subsection{1. $\mathrm{Co}_{3} \mathrm{O}_{4}$-Based Composites}

$\mathrm{Co}_{3} \mathrm{O}_{4}$ has attracted extensive interest due to its high specific capacity of $890 \mathrm{mAh} \mathrm{g} \mathrm{g}^{-1}$ (i.e., electrochemical conversion reaction $\mathrm{Co}_{3} \mathrm{O}_{4}+8 \mathrm{Li}^{+}+8 \mathrm{e}^{-} \leftrightarrow 3 \mathrm{Co}+4 \mathrm{Li}_{2} \mathrm{O}$ to form lithium oxide and metal nanoparticles). However, similarly to other $\mathrm{TM}$ oxides, $\mathrm{Co}_{3} \mathrm{O}_{4}$ suffers from large volume expansion/contraction and loss of interparticle contact due to electrode pulverization upon lithiation [477].

The most common technique utilized for the synthesis of $\mathrm{Co}_{3} \mathrm{O}_{4} / \mathrm{rGO}$ composite is the hydrothermal method, which follows the preparation of a primary solution of GO with the cobalt precursor. For example, Kumar et al. [478] fabricated a ternary $\mathrm{Co}_{3} \mathrm{O}_{4} / \mathrm{rGO} / \mathrm{CNTs}$ nanocomposite for supercapacitor application using a three-step procedure: (i) Mixture of $\mathrm{Co}\left(\mathrm{NO}_{3}\right)_{2} \cdot 6 \mathrm{H}_{2} \mathrm{O}$ with a GO/CNTs dispersion and urea as reducing agent for $\mathrm{GO}$ with adjustment of the $\mathrm{pH}$ at 10 using ammonia, (ii) hydrothermal 
process at $180{ }^{\circ} \mathrm{C}$ for $8 \mathrm{~h}$ and (iii) after washing and drying then an annealing treatment at $300{ }^{\circ} \mathrm{C}$ in $\mathrm{N}_{2}$ environment for $3 \mathrm{~h}$ yields the final product. Another popular technique of fabrication is the one-pot microwave-assisted synthesis. Typical experiments are carried out in a domestic microwave at a power of $1600 \mathrm{~W}$ for $30 \mathrm{~min}$ [479].

A rough comparison of early reports indicates that the $\mathrm{Co}_{3} \mathrm{O}_{4} / \mathrm{rGO}$ composite displayed superior electrochemical performances. The $\mathrm{Co}_{3} \mathrm{O}_{4} / \mathrm{rGO}$ sheet-on-sheet nanocomposite prepared by microwave-assisted synthesis presents a capacity of $931 \mathrm{mAh} \mathrm{g}^{-1}$ at a large current rate of $5 \mathrm{C}$

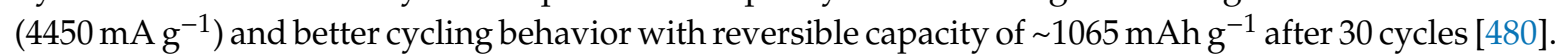
Yang et al. [481] have described a self-assembly approach to prepare tailored graphene-encapsulated, mesoporous $\mathrm{Co}_{3} \mathrm{O}_{4}$ microspheres. The nanocasting method produces a composite with full wrapping by graphene shells, which delivers a first discharge capacity of $1533 \mathrm{mAh} \mathrm{g}^{-1}$ and rapidly stabilizes. A high reversible capacity of about $820 \mathrm{mAh} \mathrm{g}^{-1}$ was achieved after 35 cycles at a current of $100 \mathrm{~A} \mathrm{~g}^{-1}$. $\mathrm{Wu}$ et al. [482] synthesized the composite of $\mathrm{Co}_{3} \mathrm{O}_{4}$ nanoparticles (10-30 nm in size) anchored on conducting rGO sheets via a one-step approach. The $\mathrm{Co}_{3} \mathrm{O}_{4} / \mathrm{rGO}$ hybrid anode displays a discharge capacity of $935 \mathrm{mAh} \mathrm{g}^{-1}$ was obtained after 30 cycles. Zhang et al. [483] also reported the deposition of $\mathrm{Co}_{3} \mathrm{O}_{4}$ and the exfoliation of graphene sheets in a one-step electrochemical process. The $\mathrm{Co}_{3} \mathrm{O}_{4} / \mathrm{rGO}$ composite as an anode material yields a reversible discharge capacity of about $880 \mathrm{mAh} \mathrm{g}^{-1}$ for 40 cycles at $0.3 \mathrm{C}$ rate.

Using a convenient PVP (polyvinylpyrrolidone)-assisted method under reflux conditions, Pan et al. [484] prepared a $\mathrm{Co}_{3} \mathrm{O}_{4} / \mathrm{rGO}$ composite, which consists of uniform $\mathrm{Co}_{3} \mathrm{O}_{4}$ nanoparticles $(\sim 100 \mathrm{~nm})$ tightly enwrapped by rGO in the presence of the PVP surfactant. The $\mathrm{Co}_{3} \mathrm{O}_{4} \mathrm{NPs} / \mathrm{rGO} / \mathrm{PVP}$ composite exhibits superior Li-battery performance with large discharge capacity of $860 \mathrm{mAh} \mathrm{g}^{-1}$ during 120 cycles at $40 \mathrm{~mA} \mathrm{~g}^{-1}$ rate. Mesoporous $\mathrm{Co}_{3} \mathrm{O}_{4}$ nanosheets $\left(\mathrm{Co}_{3} \mathrm{O}_{4}-\mathrm{NSs}\right)$ and nitrogen-doped reduced graphene oxide $(\mathrm{N}-\mathrm{rGO})$ were prepared through a facile hydrothermal approach, and the $\mathrm{N}-\mathrm{rGO} / \mathrm{Co}_{3} \mathrm{O}_{4}$-NSs composite was fabricated using an infiltration procedure. The 2D/2D nanostructured mesoporous $\mathrm{N}-\mathrm{rGO} / \mathrm{Co}_{3} \mathrm{O}_{4}$-NSs composite was evaluated in a half-cell as an anode material delivering a reversible capacity of 1305 and $1501 \mathrm{mAh} \mathrm{g}^{-1}$ at a current density of $80 \mathrm{~mA} \mathrm{~g}^{-1}$ for the 1st and 50th cycles, respectively [27]. Lou et al. [485] prepared $\mathrm{a} \mathrm{Co}_{3} \mathrm{O}_{4} / \mathrm{rGO}$ anode material with a specific surface area of $149.5 \mathrm{~m}^{2} \mathrm{~g}^{-1}$ composed of ultra-small $\mathrm{Co}_{3} \mathrm{O}_{4}$ nanoparticles ( 12.5 nm in size) anchored on rGO nanosheets. The $\mathrm{Co}_{3} \mathrm{O}_{4} / \mathrm{rGO}$ containing $\sim 40 \mathrm{wt} \%$ rGO nanocomposite shows excellent electrochemical performances with a high reversible discharge capacity of $830 \mathrm{mAh} \mathrm{g}^{-1}$ after 75 cycles at $200 \mathrm{~mA} \mathrm{~g}^{-1}$, and a reversible capacity of $681 \mathrm{mAh} \mathrm{g}^{-1}$ after 30 cycles at $200 \mathrm{~mA} \mathrm{~g}^{-1}$ and 100 consecutive cycles at $500 \mathrm{~mA} \mathrm{~g}^{-1}$. Rate capability measurements displays reversible specific capacities of about 1153, 961.0, 851, and $736 \mathrm{mAh} \mathrm{g}^{-1}$ after each eight cycles at 50, 100, 200, and $500 \mathrm{~mA} \mathrm{~g}^{-1}$, respectively.

Cho et al. [486] highlighted the enhanced conversion reaction of the $\mathrm{Co}_{3} \mathrm{O}_{4} \mathrm{NFs} @ \mathrm{rGO}$ composite composed of $1 \mathrm{D} \mathrm{Co}_{3} \mathrm{O}_{4}$ nanofibers (NFs, 150-200 nm in diameter) covered with low content $(\sim 3.5 \mathrm{wt} \%)$ rGO ultrathin sheets $(\sim 3 \mathrm{~nm})$ by electrostatic self-assembly. To ensure efficient graphene wrapping, the surface of the $\mathrm{Co}_{3} \mathrm{O}_{4} \mathrm{NFs}$ was functionalized to amine group poly(allylamine hydrochloride) (PAH). The $\mathrm{Co}_{3} \mathrm{O}_{4} \mathrm{NF} / \mathrm{rGO}$ composite presents a high reversible capacity of $615 \mathrm{mAh} \mathrm{g}^{-1}$ and $92 \%$ capacity retention after 400 cycles at $4.0 \mathrm{Ag}^{-1}$ and displays excellent rate capability. Kesavan et al. [487] fabricated a nanocomposite anode composed of hollow $\mathrm{Co}_{3} \mathrm{O}_{4}$ nanospheres (h- $\mathrm{Co}_{3} \mathrm{O}_{4} \mathrm{NSs}$ ) combined with CNTs and rGO using a sonication method followed by a hydrothermal treatment. The h- $\mathrm{Co}_{3} \mathrm{O}_{4} \mathrm{NSs}(27 \mathrm{~nm}$ in size) were prepared by self-assembly process using poly(styrene-b-2-vinylpyridine-b-ethylene oxide) micelle as a soft template and $\left(\mathrm{NH}_{4}\right)_{2} \mathrm{Co}\left(\mathrm{SO}_{4}\right)_{2} \cdot 6 \mathrm{H}_{2} \mathrm{O}$ as cobalt source. The nanocomposite h-Co $\mathrm{O}_{4}$ $\mathrm{NSs} / \mathrm{CNT} / \mathrm{rGO}$ electrode exhibits higher charge/discharge capacities of $\sim 943 \mathrm{mAh} \mathrm{g}^{-1}$ when compared to pristine h- $\mathrm{Co}_{3} \mathrm{O}_{4} \mathrm{NSs}-$ based electrode $\left(\sim 678 \mathrm{mAh} \mathrm{g}{ }^{-1}\right)$ after 50 cycles. Park et al. [488] utilized a one-pot microwave-assisted hydrothermal method for the preparation of $\mathrm{Co}_{3} \mathrm{O}_{4} / \mathrm{rGO}$ nanocomposites. The $\mathrm{Co}_{3} \mathrm{O}_{4}$ nanoparticles (10-30 nm in size) uniformly decorated the surface of rGO sheets, which act as $2 \mathrm{D}$ template. The $\mathrm{Co}_{3} \mathrm{O}_{4} / \mathrm{rGO}$ hybrid anode containing $79 \mathrm{wt} \% \mathrm{Co}_{3} \mathrm{O}_{4}$ was tested galvanostatically in the voltage range $0.01-3.0 \mathrm{~V}$ using a 2032-type coin cell. It delivers a first discharge capacity 
of $947 \mathrm{mAh} \mathrm{g}^{-1}$ at $1 \mathrm{~A} \mathrm{~g}^{-1}$ current rate. The excellent cyclability was observed after 100 cycles at $0.5 \mathrm{~A} \mathrm{~g}^{-1}$ rate, and the specific discharge capacity is still as high as $683 \mathrm{mAh} \mathrm{g}^{-1}$, which is almost the second discharge capacity $\left(685 \mathrm{mAh} \mathrm{g}^{-1}\right)$. The suitability of $\mathrm{Co}_{3} \mathrm{O}_{4} / \mathrm{rGO}$ hybrid as cathode material of rechargeable aluminum-ion batteries has been demonstrated by Zhang et al. [489]. The composite was synthesized by a spontaneous self-assembly process using precursor made from the coprecipitation of the $\mathrm{Co}^{2+}$ - hexacyanocobaltate (II) metal-organic framework. The self-assembled $\mathrm{Co}_{3} \mathrm{O}_{4} / \mathrm{rGO}$ products were further annealed at $500{ }^{\circ} \mathrm{C}$ in Ar atmosphere for $2 \mathrm{~h}$. After the initial activation phase, an $\mathrm{Co}_{3} \mathrm{O}_{4} / \mathrm{rGO} \| \mathrm{Al}$ cell retains discharge capacity of $168 \mathrm{mAh} \mathrm{g}^{-1}$ and coulombic efficiency of $76 \%$ over 500 cycles of charge/discharge.

More recently, Mussa et al. [490] used a microwave irradiation technique to prepare $\mathrm{Co}_{3} \mathrm{O}_{4} / \mathrm{rGO} /$ hexagonal boron nitride ( $\mathrm{h}-\mathrm{BN}$ ) nanocomposites as anodes for high-temperature LIBs. The addition of h-BN not only enhances the thermal stability but also increases the specific surface area $\left(191 \mathrm{~m}^{2} \mathrm{~g}^{-1}\right)$ of composites. The $\mathrm{Co}_{3} \mathrm{O}_{4} / \mathrm{rGO} / \mathrm{h}-\mathrm{BN}$ electrode cycled at $208 \mathrm{~mA} \mathrm{~g}^{-1}$ in the voltage range $0.5-2.7 \mathrm{~V}$ displays a first specific capacity of $758 \mathrm{mAh} \mathrm{g}^{-1}$ maintained at $266 \mathrm{mAh} \mathrm{g}^{-1}$ after 100 cycles higher than $186 \mathrm{mAh} \mathrm{g}^{-1}$ for the $\mathrm{Co}_{3} \mathrm{O}_{4} / \mathrm{rGO}$ hybrid.

The use nitrogen-doped rGO (N-rGO) is a promising strategy for the development of anode materials for LIBs with high electrochemical performance [491,492]. Li et al. [492] designed a $\mathrm{Co}_{3} \mathrm{O}_{4} / \mathrm{N}-\mathrm{rGO}$ composite, in which ultrafine $\mathrm{Co}_{3} \mathrm{O}_{4}$ nanocrystals $(5-10 \mathrm{~nm})$ are homogeneously attached without aggregation to $\mathrm{N}-\mathrm{rGO}$ sheets by hydrothermal method. In this synthesis, ammonia acts as nitrogen dopant. The charge/discharge cycling performance of the $\mathrm{Co}_{3} \mathrm{O}_{4} / \mathrm{N}-\mathrm{rGO}$ anode shows a capacity of $882 \mathrm{mAh} \mathrm{g}^{-1}$ at the 6th cycle at $400 \mathrm{~A} \mathrm{~g}^{-1}$, which gradually decreases down $766 \mathrm{mAh} \mathrm{g}^{-1}$ at the 50th cycle. Rate capability tests show discharge capacities of 1100, 950, 860, 670, and $460 \mathrm{mAh} \mathrm{g}^{-1}$ at different current densities of 100, 200, 400, 1000, and $2000 \mathrm{~mA} \mathrm{~g}^{-1}$, respectively.

Hierarchically well-developed porous graphene nanofibers comprising $\mathrm{N}$-doped graphitic carbon (NGC)-coated cobalt oxide hollow nanospheres were tested as anodes for high-rate Li-ion batteries [493]. This nanostructured composite delivers a discharge capacity of $823 \mathrm{mAh} \mathrm{g}^{-1}$ after 500 cycles at $3.0 \mathrm{~A} \mathrm{~g}^{-1}$ current density with a low decay rate of $0.092 \%$ per cycle. The rate capability is also noteworthy as the structure exhibits high discharge capacities of 422 and $222 \mathrm{mAh} \mathrm{g}^{-1}$ at current densities of 50 and $100 \mathrm{~A} \mathrm{~g}^{-1}$, respectively. $\mathrm{Co}_{3} \mathrm{O}_{4} / \mathrm{rGO}$ composite powder with the nanobubble-decorated $\mathrm{rGO}$ sphere structure was prepared by spray pyrolysis with a reduction process under a mixture of $\mathrm{H}_{2}$ and $\mathrm{Ar}$ gas (i.e., nanoscale Kirkendall diffusion process [494]. Tested as anode for Li-ion battery at the current density of $2 \mathrm{~A} \mathrm{~g} \mathrm{~g}^{-1}$ for 200 cycles before and after the nanoscale Kirkendall diffusion, the $\mathrm{Co}_{3} \mathrm{O}_{4} / \mathrm{rGO}$ composite powders show discharge capacities of 932 and $1156 \mathrm{mAh} \mathrm{g}^{-1}$, respectively, with capacity retention of $89 \%$ and $99 \%$, respectively, at the second cycle.

\subsubsection{CoO-Based Composites}

Cobalt monoxide including nanoparticles, nanorods, and mesoporous nanowires have been under prime study because its theoretical capacity of $716 \mathrm{mAh} \mathrm{g}^{-1}$ (following the conversion reaction $\mathrm{CoO}$ $+2 \mathrm{Li}^{+}+2 \mathrm{e}^{-} \leftrightarrow \mathrm{Co}^{0}+\mathrm{Li}_{2} \mathrm{O}$ ) and its long cycling stability when combined with rGO [495]. Fu and coworkers [496] elaborated a series of $\mathrm{CoO} / \mathrm{rGO}$ composites with different proportions via an in-situ hydrothermal method and investigated them as an additive for the nickel-based alkaline secondary battery cathode. The Ni electrode including $5 \mathrm{wt} \%$ of $\mathrm{CoO} / \mathrm{rGO}(5: 5)$ delivered a high discharge capacity $208.6 \mathrm{mAh} \mathrm{g}^{-1}$ at $10 \mathrm{C}$ rate.

Bindumadhavan et al. [497] fabricated a cobalt oxide decorated reduced graphene oxide ( $\mathrm{CoO} / \mathrm{rGO})$ nanocomposites prepared by simultaneous reduction of $\mathrm{GO}$ and $\mathrm{Co}^{2+}$ in the presence of $\mathrm{NaBH}_{4}$. The addition of $15 \mathrm{wt} \%$ rGO led to a narrow size distribution of ultra-fine $\mathrm{CoO}$ NPs. For loading ratios of rGO of $5,15,25$, and $35 \mathrm{wt} \%$, the BET specific surface area of $\mathrm{CoO} / \mathrm{rGO}$ increases to 81 , 87,94 and $117 \mathrm{~m}^{2} \mathrm{~g}^{-1}$, respectively. Later, the same group has developed a facile and simple route for the preparation of ultrafine $\mathrm{CoO} / \mathrm{rGO}$ nanohybrids with tunable particle size and crystallinity. The homogeneous and ultrafine CoO NPs ( $4.5 \mathrm{~nm}$ in size) were intimately attached onto rGO surface 
after an optimized calcination time of $60 \mathrm{~min}$ forming $\mathrm{CoO} / \mathrm{rGO}$ flakes $\sim 30 \mathrm{~nm}$ thick. These $\mathrm{CoO} / \mathrm{rGO}$ composite anodes delivered a specific capacity of $520 \mathrm{mAh} \mathrm{g}^{-1}$ at current rate of $2.0 \mathrm{~A} \mathrm{~g}^{-1}$, and the capacity was recovered to $900 \mathrm{mAh} \mathrm{g}^{-1}$ at $150 \mathrm{~mA} \mathrm{~g}^{-1}$ after 60 cycles [498]. The $\mathrm{CoO} / \mathrm{rGO}$ composite developed by Wang et al. [499] was synthesized using a hydrothermal process $\left(160^{\circ} \mathrm{C}, 6 \mathrm{~h}\right)$ of a GO suspension mixed with a $\mathrm{Co}\left(\mathrm{NO}_{3}\right)_{2}$ solution followed by an annealing at $500{ }^{\circ} \mathrm{C}$ for $2 \mathrm{~h}$ under nitrogen ambient. The as-fabricated composite anode exhibited a first discharge capacity of $1312 \mathrm{mAh} \mathrm{g}^{-1}$ at a current density of $100 \mathrm{~mA} \mathrm{~g}^{-1}$. The results of long-term cycling demonstrated a capacity of $557 \mathrm{mAh} \mathrm{g}^{-1}$ at a high current density of $10 \mathrm{~A} \mathrm{~g}^{-1}$ after 300 cycles.

The CoO-based composite anode proposed by Sun et al. [500] was composed of $\mathrm{CoO}-\mathrm{Co}_{3} \mathrm{O}_{4}$ heterostructure nanoribbons $(\sim 50 \mathrm{~nm})$ sandwiched between rGO nanosheets through a solvothermal technique and a sintering process at $350{ }^{\circ} \mathrm{C}$ in $\mathrm{N}_{2}$ atmosphere for $1 \mathrm{~h}$. The $\mathrm{CoO}-\mathrm{Co}_{3} \mathrm{O}_{4} / \mathrm{rGO}$ composite with a specific surface area of $150 \mathrm{~m}^{2} \mathrm{~g}^{-1}$ and average pore size of $4.2 \mathrm{~nm}$ delivered a reversible capacity of $994 \mathrm{mAh} \mathrm{g}^{-1}$ at a current density of $100 \mathrm{~mA} \mathrm{~g}^{-1}$ after 200 cycles and presented good cyclability of $395 \mathrm{mAh} \mathrm{g}^{-1}$ after 500 cycles even at a high charge-discharge rate of $1 \mathrm{~A} \mathrm{~g}^{-1}$. The rate capability of the $\mathrm{CoO}-\mathrm{Co}_{3} \mathrm{O}_{4} / \mathrm{rGO}$ anode carried out at 100, 200, 500, 1000, 2000, 5000, and $100 \mathrm{~mA} \mathrm{~g}^{-1}$ after each 10 cycles at each current density was 1210, 1060, 890, 730, 578, 392, and $915 \mathrm{mAh} \mathrm{g}^{-1}$, respectively. Cao et al. [501] assembled a CoO/rGO hybrid for LIBs by using oleic acid as particle shape controller. The composite with $19 . \mathrm{wt} \%$ carbon had a BET specific surface area of $183.6 \mathrm{~m}^{2} \mathrm{~g}^{-1}$ and pore size in the range $5-10 \mathrm{~nm}$. It delivered a highest capacity of $1309 \mathrm{mAh} \mathrm{g}^{-1}$ after 100 cycles at $0.1 \mathrm{~A} \mathrm{~g}^{-1}$ current rate. The diffusion coefficient of $\mathrm{Li}$ ions in the $\mathrm{CoO} / \mathrm{rGO}$ network determined from EIS measurements was $4.37 \times 10^{-15} \mathrm{~cm}^{2} \mathrm{~s}^{-1}$ (Figure 15).
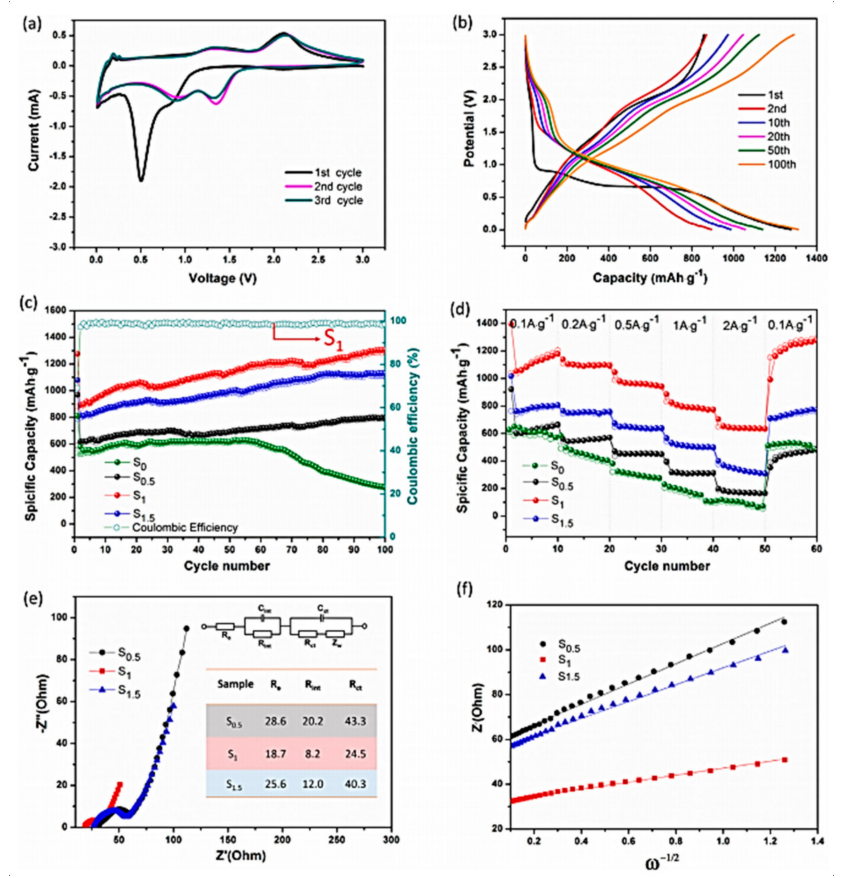

Figure 15. Electrochemical analysis of $\mathrm{Co} / \mathrm{rGO}$ composites synthesized via hydrothermal route using oleic acid (OA) as particle shape controller (samples are marked as $S_{x}$, where $x(0,0.5,1,1.5)$ represented the content of $\mathrm{OA}$ in the precursor materials). (a) The first three CV curves of S1 electrode at a scan rate of $0.1 \mathrm{mV} \cdot \mathrm{s}^{-1}$ from $0.005 \mathrm{~V}$ to $3 \mathrm{~V}$. (b) The galvanostatic charge/discharge (GCD) profiles of S1-based anode cycled between 0.005 and $3 \mathrm{~V}$ at a current of $0.1 \mathrm{~A} \cdot \mathrm{g}^{-1}$. (c) Cycling performance of S0, S0.5, S1, S1.5 electrodes and corresponding coulombic efficiency of S1 electrode at a specific current of $0.1 \mathrm{~A} \cdot \mathrm{g}^{-1}$. (d) Rate capability of S0, S0.5, S1, and S1.5 electrodes. (e) Nyquist plots of S0.5, S1, and S1.5 electrodes after 10 cycles. (Inset is the equivalent circuit model used to simulate the spectra and the corresponding impedance parameters). (f) The relationship between $Z^{\prime}$ and $\omega^{-1 / 2}$ at low frequencies for S0.5, S1, and S1.5 electrodes. Reproduced with permission from [501]. Copyright 2018 Elsevier. 
Leng et al. [502] reported the synthesis of $\mathrm{rGO} / \mathrm{CoO}$ nanowires (diameter of 10-20 $\mathrm{nm}$ and length of several $\mu \mathrm{m}$ ) mutually supporting porous structure using an in situ method by annealing self-assembled $\mathrm{GO} / \mathrm{Co}\left(\mathrm{CO}_{3}\right)_{0.5}(\mathrm{OH}) \cdot 0.11 \mathrm{H}_{2} \mathrm{O}$ nanowires in $\mathrm{N}_{2}$ environment. The as-prepared $\mathrm{CoO} / \mathrm{rGO}$ anode material (BET specific surface area of $66.1 \mathrm{~m}^{2} \mathrm{~g}^{-1}$ ) presented a high reversible capacity of $994 \mathrm{mAh} \mathrm{g}^{-1}$ even after 100 cycles with $96.3 \%$ capacity retention of the first discharge capacity, and superior rate capability $\left(262 \mathrm{mAh} \mathrm{g}^{-1} 10 \mathrm{~A} \mathrm{~g}^{-1}\right)$. This electrode sustained a capacity of $520 \mathrm{mAh} \mathrm{g}^{-1}$ at a current rate of $3 \mathrm{~A} \mathrm{~g}^{-1}$ after 750 cycles. More recently, Yin et al. [503] designed a new $\mathrm{CoO} / \mathrm{Co}_{2} \mathrm{~B} / \mathrm{rGO}$ nanocomposite anode with large capacitive contribution for high-efficiency and durable lithium storage. The composite was synthesized by a combination of precipitation method and pyrolysis. Initial discharge/charge capacities of $889 / 669 \mathrm{mAh} \mathrm{g}^{-1}$ with a high ICE of $75.28 \%$ at $0.1 \mathrm{C}$ rate are delivered for the $\mathrm{CoO} / \mathrm{Co}_{2} \mathrm{~B} / \mathrm{rGO}$ composite with primary particles of 20-60 $\mathrm{nm}$. The proportion of the capacitive contribution deduced from cyclic voltammetry is calculated to be $89.2 \%$. Table 11 summarizes the electrochemical performance of $\mathrm{CoO} / \mathrm{rGO}$ composites as anodes for LIBs from the recent literature.

Table 11. Electrochemical performance of $\mathrm{Co} / \mathrm{rGO}$ composite anode materials. Relevant cycle number is given in brackets.

\begin{tabular}{|c|c|c|c|c|}
\hline Material & Synthesis & $\begin{array}{l}\text { Specific Capacity } \\
\left(m A h \mathrm{~g}^{-1}\right)\end{array}$ & $\begin{array}{l}\text { Current Density } \\
\left(\mathrm{mA} \mathrm{g}^{-1}\right)\end{array}$ & Ref. \\
\hline Co hollow cube/rGO & sacrificial-template + annealing & 1170 & $150(60)$ & [504] \\
\hline m-CoO NRs/rGO & hydrothermal + calcination & 960 & $100(50)$ & [505] \\
\hline $\mathrm{CoO} / 3 \mathrm{D}$ rGO hydrogel & hydrothermal + calcination & 962 & $200(80)$ & [506] \\
\hline $\mathrm{Co} / \mathrm{rGO}$ & simultaneous reduction & 690 & $600(60)$ & [497] \\
\hline $\mathrm{CoO} / \mathrm{rGO}$ flakes & simultaneous reduction & 900 & $150(60)$ & [498] \\
\hline $\mathrm{CoO}-\mathrm{Co}_{3} \mathrm{O}_{4} / \mathrm{rGO}$ & solvothermal + sintering & 994 & $100(200)$ & [500] \\
\hline $\mathrm{CoO} / \mathrm{Co}_{2} \mathrm{~B} / \mathrm{rGO}$ & precipitation + pyrolysis & 276 & $10 \mathrm{C}$ & [503] \\
\hline $\mathrm{CoO} / \mathrm{rGO}$ & one-pot in situ solution & 577 & $100(435)$ & [507] \\
\hline $\mathrm{CoO} / \mathrm{CuO} / \mathrm{rGO}$ & hydrothermal & 1364 & $200(100)$ & [508] \\
\hline $\mathrm{CoO} / \mathrm{rGO}$ & hydrothermal + calcination & 557 & $10000(300)$ & [499] \\
\hline $\mathrm{CoO} / \mathrm{rGO}$ & hydrothermal (oleic acid) & 1039 & $100(100)$ & [501] \\
\hline $\mathrm{CoO} / \mathrm{rGO}$ NWs & in situ self-assembly & 520 & $3000(750)$ & [502] \\
\hline
\end{tabular}

\subsection{Copper-Based Oxide Composites}

Song et al. [509] manufactured a three-dimensional $\mathrm{CuO} / \mathrm{GO}$ aerogel cylindrical composite as a super-capacitor electrode material through a one-step self-assembly hydrothermal procedure at $180^{\circ} \mathrm{C}$ for $8 \mathrm{~h}$ using $\mathrm{Cu}\left(\mathrm{NO}_{3}\right)_{2}$ as $\mathrm{Cu}$ precursor and citric acid as reducing agent. The as-prepared product exhibited specific capacitance of $211 \mathrm{~F} \mathrm{~g}^{-1}$ at current density of $1 \mathrm{~A} \mathrm{~g}^{-1}$. Liu et al. [510] reported the synthesis of sponge-like porous $\mathrm{GO} / \mathrm{CNTs} / \mathrm{CuO}$ hybrid aerogel as anode material for lithium-ion batteries. The samples were prepared as a flocculent suspension obtained by adding a GO suspension and oxidized water-soluble CNTs treated with nitric acid in a $\mathrm{CuO}$ colloidal solution followed by a hydrothermal reduction at $180^{\circ} \mathrm{C}$ for $10 \mathrm{~h}$. The galvanostatic charge-discharge tests carried out in the voltage range of $0.01-3.0 \mathrm{~V}$ under a constant current density of $67 \mathrm{~mA} \mathrm{~g}^{-1}(0.1 \mathrm{C})$ demonstrated the excellent cyclic retention of the binder-free $\mathrm{GO} / \mathrm{CNTs} / \mathrm{CuO}$ hybrid with the specific capacity of $636.9 \mathrm{mAh} \mathrm{g}^{-1}$ after 80 cycles. Zhu and coworkers [511] designed three-dimensional CuO/PANI/rGO ternary hierarchical architectures (where PANI is polyaniline) using an in-situ polymerization method combined with hydrothermal route at $180^{\circ} \mathrm{C}$ for $12 \mathrm{~h}$. The $\mathrm{CuO} / \mathrm{PANI} / \mathrm{rGO}$ hybrid was reversibly cycled as electrode for supercapacitor in a high voltage region up to $1.2 \mathrm{~V}$ with $97.4 \%$ specific capacitance retention after 10,000 cycles. It exhibited a maximum specific capacitance of $634 \mathrm{~F} \mathrm{~g}^{-1}$ and a high energy density of $126.8 \mathrm{Wh} \mathrm{kg}^{-1}$ with a power density of $114.2 \mathrm{~kW} \mathrm{~kg}^{-1}$ at a current density of $1.0 \mathrm{~A} \mathrm{~g}^{-1}$. Zhao et al. [512] reported the synthesis of $\mathrm{CuO} / \mathrm{GO}$ composites in the water-N,N-dimethylformamide without an extra reducing agent, which provided mesoporous sample with high BET surface area of $235 \mathrm{~m}^{2} \mathrm{~g}^{-1}$. Zhu et al. [513] reported the synthesis of $\mathrm{CuO} / \mathrm{GO}$ hybrids by aligning $\mathrm{CuO}$ nanoparticles onto GO sheets in the water-isopropanol media. The authors suggested that the formation mechanism of these $\mathrm{CuO} / \mathrm{GO}$ nanocomposites occurred as intercalation and adsorption of $\mathrm{Cu}^{2+}$ ions onto the $\mathrm{GO}$ 
sheets, followed by the nucleation and growth of the $\mathrm{CuO}$ crystallites. The $\mathrm{CuO} / \mathrm{rGO}$ nanocomposite anode was prepared via microwave-assisted method within short reaction times $(<20 \mathrm{~min})$ and subsequent sintering at $500{ }^{\circ} \mathrm{C}$ for $5 \mathrm{~h}$ by Rai et al. [514]. The first discharge capacity of the nanocomposite (40-65 nm particle size and specific surface area of $37.7 \mathrm{~m}^{2} \mathrm{~g}^{-1}$ ) with $10 \mathrm{wt} \%$ graphene was reported at $1043 \mathrm{mAh} \mathrm{g}^{-1}$ with reversible capacity retention of $516 \mathrm{mAh} \mathrm{g}^{-1}$ after 45 cycles at $0.1 \mathrm{~mA} \mathrm{~cm}^{-2}$ over the potential range of $0.01-3.0 \mathrm{~V} \mathrm{vs} \mathrm{Li}^{+} / \mathrm{Li}$. These results compared well with the theoretical specific capacity of $670 \mathrm{mAh} \mathrm{g}^{-1}$ based on the electrode conversion reaction, i.e., $\mathrm{CuO}+$ $2 \mathrm{Li}^{+}+2 \mathrm{e}^{-} \leftrightarrow \mathrm{Cu}^{0}+\mathrm{Li}_{2} \mathrm{O}$. Xu and coworkers [515] reported the fabrication of core-shell structured $\mathrm{Cu}_{2} \mathrm{O} @ \mathrm{GO}$ composite consisting of $\mathrm{Cu}_{2} \mathrm{O}$ microspheres encapsulated by $\mathrm{GO}$ nanosheets. These anode materials delivered a reversible capacity of $458 \mathrm{mAh} \mathrm{g}^{-1}$ at a current density of $100 \mathrm{~mA} \mathrm{~g}^{-1}$ after 50 cycles and a reversible capacity of $240 \mathrm{mAh} \mathrm{g}^{-1}$ after 200 cycles even at a high charge-discharge rate cycling of $1 \mathrm{~A} \mathrm{~g} \mathrm{~g}^{-1}$. The rate capability evaluated by the ratio of capacity at $100 / 1000 \mathrm{~mA} \mathrm{~g}^{-1}$ was $49 \%$ for the $\mathrm{Cu}_{2} \mathrm{O} @ \mathrm{GO}$ hybrid, against $25 \%$ for a bare $\mathrm{Cu}_{2} \mathrm{O}$ anode.

In 2016, Sun et al. [516] reported the synthesis of $\mathrm{Cu}_{2} \mathrm{O}-\mathrm{CuO}-\mathrm{RGO}$ composites as anode materials by a self-assembly solvothermal method in a water-ethanol mixture, which delivered a reversible capacity of $842 \mathrm{mAh} \mathrm{g}^{-1}$ after 80 cycles at a current density of $100 \mathrm{~mA} \mathrm{~g}^{-1}$. The capacity measured every 10 cycles at current densities of 100, 200, 500, 1000, 2000, 5000, and $100 \mathrm{~mA} \mathrm{~g}^{-1}$ were 840, 723, 511, 402, 336,224 , and $703 \mathrm{mAh} \mathrm{g}^{-1}$, respectively. These greatly improved electrochemical behaviors are closely related to the sandwich-like and mesoporous structure of the composite, which had a high specific surface area of $132.1 \mathrm{~m}^{2} \mathrm{~g}^{-1}$ and typical pore sizes in a wide range (2.5-20 nm). Sheikhzadeh et al. [517] fabricated nanocomposite foam layer of $\mathrm{CuO} / \mathrm{GO}$ by the deposition of $\mathrm{GO}$ particles on electroplated $\mathrm{CuO}$ foam layers through electrophoretic deposition providing samples with BET surface area of $99.2 \mathrm{~m}^{2} \mathrm{~g}^{-1}$ and average pore diameter of $29 \mathrm{~nm}$. By embedding GO particles on $\mathrm{CuO}$ during $7 \mathrm{~min}$, a specific capacitance of $334 \mathrm{~F} \mathrm{~g}^{-1}$ was obtained. A 3D Ni-Cu foam/rGO composite was prepared by the electrochemical deposition of rGO nanosheets on Ni-Cu foam ( 0 to $-1.5 \mathrm{~V}$ vs. SCD) and the subsequent reduction by cyclic voltammetry under different sweep rates in the range of $10-100 \mathrm{mV} \mathrm{s}^{-1}$ [518]. The Ni-Cu foam/rGO hybrid deposited electrochemically at the sweep rate of $50 \mathrm{mV} \mathrm{s}^{-1}$ presented the specific capacitance of $1380 \mathrm{~F} \mathrm{~g}^{-1}$ at a discharge rate of $2 \mathrm{~A} \mathrm{~g}^{-1}$ and an energy density of $30 \mathrm{Wh} \mathrm{kg}^{-1}$ at a power density of $10.2 \mathrm{~kW} \mathrm{~kg}^{-1}$.

\subsection{Nickel-Based Oxide Composites}

Nickel monoxide has received widespread attention because of its high theoretical specific capacity of $718 \mathrm{mAh} \mathrm{g}^{-1}$ for $2 \mathrm{Li}^{+}$uptake from the conversion reaction $\mathrm{NiO}+2 \mathrm{Li}^{+}+2 \mathrm{e}^{-} \leftrightarrow \mathrm{Ni}^{0}+$ $\mathrm{Li}_{2} \mathrm{O}$. In addition, it is a low-cost, safe, and environmentally friendly compound. Several synthesis techniques are used to fabricated $\mathrm{NiO} / \mathrm{rGO}$ composites including hydrothermal method [519], thermal decomposition [520], solvothermal [521], in situ ultrasonic agitation [522,523], and heterogeneous assembly approach with subsequent in-situ thermal reduction [524].

Liu et al. reported the formation of hierarchical $\mathrm{NiO} / \mathrm{rGO}$ nanohybrids with tunable microstructures through the thermal decomposition of $\mathrm{Ni}(\mathrm{OH})_{2} / \mathrm{rGO}$ formed by the electrostatic attraction between exfoliated $\mathrm{Ni}(\mathrm{OH})_{2}$ and GO nanosheets [520]. Ren et al. [525] reported the hydrothermal synthesis and lithium storage performance of binary $\mathrm{NiO} \mathrm{NWs} / \mathrm{rGO}$ and ternary $\mathrm{NiO} / \mathrm{rGO} / \mathrm{PPy}$ hybrids as anode materials for LIBs. The ternary composite was prepared by chemical oxidation polymerization of pyrrole monomer with a template of the binary hybrid. The $\mathrm{NiO} / \mathrm{rGO} / \mathrm{PPy}$ hybrid delivered the first discharge capacity of $1080 \mathrm{mAh} \mathrm{g}^{-1}$ at $0.2 \mathrm{C}$ rate and the first charge capacity reached $830 \mathrm{mAh} \mathrm{g}^{-1}$. After 40 cycles, the discharge capacity is maintained at $499 \mathrm{mAh} \mathrm{g}^{-1}$. Li et coworkers [519] designed a hybrid $\mathrm{NiO} / \mathrm{rGO}$ structure with flower-like $\mathrm{NiO}$ wrapped homogeneously by $\mathrm{rGO}$ sheets via a facile and controllable hydrothermal treatment of the suspension formed with $\mathrm{Ni}\left(\mathrm{NO}_{3}\right)_{2} \cdot 6 \mathrm{H}_{2} \mathrm{O}$, $\mathrm{CO}\left(\mathrm{NH}_{2}\right)_{2}, \mathrm{NH}_{4} \mathrm{~F}$, and GO and subsequent annealing at $400^{\circ} \mathrm{C}$ for $2 \mathrm{~h}$ in $\mathrm{Ar}$ ambient. The NiO/RGO nanocomposites exhibited a reversible specific capacity of $702 \mathrm{mAh} \mathrm{g}^{-1}$ after 100 cycles at a current density of $100 \mathrm{~mA} \mathrm{~g}^{-1}$. NiO-ZnO/rGO composites with $\mathrm{NiO}-\mathrm{ZnO}$ nanoflakes were obtained by 
thermal annealing of sonically mixed $\mathrm{Ni}(\mathrm{OH})_{2}-\mathrm{Zn}(\mathrm{OH})_{2} / \mathrm{rGO}$ precursor [526]. The as-prepared porous anode material, which exhibited a specific surface area of $110.49 \mathrm{~m}^{2} \mathrm{~g}^{-1}$ and pore size distribution in the range $30-80 \mathrm{~nm}$, delivered a reversible capacity of $1017 \mathrm{mAh} \mathrm{g}^{-1}$ at a current density of $100 \mathrm{~mA} \mathrm{~g}^{-1}$ after 200 cycles and a specific capacity of $458 \mathrm{mAh} \mathrm{g}^{-1}$ at $500 \mathrm{~mA} \mathrm{~g}^{-1}$ even after 400 cycles. A specific capacity of $185 \mathrm{mAh} \mathrm{g}^{-1}$ was reached at a current density of $2000 \mathrm{~mA} \mathrm{~g}^{-1}$ (Figure 16). The double-layer $\mathrm{NiFe}_{2} \mathrm{O}_{4} @ \mathrm{NiO}$-hollow-nanosphere (mean size of $14 \mathrm{~nm}$ ) decorated rGO composite was prepared by spray pyrolysis with nanoscale Kirkendall diffusion. The first discharge capacities of the nanosphere-decorated $\mathrm{rGO}$ composite powders with filled $\mathrm{NiFe}_{2} \mathrm{O}_{4} / \mathrm{NiO}$ and hollow $\mathrm{NiFe}_{2} \mathrm{O}_{4} @ \mathrm{NiO}$, at a current density of $1 \mathrm{~A} \mathrm{~g}^{-1}$, are 1168 and $1319 \mathrm{mAh} \mathrm{g}^{-1}$, respectively, which decrease to 597 and $951 \mathrm{mAh} \mathrm{g}^{-1}$, respectively, after 100 cycles. For repeated lithium-ion discharge at the high current density of $4 \mathrm{~A} \mathrm{~g}^{-1}$ for the 400 th cycle, a capacity of $789 \mathrm{~mA} \mathrm{~h} \mathrm{~g}^{-1}$ is delivered by the $\mathrm{NiFe}_{2} \mathrm{O}_{4} @ \mathrm{NiO} / \mathrm{rGO}$ hybrid [527].
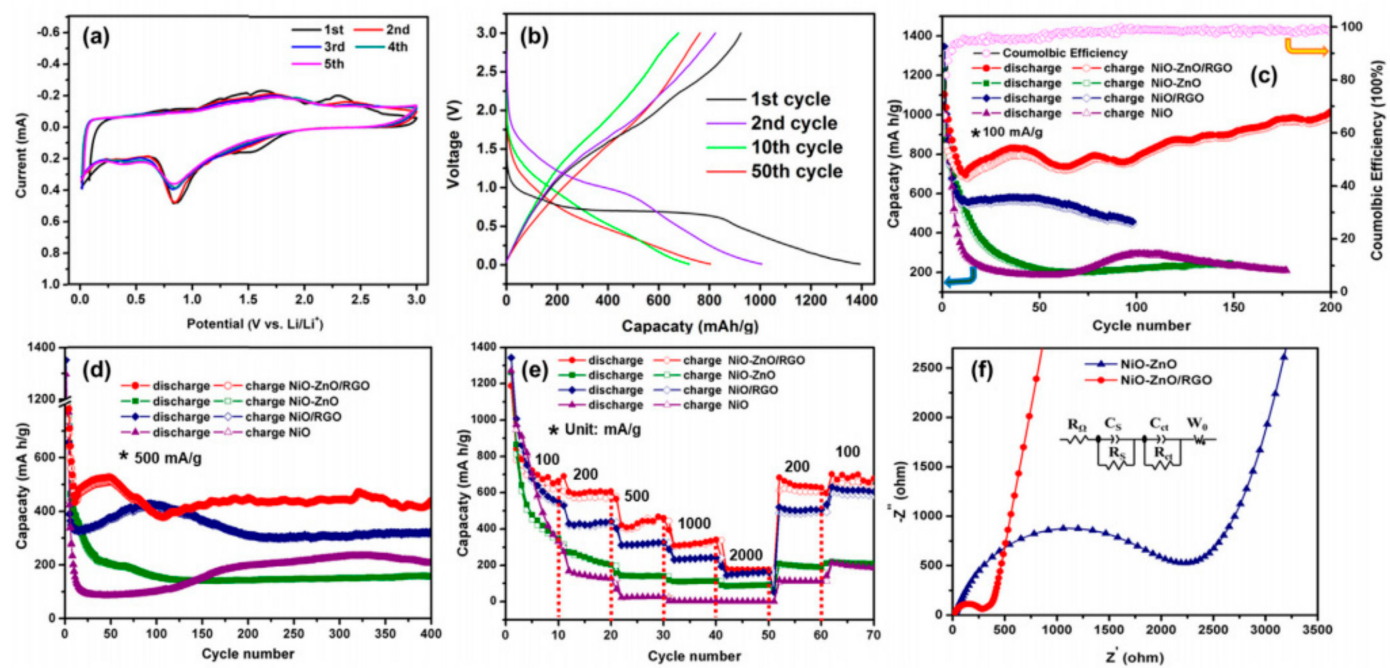

Figure 16. Electrochemical analysis of the NiO-ZnO/RGO composite. (a) CV curves at a scan rate of $0.1 \mathrm{mV} \mathrm{s}^{-1}$. (b) GCD profiles at a current density of $100 \mathrm{~mA} \mathrm{~g}^{-1}$. (c,d) Comparison of cycling performance of $\mathrm{NiO}, \mathrm{NiO} / \mathrm{ZnO}, \mathrm{NiO} / \mathrm{RGO}$, and $\mathrm{NiO}-\mathrm{ZnO} / \mathrm{RGO}$ composite at current densities of 100 and $500 \mathrm{~mA} \mathrm{~g}^{-1}$, respectively. (e) Rate capability of the four samples at various current densities. (f) Nyquist plots of $\mathrm{NiO}-\mathrm{ZnO}$ and $\mathrm{NiO}-\mathrm{ZnO} / \mathrm{RGO}$ fresh electrodes at $3.0 \mathrm{~V} \mathrm{vs}$. $\mathrm{Li}^{+} / \mathrm{Li}$. Reproduced with permission from [526]. Copyright 2018 Elsevier.

Recently, Tian et al. [521] used metal organic frameworks as $\mathrm{NiO}$ precursor for the fabrication of $\mathrm{NiO} / \mathrm{rGO}$ anode, which provided a modest specific capacity of $440 \mathrm{mAh} \mathrm{g}^{-1}$ at $1 \mathrm{C}$ rate after 200 cycles. In situ ultrasonic agitation method followed by heat calcination in $\mathrm{N}_{2}$ atmosphere was carried out for the synthesis of $\mathrm{NiO}$ nanoflakes/rGO hybrid, which delivered reversible capacity of $825 \mathrm{mAh} \mathrm{g} \mathrm{g}^{-1}$ after 50 cycles at $100 \mathrm{~mA} \mathrm{~g}^{-1}$, higher than that of the pure $\mathrm{NiO}$ flakes $\left(197 \mathrm{mAh} \mathrm{g}^{-1}\right)$ [518]. Ma and coworkers [523] studied the lithium storage properties of $\mathrm{NiO} / \mathrm{rGO}$ composites derived from different degrees of GO through an ultrasonic agitation technique. The reversible capacity of these anode materials increased gradually to $1046 \mathrm{mAh} \mathrm{g}^{-1}$ and then declined to $956 \mathrm{mAh} \mathrm{g}^{-1}$ after 50 cycles at $100 \mathrm{~mA} \mathrm{~g}^{-1}$ current rate. Another Ni-based complex with spinel structure was optimized by $\mathrm{Li}$ et al. [528], namely the $\mathrm{NiFe}_{2} \mathrm{O}_{4} / \mathrm{rGO}$ composite, which was fabricated via a hydrothermal-annealing procedure. The $\mathrm{NiFe}_{2} \mathrm{O}_{4} / \mathrm{rGO}$ with $\mathrm{NiFe}_{2} \mathrm{O}_{4}$ nanoparticles $20 \mathrm{~nm}$ diameter retained a specific capacity of $1105 \mathrm{mAh} \mathrm{g}^{-1}$ at a current density of $100 \mathrm{~mA} \mathrm{~g}^{-1}$ over 50 cycles.

\section{Anode Materials for Na-Ion Batteries}

To obtain anodes with high performances, it is important to exploit the entire graphene layer-which provides favorable sites for energy storage - and to construct the overall conductivity of 
the graphene networks. In this regard, CNTs can bridge the vertical defects for electron transfer in the graphene layers and increase the distance between graphene sheets. Therefore, when CNTs and graphene are combined with transition-metal chalcogenides (TMCs), synergistic effects on the anodes are expected by the bridging graphene and the suppression of the restacking of graphene sheets during repeated charge and discharge processes. Golden bristlegrass-like unique nanostructures comprising rGO matrixed nanofibers entangled with bamboo-like N-doped CNTs containing CoSe ${ }_{2}$ nanocrystals at each node (N-CNT/rGO/CoSe 2 ) are designed as anodes for high-rate sodium-ion batteries (SIBs). During a simple etching process, the defects in the N-CNTs allow the complete phase conversion of Co into $\mathrm{CoSe}_{2}$ through the efficient penetration of $\mathrm{H}_{2}$ Se gas inside the $\mathrm{CNT}$ walls. The N-CNT/rGO/CoSe 2 hybrid, tested as anode material for sodium-ion batteries (SIBs), delivers a discharge capacity of $264 \mathrm{mAh} \mathrm{g}^{-1}$ after 10,000 cycles at a high current density of $10 \mathrm{~A} \mathrm{~g}^{-1}$, and the capacity retention of $89 \%$ at the 100th cycle. The rate capability tests show discharge capacities of 395, 263, and $151 \mathrm{mAh} \mathrm{g}^{-1}$ at 1 , 10, and $20 \mathrm{~A} \mathrm{~g}^{-1}$ current densities, respectively [529].

Mesoporous $\mathrm{WSe}_{2} / \mathrm{rGO}$ composites as anode materials for SIBs were prepared by spray pyrolysis and subsequent selenization. The composite particles exhibit both well-dispersed rGO nanosheets and well-faceted $\mathrm{WSe}_{2}$ nanocrystals with plenty of folded edges. The $\mathrm{WSe}_{2} / \mathrm{rGO}$ composite and bare $\mathrm{WSe}_{2}$ deliver discharge capacities of the 238 and $36 \mathrm{mAh} \mathrm{g}^{-1}$, respectively, for the 100th cycle at a current density of $0.5 \mathrm{~A} \mathrm{~g}^{-1}$. The $\mathrm{WSe}_{2} / \mathrm{rGO}$ composite shows much lower onset potential and larger current density $\left(36.5 \mathrm{~mA} \mathrm{~cm}^{-2}\right.$ at $\left.\eta=300 \mathrm{mV}\right)$ than those of the bare WSe 2 particles $\left(0.61 \mathrm{~mA} \mathrm{~cm}^{-2}\right.$ at $\left.\eta=300 \mathrm{mV}\right)$ [530]. Through the treatment of $\mathrm{Fe}_{3} \mathrm{O}_{4} / \mathrm{rGO}$ powders under $\mathrm{H}_{2} \mathrm{Te}$ gas, the $\mathrm{FeTe}_{2} / \mathrm{rGO}$ hybrid powders were prepared via spray pyrolysis. Electrochemically tested as the anode materials for sodium-ion batteries (SIBs), the $\mathrm{FeTe}_{2} / \mathrm{rGO}$ composite containing $5 \mathrm{wt} \%$ rGO delivered discharge capacities of 493 and $293 \mathrm{mAh} \mathrm{g}^{-1}$ for the 1st and 80th cycles, respectively. The Na-ion storage mechanism for $\mathrm{FeTe}_{2}$ in SIBs is described by $\mathrm{FeTe}_{2}+4 \mathrm{Na}^{+}+4 \mathrm{e}^{-} \leftrightarrow \mathrm{Fe}+2 \mathrm{Na}_{2} \mathrm{Te}$ (i.e., the discharge process forms metallic Fe nanocrystals and $\mathrm{Na}_{2} \mathrm{Te}$ by a conversion reaction) [531]. Hybrid of graphene-wrapped $\mathrm{NiSe}_{2} / \mathrm{C}$ porous nanofibers $\left(\mathrm{NiSe}_{2} / \mathrm{rGO}-\mathrm{C}\right.$ ) were prepared via electrospinning and a subsequent selenization process with optimum amount of amorphous carbon obtained from the polystyrene to polyacrylonitrile ratio of 1:4. The electrochemical tests in sodium cell at a current density of $200 \mathrm{~mA} \mathrm{~g}^{-1}$ show initial discharge capacities of the NiSe 2 -rGO-C composite (nanofibers of $27 \mathrm{~nm}$ ) and bare $\mathrm{NiSe}_{2}$ nanofibers of 717 and $755 \mathrm{mAh} \mathrm{g}^{-1}$, respectively, which decrease to 468 and $35 \mathrm{mAh} \mathrm{g}^{-1}$ after 100 cycles [532]. A 1D nanohybrid comprised of conductive graphitic carbon (GC)-coated hollow $\mathrm{FeSe}_{2}$ nanospheres decorating reduced graphene oxide (rGO) nanofiber (FeSe $\left.{ }_{2} @ G C-r G O\right)$ was designed as an efficient anode material for SIBs [533]. The hollow nanosphere $\mathrm{FeSe}_{2} @$ GC-rGO hybrid nanofibers deliver a discharge capacity of $412 \mathrm{mAh} \mathrm{g}^{-1}$ at a current density

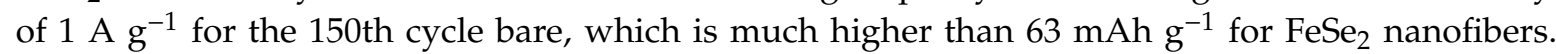
Even at high current density of $10 \mathrm{~A} \mathrm{~g}^{-1}$, a discharge capacity of $352 \mathrm{mAh} \mathrm{g}^{-1}$ was achieved, which arose from the synergetic effects of the $\mathrm{FeSe}_{2}$ hollow morphology and highly conductive rGO matrix. $\mathrm{FeSe}_{\mathrm{x}} / \mathrm{rGO}$ composite, in which hollow $\mathrm{FeSe}_{\mathrm{x}}$ nanoparticles are uniformly distributed throughout the rGO matrix, was prepared by spray pyrolysis applying the nanoscale Kirkendall diffusion process. The powders had mixed crystal structures of FeSe and $\mathrm{FeSe}_{2}$ phases. The $\mathrm{FeSe}_{\mathrm{x}} / \mathrm{rGO}$ composite has superior sodium-ion storage properties compared to those of the $\mathrm{Fe}_{2} \mathrm{O}_{3} / \mathrm{rGO}$ hybrid with similar morphological characteristics. The discharge capacities of the $\mathrm{FeSe}_{\mathrm{x}} / \mathrm{rGO}$ and $\mathrm{Fe}_{2} \mathrm{O}_{3} / \mathrm{rGO}$ composites deliver discharge capacities of 434 and $174 \mathrm{mAh} \mathrm{g}^{-1}$, respectively, after 200 cycles at $0.3 \mathrm{~A} \mathrm{~g}^{-1}$ current rate. The $\mathrm{FeSe}_{\mathrm{x}} / \mathrm{rGO}$ hybrid had a high discharge capacity of $311 \mathrm{mAh} \mathrm{g}^{-1}$ for the 1000 th cycle at a high current density of $1 \mathrm{~A} \mathrm{~g}^{-1}$ [534].

\section{Concluding Remarks}

In this review, attention was focused on advanced anode composite materials showing efforts currently made towards the technological development of nanostructured electrodes. For the sake of 
comparison and discussion, the best electrochemical properties obtained with the components have been reported. The advantages and disadvantages of a series of anode materials are highlighted.

The constant progress experienced these last five years evidenced here demonstrates that the rGO-based composites are good candidates as anode materials for rechargeable batteries providing high specific capacity that allows high energy density. They compete with the conventional graphite anodes in terms of rate capability, cycle ability, and safety. Owing to their very good mechanical properties in addition to their good electrical conductivity, remarkable improvement of the electrochemical properties of the anodes are observed with amounts of rGO as small as $1-5 \mathrm{wt} \%$. For mobile applications, such as batteries for EVs, and for static utilization, to buffer the intermittence problem and integration of the production of wind and solar plants to the grid energy storage, the rGO-based hybrids are efficient to improve the structural stability of the electrochemically active materials.

The choice of rGO instead of graphene, which exhibits superior electrical conductivity, is guided by its great hydrophylic behavior and easy deposition on any surface with any method. The simple and fast preparation of rGO by reduction of GO suggest its low-cost and scalable production. Chemical reduction of GO can be eco-friendly achieved using reducing mild agents derived from natural fruits or vegetables. In addition, the oxygen functionalities anchored on the surface of rGO render ability to functionalize graphene with desirable properties and engineer them into diverse morphologies. In contrast, the preparation of graphene without defects is not trivial and is costly in terms of mass production (one needs a CVD system and carbon precursor gases (i.e., $\mathrm{CH}_{4}$ ). Actually, mass production remains a bottleneck for the production of high-quality graphene derivatives. The reduction of GO to rGO is thus considered as the most promising route for mass production in the near future, sustained by many applications, not only in the framework of energy storage, but also for biosensors, organic solar cells, actuators, and touch panels [535]. In addition, the performance of Si@graphene and Si @rGO anodes reported in this review for comparison do not evidence a clear advantage to graphene. Interestingly, a more detailed comparison between graphene and rGO-based nanoplatforms on electrochromic switching kinetics show that improved electrochromic switching kinetics is observed on reduced graphene oxide in comparison to the pristine graphene sheets, possibly due to the more heterogeneous electron transfer in graphene [536]. This phenomenon might also explain the remarkable results obtained with rGO-supported materials as anodes for the LIBs.

Owing to their excellent electrochemical performance, composites formed with a single element (silicon, germanium, tin) or with metal oxides $\mathrm{MO}_{\mathrm{x}}$ with $M=\mathrm{Si}, \mathrm{Ti}, \mathrm{Mo}, \mathrm{Mn}, \mathrm{Co}, \mathrm{Ni}, \mathrm{Cu}$, etc., have been the most studied hybrid anodes, which can deliver high specific capacity (at least twice the graphite value of $372 \mathrm{mAh} \mathrm{g}^{-1}$ ). However, anode materials that are electrochemically active by conversion reaction suffered for a long time from the huge variation of volume during cycling. The superior performance of composite in batteries originates from the addition of reduced graphene oxide and their architecture (i.e., from 1D to 3D), which boost the reaction kinetics and electrode stability. The introduction of rGO facilitates the continuous and rapid electron transport and prevent the collapse of nanostructures and aggregation of the active materials. In addition, the strategies adopted in the design of nanocomposites are effective methods to mitigate the large volume changes and low electrical conductivities often met in the bare anodes.

Herewith, we have given many examples according to which such electrodes are better performing. For each composite, we have identified, as possible as it was, the electrochemical properties in relation with its morphology (i.e., particle size, specific surface area, porosity, etc.). Alloying materials such as $\mathrm{Si}, \mathrm{Ge}, \mathrm{SiO}_{\mathrm{x}}$, and $\mathrm{SnO}_{2}$ and compounds based on conversion reaction $\mathrm{MO}_{\mathrm{x}}$ can provide much larger capacities, and energy densities than the Ti-O oxides based on insertion reaction (i.e., $\mathrm{TiO}_{2}$, $\mathrm{Li}_{3} \mathrm{TiO}_{4}, \mathrm{Li}_{4} \mathrm{Ti}_{5} \mathrm{O}_{12}$ ). Si, $\mathrm{SnO}_{2}$, and $\mathrm{Mn}$-based oxides are the most promising elements of this family, while germanium is expensive and not abundant in nature. The big challenge of such nanostructured composite anodes is now the cost, and a scalable production. With the composites of rGO with metal oxides being presently prepared only at the laboratory scale, hopefully the recent results suggest that the one-pot in-situ hydrothermal process is a viable method for the large-scale production for battery 
electrodes. Today, this technology has the capability to fabricate many composites, which can deliver a capacity superior to $500 \mathrm{mAh} \mathrm{g}^{-1}$ and even more for thousands of cycles. Therefore, the rGO holds great promise for use as composite element in electrode for advanced rechargeable batteries such as lithium-sulfur batteries, lithium-air batteries, aluminum-ion batteries, etc. Undoubtedly, the future of rGO-based composites as anode materials for energy storage devices remains very promising and exciting.

Author Contributions: Conceptualization, C.M.J. and S.S.I.; investigation, P.S., A.A.; writing-original draft preparation, C.M.J.; writing—review and editing, A.M. All authors have read and agreed to the published version of the manuscript.

Funding: This research received no external funding.

Conflicts of Interest: The authors declare no conflict of interest.

\section{References}

1. Zaghib, K.; Mauger, A.; Julien, C. Rechargeable lithium batteries for energy storage in smart grids. Recharg. Lithium Batter. 2015, 81, 319-351.

2. Mauger, A.; Armand, M.; Julien, C.M.; Zaghib, K. Challenges and issues facing lithium metal for solid-state rechargeable batteries. J. Power Sources 2017, 353, 333-342. [CrossRef]

3. Reddy, M.V.; Rao, G.V.S.; Chowdari, B.V.R. Metal oxides and oxysalts as anode materials for Li ion batteries. Chem. Rev. 2013, 113, 5364-5457. [CrossRef] [PubMed]

4. Ji, L.; Lin, Z.; Alcoutlabi, M.; Zhang, X. Recent developments in nanostructured anode materials for rechargeable lithium-ion batteries. Energy Environ. Sci. 2011, 4, 2682-2699. [CrossRef]

5. Zhang, W.-J. A review of the electrochemical performance of alloy anodes for lithium-ion batteries. J. Power Sources 2011, 196, 13-24. [CrossRef]

6. Goriparti, S.; Miele, E.; De Angelis, F.; Di Fabrizio, E.; Zaccaria, R.P.; Capiglia, C. Review on recent progress of nanostructured anode materials for Li-ion batteries. J. Power Sources 2014, 257, 421-443. [CrossRef]

7. Hassoun, J.; Scrosati, B. Review-Advances in anode and electrolyte materials for the progress of lithium-ion and beyond lithium-ion batteries. J. Electrochem. Soc. 2015, 162, A2582-A2588. [CrossRef]

8. Lu, J.; Chen, Z.; Pan, F.; Cui, Y.; Amine, K. High-performance anode materials for rechargeable lithium-ion batteries. Electrochem. Energy Rev. 2018, 1, 35-53. [CrossRef]

9. Yang, S.; Feng, X.; Ivanovici, S.; Müllen, K. Fabrication of graphene-encapsulated oxide nanoparticles: Towards high-performance anode materials for lithium storage. Angew. Chem. Int. Ed. 2010, 49, 8408-8411. [CrossRef]

10. Sun, W.; Wang, Y. Graphene-based nanocomposite anodes for lithium-ion batteries. Nanoscale 2014, 6, 11528-11552. [CrossRef]

11. Mauger, A.; Xie, H.; Julien, C.M. Composite anodes for lithium-ion batteries: Status and trends. AIMS Mater. Sci. 2016, 3, 1054-1106. [CrossRef]

12. Novoselov, K.S.; Geim, A.K.; Morozov, S.V.; Jiang, D.; Zhang, Y.; Dubonos, S.V.; Grigorieva, I.V.; Firsov, A.A. Electric field effect in atomically thin carbon films. Science 2004, 306, 666-669. [CrossRef]

13. Geim, A.K.; Novoselov, K.S. The rise of graphene. Nat. Mater. 2007, 6, 183-191. [CrossRef] [PubMed]

14. Lee, C.; Wei, X.; Kysar, J.W.; Hone, J. Measurement of the elastic properties and intrinsic strength of monolayer graphene. Science 2008, 321, 385-388. [CrossRef]

15. Mahmood, N.; Zhang, C.; Yin, H.; Hou, Y. Graphene-based nanocomposites for energy storage and conversion in lithium batteries, supercapacitors and fuel cells. J. Mater. Chem. A 2014, 2, 15-32. [CrossRef]

16. Han, S.; Wang, J.; Li, S.; Wu, D.; Feng, X. Graphene aerogel supported $\mathrm{Fe}_{5}\left(\mathrm{PO}_{4}\right)_{4}(\mathrm{OH})_{3} \cdot 2 \mathrm{H}_{2} \mathrm{O}$ microspheres as high performance cathode for lithium ion batteries. J. Mater. Chem. A 2014, 2, 6174. [CrossRef]

17. Li, F.; Jiang, X.; Zhao, J.; Zhang, S. Graphene oxide: A promising nanomaterial for energy and environmental applications. Nano Energy 2015, 16, 488-515. [CrossRef]

18. Zhu, J.; Yang, D.; Yin, Z.; Yan, Q.; Zhang, H. Graphene and graphene-based materials for energy storage applications. Small 2014, 10, 3480-3498. [CrossRef] 
19. Javed, K.; Oolo, M.; Savest, N.; Krumme, A. A review on graphene-based electrospun conductive nanofibers, supercapacitors, anodes and cathodes for lithium-ion batteries. Crit. Rev. Solid State Mater. Sci. 2019, 44, 427-443. [CrossRef]

20. Chen, D.; Feng, H.; Li, J. Graphene oxide: Preparation, functionalization and electrochemical applications. Chem. Rev. 2012, 112, 6027-6053. [CrossRef]

21. Kuila, T.; Mishra, A.K.; Khanra, P.; Kim, N.H.; Lee, J.H. Recent advances in the efficient reduction of graphene oxide and its application as energy storage electrode materials. Nanoscale 2012, 5, 52-71. [CrossRef] [PubMed]

22. Li, K.; Shua, F.; Guo, X.; Xue, D. High performance porous MnO@C composite anode materials for lithium-ion batteries. Electrochim. Acta 2016, 188, 793-800. [CrossRef]

23. Gao, F.; Qin, S.-H.; Zang, Y.-H.; Gu, J.-F.; Qu, J. Highly efficient formation of $\mathrm{Mn}_{3} \mathrm{O}_{4}$-graphene oxide hybrid aerogels for use as the cathode material of high performance lithium ion batteries. New Carbon Mater. 2020, 35, 121-130. [CrossRef]

24. Wang, X.; Zhou, X.; Yao, K.; Zhang, J.; Liu, Z. A SnO 2 /graphene composite as a high stability electrode for lithium ion batteries. Carbon 2011, 49, 133-139. [CrossRef]

25. Deng, Y.; Fang, C.; Chen, G. The developments of $\mathrm{SnO}_{2} /$ graphene nanocomposites as anode materials for high performance lithium ion batteries: A review. J. Power Sources 2016, 304, 81-101. [CrossRef]

26. Sun, Y.; Hu, X.; Luo, W.; Huang, Y. Self-assembled hierarchical $\mathrm{MoO}_{2}$ /graphene nanoarchitectures and their application as a high-performance anode material for lithium-ion batteries. ACS Nano 2011, 5, 7100-7107. [CrossRef] [PubMed]

27. Sennu, P.; Kim, H.S.; An, J.Y.; Aravindan, V.; Lee, Y.-S. Synthesis of 2D/2D structured mesoporous $\mathrm{Co}_{3} \mathrm{O}_{4}$ nanosheet/N-doped reduced graphene oxide composites as a highly stable negative electrode for lithium battery applications. Chem. Asian J. 2015, 10, 1776-1783. [CrossRef]

28. Li, X.; Huang, X.; Liu, D.; Wang, X.; Song, S.; Zhou, L.; Zhang, H. Synthesis of 3D hierarchical Fe ${ }_{3} \mathrm{O}_{4} /$ graphene composites with high lithium storage capacity and for controlled drug delivery. J. Phys. Chem. C 2011, 115, 21567-21573. [CrossRef]

29. Wang, R.; Xu, C.; Du, M.; Sun, J.; Gao, L.; Zhang, P.; Yao, H.; Lin, C. Solvothermal-induced self-assembly of $\mathrm{Fe}_{2} \mathrm{O}_{3} / \mathrm{GS}$ aerogels for high Li-storage and excellent stability. Small 2014, 10, 2260-2269. [CrossRef]

30. Wu, P.; Wang, H.; Tanga, Y.; Zhou, Y.; Lu, T. Three-dimensional interconnected network of graphene-wrapped porous silicon spheres: In situ magnesiothermic-reduction synthesis and enhanced lithium-storage capabilities. ACS Appl. Mater. Interfaces 2014, 6, 3546-3552. [CrossRef]

31. Ren, J.-G.; Wu, Q.-H.; Tang, H.; Hong, G.; Zhang, W.; Lee, S.-T. Germanium-graphene composite anode for high-energy lithium batteries with long cycle life. J. Mater. Chem. A 2012, 1, 1821-1826. [CrossRef]

32. Chockla, A.M.; Panthani, M.G.; Holmberg, V.C.; Hessel, C.M.; Reid, D.K.; Bogart, T.D.; Harris, J.T.; Mullins, C.B.; Korgel, B.A. Electrochemical lithiation of graphene-supported silicon and germanium for rechargeable batteries. J. Phys. Chem. C 2012, 116, 11917-11923. [CrossRef]

33. Yue, W.; Yang, S.; Liu, Y.; Yang, X. A facile synthesis of mesoporous graphene-tin composites as high-performance anodes for lithium-ion batteries. Mater. Res. Bull. 2013, 48, 1575-1580. [CrossRef]

34. Wu, Z.-S.; Zhou, G.; Yin, L.-C.; Ren, W.; Li, F.; Cheng, H.-M. Graphene/metal oxide composite electrode materials for energy storage. Nano Energy 2012, 1, 107-131. [CrossRef]

35. Jana, A.; Scheer, E.; Polarz, S. Synthesis of graphene-transition metal oxide hybrid nanoparticles and their application in various fields. Beilstein J. Nanotechnol. 2017, 8, 688-714. [CrossRef]

36. Ke, Q.; Wang, J. Graphene-based materials for supercapacitor electrodes-A review. J. Materiomics 2016, 2, 37-54. [CrossRef]

37. Chee, W.K.; Lim, H.N.; Zainal, Z.; Huang, N.M.; Harrison, I.; Andou, Y. Flexible graphene-based supercapacitors: A review. J. Phys. Chem. C 2016, 120, 4153-4172. [CrossRef]

38. Park, S.; Ruoff, R.S. Chemical methods for the production of graphenes. Nat. Nanotechnol. 2009, 4, $217-224$. [CrossRef]

39. Brodie, B.C. Sur le poids atomique du graphite. Ann. Chem. Phys. 1860, 59, 466-472.

40. Becerril, H.A.; Mao, J.; Liu, Z.; Stoltenberg, R.M.; Bao, Z.; Chen, Y. Evaluation of solution-processed reduced graphene oxide films as transparent conductors. ACS Nano 2008, 2, 463-470. [CrossRef]

41. Hummers, W.S.; Offeman, R.E. Preparation of graphitic oxide. J. Am. Chem. Soc. 1958, 80, 1339. [CrossRef] 
42. Qiu, X.; Liu, Y.; Wang, L.; Fan, L.-Z. Reverse microemulsion synthesis of nickel-cobalt hexacyanoferrate/ reduced graphene oxide nanocomposites for high-performance supercapacitors and sodium ion batteries. Appl. Surf. Sci. 2018, 434, 1285-1292. [CrossRef]

43. Wang, M.-S.; Song, W.-L.; Fan, L.-Z. Three-dimensional interconnected network of graphene-wrapped silicon/carbon nanofiber hybrids for binder-free anodes in lithium-ion batteries. ChemElectroChem 2015, 2, 1699-1706. [CrossRef]

44. Si, Y.; Samulski, E.T. Synthesis of water soluble graphene. Nano Lett. 2008, 8, 1679-1682. [CrossRef]

45. Rao, S.; Upadhyay, J.; Polychronopoulou, K.; Umer, R.; Das, R. Reduced graphene oxide: Effect of reduction on electrical conductivity. J. Compos. Sci. 2018, 2, 25. [CrossRef]

46. Wang, H.; Tian, H.-W.; Wang, X.-W.; Qiao, L.; Wang, S.-M.; Wang, X.-L.; Zheng, W.-T.; Liu, Y.-C. Electrical conductivity of alkaline-reduced graphene oxide. Chem. Res. Chinese Univ. 2011, 27, 857-861.

47. Tokarczyk, M.; Kowalski, G.; Witowski, A.; Kozinski, R.; Librant, K.; Aksienionek, M.; Lipińska, L.; Ciepielewski, P. Structural and electronic properties of graphene oxide and reduced graphene oxide papers prepared by high pressure and high temperature treatment. Acta Phys. Pol. A 2014, 126, 1190-1194. [CrossRef]

48. Marquez, C.; Rodríguez, N.; Ruiz, R.; Gamiz, F. Electrical characterization and conductivity optimization of laser reduced graphene oxide on insulator using point-contact methods. RSC Adv. 2016, 6, 46231-46237. [CrossRef]

49. Shabir, A.; Sehrawat, P.; Julien, C.M.; Islam, S.S. Reversible synthesis of GO: Role of differential bond structure transformation in fine-tuning photodetector response. Nanotechnology 2020, 32, 045601. [CrossRef]

50. Pei, S.; Cheng, H.-M. The reduction of graphene oxide. Carbon 2012, 50, 3210-3228. [CrossRef]

51. Dikin, D.A.; Stankovich, S.; Zimney, E.J.; Piner, R.D.; Dommett, G.H.B.; Evmenenko, G.; Nguyen, S.T.; Ruoff, R.S. Preparation and characterization of graphene oxide paper. Nat. Cell Biol. 2007, 448, 457-460. [CrossRef] [PubMed]

52. Chua, C.K.; Pumera, M. Reduction of graphene oxide with substituted borohydrides. J. Mater. Chem. A 2012, 1, 1892-1898. [CrossRef]

53. Liu, Y.; Zhang, Y.; Ma, G.; Wang, Z.; Liu, K.; Liu, H. Ethylene glycol reduced graphene oxide/polypyrrole composite for supercapacitor. Electrochim. Acta 2013, 88, 519-525. [CrossRef]

54. Zhang, J.; Yang, H.; Shen, G.; Cheng, P.; Zhang, J.; Guo, S. Reduction of graphene oxide via L-ascorbic acid. Chem. Commun. 2010, 46, 1112-1114. [CrossRef] [PubMed]

55. Fan, Z.; Wang, K.; Wei, T.; Yan, J.; Song, L.; Shao, B. An environmentally friendly and efficient route for the reduction of graphene oxide by aluminum powder. Carbon 2010, 48, 1686-1689. [CrossRef]

56. Maddineni, S.B.; Mandal, B.K. Biofabrication of reduction of graphene oxide nanosheets using terminalia Bellirica fruit extract. Current Nanosci. 2016, 12, 94-102. [CrossRef]

57. Yang, J.; Wang, Y.; Wang, J.; Chan-Park, M.B. Reducing graphene oxide with a modified Birch reaction. RSC Adv. 2015, 5, 11124-11127. [CrossRef]

58. Li, B.; Cao, H.; Shao, J.; Qu, M. Enhanced anode performances of the $\mathrm{Fe}_{3} \mathrm{O}_{4}$-carbon-rGO three dimensional composite in lithium ion batteries. Chem. Commun. 2011, 47, 10374-10376. [CrossRef]

59. Mei, L.; Xu, C.; Yang, T.; Ma, J.; Chen, L.; Li, Q.; Wang, T. Superior electrochemical performance of ultrasmall $\mathrm{SnS}_{2}$ nanocrystals decorated on flexible RGO in lithium-ion batteries. J. Mater. Chem. A 2013, 1, 8658-8664. [CrossRef]

60. Patil, S.B.; Nagaraju, G.; Kishore, B.; Nagaraju, G.; Dupont, J.; Nagaraju, G. High capacity $\mathrm{MoO}_{3} / \mathrm{rGO}$ nanocomposite anode for lithium ion batteries: An intuition into the conversion mechanism of $\mathrm{MoO}_{3}$. New J. Chem. 2018, 42, 18569-18577. [CrossRef]

61. Paek, S.-M.; Yoo, E.; Honma, I. Enhanced cyclic performance and lithium storage capacity of $\mathrm{SnO}_{2} /$ graphene nanoporous electrodes with three-dimensionally delaminated flexible structure. Nano Lett. 2009, 9, 72-75. [CrossRef] [PubMed]

62. Zhou, G.; Wang, D.-W.; Li, F.; Zhang, L.; Li, N.; Wu, Z.-S.; Wen, L.; Lu, G.Q. (Max); Cheng, H.-M. Graphene-wrapped $\mathrm{Fe}_{3} \mathrm{O}_{4}$ anode material with improved reversible capacity and cyclic stability for lithium ion batteries. Chem. Mater. 2010, 22, 5306-5313. [CrossRef]

63. Мa, C.; Xu, J.; Alvarado, J.; Qu, B.; Somerville, J.; Lee, J.Y.; Meng, Y.S. Investigating the energy storage mechanism of $\mathrm{SnS}_{2}$-rGO composite anode for advanced Na-ion batteries. Chem. Mater. 2015, 27, 5633-5640. [CrossRef] 
64. Zhang, Q.; Karthick, R.; Zhao, X.; Zhang, L.-G.; Shi, Y.; Sun, L.; Su, C.-Y.; Chen, F. Sb nanoparticle decorated rGO as a new anode material in aqueous chloride ion batteries. Nanoscale 2020, 12, 12268-12274. [CrossRef]

65. Zensich, M.; Jaumann, T.; Morales, G.M.; Giebeler, L.; Barbero, C.; Balach, J. A top-down approach to build $\mathrm{Li}_{2} \mathrm{~S} @$ rGO cathode composites for high-loading lithium-sulfur batteries in carbonate-based electrolyte. Electrochim. Acta 2018, 296, 243-250. [CrossRef]

66. Abalonyx. Available online: https://www.abalonyx.no/?cat=42023. (accessed on 17 September 2020).

67. Kimiagar, S.; Rashidi, N.; Ghadim, E.E. Investigation of the effects of temperature and time on reduction of graphene oxide by microwave hydrothermal reactor. Bull. Mater. Sci. 2015, 38, 1699-1704. [CrossRef]

68. Pimenta, M.A.; Dresselhaus, G.; Dresselhaus, M.S.; Cançado, L.G.; Jorio, A.; Saito, R. Studying disorder in graphite-based systems by Raman spectroscopy. Phys. Chem. Chem. Phys. 2007, 9, 1276-1290. [CrossRef]

69. Tian, L.; Zhuang, Q.; Yueli, S.; Shigang, S.; Chen, J.; Lu, F.; Sun, S. Mechanism of intercalation and deintercalation of lithium ions in graphene nanosheets. Chin. Sci. Bull. 2011, 56, 3204-3212. [CrossRef]

70. Datta, D.; Li, J.; Koratkar, N.; Shenoy, V.B. Enhanced lithiation in defective graphene. Carbon 2014, 80, 305-310. [CrossRef]

71. Lin, K.-H.; Kuo, C.-L. Lithiation mechanisms and lithium storage capacity of reduced graphene oxide nanoribbons: A first-principles study. J. Mater. Chem. A 2017, 5, 4912-4922. [CrossRef]

72. Pan, D.; Wang, S.; Zhao, B.; Wu, M.; Zhang, H.; Wang, Y.; Jiao, Z. Li Storage properties of disordered graphene nanosheets. Chem. Mater. 2009, 21, 3136-3142. [CrossRef]

73. Robledo, C.; Otero, M.; Luque, G.L.; Camara, O.; Barraco, D.; Rojas, M.; Leiva, E. First-principles studies of lithium storage in reduced graphite oxide. Electrochim. Acta 2014, 140, 232-237. [CrossRef]

74. Randviir, E.P.; Banks, C.E. Graphene and Graphene Oxide for Energy Storage; Wiley: Hoboken, NJ, USA, 2017; pp. 725-744.

75. Kühne, M. Lithium Intercalation in Bilayer Graphene Devices; Springer Science and Business Media LLC: Berlin/Heidelberg, Germany, 2018; pp. 1-92.

76. Matsuo, Y.; Sasaki, T.; Maruyama, S.; Inamoto, J.; Okamoto, Y.; Tamura, N. Electrochemical intercalation behaviors of lithium ions into graphene-like graphite. J. Electrochem. Soc. 2018, 165, A2409-A2414. [CrossRef]

77. Ji, K.; Han, J.; Hirata, A.; Fujita, T.; Shen, Y.; Ning, S.; Liu, P.; Kashani, H.; Tian, Y.; Ito, Y.; et al. Lithium intercalation into bilayer graphene. Nat. Commun. 2019, 10,1-10. [CrossRef]

78. Kheirabadi, N.; Shafiekhani, A. Graphene/Li-ion battery. J. Appl. Phys. 2012, 112, 124323. [CrossRef]

79. Wang, C.; Li, D.; Too, C.O.; Wallace, G.G. Electrochemical properties of graphene paper electrodes used in lithium batteries. Chem. Mater. 2009, 21, 2604-2606. [CrossRef]

80. Gedela, V.; Puttapati, S.K.; Nagavolu, C.; Srikanth, V.V.S.S. A unique solar radiation exfoliated reduced graphene oxide/polyaniline nanofibers composite electrode material for supercapacitors. Mater. Lett. 2015, 152, 177-180. [CrossRef]

81. Puttapati, S.K.; Gedela, V.; Srikanth, V.V.S.S.; Reddy, M.V.; Adams, S.; Chowdari, B.V.R. Unique reduced graphene oxide as efficient anode material in Li ion battery. Bull. Mater. Sci. 2018, 41, 53. [CrossRef]

82. Kim, H.; Seo, D.-H.; Kim, S.-W.; Kim, J.; Kang, K. Highly reversible $\mathrm{Co}_{3} \mathrm{O}_{4}$ /graphene hybrid anode for lithium rechargeable batteries. Carbon 2011, 49, 326-332. [CrossRef]

83. Li, B.; Cao, H.; Shao, J.; Li, G.; Qu, M.; Yin, G. $\mathrm{Co}_{3} \mathrm{O}_{4} @$ graphene Composites as Anode Materials for High-Performance Lithium Ion Batteries. Inorg. Chem. 2011, 50, 1628-1632. [CrossRef]

84. Zhang, F.; Yang, X.; Xie, Y.; Yi, N.; Huang, Y.; Chen, Y. Pyrolytic carbon-coated Si nanoparticles on elastic graphene framework as anode materials for high-performance lithium-ion batteries. Carbon 2015, 82, 161-167. [CrossRef]

85. Ji, J.; Ji, H.; Zhang, L.L.; Zhao, X.; Bai, X.; Fan, X.; Zhang, F.; Ruoff, R.S. Graphene-encapsulated Si on ultrathin-graphite foam as anode for high capacity lithium-ion batteries. Adv. Mater. 2013, 25, 4673-4677. [CrossRef] [PubMed]

86. Lin, N.; Zhou, J.; Zhu, Y.; Qian, Y. Embedding silicon nanoparticles in graphene based 3D framework by cross-linking reaction for high performance lithium ion batteries. J. Mater. Chem. A 2014, 2, 19604-19608. [CrossRef]

87. Chang, J.; Huang, X.; Zhou, G.; Cui, S.; Mao, S.; Chen, J. Three-dimensional carbon-coated Si/rGO nanostructures anchored by nickel foam with carbon nanotubes for Li-ion battery applications. Nano Energy 2015, 15, 679-687. [CrossRef] 
88. Wang, B.; Li, X.; Zhang, X.; Luo, B.; Jin, M.; Liang, M.; Dayeh, S.A.; Picraux, S.T.; Zhi, L. Adaptable silicon-carbon nanocables sandwiched between reduced graphene oxide sheets as lithium ion battery anodes. ACS Nano 2013, 7, 1437-1445. [CrossRef] [PubMed]

89. Cao, H.; Li, B.; Zhang, J.; Lian, F.; Kong, X.; Qu, M. Synthesis and superior anode performance of TiO ${ }_{2} @$ reduced graphene oxide nanocomposites for lithium ion batteries. J. Mater. Chem. 2012, 22, 9759-9766. [CrossRef]

90. Ji, L.; Zheng, H.; Ismach, A.; Tan, Z.; Xun, S.; Lin, E.; Battaglia, V.; Srinivasan, V.; Zhang, Y. Graphene/Si multilayer structure anodes for advanced half and full lithium-ion cells. Nano Energy 2012, 1, 164-171. [CrossRef]

91. De Guzman, R.C.; Yang, J.; Cheng, M.M.-C.; Salley, S.O.; Ng, K.Y.S. Effects of graphene and carbon coating modifications on electrochemical performance of silicon nanoparticle/graphene composite anode. J. Power Sources 2014, 246, 335-345. [CrossRef]

92. Wong, D.P.; Tseng, H.-P.; Chen, Y.-T.; Hwang, B.-J.; Chen, L.-C.; Chen, K.-H. A stable silicon/graphene composite using solvent exchange method as anode material for lithium ion batteries. Carbon 2013, 63, 397-403. [CrossRef]

93. Xiang, H.; Zhang, K.; Ji, G.; Lee, J.Y.; Zou, C.; Chen, X.; Wu, J. Graphene/nanosized silicon composites for lithium battery anodes with improved cycling stability. Carbon 2011, 49, 1787-1796. [CrossRef]

94. Lee, J.K.; Smith, K.B.; Hayner, C.M.; Kung, H.H. Silicon nanoparticles-graphene paper composites for Li ion battery anodes. Chem. Commun. 2010, 46, 2025-2027. [CrossRef]

95. Julien, C.M.; Mauger, A.; Vijh, A.; Zaghib, K. Lithium Batteries: Science and Technology; Springer: Cham, Switzerland, 2016; pp. 323-429.

96. Chou, S.-L.; Wang, J.-Z.; Choucair, M.; Liu, H.-K.; Stride, J.A.; Dou, S.-X. Enhanced reversible lithium storage in a nanosize silicon/graphene composite. Electrochem. Commun. 2010, 12, 303-306. [CrossRef]

97. Liu, X.; Zhu, X.; Pan, D. Solutions for the problems of silicon-carbon anode materials for lithium-ion batteries. R. Soc. Open Sci. 2018, 5, 172370. [CrossRef] [PubMed]

98. Jamaluddin, A.; Umesh, B.; Chen, F.; Chang, J.-K.; Su, C.-Y. Facile synthesis of core-shell structured Si@graphene balls as a high-performance anode for lithium-ion batteries. Nanoscale 2020, 12, 9616-9627. [CrossRef] [PubMed]

99. Han, X.; Zhang, Z.; Chen, H.; Qiao-Bao, Z.; Chen, S.; Yang, Y. On the interface design of Si and multilayer graphene for a high-performance Li-ion battery anode. ACS Appl. Mater. Interfaces 2020, 12, 44840-44849. [CrossRef] [PubMed]

100. Huang, Y.; Peng, J.; Luo, J.; Li, W.; Wu, Z.; Shi, M.; Li, X.; Li, N.; Chang, B.; Wang, X.; et al. Spherical $\mathrm{Gr} / \mathrm{Si} / \mathrm{GO} / \mathrm{C}$ composite as high-performance anode material for lithium-ion batteries. Energy Fuels 2020, 34, 7639-7647. [CrossRef]

101. Kim, D.; Luo, Y.; Tiwari, A.P.; Hwang, H.M.; Oh, S.; Lee, K.; Lee, H. Highly stable multi-layered silicon-intercalated graphene anodes for lithium-ion batteries. MRS Commun. 2020, 10, 25-31. [CrossRef]

102. Park, S.-H.; Kim, H.-K.; Ahn, D.-J.; Lee, S.-I.; Roh, K.C.; Kim, K.-B. Self-assembly of Si entrapped graphene architecture for high-performance Li-ion batteries. Electrochem. Commun. 2013, 34, 117-120. [CrossRef]

103. Ye, Y.-S.; Xie, X.; Rick, J.; Chang, F.-C.; Hwang, B.-J. Improved anode materials for lithium-ion batteries comprise non-covalently bonded graphene and silicon nanoparticles. J. Power Sources 2014, 247, 991-998. [CrossRef]

104. Li, Q.; Chen, D.; Li, K.; Wang, J.; Zhao, J. Electrostatic self-assembly bmSi@C/rGO composite as anode material for lithium ion battery. Electrochim. Acta 2016, 202, 140-146. [CrossRef]

105. Liu, L.; Li, X.; Zhang, G.; Zhang, Z.; Fang, C.; Ma, H.; Luo, W.; Liu, Z. Enhanced stability lithium-ion battery based on optimized graphene/Si nanocomposites by templated assembly. ACS Omega 2019, 4, 18195-18202. [CrossRef] [PubMed]

106. Reddy, A.L.M.; Srivastava, A.; Gowda, S.R.; Gullapalli, H.; Dubey, M.; Ajayan, P.M. Synthesis of nitrogen-doped graphene films for lithium battery application. ACS Nano 2010, 4, 6337-6342. [CrossRef] [PubMed]

107. Chang, J.; Huang, X.; Zhou, G.; Cui, S.; Hallac, P.B.; Jiang, J.; Hurley, P.T.; Chen, J. Multilayered Si nanoparticle/reduced graphene oxide hybrid as a high-performance lithium-ion battery anode. Adv. Mater. 2013, 26, 758-764. [CrossRef] [PubMed]

108. Lin, N.; Zhou, J.; Wang, L.; Zhu, Y.; Qian, Y. Polyaniline-assisted synthesis of Si@C/RGO as anode material for rechargeable lithium-ion batteries. ACS Appl. Mater. Interfaces 2014, 7, 409-414. [CrossRef] 
109. Wang, S.; Liao, J.; Wu, M.; Xu, Z.; Gong, F.; Chen, C.; Wang, Y.; Yan, X. High rate and long cycle life of a $\mathrm{CNT} / \mathrm{rGO} / \mathrm{Si}$ nanoparticle composite anode for lithium-ion batteries. Part. Part. Syst. Charact. 2017, 34, 1700141. [CrossRef]

110. Kumar, K.T.; Reddy, M.J.K.; Sundari, G.S.; Raghu, S.; Kalaivani, R.; Ryu, S.H.; Shanmugharaj, A. Synthesis of graphene-siloxene nanosheet based layered composite materials by tuning its interface chemistry: An efficient anode with overwhelming electrochemical performances for lithium-ion batteries. J. Power Sources 2020, 450, 227618. [CrossRef]

111. Dai, J.; Liao, J.; He, M.; Yang, M.; Wu, K.; Yao, W. Si@SnS 2 -reduced graphene oxide composite anodes for high-capacity Li-ion batteries. ChemSusChem 2019, 12, 5092-5098. [CrossRef]

112. Deng, B.; Xu, R.; Wang, X.; An, L.; Zhao, K.; Cheng, G.J. Roll to roll manufacturing of fast charging, mechanically robust $0 \mathrm{D} / 2 \mathrm{D}$ nanolayered Si-graphene anode with well-interfaced and defect engineered structures. Energy Storage Mater. 2019, 22, 450-460. [CrossRef]

113. Bian, F.; Yu, J.; Song, W.; Huang, H.; Liang, C.; Gan, Y.; Xia, Y.; Zhang, J.; He, X.; Zhang, W. A new magnesium hydride route to synthesize morphology-controlled $\mathrm{Si} / \mathrm{rGO}$ nanocomposite towards high-performance lithium storage. Electrochim. Acta 2020, 330, 135248. [CrossRef]

114. Zhaoa, H.; Xuab, X.; Yaoa, Y.; Lic, Y. Si nanoparticles veiled with ultrathin rGO film reduced directly by precoated Ni template: Fabrication and electrochemical performance. Appl. Surf. Sci. 2020, 528, 146993. [CrossRef]

115. Wu, J.; Qin, X.; Zhang, H.; He, Y.-B.; Li, B.; Ke, L.; Lv, W.; Du, H.; Yang, Q.-H.; Kang, F. Multilayred silicon embedded porous carbon/graphene hybrid as a high performance anode. Carbon 2015, 84, 434-443. [CrossRef]

116. Majeed, M.K.; Saleem, A.; Ma, X.; Ma, W. Clay-derived mesoporous Si/rGO for anode material of lithium-ion batteries. J. Alloys Compd. 2020, 848, 156590. [CrossRef]

117. Fang, R.; Xiao, W.; Miao, C.; Mei, P.; Yan, W.; Zhang, Y.; Jiang, Y. Improved lithium storage performance of pomegranate-like Si@NC/rGO composite anodes by facile in-situ nitrogen doped carbon coating and freeze drying processes. J. Alloys Compd. 2020, 834, 155230. [CrossRef]

118. Zhang, K.; Xia, Y.; Yang, Z.; Fu, R.; Shen, C.; Liu, Z. Structure-preserved 3D porous silicon/reduced graphene oxide materials as anodes for Li-ion batteries. RSC Adv. 2017, 7, 24305-24311. [CrossRef]

119. Yu, K.; Zhang, H.; Qi, H.; Liang, J.-C.; Liang, C. High performance of porous silicon/carbon/RGO network derived from rice husks as anodes for lithium-ion batteries. New J. Chem. 2018, 42, 19811-19817. [CrossRef]

120. Chen, S.; Bao, P.; Huang, X.; Sun, B.; Wang, G. Hierarchical 3D mesoporous silicon-graphene nanoarchitectures for lithium ion batteries with superior performance. Nano Res. 2014, 7, 85-94. [CrossRef]

121. Men, X.; Kong, X.; Yang, X.; Wang, B.; Wang, Y.; Liu, Y.; Yu, L.; Li, H.; Xu, B. Synthesis of a pomegranate shaped reduced graphene oxide stabilized secondary $\mathrm{Si}$ nanoparticles composite anode for lithium ion batteries. Int. J. Hydrogen Energy 2020, 45, 29492-29504. [CrossRef]

122. Benzait, Z.; Yuca, N. Synergistic effect of carbon nanomaterials on a cost-effective coral-like Si/rGO composite for lithium ion battery application. Electrochim. Acta 2020, 339, 135917. [CrossRef]

123. Tang, X.; Wen, G.; Zhang, Y.; Wang, D.; Song, Y. Novel silicon nanoparticles with nitrogen-doped carbon shell dispersed in nitrogen-doped graphene and CNTs hybrid electrode for lithium ion battery. Appl. Surf. Sci. 2017, 425, 742-749. [CrossRef]

124. Zhang, Z.; Du, Y.; Li, H. Engineering of a bowl-like Si@rGO architecture for an improved lithium ion battery via synergistic effect. Nanotechnology 2020, 31, 095402. [CrossRef]

125. Chen, Y.; Hu, Y.; Shen, Z.; Chen, R.; He, X.; Zhang, X.; Zhang, Y.; Wu, K. Sandwich structure of graphene-protected silicon/carbon nanofibers for lithium-ion battery anodes. Electrochim. Acta 2016, 210, 53-60. [CrossRef]

126. Pan, Q.; Zuo, P.; Lou, S.; Mu, T.; Du, C.; Cheng, X.; Ma, Y.; Gao, Y.; Yin, G. Micro-sized spherical silicon@carbon@graphene prepared by spray drying as anode material for lithium-ion batteries. J. Alloys Compd. 2017, 723, 434-440. [CrossRef]

127. He, Z.; Wu, X.; Yi, Z.; Wang, X.; Xiang, Y. Silicon/graphene/carbon hierarchical structure nanofibers for high performance lithium ion batteries. Mater. Lett. 2017, 200, 128-131. [CrossRef]

128. Lee, S.-H.; Kim, Y.-J.; Nam, Y.-S.; Park, S.-H.; Lee, H.; Hyun, Y.; Lee, C.-S. Synthesis and characterization of silicon/reduced graphene oxide composites as anodes for Lithium secondary batteries. J. Nanosci. Nanotechnol. 2018, 18, 5026-5032. [CrossRef] [PubMed] 
129. Tao, H.; Xiong, L.; Zhu, S.; Zhang, L.; Yang, X. Porous Si/C/reduced graphene oxide microspheres by spray drying as anode for Li-ion batteries. J. Electroanal. Chem. 2017, 797, 16-22. [CrossRef]

130. Qin, J.; Wu, M.; Feng, T.; Chen, C.; Tu, C.; Li, X.; Duan, C.; Xia, D.; Wang, D. High rate capability and long cycling life of graphene-coated silicon composite anodes for lithium ion batteries. Electrochim. Acta 2017, 256, 259-266. [CrossRef]

131. Pan, Q.; Zhao, J.; Qu, W.; Liu, R.; Li, N.; Xing, B.; Jiang, S.; Pang, M.; Zhao, L.; Zhang, Y.; et al. Facile synthesis of the 3D framework Si@N-doped C/Reduced graphene oxide composite by polymer network method for highly stable lithium storage. J. Phys. Chem. Solids 2019, 133, 92-99. [CrossRef]

132. Toçoğlua, U.; Alaf, M.; Akbulut, H. Towards high cycle stability yolk-shell structured silicon/rGO/MWCNT hybrid composites for Li-ion battery negative electrodes. Mater. Chem. Phys. 2020, 240, 122160. [CrossRef]

133. Xu, H.; Wang, Y.; Chenab, R.; Baiab, Y.; Liab, T.; Jinab, H.; Wanga, J.; Xiaa, H. A green-synthetic spiderweb-like Si@Graphene-oxide anode material with multifunctional citric acid binder for high energy-density Li-ion batteries. Carbon 2020, 157, 330-339. [CrossRef]

134. Wu, Y.-S.; Yang, C.-C.; Wu, S.; Wu, Z.; Wei, C.; Yang, M.; Lue, S.J. Preparation of ternary hierarchical silicon/reduced graphene oxide/carbon composites as anodes for lithium-ion batteries. J. Alloys Compd. 2019, 793, 433-445. [CrossRef]

135. Yu, L.; Liu, J.; He, S.; Huang, C.; Gong, Z.; Gan, L.; Long, M. N-doped rGO/C@Si composites using sustainable chitosan as the carbon source for lithium-ion batteries. Appl. Surf. Sci. 2020, 501, 144136. [CrossRef]

136. Zhu, C.; Zhang, Y.; Ma, Z.; Wang, H.; Sly, G.L. Yolk-void-shell Si-C nano-particles with tunable void size for high-performance anode of lithium ion batteries. Nanotechnology 2020. [CrossRef] [PubMed]

137. Baggetto, L.; Notten, P.H.N. Lithium ion (de)insertion reaction of germanium thin-film electrodes and electrochemical and in-situ XRD study batteries and energy storage. J. Electrochem. Soc. 2009, 156, A169-A175. [CrossRef]

138. Liu, X.; Wu, X.; Chang, B.; Wang, K.-X. Recent progress on germanium-based anodes for lithium ion batteries: Efficient lithiation strategies and mechanisms. Energy Storage Mater. 2020, 30, 146-169. [CrossRef]

139. Liang, W.; Yang, H.; Fan, F.; Liu, Y.; Liu, X.H.; Huang, J.Y.; Zhu, T.; Zhang, S. Tough germanium nanoparticles under electrochemical cycling. ACS Nano 2013, 7, 3427-3433. [CrossRef]

140. Panayotov, V.; Panayotova, M.; Chukharev, S. Recent studies on germanium-nanomaterials for LIBs anodes. E3S Web Conf. 2020, 166, 06012. [CrossRef]

141. Loaiza, L.C.; Montconduit, L.; Seznzc, V. Si and Ge-based anode materials for Li-, Na-, and K-ion batteries: A perspective from structure to electrochemical mechanism. Small 2020, 16, 1905260. [CrossRef]

142. Xue, D.-J.; Xin, S.; Yan, Y.; Jiang, K.-C.; Yin, Y.-X.; Guo, Y.-G.; Wan, L.-J. Improving the electrode performance of Ge through Ge@C core-shell nanoparticles and graphene networks. J. Am. Chem. Soc. 2012, 134, 2512-2515. [CrossRef]

143. Xu, Y.; Zhu, X.; Zhou, X.; Liu, X.; Liu, Y.; Dai, Z.; Bao, J. Ge nanoparticles encapsulated in nitrogen-doped reduced graphene oxide as an advanced anode material for lithium-ion batteries. J. Phys. Chem. C 2014, 118, 28502-28508. [CrossRef]

144. Wang, B.; Wen, Z.; Jin, J.; Hong, X.; Zhang, S.; Rui, K. A novel strategy to prepare Ge@C/rGO hybrids as high-rate anode materials for lithium ion batteries. J. Power Sources 2017, 342, 521-528. [CrossRef]

145. Wang, B.; Jin, J.; Hong, X.; Gu, S.; Guo, J.; Wen, Z. Facile synthesis of the sandwich-structured germanium/reduced graphene oxide hybrid: An advanced anode material for high-performance lithium ion batteries. J. Mater. Chem. A 2017, 5, 13430-13438. [CrossRef]

146. Fang, S.; Shen, L.; Zheng, H.; Zhang, X. Ge-graphene-carbon nanotube composite anode for high performance lithium-ion batteries. J. Mater. Chem. A 2014, 3, 1498-1503. [CrossRef]

147. Chen, Y.; Ma, L.; Shen, X.; Ji, Z.; Yuan, A.; Xu, K.; Shah, S.A. In-situ synthesis of Ge/reduced graphene oxide composites as ultrahigh rate anode for lithium-ion battery. J. Alloys Compd. 2019, 801, 90-98. [CrossRef]

148. Zhao, M.; Zhao, D.-L.; Yang, H.-X.; Han, X.-Y.; Duan, Y.-J.; Tian, X.-M.; Meng, W.-J. Graphene-supported cubic hollow carbon shell-coated germanium particles as high-performance anode for lithium-ion batteries. Ceram. Int. 2019, 45, 13210-13218. [CrossRef]

149. Zhao, F.; Wang, Y.; Zhang, X.; Liang, X.; Zhang, F.; Wang, L.; Li, Y.; Feng, Y.; Feng, W. Few-layer methyl-terminated germanene-graphene nanocomposite with high capacity for stable lithium storage. Carbon 2020, 161, 287-298. [CrossRef] 
150. Meng, W.-J.; Zhao, M.; Yang, H.-X.; Wu, Y.-Q.; Pu, H.; Gao, R.-Z.; Yang, Y.; Zhao, D.-L. Synthesis of $\mathrm{CuGeO} /$ reduced graphene oxide nanocomposite by hydrothermal reduction for high performance $\mathrm{Li}$-ion battery anodes. Ceram. Int. 2020, 46, 9249-9255. [CrossRef]

151. Wen, C.J.; Huggins, R.A. Thermodynamic study of the lithium-tin system. J. Electrochem. Soc. 1981, 128, 1181-1187. [CrossRef]

152. Winter, M.; Besenhard, J.O. Electrochemical lithiation of tin and tin-based intermetallics and composites. Electrochim. Acta 1999, 45, 31-50. [CrossRef]

153. Park, C.-M.; Kim, J.-H.; Kim, H.; Sohn, H.-J. Li-alloy based anode materials for Li secondary batteries. Chem. Soc. Rev. 2010, 39, 3115-3141. [CrossRef]

154. Zhang, P.; Ma, Z.S.; Jiang, W.; Wang, Y.; Pan, Y.; Lu, C. Mechanical properties of Li-Sn alloys for Li-ion battery anodes: A first-principles perspective. AIP Adv. 2016, 6, 015107. [CrossRef]

155. Li, H. Nano-alloy anode for lithium ion batteries. Solid State Ionics 2002, 148, 247-258. [CrossRef]

156. Wang, B.; Luo, B.; Li, X.; Zhi, L. The dimensionality of Sn anodes in Li-ion batteries. Mater. Today 2012, 15, 544-552. [CrossRef]

157. Wang, G.; Wang, B.; Wang, X.; Park, J.; Dou, S.; Ahn, H.; Kim, K. Sn/graphene nanocomposite with 3D architecture for enhanced reversible lithium storage in lithium ion batteries. J. Mater. Chem. 2009, 19, 8378-8384. [CrossRef]

158. Luo, B.; Wang, B.; Liang, M.; Ning, J.; Li, X.; Zhi, L. Reduced graphene oxide-mediated growth of uniform tin-core/carbon-sheath coaxial nanocables with enhanced lithium ion storage properties. Adv. Mater. 2012, 24, 1405-1409. [CrossRef]

159. Wang, H.; Xing, Z.; Hu, Z.; Zhang, Y.; Hu, Y.; Sun, Y.; Ju, Z.; Zhuang, Q. Sn-based submicron-particles encapsulated in porous reduced graphene oxide network: Advanced anodes for high-rate and long life potassium-ion batteries. Appl. Mater. Today 2019, 15, 58-66. [CrossRef]

160. Botas, C.; Carriazo, D.; Singh, G.; Rojo, T. Sn-And $\mathrm{SnO}_{2}-$ graphene flexible foams suitable as binder-free anodes for lithium ion batteries. J. Mater. Chem. A 2015, 3, 13402-13410. [CrossRef]

161. Soler-Piña, F.J.; Hernández-Rentero, C.; Caballero, A.; Morales, J.; Rodríguez-Castellón, E.; Canales-Vázquez, J. Highly graphitized carbon nanosheets with embedded Ni nanocrystals as anode for Li-ion batteries. Nano Res. 2020, 13, 86-94. [CrossRef]

162. Dashairya, L.; Das, D.; Saha, P. Electrophoretic deposition of antimony/reduced graphite oxide hybrid nanostructure: A stable anode for lithium-ion batteries. Mater. Today Commun. 2020, 24, 101189. [CrossRef]

163. Yang, J.; Takeda, Y.; Imanishi, N.; Capiglia, C.; Xie, J.Y.; Yamamoto, O. SiO ${ }_{\mathrm{x}}$-based anodes for secondary lithium batteries. Solid State Ion. 2002, 152-153, 125-129. [CrossRef]

164. Chang, W.-S.; Park, C.-M.; Kim, J.-H.; Kim, Y.-U.; Jeong, G.; Sohn, H.-J. Quartz $\left(\mathrm{SiO}_{2}\right)$ : A new energy storage anode material for Li-ion batteries. Energy Environ. Sci. 2012, 5, 6895-6899. [CrossRef]

165. Yamada, Y.; Iriyama, Y.; Abe, T.; Ogumi, Z. Kinetics of electrochemical insertion and extraction of lithium ion at SiO. J. Electrochem. Soc. 2010, 157, A26. [CrossRef]

166. Xu, X.; Zhang, H.; Chen, Y.; Li, N.; Li, Y.; Liu, L. $\mathrm{SiO}_{2} @ S \mathrm{O}_{2} /$ graphene composite with a coating and hierarchical structure as high performance anode material for lithium ion battery. J. Alloys Compd. 2016, 677, 237-244. [CrossRef]

167. Zhao, Y.; Zheng, L.; Wu, H.; Chen, H.; Su, L.; Wang, L.; Wang, Y.; Ren, $\mathrm{M} . \mathrm{Co}_{2} \mathrm{SiO}_{4} / \mathrm{SiO}_{2} / \mathrm{RGO}$ nanosheets: Boosting the lithium storage capability of tetravalent $\mathrm{Si}$ by using highly-dispersed Co element. Electrochim. Acta 2018, 282, 609-617. [CrossRef]

168. Hu, Z.; Cui, H.; Li, J.; Lei, G.; Li, Z. Constructing three-dimensional Li-transport channels within the $\mathrm{Fe}_{3} \mathrm{O}_{4} @ \mathrm{SiO}_{2} @ \mathrm{RGO}$ composite to improve its electrochemical performance in Li-ion batteries. Ceram. Int. 2020, 46, 18868-18877. [CrossRef]

169. Haeri, S.; Ramezanzadeh, B.; Asghari, M. A novel fabrication of a high performance $\mathrm{SiO}_{2}$-graphene oxide (GO) nanohybrids: Characterization of thermal properties of epoxy nanocomposites filled with $\mathrm{SiO}_{2}-\mathrm{GO}$ nanohybrids. J. Colloid Interface Sci. 2017, 493, 111-122. [CrossRef] [PubMed]

170. Kasimayan, U.; Nadarajan, A.; Singaravelu, C.M.; Pan, G.-T.; Kandasamy, J.; Yang, T.C.-K.; Lin, J.-H. In-situ DRIFT investigation of photocatalytic reduction and oxidation properties of $\mathrm{SiO}_{2} @ \alpha-\mathrm{Fe}_{2} \mathrm{O}_{3}$ core-shell decorated RGO nanocomposite. Sci. Rep. 2020, 10, 1-13. [CrossRef]

171. Zhang, J.; Ma, P.; Hou, Z.; Zhang, X.; Li, C. One-step synthesis of SiO $@$ @graphene composite material by a hydrothermal method lithium-ion batteries anodes. Energy Fuels 2020, 34, 3895-3900. [CrossRef] 
172. Huang, J.; Fam, D.; He, Q.; Chen, H.; Zhan, D.; Faulkner, S.H.; Nimmo, M.; Tok, A.I.Y. The mechanism of graphene oxide as a growth template for complete reduced graphene oxide coverage on an $\mathrm{SiO}_{2}$ substrate. J. Mater. Chem. C 2014, 2, 109-114. [CrossRef]

173. Liang, X.; Liu, S.; Song, X.; Zhu, Y.; Jiang, S. Layer-by-layer self-assembled graphene oxide/silica microsphere composites as stationary phase for high performance liquid chromatography. Analyst 2012, 137, 5237-5244. [CrossRef]

174. Liu, Y.; Zhang, F.R.; Zhu, W.X.; Su, D.; Sang, Z.Y.; Yan, X.; Li, S.; Liang, J.; Dou, S.X. A multifunctional hierarchical porous $\mathrm{SiO}_{2} / \mathrm{GO}$ membrane for high efficiency oil/water separation and dye removal. Carbon 2020, 160, 88-97. [CrossRef]

175. Guo, C.; Wang, D.; Liu, T.; Zhu, J.X.; Lang, X. A three dimensional SiO $/$ /C@RGO nanocomposite as a high energy anode material for lithium-ion batteries. J. Mater. Chem. A 2014, 2, 3521-3527. [CrossRef]

176. Guo, X. Reduced Graphene oxide -coated 3D interconnected $\mathrm{SiO}_{2}$ Nanoparticles with Enhanced Lithium Storage Performance. Int. J. Electrochem. Sci. 2018, 13, 5645-5653. [CrossRef]

177. Chen, L.; Zheng, J.; Lin, S.; Khan, S.; Huang, J.; Liu, S.; Chen, Z.; Wu, D.; Fu, R. Synthesis of SiO $/$ C composite nanosheets as high-rate and stable anode materials for lithium-ion batteries. ACS Appl. Energy Mater. 2020, 3, 3562-3568. [CrossRef]

178. Idota, Y.; Kubota, T.; Matsufuji, A.; Maekawa, Y.; Miyasaka, T. Tin-based amorphous oxide: A high-capacity lithium-ion-storage material. Science 1997, 276, 1395-1397. [CrossRef]

179. Zoller, F.; Böhm, D.; Bein, T.; Fattakhova-Rohlfing, D. Tin oxide based nanomaterials and their application as anodes in lithium-ion batteries and beyond. ChemSusChem 2019, 12, 4140-4159. [CrossRef]

180. Li, Y.; Lv, X.; Lu, J.; Li, J. Preparation of $\mathrm{SnO}_{2}$-nanocrystal/graphene-nanosheets composites and their lithium storage ability. J. Phys. Chem. C 2010, 114, 21770-21774. [CrossRef]

181. Zhao, B.; Zhang, G.; Song, J.; Jiang, Y.; Zhuang, H.; Liu, P.; Fang, T. Bivalent tin ion assisted reduction for preparing graphene/ $\mathrm{SnO}_{2}$ composite with good cyclic performance and lithium storage capacity. Electrochim. Acta 2011, 56, 7340-7346. [CrossRef]

182. Lian, P.; Zhu, X.; Liang, S.; Li, Z.; Yang, W.; Wang, H. High reversible capacity of $\mathrm{SnO}_{2}$ /graphene nanocomposite as an anode material for lithium-ion batteries. Electrochim. Acta 2011, 56, 4532-4539. [CrossRef]

183. Huang, X.; Zhou, X.; Zhou, L.; Qian, K.; Wang, Y.; Liu, Z.; Yu, C. A facile one-step solvothermal synthesis of $\mathrm{SnO}_{2}$ /graphene nanocomposite and its application as an anode material for lithium-ion batteries. ChemPhysChem 2010, 12, 278-281. [CrossRef]

184. Xie, J.; Liu, S.Y.; Chen, X.F.; Zhang, Y.X.; Song, W.T.; Cao, G.S.; Zhu, T.J.; Zhao, X.B. Nanocrystal-SnO 2 -loaded graphene with improved Li-storage properties prepared by a facile one-pot hydrothermal route. Int. J. Electrochem. Sci. 2011, 6, 5539-5549.

185. Lim, S.P.; Huang, N.M.; Lim, H.N. Solvothermal synthesis of $\mathrm{SnO}_{2} /$ graphene nanocomposites for supercapacitor application. Cream. Int. 2013, 39, 6647-6655. [CrossRef]

186. Ding, S.; Luan, D.; Boey, F.Y.C.; Chen, J.S.; Lou, X.W.D. $\mathrm{SnO}_{2}$ nanosheets grown on graphene sheets with enhanced lithium storage properties. Chem. Commun. 2011, 47, 7155-7157. [CrossRef] [PubMed]

187. Gao, T.; Huang, K.; Qi, X.; Li, H.; Yang, L.; Zhong, J. Free-standing $\mathrm{SnO}_{2}$ nanoparticles@graphene hybrid paper for advanced lithium-ion batteries. Ceram. Int. 2014, 40, 6891-6897. [CrossRef]

188. Cui, D.; Zheng, Z.; Peng, X.; Li, T.; Sun, T.; Yuan, L. Fluorine-doped $\mathrm{SnO}_{2}$ nanoparticles anchored on reduced graphene oxide as a high-performance lithium ion battery anode. J. Power Sources 2017, 362, 20-26. [CrossRef]

189. Wang, H.; Pan, Q.; Wu, Q.; Zhang, X.; Huang, Y.-G.; Lushington, A.; Li, Q.; Sun, X. Ultrasmall MoS embedded in carbon nanosheets-coated $\mathrm{Sn} / \mathrm{SnO}_{\mathrm{x}}$ as anode material for high-rate and long life Li-ion batteries. J. Mater. Chem. A 2017, 5, 4576-4582. [CrossRef]

190. Tang, J.; Yang, J.; Zhou, L.; Xie, J.; Chen, G.; Zhou, X. Layer-by-layer self-assembly of a sandwich-like graphene wrapped $\mathrm{SnO}_{\mathrm{x}} @$ graphene composite as an anode material for lithium ion batteries. J. Mater. Chem. A 2014, 2, 6292-6295. [CrossRef]

191. Cai, D.; Yang, T.; Liu, B.; Wang, D.; Liu, Y.; Wang, L.; Li, Q.; Wang, T. A nanocomposite of tin dioxide octahedral nanocrystals exposed to high-energy facets anchored onto graphene sheets for high performance lithium-ion batteries. J. Mater. Chem. A 2014, 2, 13990. [CrossRef]

192. Huang, Y.; Wu, D.; Wang, J.; Han, S.; Lv, L.; Zhang, F.; Feng, X. Amphiphilic polymer promoted assembly of macroporous graphene/ $\mathrm{SnO}_{2}$ frameworks with tunable porosity for high-performance lithium storage. Small 2014, 10, 2226-2232. [CrossRef] 


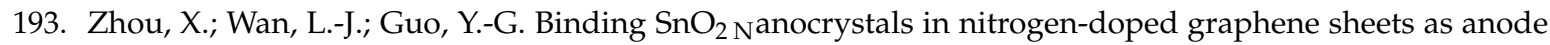
materials for lithium-ion batteries. Adv. Mater. 2013, 25, 2152-2157. [CrossRef]

194. Hu, X.; Zeng, G.; Chen, J.; Lu, C.; Wen, Z. 3D graphene network encapsulating $\mathrm{SnO}_{2}$ hollow spheres as a high-performance anode material for lithium-ion batteries. J. Mater. Chem. A 2017, 5, 4535-4542. [CrossRef]

195. Wang, S.; Shi, L.; Chen, G.; Ba, C.; Wang, Z.; Zhu, J.; Zhao, Y.; Zhang, M.; Yuan, S. In situ synthesis of tungsten-doped $\mathrm{SnO}_{2}$ and graphene nanocomposites for high-performance anode materials of lithium-ion batteries. ACS Appl. Mater. Interfaces 2017, 9, 17163-17171. [CrossRef] [PubMed]

196. Wang, D.; Li, X.; Wang, J.; Ynag, J.; Geng, D.; Li, R.; Cai, M.; Sham, T.-K.; Sun, X. defect-rich crystalline $\mathrm{SnO}_{2}$ immobilized on graphene nanosheets with enhanced cycle performance for Li ion batteries. J. Phys. Chem. C 2012, 116, 22149-22156. [CrossRef]

197. Shao, Q.; Tang, J.; Sun, Y.; Li, J.; Zhang, K.; Yuan, J.; Zhu, D.-M.; Qin, L.-C. Unique interconnected graphene/ $\mathrm{SnO}_{2}$ nanoparticle spherical multilayers for lithium-ion battery applications. Nanoscale 2017, 9, 4439-4444. [CrossRef] [PubMed]

198. Zhang, H.; Xu, P.; Ni, Y.; Geng, H.; Zheng, G.; Dong, B.; Jiao, Z. In situ chemical synthesis of $\mathrm{SnO}_{2} / \mathrm{reduced}$ graphene oxide nanocomposites as anode materials for lithium-ion batteries. J. Mater. Res. 2014, 29, 617-624. [CrossRef]

199. Chen, L.; Ma, X.; Wang, M.; Chen, C.; Ge, X. Hierarchical porous $\mathrm{SnO}_{2} /$ reduced graphene oxide composites for high-performance lithium-ion battery anodes. Electrochim. Acta 2016, 215, 42-49. [CrossRef]

200. Hou, C.-C.; Brahma, S.; Weng, S.-C.; Chang, C.-C.; Huang, J.-L. Facile, low temperature synthesis of $\mathrm{SnO}_{2} /$ reduced graphene oxide nanocomposite as anode material for lithium-ion batteries. Appl. Surf. Sci. 2017, 413, 160-168. [CrossRef]

201. Tan, Q.; Kong, Z.; Chen, X.; Zhang, L.; Hu, X.; Mu, M.; Sun, H.; Shao, X.; Guan, X.; Gao, M.; et al. Synthesis of $\mathrm{SnO}_{2}$ /graphene composite anode materials for lithium-ion batteries. Appl. Surf. Sci. 2019, 485, 314-322. [CrossRef]

202. Liu, R.; Zhang, N.; Wang, X.; Yang, C.; Cheng, H.; Zhao, H. $\mathrm{SnO}_{2}$ nanoparticles anchored on graphene oxide as advanced anode materials for high-performance lithium-ion batteries. Front. Mater. Sci. 2019, 13, 186-192. [CrossRef]

203. Jiang, W.; Zhao, X.; Ma, Z.S.; Lin, J.; Lu, C. $\mathrm{SnO}_{2}$ /reduced graphene oxide nanocomposite as anode material for lithium-ion batteries with enhanced cyclability. J. Nanosci. Nanotechnol. 2016, 16, 4136-4140. [CrossRef]

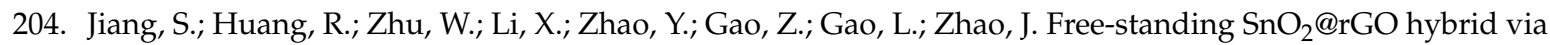
the anti-solvent-assisted precipitation for superior lithium storage performance. Front. Chem. 2019, 7, 878. [CrossRef]

205. Wu, Y.-Z.; Brahma, S.; Weng, S.-C.; Chang, C.-C.; Huang, J.-L. Reduced graphene oxide (RGO)-SnO $(x=0,1,2)$ nanocomposite as high performance anode material for lithium-ion batteries. J. Alloys Compd. 2020, 818, 152889. [CrossRef]

206. Wang, J.; Wang, L.; Zhang, S.; Liang, S.; Liang, X.; Huang, H.; Zhou, W.; Guo, J. Facile synthesis of iron-doped $\mathrm{SnO}_{2}$ /reduced graphene oxide composite as high-performance anode material for lithium-ion batteries. J. Alloys Compd. 2018, 748, 1013-1021. [CrossRef]

207. Huang, Z.; Chen, Z.; Ding, S.; Chen, C.; Zhang, M. Enhanced electrochemical properties of $\mathrm{SnO}_{2}$-graphene-carbon nanofibers tuned by phosphoric acid for potassium storage. Nanotechnology 2018, 29, 375702. [CrossRef] [PubMed]

208. Zoller, F.; Peters, K.; Zehetmaier, P.M.; Zeller, P.; Dçblinger, M.; Bein, T.; Sofer, Z.; Fattakhova-Rohlfing, D. Making ultrafast high-capacity anodes for lithium-ion batteries via antimony doping of nanosized tin oxide/graphene composites. Adv. Funct. Mater. 2018, 28, 1706529. [CrossRef]

209. Sun, J.; Xiao, L.; Jiang, S.; Li, G.; Huang, Y.; Geng, J. Fluorine-doped $\mathrm{SnO}_{2} @$ graphene porous composite for high capacity lithium-ion batteries. Chem. Mater. 2015, 27, 4594-4603. [CrossRef]

210. Zhang, Y.; Wang, R.; Zheng, Z.; Li, T.; Tong, Z.; Ai, C. Fluorine-doped $\mathrm{SnO}_{2} /$ reduced graphene oxide-artificial graphite hybrids as lithium-ion battery anodes with stable capacity. Ionics 2020, 26, 2835-2843. [CrossRef]

211. Dong, W.; Xu, J.; Wang, C.; Lu, Y.; Liu, X.; Wang, X.; Yuan, X.; Wang, Z.; Lin, T.; Sui, M.; et al. A robust and conductive black tin oxide nanostructure makes efficient lithium-ion batteries possible. Adv. Mater. 2017, 29, 1700136. [CrossRef] 
212. Dou, P.; Cao, Z.; Wang, C.; Zheng, J.; Xu, X. Multilayer Zn-doped $\mathrm{SnO}_{2}$ hollow nanospheres encapsulated in covalently interconnected three-dimensional graphene foams for high performance lithium-ion batteries. Chem. Eng. J. 2017, 320, 405-415. [CrossRef]

213. Kokubu, T.; Oaki, Y.; Hosono, E.; Zhou, H.; Imai, H. Biomimetic solid-solution precursors of metal carbonate for nanostructured metal oxides: $\mathrm{MnO} / \mathrm{Co}$ and $\mathrm{MnO}-\mathrm{CoO}$ nanostructures and their electrochemical properties. Adv. Funct. Mater. 2011, 21, 3673-3680. [CrossRef]

214. Wu, Y.; Liu, S.; Wang, H.; Wang, X.; Zhang, X.; Jin, G. A novel solvothermal synthesis of $\mathrm{Mn}_{3} \mathrm{O}_{4} /$ graphene composites for supercapacitors. Electrochim. Acta 2013, 90, 210-218. [CrossRef]

215. Qiu, Y.; Xu, G.-L.; Yan, K.; Sun, H.; Xiao, J.; Yang, S.; Sun, S.; Jin, L.; Deng, H. Morphology-conserved transformation: Synthesis of hierarchical mesoporous nanostructures of $\mathrm{Mn}_{2} \mathrm{O}_{3}$ and the nanostructural effects on Li-ion insertion/deinsertion properties. J. Mater. Chem. 2011, 21, 6346-6353. [CrossRef]

216. Li, L.; Raji, A.-R.O.; Tour, J.M. Graphene-wrapped $\mathrm{MnO}_{2}$-graphene nanoribbons as anode materials for high-performance lithium ion batteries. Adv. Mater. 2013, 25, 6298-6302. [CrossRef] [PubMed]

217. Yousefi, T.; Golikand, A.N.; Mashhadizadeh, M.H.; Aghazadeh, M. Facile synthesis of $\alpha-\mathrm{MnO}_{2}$ one-dimensional (1D) nanostructure and energy storage ability studies. J. Solid State Chem. 2012, 190, 202-207. [CrossRef]

218. Liu, Y.; Yan, D.; Li, Y.; Wu, Z.; Zhuo, R.; Li, S.; Feng, J.; Wang, J.; Yan, P.; Geng, Z. Manganese dioxide nanosheet arrays grown on graphene oxide as an advanced electrode material for supercapacitors. Electrochim. Acta 2014, 117, 528-533. [CrossRef]

219. Yang, Y.; Ma, G.; Huang, J.; Nan, J.; Zhen, S.; Wang, Y.; Li, A. Hollow $\mathrm{MnO}_{2}$ spheres/porous reduced graphene oxide as a cathode host for high-performance lithium-sulfur batteries. J. Solid State Chem. 2020, 286, 121297. [CrossRef]

220. Majid, S.R. Green synthesis of in situ electrodeposited $\mathrm{rGO} / \mathrm{MnO}_{2}$ nanocomposite for high energy density supercapacitors. Sci. Rep. 2015, 5, 16195. [CrossRef]

221. Sawangphruk, M.; Srimuk, P.; Chiochan, P.; Krittayavathananon, A.; Luanwuthi, S.; Limtrakul, J. High-performance supercapacitor of manganese oxide/reduced graphene oxide nanocomposite coated on flexible carbon fiber paper. Carbon 2013, 60, 109-116. [CrossRef]

222. Gund, G.S.; Dubal, D.P.; Patil, B.H.; Shinde, S.S.; Lokhande, C.D. Enhanced activity of chemically synthesized hybrid graphene oxide/ $\mathrm{Mn}_{3} \mathrm{O}_{4}$ composite for high performance supercapacitors. Electrochim. Acta 2013, 92, 205-215. [CrossRef]

223. Wang, L.; Wang, D.-L. Preparation and electrochemical characterization of MnOOH nanowire-graphene oxide. Electrochim. Acta 2011, 56, 5010-5015. [CrossRef]

224. Chen, T.; Zhiu, Y.; Zhang, J.; Cao, Y. Two-dimensional $\mathrm{MnO}_{2} /$ reduced graphene oxide nanosheet as a high-capacity and high-rate cathode materials for lithium-ion batteries. Int. J. Electrochem. Sci. 2018, 13, 8575-8588. [CrossRef]

225. Lee, S.-W.; Lee, C.-W.; Yoon, S.-B.; Kim, M.-S.; Jeong, J.H.; Nam, K.-W.; Roh, K.C.; Kim, K.-B. Superior electrochemical properties of manganese dioxide/reduced graphene oxide nanocomposites as anode materials for high-performance lithium ion batteries. J. Power Sources 2016, 312, 207-215. [CrossRef]

226. Devi, P.; Bansod, B.; Kaur, M.; Bagchi, S.; Nayak, M.K. Co-electrodeposited $\mathrm{rGO} / \mathrm{MnO}_{2}$ nanohybrid for arsenite detection in water by stripping voltammetry. Sensors Actuators B Chem. 2016, 237, 652-659. [CrossRef]

227. Zhang, L.; Liu, H.; Ruan, H.; Su, Y.; Hu, R.; Tian, L.; Hu, Z.; Li, J. Fabrication of $\beta-\mathrm{MnO}_{2} / \mathrm{rGO}$ composite and its electrochemical properties. Int. J. Electrochem. Sci. 2016, 11, 10815-10826. [CrossRef]

228. Liu, H. Preparation of $\left(\mathrm{MnO}_{2} / \mathrm{RGO}\right) / \mathrm{Li}_{7} \mathrm{La}_{3} \mathrm{Zr}_{2} \mathrm{O}_{12} / \mathrm{LiCoO}_{2}$ Solid State Lithium Ion Batteries and Theirs Electrochemical Performance. Int. J. Electrochem. Sci. 2017, 12, 11479-11486. [CrossRef]

229. Ali, G.A.; Yusoff, M.; Algarni, H.; Chong, K.F. One-step electrosynthesis of $\mathrm{MnO}_{2} / \mathrm{rGO}$ nanocomposite and its enhanced electrochemical performance. Ceram. Int. 2018, 44, 7799-7807. [CrossRef]

230. Liu, H.D.; Hu, Z.L.; Su, Y.Y.; Ruan, H.B.; Hu, R.; Zhang, L. $\mathrm{MnO}_{2}$ nanorods/3D-rGO composite as high performance anode materials for Li-ion batteries. Appl. Surf. Sci. 2017, 392, 777-784. [CrossRef]

231. Cao, Y.; Lin, X.; Zhang, C.; Yang, C.; Zhang, Q.; Hu, W.; Zheng, M.; Dong, Q. $\mathrm{MnO}_{2}$ nanoflakes anchored on reduced graphene oxide nanosheets as high performance anode materials for lithium-ion batteries. RSC Adv. 2014, 4, 30150-30155. [CrossRef] 
232. Chae, C.; Kim, K.W.; Yun, Y.J.; Lee, D.; Moon, J.; Choi, Y.; Lee, S.S.; Choi, S.; Jeong, S. Polyethyleniminemediated electrostatic assembly of $\mathrm{MnO}_{2}$ nanorods on graphene oxides for use as anodes in lithium-ion batteries. ACS Appl. Mater. Interfaces 2016, 8, 11499-11506. [CrossRef]

233. Zhang, Y.; Liu, H.; Zhu, Z.; Wong, K.; Mi, R.; Mei, J.; Lau, W. A green hydrothermal approach for the preparation of graphene $/ \alpha-\mathrm{MnO}_{2} 3 \mathrm{D}$ network as anode for lithium ion battery. Electrochim. Acta 2013, 108, 465-471. [CrossRef]

234. Ma, Z.; Zhao, T. Reduced graphene oxide anchored with $\mathrm{MnO}_{2}$ nanorods as anode for high rate and long cycle Lithium ion batteries. Electrochim. Acta 2016, 201, 165-171. [CrossRef]

235. Li, Y.; Ye, D.; Liu, W.; Shi, B.; Guo, R.; Pei, H.; Xie, J. A three-dimensional core-shell nanostructured composite of polypyrrole wrapped $\mathrm{MnO}_{2}$ /reduced graphene oxide/carbon nanotube for high performance lithium ion batteries. J. Colloid Interface Sci. 2017, 493, 241-248. [CrossRef] [PubMed]

236. Li, S.; Zhao, Y.; Liu, Z.; Yang, L.; Zhang, J.; Wang, M.; Che, R. Flexible graphene-wrapped carbon nanotube/graphene@ $\mathrm{MnO}_{2}$ 3D multilevel porous film for high-performance lithium-ion batteries. Small 2018, 14, 1801007. [CrossRef] [PubMed]

237. Kim, S.J.; Yun, Y.J.; Kim, K.W.; Chae, C.; Jeong, S.; Kang, Y.; Choi, S.-Y.; Lee, S.S.; Choi, S. Superior lithium storage performance using sequentially stacked $\mathrm{MnO}_{2}$ /reduced graphene oxide composite electrodes. ChemSusChem 2015, 8, 1484-1491. [CrossRef] [PubMed]

238. Li, Y.; Ye, D.; Shi, B.; Liu, W.; Guo, R.; Pei, H.; Xie, J. Free-standing reduced graphene oxide/ $\mathrm{MnO}_{2}-$ reduced graphene oxide-carbon nanotube nanocomposite flexible membrane as an anode for improving lithium-ion batteries. Phys. Chem. Chem. Phys. 2017, 19, 7498-7505. [CrossRef] [PubMed]

239. Li, X.; Xu, X.; Xia, F.; Bu, L.; Qiu, H.; Chen, M.; Zhang, L.; Gao, J. Electrochemically active $\mathrm{MnO}_{2} / \mathrm{RGO}$ nanocomposites using $\mathrm{Mn}$ powder as the reducing agent of $\mathrm{GO}$ and the $\mathrm{MnO}_{2}$ precursor. Electrochim. Acta 2014, 130, 305-313. [CrossRef]

240. Han, G.; Liu, Y.; Zhang, L.; Kan, E.; Zhang, S.; Tang, J.; Tang, W. $\mathrm{MnO}_{2}$ nanorods intercalating graphene oxide/polyaniline ternary composites for robust high-performance supercapacitors. Sci. Rep. 2015, 4, 4824. [CrossRef]

241. Chan, P.Y.; Rusi, R.; Majid, S. RGO-wrapped $\mathrm{MnO}_{2}$ composite electrode for supercapacitor application. Solid State Ionics 2014, 262, 226-229. [CrossRef]

242. Zhu, S.; Zhang, H.; Chen, P.; Nie, L.H.; Li, C.-H.; Li, S.K. Self-assembled three-dimensional hierarchical graphene hybrid hydrogels with ultrathin $\beta-\mathrm{MnO}_{2}$ nanobelts for high performance supercapacitors. J. Mater. Chem. A 2015, 3, 1540-1548. [CrossRef]

243. Chen, S.; Zhu, J.W.; Wu, X.D.; Han, Q.F.; Wang, X. Graphene oxide- $\mathrm{MnO}_{2}$ nanocomposites for supercapacitors. ACS Nano 2010, 4, 2822-2830. [CrossRef]

244. Lu, L.; Xu, S.; An, J.; Yan, S. Electrochemical performance of CNTs/RGO/MnO 2 composite material for supercapacitor. Nanomater. Nanotechnol. 2016, 6, 1-7. [CrossRef]

245. Hareesh, K.; Shateesh, B.; Joshi, R.P.; Williams, J.F.; Phase, D.M.; Haram, S.K.; Dhole, S.D. Ultra high stable supercapacitance performance of conducting polymer coated $\mathrm{MnO}_{2}$ nanorods/rGO nanocomposites. RSC Adv. 2017, 7, 20027-20036. [CrossRef]

246. Seredych, M.; Bandosz, T.J. Evaluation of $\mathrm{GO} / \mathrm{MnO}_{2}$ composites as supercapacitors in neutral electrolytes: Role of graphite oxide oxidation level. J. Mater. Chem. 2012, 22, 23525-23533. [CrossRef]

247. Pang, M.; Long, G.; Jiang, S.; Ji, Y.; Han, W.; Wang, B.; Liu, X.; Xi, Y. Rapid synthesis of graphene/amorphous $\alpha-\mathrm{MnO}_{2}$ composite with enhanced electrochemical performance for electrochemical capacitor. Mater. Sci. Eng. B 2015, 194, 41-47. [CrossRef]

248. Miniach, E.; Śliwak, A.; Moyseowicz, A.; Fernández-Garcia, L.; González, Z.; Granda, M.; Menendez, R.; Gryglewicz, G. $\mathrm{MnO}_{2} /$ thermally reduced graphene oxide composites for high-voltage asymmetric supercapacitors. Electrochim. Acta 2017, 240, 53-62. [CrossRef]

249. Chen, J.; Wang, Y.; Cao, J.; Liu, Y.; Ouyang, J.-H.; Jia, D.; Zhou, Y. Flexible and solid-state asymmetric supercapacitor based on ternary graphene/ $\mathrm{MnO}_{2} /$ carbon black hybrid film with high power performance. Electrochim. Acta 2015, 182, 861-870. [CrossRef]

250. Zardkhoshoui, A.M.; Davarani, S.S.H. Flexible asymmetric supercapacitors based on $\mathrm{CuO} @ \mathrm{MnO}_{2}-\mathrm{rGO}$ and $\mathrm{MoS}_{2}$-rGO with ultrahigh energy density. J. Electroanal. Chem. 2018, 827, 221-229. [CrossRef] 
251. Wang, K.; Li, L.; Xue, W.; Zhou, S.; Lan, Y.; Zhang, H.; Sui, Z. Electrodeposition synthesis of $\mathrm{PANI} / \mathrm{MnO}_{2} /$ graphene composite materials and its electrochemical performance. Int. J. Electrochem. Sci. 2017, 12, 8306-8314.

252. Dong, W.; Meng, L.; Hong, X.; Liu, S.; Shen, D.; Xia, Y.; Yang, S. $\mathrm{MnO}_{2} / \mathrm{rGO} / \mathrm{CNTs}$ framework as a sulfur host for high-performance Li-S batteries. Molecules 2020, 25, 1989. [CrossRef]

253. Jie, G.; Michael, A.L.; Hector, D.A. Sponge like nanosized $\mathrm{Mn}_{3} \mathrm{O}_{4}$ as a high-capacity anode material for rechargeable lithium batteries. Chem. Mater. 2011, 23, 3223-3227.

254. Su, Q.; Wang, S.; Du, G.; Xu, B.; Ma, S.; Shang, L. Microstructure evolution and conversion mechanism of $\mathrm{Mn}_{3} \mathrm{O}_{4}$ under electrochemical cyclings. J. Phys. Chem. C 2018, 122, 2475-2480. [CrossRef]

255. Wang, H.; Cui, L.-F.; Yang, Y.; Casalongue, H.S.; Robinson, J.T.; Liang, Y.; Cui, Y.; Dai, H. $\mathrm{Mn}_{3} \mathrm{O}_{4}-$ graphene hybrid as a high-capacity anode material for lithium-ion batteries. J. Am. Chem. Soc. 2010, 132, 13978-13980. [CrossRef] [PubMed]

256. Zhou, Y.; Guo, L.; Shi, W.; Zou, X.; Xiang, B.; Xing, S. Rapid production of $\mathrm{Mn}_{3} \mathrm{O}_{4} / \mathrm{rGO}$ as an efficient electrode material for supercapacitor by flame plasma. Materials 2018, 11, 881. [CrossRef] [PubMed]

257. Wang, Y. Coprecipitated 3D nanostructured graphene oxide- $\mathrm{Mn}_{3} \mathrm{O}_{4}$ hybrid as anode for lithium-ion batteries. J. Mater. Res. 2015, 30, 484-492. [CrossRef]

258. Li, Q.; Li, Y.; Fulari, A.; Ghodake, G.; Kim, D.; Lohar, G.M. Performance of chemically synthesized $\mathrm{Mn}_{3} \mathrm{O}_{4} / \mathrm{rGO}$ nanocomposite for electrochemical supercapacitor: A cost-effective high-performance electrode. Nanotechnology 2020, 31, 415403. [CrossRef]

259. Wang, L.; Ouyang, Y.; Jiao, X.; Xia, X.; Lei, W.; Hao, Q. Polyaniline-assisted growth of $\mathrm{MnO}_{2}$ ultrathin nanosheets on graphene and porous graphene for asymmetric supercapacitor with enhanced energy density. Chem. Eng. J. 2018, 334, 1-9. [CrossRef]

260. Liu, M.; Shi, M.; Lu, W.; Zhu, D.; Li, L.; Gan, L. Core-shell reduced graphene oxide/MnOx@carbon hollow nanospheres for high performance supercapacitor electrodes. Chem. Eng. J. 2017, 313, 518-526. [CrossRef]

261. Wang, Y.; Lai, W.H.; Wang, N. A reduced graphene oxide/mixed-valent manganese oxides composite electrode for tailorable and surface mountable supercapacitors with high capacitance and super-long life. Energy Environ. Sci. 2017, 10, 941-949. [CrossRef]

262. Seong, C.-Y.; Park, S.-K.; Bae, Y.; Yoo, S.; Piao, Y. An acid-treated reduced graphene oxide/ $\mathrm{Mn}_{3} \mathrm{O}_{4}$ nanorod nanocomposite as an enhanced anode material for lithium ion batteries. RSC Adv. 2017, 7, 37502-37507. [CrossRef]

263. Wang, J.; Guan, C.; Feng, G.; Ke, Q.; Huang, X.; Wang, J. Flexible asymmetric supercapacitor based on structure-optimized $\mathrm{Mn}_{3} \mathrm{O}_{4}$ /reduced Graphene oxide nanohybrid paper with high energy and power density. Adv. Funct. Mater. 2015, 25, 7291-7299. [CrossRef]

264. Gu, Y.; Wu, J.; Wang, X.; Liu, W.; Yan, S. Producing symbiotic reduced graphene oxide $/ \mathrm{Mn}_{3} \mathrm{O}_{4}$ nanocoposites directly from converting graphite for high-performance supercapacitor electrodes. ACS Omega 2020, 5 , 18975-18986. [CrossRef]

265. Li, Y.; Gai, T.; Shao, L.; Tang, H.; Li, R.; Yang, S.; Wang, S.; Wu, Q.; Ren, Y. Synthesis of sandwich-like $\mathrm{Mn}_{3} \mathrm{O}_{4} @$ reduced graphene oxide nano-composites via modified Hummers' method and its application as uranyl adsorbents. Heliyon 2019, 5, e01972. [CrossRef] [PubMed]

266. Raj, B.G.S.; Ramprasad, R.N.R.; Asiri, A.M.; Wu, J.J.; Anandan, S. Ultrasound assisted synthesis of $\mathrm{Mn}_{3} \mathrm{O}_{4}$ nanoparticles anchored graphene nanosheets for supercapacitor applications. Electrochim. Acta 2015, 156, 127-137. [CrossRef]

267. Park, G.; Bartolome, L.; Lee, K.G.; Lee, S.J.; Kim, D.H.; Park, T.J. One-step sonochemical synthesis of a graphene oxide-manganese oxide nanocomposite for catalytic glycolysis of polu(ethylene terephthalate). Nanoscale 2012, 4, 3879-3885. [CrossRef] [PubMed]

268. Ayhan, I.A.; Meduri, P.; Oh, H.; Bhimanapati, G.R.; Li, Q.; Yang, G.; Robinson, J.A.; Wang, Q. Effect of $\mathrm{Mn}_{3} \mathrm{O}_{4}$ nanoparticle composition and distribution on graphene as a potential hybrid anode material for lithium-ion batteries. RSC Adv. 2016, 6, 33022-33030. [CrossRef]

269. Park, S.-H.; Lee, W.-J. Hierarchically mesoporous CuO/carbon nanofiber coaxial shell-core nanowires for lithium ion batteries. Sci. Rep. 2015, 5, 9754. [CrossRef] [PubMed]

270. Rosaiah, P.; Zhu, J.; Shaik, D.P.M.D.; Hussain, O.M.; Qiu, Y.; Zhao, L. Reduced graphene oxide $/ \mathrm{Mn}_{3} \mathrm{O}_{4}$ nanocomposite electrodes with enhanced electrochemical performance for energy storage applications. J. Electroanal. Chem. 2017, 794, 78-85. [CrossRef] 
271. Nithya, C.; Vishnuprakash, P.; Gopukumar, S. A $\mathrm{Mn}_{3} \mathrm{O}_{4}$ nanospheres@rGO architecture with capacitive effects on high potassium storage capability. Nanoscale Adv. 2019, 1, 4347-4358. [CrossRef]

272. Nam, I.; Kim, N.D.; Kim, G.-P.; Park, J.; Yi, J. One step preparation of $\mathrm{Mn}_{3} \mathrm{O}_{4} /$ graphene composites for use as an anode in Li ion batteries. J. Power Sources 2013, 244, 56-62. [CrossRef]

273. Luo, Y.; Fan, S.; Hao, N.; Zhong, S.; Liu, W. An ultrasound-assisted approach to synthesize $\mathrm{Mn}_{3} \mathrm{O}_{4} / \mathrm{RGO}$ hybrids with high capability for lithium ion batteries. Dalton Trans. 2014, 43, 15317-15320. [CrossRef]

274. Li, S.; Yu, L.-L.; Shi, Y.-T.; Fan, J.; Li, R.-B.; Fan, G.-D.; Xu, W.-L.; Zhao, J.-T. Greatly Enhanced Faradic Capacities of 3D Porous $\mathrm{Mn}_{3} \mathrm{O}_{4} / \mathrm{G}$ Composites as Lithium-Ion Anodes and Supercapacitors by C-O-Mn Bonding. ACS Appl. Mater. Interfaces 2019, 11, 10178-10188. [CrossRef]

275. Zhang, R.; Wang, D.; Qin, L.-C.; Wen, G.; Pan, H.; Zhang, Y.; Tian, N.; Zhou, Y.; Huang, X. $\mathrm{MnCO}_{3} / \mathrm{Mn}_{3} \mathrm{O}_{4} /$ reduced graphene oxide ternary anode materials for lithium-ion batteries: Facile green synthesis and enhanced electrochemical performance. J. Mater. Chem. A 2017, 5, 17001-17011. [CrossRef]

276. Shah, H.U.; Wang, F.; Javed, M.S.; Shaheen, N.; Saleem, M.; Li, Y. Hydrothermal synthesis of reduced graphene oxide $-\mathrm{Mn}_{3} \mathrm{O}_{4}$ nanocomposite as an efficient electrode material for supercapacitors. Ceram. Int. 2018, 44, 3580-3584. [CrossRef]

277. Varghese, S.P.; Babu, B.; Prasannachandran, R.; Antony, R.; Shaijumon, M.M. Enhanced electrochemical properties of $\mathrm{Mn}_{3} \mathrm{O}_{4} /$ graphene nanocomposite as efficient anode material for lithium ion batteries. J. Alloys Compd. 2019, 780, 588-596. [CrossRef]

278. Petnikota, S.; Srikanth, V.V.S.S.; Nithyadharseni, P.; Reddy, M.V.; Adams, S.; Chowdari, B.V.R. Sustainable graphenothermal reduction chemistry to obtain $\mathrm{MnO}$ nanonetwork supported exfoliated graphene oxide composite and its electrochemical characteristics. ACS Sustain. Chem. Eng. 2015, 3, 3205-3213. [CrossRef]

279. Yuan, T.; Xu, B.; Sun, W.; Xiang, B.; Li, Y.; Yan, M.; Xu, B.; Dou, S. Ever-Increasing Pseudocapacitance in RGO-MnO-RGO Sandwich Nanostructures for Ultrahigh-Rate Lithium Storage. Adv. Funct. Mater. 2016, 26, 2198-2206. [CrossRef]

280. Cheng, F.; Zhou, X.; Yang, J.; Sun, A.; Wang, H.; Tang, J. MnO nanoparticles sandwiched within 3D graphene-based hierarchical architecture for efficient lithium storage. Inorg. Chem. 2019, 58, 3329-3337. [CrossRef]

281. Wang, Y.; Wu, H.; Liu, Z.; Zhao, H.; Liu, H.; Zhang, Y. Bottom-up construction of reduced-grapheneoxide-anchored $\mathrm{MnO}$ with an nitrogen-doped carbon coating for synergistically improving lithium-ion storage. Inorg. Chem. 2018, 57, 13693-13701. [CrossRef]

282. Hsieh, C.-T.; Lin, C.-Y.; Lin, J.-Y. High reversibility of Li intercalation and de-intercalation in MnO-attached graphene anodes for Li-ion batteries. Electrochim. Acta 2011, 56, 8861-8867. [CrossRef]

283. Zhang, K.; Han, P.; Gu, L.; Zhang, L.; Liu, Z.; Kong, Q.; Zhang, C.; Dong, S.; Zhang, Z.; Yao, J.; et al. Synthesis of nitrogen-doped $\mathrm{MnO} /$ graphene nanosheets hybrid material for lithium ion batteries. ACS Appl. Mater. Interfaces 2012, 4, 658-664. [CrossRef]

284. Qiu, D.; Ma, L.; Zheng, M.; Lin, Z.; Zhao, B.; Wen, Z.; Hu, Z.; Pu, L.; Shi, Y. MnO nanoparticles anchored on graphene nanosheets via in situ carbothermal reduction as high-performance anode materials for lithium-ion batteries. Mater. Lett. 2012, 84, 9-12. [CrossRef]

285. Liu, S.-Y.; Xie, J.; Zheng, Y.-X.; Cao, G.-S.; Zhu, T.-J.; Zhao, X. Nanocrystal manganese oxide $\left(\mathrm{Mn}_{3} \mathrm{O}_{4}, \mathrm{MnO}\right)$ anchored on graphite nanosheet with improved electrochemical Li-storage properties. Electrochim. Acta 2012, 66, 271-278. [CrossRef]

286. Mai, Y.; Zhang, D.; Qiao, Y.; Gu, C.; Wang, X.; Tu, J. MnO/reduced graphene oxide sheet hybrid as an anode for Li-ion batteries with enhanced lithium storage performance. J. Power Sources 2012, 216, 201-207. [CrossRef]

287. Zhang, S.; Zhu, L.; Song, H.; Chen, X.; Zhou, J. Enhanced electrochemical performance of MnO nanowire/graphene composite during cycling as the anode material for lithium-ion batteries. Nano Energy 2014, 10, 172-180. [CrossRef]

288. Wu, T.; Tu, F.; Liu, S.; Zhuang, S.; Jin, G.; Pan, C. MnO nanorods on graphene as an anode material for high capacity lithium ion batteries. J. Mater. Sci. 2013, 49, 1861-1867. [CrossRef]

289. Zang, J.; Qian, H.; Wei, Z.; Cao, Y.; Zheng, M.; Dong, Q. Reduced graphene oxide supported MnO nanoparticles with excellent lithium storage performance. Electrochim. Acta 2014, 118, 112-117. [CrossRef]

290. Jiang, X.; Zhu, X.; Liu, X.; Xiao, L.; Ai, X.; Yang, H.; Cao, Y. Nanospherical-like manganese monoxide/reduced graphene oxide composite Synthesized by rlectron beam radiation as anode Material for high-performance lithium-ion batteries. Electrochim. Acta 2016, 196, 431-439. [CrossRef] 
291. Auborn, J.J.; Barberio, Y.L. Lithium intercalation cells without metallic lithium: $\mathrm{MoO}_{2} / \mathrm{LiCoO}_{2}$ and $\mathrm{WO}_{2} / \mathrm{LiCoO}_{2}$. J. Electrochem. Soc. 1987, 134, 638-640. [CrossRef]

292. Rogers, D.B.; Shannon, R.D.; Sleight, A.W.; Gillson, J.L. Crystal chemistry of metal dioxides with rutile-related structures. Inorg. Chem. 1969, 8, 841-849. [CrossRef]

293. Shi, Y.; Guo, B.; Corr, S.A.; Shi, Q.; Hu, Y.-S.; Heier, K.R.; Chen, L.; Seshadri, R.; Stucky, G.D. Ordered mesoporous metallic $\mathrm{MoO}_{2}$ materials with highly reversible lithium storage capacity. Nano Lett. 2009, 9, 4215-4220. [CrossRef]

294. Wang, Y.; Huang, Z. A new approach to synthesize $\mathrm{MoO}_{2} @ \mathrm{C}$ for high-rate lithium ion batteries. J. Mater. Chem. A 2015, 3, 21314-21320. [CrossRef]

295. Sen, U.K.; Shaligram, A.; Mitra, S. Intercalation anode material for lithium ion battery based on molybdenum dioxide. ACS Appl. Mater. Interfaces 2014, 6, 14311-14319. [CrossRef] [PubMed]

296. Zhang, H.-J.; Wu, T.-H.; Wang, K.-X.; Wu, X.-Y.; Chen, X.-T.; Jiang, Y.-M.; Wei, X.; Chen, J.-S. Uniform hierarchical $\mathrm{MoO}_{2} /$ carbon spheres with high cycling performance for lithium ion batteries. J. Mater. Chem. A 2013, 1, 12038-12043. [CrossRef]

297. Petnikota, S.; Teo, K.W.; Chen, L.; Sim, A.; Marka, S.K.; Reddy, M.V.; Srikanth, V.V.S.S.; Adams, S.; Chowdari, B. Exfoliated graphene oxide/ $\mathrm{MoO}_{2}$ composites as anode materials in Lithium-ion batteries: An insight into intercalation of $\mathrm{Li}$ and conversion mechanism of $\mathrm{MoO}_{2}$. ACS Appl. Mater. Interfaces 2016, 8, 10884-10896. [CrossRef] [PubMed]

298. Hu, S.; Yin, F.; Uchaker, E.; Chen, W.; Zhang, M.; Zhou, J.; Qi, Y.; Cao, G. Facile and green preparation for the formation of $\mathrm{MoO}_{2}-\mathrm{GO}$ composites as anode material for lithium-ion batteries. J. Phys. Chem. C 2014, 118, 24890-24897. [CrossRef]

299. Qian, Y.; Lu, S.; Gao, F. Preparation of $\mathrm{MoO}_{2}$ /graphene composite as electrode material for supercapacitors. J. Mater. Sci. 2011, 46, 3517-3522. [CrossRef]

300. Huang, J.; Xu, Z.; Cao, L.; Zhang, Q.; Ouyang, H.; Li, J. Tailoring $\mathrm{MoO}_{2}$ /graphene oxide nanostructures for stable, high-density sodium-ion battery anodes. Energy Technol. 2015, 3, 1108-1114. [CrossRef]

301. Tang, W.; Peng, C.X.; Nai, C.T.; Su, J.; Liu, Y.P.; Reddy, M.V.V.; Lin, M.; Loh, K.P. Ultrahigh capacity due to multi-electron conversion reaction in reduced graphene oxide-wrapped $\mathrm{MoO}_{2}$ porous nanobelts. Small 2015, 11, 2446-2453. [CrossRef]

302. Zhu, Y.; Xu, X.; Chen, G.; Zhong, Y.; Cai, R.; Li, L.; Shao, Z. Surfactant-free self-assembly of reduced graphite oxide-MoO2 nanobelt composites used as electrode for lithium-ion batteries. Electrochim. Acta 2016, 211, 972-981. [CrossRef]

303. Ju, P.; Zhu, Z.; Shao, X.; Wang, S.; Zhao, C.; Qian, X.; Zhao, C. 3D walnut-shaped TiO $2 / \mathrm{RGO} \mathrm{MoO}_{2} @ M o$ electrode exhibiting extraordinary supercapacitor performance. J. Mater. Chem. A 2017, 5, 18777-18785. [CrossRef]

304. Hwang, J.; Yoon, D.; Kweon, B.; Chang, W.; Kim, J. A simple, one-pot synthesis of molybdenum oxide-reduced graphene oxide composites in supercritical methanol and their electrochemical performance. RSC Adv. 2016, 6, 108298-108309. [CrossRef]

305. Xu, Z.; Yao, K.; Fu, H.; Shen, X.; Duan, X.; Cao, L.; Huang, J.; Wang, H. Constructing $\mathrm{MoO}_{2}$ porous architectures using graphene oxide flexible supports for lithium io battery anodes. Glob. Chall. 2017, 1, 7. [CrossRef]

306. Wang, S.; Liu, B.; Zhi, G.; Xu, G.; Wang, Q.; Zhang, J. 2D layered mesoporous $\mathrm{MoO}_{2} / \mathrm{rGO}$ composites for high performance anode materials in lithium-ion battery. Microporous Mesoporous Mater. 2017, 246, 14-23. [CrossRef]

307. Chen, X.; Liu, R.; Zeng, L.; Huang, X.; Fang, Y.; Liu, J.; Xu, Y.; Chen, Q.; Wei, M.; Qian, Q. Preparation of hierarchical $\mathrm{MoO}_{2} @ \mathrm{RGO}$ composite and its application for high rate performance lithium-ion batteries. Mater. Lett. 2018, 212, 198-201. [CrossRef]

308. Li, F.; Li, L.; Wang, W.; Gao, J. A new facile approach to prepare reduced graphene oxide and $\mathrm{MoO}_{2} /$ reduced graphene oxide as electrode materials for oxygen reduction reactions. J. Colloid Interface Sci. 2018, 519, 194-202. [CrossRef]

309. Liu, C.-L.; Luo, S.-H.; Huang, H.-B.; Zhai, Y.-C.; Wang, Z.-W. Direct growth of $\mathrm{MoO}_{2} /$ reduced graphene oxide hollow sphere composites as advanced anode materials for potassium-ion batteries. ChemSusChem 2019, 12, 873-880. [CrossRef] 
310. Li, M.; Zhu, Y.; Ji, X.; Cheng, S. Facile synthesis of $\mathrm{MoO}_{2} / \mathrm{Mo}-\mathrm{GO}$ with high initial columbic efficiency and enhanced lithiation ability. Mater. Lett. 2019, 254, 332-335. [CrossRef]

311. Devina, W.; Hwang, J.; Kim, J. Synthesis of $\mathrm{MoO}_{2} / \mathrm{Mo}_{2} \mathrm{C} / \mathrm{rGO}$ composite in supercritical fluid and its enhanced cycling stability in Li-ion batteries. Chem. Eng. J. 2018, 345, 1-12. [CrossRef]

312. Zhang, R.; Tang, Z.; Wang, H.; Sun, D.; Tang, Y.; Xie, Z. The fabrication of hierarchical $\mathrm{MoO}_{2} @ \mathrm{MoS}_{2} / \mathrm{rGO}$ composite as high reversible anode material for lithium ion batteries. Electrochim. Acta 2020, 364, 136996. [CrossRef]

313. Xia, F.; Hu, X.; Sun, Y.; Luo, W.; Han, J. Layer-by-layer assembled $\mathrm{MoO}_{2}$-graphene thin film as a high-capacity and binder-free anode for lithium-ion batteries. Nanoscale 2012, 4, 4707. [CrossRef]

314. Xu, Y.; Yi, R.; Yuan, B.; Wu, X.; Dunwell, M.; Lin, Q.; Fei, L.; Deng, S.; Andersen, P.; Wang, D.; et al. High capacity $\mathrm{MoO}_{2}$ /graphite oxide composite anode for lithium-ion batteries. J. Phys. Chem. Lett. 2012, 3, 309-314. [CrossRef]

315. Tang, Q.; Shan, Z.; Wang, L.; Qin, X. $\mathrm{MoO}_{2}$-graphene nanocomposite as anode material for lithium-ion batteries. Electrochim. Acta 2012, 79, 148-153. [CrossRef]

316. Seng, K.H.; Du, G.D.; Li, L.; Chen, Z.X.; Liu, H.K.; Guo, Z. Facile synthesis of graphene-molybdenum dioxide and its lithium storage properties. J. Mater. Chem. 2012, 22, 16072. [CrossRef]

317. Guo, L.; Wang, Y. Standing carbon-coated molybdenum dioxide nanosheets on graphene: Morphology evolution and lithium ion storage properties. J. Mater. Chem. A 2015, 3, 4706-4715. [CrossRef]

318. Bhaskar, A.; Deepa, M.; Rao, T.; Varadaraju, U. Enhanced nanoscale conduction capability of a $\mathrm{MoO}_{2} /$ graphene composite for high performance anodes in lithium ion batteries. J. Power Sources 2012, 216, 169-178. [CrossRef]

319. Wang, X.; Xiao, Y.; Wang, J.; Sun, L.; Cao, M. Facile fabrication of molybdenum dioxide/nitrogen-doped graphene hybrid as high performance anode material for lithium ion batteries. J. Power Sources 2015, 274, 142-148. [CrossRef]

320. Feng, Y.; Liu, H. One-dimensional architecture with reduced graphene oxide supporting ultrathin $\mathrm{MoO}_{2}$ nanosheets as high performance anodes for lithium-ion batteries. Nanotechnology 2019, 30, 315602. [CrossRef] [PubMed]

321. Li, Y.; Luo, J.; Hu, X.; Wang, X.; Liang, J.-C.; Yu, K. Fabrication of $\mathrm{TiO}_{2}$ hollow nanostructures and their application in lithium ion batteries. J. Alloys Compd. 2015, 651, 685-689. [CrossRef]

322. Zhang, X.; Kumar, P.S.; Aravindan, V.; Liu, H.H.; Sundaramurthy, J.; Mhaisalkar, S.G.; Duong, H.M.; Ramakrishna, S.; Madhavi, S. Electrospun $\mathrm{TiO}_{2}$-graphene composite nanofibers as a highly durable insertion anode for lithium ion batteries. J. Phys. Chem. C 2012, 116, 14780-14788. [CrossRef]

323. El-Deen, S.S.; Hashem, A.M.; Ghany, A.E.A.; Indris, S.; Ehrenberg, H.; Mauger, A.; Julien, C.M. Anatase TiO 2 nanoparticles for lithium-ion batteries. Ionics 2018, 24, 2925-2934. [CrossRef]

324. Wu, F.; Wang, Z.; Li, X.; Guo, H. Simple preparation of petal-like $\mathrm{TiO}_{2}$ nanosheets as anode materials for lithium-ion batteries. Ceram. Int. 2014, 40, 16805-16810. [CrossRef]

325. Kucinskis, G.; Bajars, G.; Kleperis, J. Graphene in lithium ion battery cathode materials: A review. J. Power Sources 2013, 240, 66-79. [CrossRef]

326. Li, B.; Yuan, Z.; Xu, Y.; Liu, J. N-doped graphene as an efficient electrocatalyst for lithium-thionyl chloride batteries. Appl. Catal. A Gen. 2016, 523, 241-246. [CrossRef]

327. Zhen, M.; Zhu, X.; Zhang, X.; Zhou, Z.; Liu, L. Reduced graphene oxide-supported $\mathrm{TiO}_{2}$ fiber bundles with mesostructures as anode materials for lithium-ion batteries. Chem. A Eur. J. 2015, 21, 14454-14459. [CrossRef] [PubMed]

328. He, L.; Ma, R.; Du, N.; Ren, J.; Wong, T.; Li, Y.Y.; Lee, S.T. Growth of $\mathrm{TiO}_{2}$ nanorod arrays on reduced graphene oxide with enhanced lithium-ion storage. J. Mater. Chem. 2012, 22, 19061-19066. [CrossRef]

329. Li, J.; Huang, J.; Li, J.; Cao, L.; Qi, H.; Cheng, Y.; Xi, Q.; Dang, H. Improved Li-ion diffusion process in $\mathrm{TiO}_{2} / \mathrm{rGO}$ anode for lithium-ion battery. J. Alloys Compd. 2017, 727, 998-1005. [CrossRef]

330. Zhang, Z.; Zhang, L.; Li, W.; Yu, A.; Wu, P. Carbon-coated mesoporous $\mathrm{TiO}_{2}$ nanocrystals grown on graphene for lithium-ion batteries. ACS Appl. Mater. Interfaces 2015, 7, 10395-10400. [CrossRef] [PubMed]

331. Liu, Y.; Yang, Y. Recent progress of $\mathrm{TiO}_{2}$-based anodes for Li ion batteries. J. Nanomater. 2016, 2016 , 1-15. [CrossRef]

332. Etacheri, V.; Yourey, J.E.; Bartlett, B.M. Chemically bonded $\mathrm{TiO}_{2}-$ bronze nanosheet/reduced graphene oxide hybrid for high-power lithium-ion batteries. ACS Nano 2014, 8, 1491-1499. [CrossRef] 
333. Zhao, X.; Liu, H.; Ding, M.; Feng, Y. In-situ constructing of hollow $\mathrm{TiO}_{2} @ \mathrm{rGO}$ hybrid spheres as high-rate and long-life anode materials for lithium-ion batteries. Ceram. Int. 2019, 45, 12476-12483. [CrossRef]

334. Dong, L.; Li, M.; Zhao, M.; Feng, J.; Han, Y.; Deng, J.; Li, X.; Li, D.; Sun, X. Hydrothermal synthesis of mixed crystal phases $\mathrm{TiO}_{2}$-reduced graphene oxide nanocomposites with small particle size for lithium ion batteries. Int. J. Hydrogen Energy 2014, 39, 16116-16122. [CrossRef]

335. Yang, M.-C.; Lee, Y.-Y.; Xu, B.; Powers, K.; Meng, Y.S. $\mathrm{TiO}_{2}$ flakes as anode materials for Li-ion-batteries. J. Power Sources 2012, 207, 166-172. [CrossRef]

336. Fu, Y.-X.; Dai, Y.; Pei, X.-Y.; Lyu, S.-S.; Heng, Y.; Mo, D.-C. TiO 2 nanorods anchor on reduced graphene oxide $\left(\mathrm{R}-\mathrm{TiO}_{2} / \mathrm{rGO}\right)$ composite as anode for high performance lithium-ion batteries. Appl. Surf. Sci. 2019, 497, 143553. [CrossRef]

337. Li, D.; Shi, D.; Liu, Z.; Liu, H.K.; Guo, Z. $\mathrm{TiO}_{2}$ nanoparticles on nitrogen-doped graphene as anode material for lithium ion batteries. J. Nanopart. Res. 2013, 15, 1674. [CrossRef]

338. Geng, C.; Yu, J.; Shi, F. Synthesis and electrochemical performance of $\mathrm{TiO}_{2} / \mathrm{rGO}$ composites with different layers of graphene oxide as anode materials for lithium-ion battery. IOP Conf. Ser. Mater. Sci. Eng. 2019, 585, 012090. [CrossRef]

339. Mondal, A.; Maiti, S.; Singha, K.; Mahanty, S.; Panda, A.B. $\mathrm{TiO}_{2}-\mathrm{rGO}$ nanocomposite hollow spheres: Large scale synthesis and application as an efficient anode material for lithium-ion batteries. J. Mater. Chem. A 2017, 5, 23853-23862. [CrossRef]

340. Shen, T.; Zhou, X.; Cao, H.; Zheng, C.; Liu, Z. $\mathrm{TiO}_{2}$ (B)-CNT-graphene ternary composite anode material for lithium ion batteries. RSC Adv. 2015, 5, 22449-22454. [CrossRef]

341. Fang, Y.; Hu, R.; Liu, B.; Zhang, Y.; Zhu, K.; Yan, J.; Ye, K.; Cheng, K.; Wang, G.; Cao, D. MXene-derived $\mathrm{TiO}_{2}$ /reduced graphene oxide composite with an enhanced capacitive capacity for $\mathrm{Li}$-ion and K-ion batteries. J. Mater. Chem. A 2019, 7, 5363-5372. [CrossRef]

342. Farooq, U.; Ahmed, F.; Pervez, S.A.; Rehman, S.; Pope, M.A.; Fichtner, M.; Roberts, E.P. A stable TiO2-graphene nanocomposite anode with high rate capability for lithium-ion batteries. RSC Adv. 2020, 10, 29975-29982. [CrossRef]

343. Subaşı, Y.; Somer, M.; Yağcı, M.B.; Slabon, A.; Afyon, S. Surface modified $\mathrm{TiO}_{2} /$ reduced graphite oxide nanocomposite anodes for lithium ion batteries. J. Solid State Electrochem. 2020, 24, 1085-1093. [CrossRef]

344. Williams, G.; Seger, B.; Kamat, P.V. $\mathrm{TiO}_{2}$-graphene nanocomposites. UV-assisted photocatalytic reduction of graphene oxide. ACS Nano 2008, 2, 1487-1491. [CrossRef]

345. Qiu, J.; Zhang, P.; Ling, M.; Li, S.; Liu, P.; Zhao, H.; Zhang, S. Photocatalytic synthesis of $\mathrm{TiO}_{2}$ and reduced graphene oxide nanocomposite for lithium-ion batteries. ACS Appl. Mater. Interfaces 2012, 4, 3636-3642. [CrossRef] [PubMed]

346. Tong, X.; Zeng, M.; Li, J.; Li, F. UV-assisted synthesis of surface modified mesoporous $\mathrm{TiO}_{2} / \mathrm{G}_{\text {microspheres }}$ and its electrochemical performances in lithium ion batteries. Appl. Surf. Sci. 2017, 392, 897-903. [CrossRef]

347. Zhang, X.; Liu, Y.; Wang, X.; Li, B. Improving the anode performances of $\mathrm{TiO}_{2}$-carbon-rGO composites in lithium ion batteries by UV irradiation. New J. Chem. 2015, 39, 9345-9350. [CrossRef]

348. Ren, Y.; Zhang, J.; Liu, Y.; Li, H.; Wei, H.; Li, B.; Wang, X. Synthesis and superior anode performances of $\mathrm{TiO}_{2}$-carbon-rGO composites in lithium-ion batteries. ACS Appl. Mater. Interfaces 2012, 4, 4776-4780. [CrossRef]

349. Madhusanka, S.A. $\mathrm{TiO}_{2}$ microparticles/reduced graphene oxide composite as anode material for lithium-ion battery. Int. J. Electrochem. Sci. 2020, 15, 2792-2805. [CrossRef]

350. Bai, L.; Fang, F.; Zhao, Y.; Liu, Y.; Li, J.; Huang, G.; Sun, H. A sandwich structure of mesoporous anatase $\mathrm{TiO}_{2}$ sheets and reduced graphene oxide and its application as lithium-ion battery electrodes. RSC Adv. 2014, 4, 43039-43046. [CrossRef]

351. Park, J.; Kim, S.; Lee, G.; Choi, J. RGO-coated $\mathrm{TiO}_{2}$ microcones for high-rate lithium-ion batteries. ACS Omega 2018, 3, 10205-10210. [CrossRef]

352. Yu, W.-B.; Hu, Z.-Y.; Jin, J.; Yi, M.; Yan, M.; Li, Y.; Wang, H.-E.; Gao, H.-X.; Mai, L.-Q.; Hasan, T.; et al. Unprecedented and highly stable lithium storage capacity of (001) faceted nanosheet-constructed hierarchically porous $\mathrm{TiO}_{2} / \mathrm{rGO}$ hybrid architecture for high-performance Li-ion batteries. Natl. Sci. Rev. 2020, 7, 1046-1058. [CrossRef]

353. Liang, Y.; Xiong, X.; Xu, Z.; Xia, Q.; Wan, L.; Liu, R.; Chen, G.; Chou, S. Ultrathin 2D mesoporous TiO $2 / \mathrm{rGO}^{2}$ heterostructure for high-performance lithium storage. Small 2020, 16, 2000030. [CrossRef] 
354. Wang, J.; Shen, L.; Li, H.; Wang, X.; Nie, P.; Ding, B.; Xu, G.; Dou, H.; Zhang, X. A facile one-pot synthesis of $\mathrm{TiO}_{2} /$ nitrogen-doped reduced graphene oxide nanocomposite as anode materials for high-rate lithium-ion batteries. Electrochim. Acta 2014, 133, 209-216. [CrossRef]

355. Li, J.; Huang, J.; Li, J.; Cao, L.; Qi, H.; Cheng, Y. N-doped $\mathrm{TiO}_{2} / \mathrm{rGO}$ hybrids as superior Li-ion battery anodes with enhanced Li-ions storage capacity. J. Alloys Compd. 2019, 784, 165-172. [CrossRef]

356. Fang, R.; Miao, C.; Mou, H.; Xiao, W. Facile synthesis of $\mathrm{Si}_{\mathrm{T}} \mathrm{TiO}_{2} @ \mathrm{rGO}$ composite with sandwich-like nanostructure as superior performance anodes for lithium ion batteries. J. Alloys Compd. 2020, 818, 152884. [CrossRef]

357. Shi, Y.; Wen, L.; Li, F.; Cheng, H.-M. Nanosized $\mathrm{Li}_{4} \mathrm{Ti}_{5} \mathrm{O}_{12} /$ graphene hybrid materials with low polarization for high rate lithium ion batteries. J. Power Sources 2011, 196, 8610-8617. [CrossRef]

358. Ri, S.G.; Zhan, L.; Wang, Y.; Zhou, L.; Hu, J.; Liu, H. $\mathrm{Li}_{4} \mathrm{Ti}_{5} \mathrm{O}_{12}$ /graphene nanostructure for lithium storage with high-rate performance. Electrochim. Acta 2013, 109, 389-394. [CrossRef]

359. Shen, L.; Yuan, C.; Luo, H.; Zhang, X.; Yang, S.; Lu, X. In situ synthesis of high-loading $\mathrm{Li}_{4} \mathrm{Ti}_{5} \mathrm{O}_{12}-$ graphene hybrid nanostructures for high rate lithium ion batteries. Nanoscale 2011, 3, 572-574. [CrossRef]

360. Kim, H.-K.; Jegal, J.-P.; Kim, J.-Y.; Yoon, S.-B.; Roh, K.C.; Kim, K.-B. In situ fabrication of lithium titanium oxide by microwave-assisted alkalization for high-rate lithium-ion batteries. J. Mater. Chem. A 2013, 1, 14849. [CrossRef]

361. Chen, W.; Jiang, H.; Hu, Y.; Dai, Y.; Li, C. Mesoporous single crystals $\mathrm{Li}_{4} \mathrm{Ti}_{5} \mathrm{O}_{12}$ grown on rGO as high-rate anode materials for lithium-ion batteries. Chem. Commun. 2014, 50, 8856-8859. [CrossRef]

362. Ni, H.; Song, W.-L.; Fan, L.-Z. A strategy for scalable synthesis of Li4Ti5O12/reduced graphene oxide toward high rate lithium-ion batteries. Electrochem. Commun. 2014, 40, 1-4. [CrossRef]

363. Di, S.; Li, J.; Zhao, Y.; Hou, L.; Ma, Z.; Qin, X.; Shao, G. Hierarchical microspheres assembled from $\mathrm{Li}_{4} \mathrm{Ti}_{5} \mathrm{O}_{12}-\mathrm{TiO}_{2}$ nanosheets with advanced lithium ion storage. Ionics 2020, 26, 2763-2772. [CrossRef]

364. Chen, C.; Huang, Y.; Zhang, H.; Wang, X.; Li, G.; Wang, Y.; Jiao, L.; Yuan, H. Small amount of reduce graphene oxide modified $\mathrm{Li}_{4} \mathrm{Ti}_{5} \mathrm{O}_{12}$ nanoparticles for ultrafast high-power lithium ion battery. J. Power Sources 2015, 278, 693-702. [CrossRef]

365. Zhang, J.; Cai, Y.; Wu, J.; Yao, J. Graphene oxide-confined synthesis of $\mathrm{Li}_{4} \mathrm{Ti}_{5} \mathrm{O}_{12}$ microspheres as high-performance anodes for lithium ion batteries. Electrochim. Acta 2015, 165, 422-429. [CrossRef]

366. Jeong, J.H.; Kim, M.-S.; Kim, Y.-H.; Roh, K.C.; Kim, K.-B. High-rate $\mathrm{Li}_{4} \mathrm{Ti}_{5} \mathrm{O}_{12} / \mathrm{N}$-doped reduced graphene oxide composite using cyanamide both as nanospacer and a nitrogen doping source. J. Power Sources 2016, 336, 376-384. [CrossRef]

367. Cao, N.; Wen, L.; Song, Z.; Meng, W.; Qin, X. $\mathrm{Li}_{4} \mathrm{Ti}_{5} \mathrm{O}_{12} /$ reduced graphene oxide composite as a high-rate anode material for lithium ion batteries. Electrochim. Acta 2016, 209, 235-243. [CrossRef]

368. Ogechi, O.; Hao, T.; Osgood, H.; Zhang, B.; Chen, L.; Cui, L.; Song, X.-M.; Ogoke, O.; Wu, G. Advanced mesoporous spinel $\mathrm{Li}_{4} \mathrm{Ti}_{5} \mathrm{O}_{12} / \mathrm{rGO}$ composites with increased surface lithium storage capability for high-power lithium-ion batteries. ACS Appl. Mater. Interfaces 2016, 8, 9162-9169. [CrossRef]

369. Meng, T.; Yi, F.; Cheng, H.; Hao, J.; Shuab, D.; Zhao, S.; He, C.; Song, X.; Zhang, F. Preparation of lithium titanate/reduced graphene oxide composites with three-dimensional "fishnet-like" conductive Structure via a gas-foaming method for high-rate lithium-ion batteries. ACS Appl. Mater. Interfaces 2017, 9, 42883-42892. [CrossRef]

370. Xiao, H.; Pender, J.P.; Meece-Rayle, M.A.; De Souza, J.P.; Klavetter, K.C.; Ha, H.; Lin, J.; Heller, A.; Ellison, C.J.; Mullins, C.B. Reduced-graphene oxide/poly(acrylic acid) aerogels as a three-dimensional replacement for metal-foil current collectors in lithium-ion batteries. ACS Appl. Mater. Interfaces 2017, 9, 22641-22651. [CrossRef]

371. Pender, J.P.; Xiao, H.; Dong, Z.; Cavallaro, K.A.; Weeks, J.A.; Heller, A.; Ellison, C.J.; Mullins, C.B. Compact lithium-ion battery electrodes with lightweight reduced graphene oxide/poly(acrylic acid) current collectors. ACS Appl. Energy Mater. 2018, 2, 905-912. [CrossRef]

372. Ha, H.; Shanmuganathan, K.; Ellison, C.J. Mechanically stable thermally crosslinked poly(acrylic acid)/reduced graphene oxide aerogels. ACS Appl. Mater. Interfaces 2015, 7, 6220-6229. [CrossRef]

373. Zhang, F.; Yiab, F.; Meng, T.; Gao, A.; Shuab, D.; Chen, H.; Cheng, H.; Zhou, X. In situ supramolecular self-assembly assisted synthesis of $\mathrm{Li}_{4} \mathrm{Ti}_{5} \mathrm{O}_{12}$-carbon-reduced graphene oxide microspheres for lithium-ion batteries. ACS Sustain. Chem. Eng. 2018, 7, 916-924. [CrossRef] 
374. Chen, Y.; Zhang, H.; Li, Y.; Chen, Y.; Luo, T. Electrochemical performance of $\mathrm{Li}_{4} \mathrm{Ti}_{5} \mathrm{O}_{12} /$ carbon nanotubes/graphene composite $\mathrm{s}$ an anode material in lithium-ion batteries. Int. J. Hydrogen Energy 2017, 42, 7195-7201. [CrossRef]

375. Roh, H.-K.; Lee, G.-W.; Haghighat-Shishavan, S.; Chung, K.Y.; Kim, K.-B. Polyol-mediated carbon-coated $\mathrm{Li}_{4} \mathrm{Ti}_{5} \mathrm{O}_{12}$ nanoparticle/graphene composites with long-term cycling stability for lithium and sodium ion storages. Chem. Eng. J. 2020, 385, 123984. [CrossRef]

376. Uceda, M.; Chiu, H.-C.; Gauvin, R.; Zaghib, K.; Demopoulos, G.P. Electrophoretically co-deposited $\mathrm{Li}_{4} \mathrm{Ti}_{5} \mathrm{O}_{12} /$ reduced graphene oxide nanolayered composites for high-performance battery application. Energy Storage Mater. 2020, 26, 560-569. [CrossRef]

377. Mitra, S.; Poizot, P.; Finke, A.; Tarascon, J.-M. Growth and electrochemical characterization versus lithium of $\mathrm{Fe}_{3} \mathrm{O}_{4}$ electrodes made by electrodeposition. Adv. Funct. Mater. 2006, 16, 2281-2287. [CrossRef]

378. Zhu, S.P.; Fan, L.; Lu, Y.Y. Highly uniform $\mathrm{Fe}_{3} \mathrm{O}_{4}$ nanoparticle-rGO composites as anode materials for high performance lithium-ion batteries. RSC Adv. 2017, 7, 54939-54946. [CrossRef]

379. Su, Q.; Xie, D.; Zhang, J.; Du, G.; Xu, B. In situ transmission electron microscopy observation of the coversion mechanism of $\mathrm{Fe}_{2} \mathrm{O}_{3}$ /graphene anode during lithiation-delithiation processes. ACS Nano 2013, 7, 9115-9121. [CrossRef]

380. Shi, Y.-H.; Wang, K.; Li, H.-H.; Wang, H.-F.; Li, X.-Y.; Wu, X.-L.; Zhang, J.-P.; Xie, H.-M.; Su, Z.-M.; Wang, J.; et al. $\mathrm{Fe}_{3} \mathrm{O}_{4}$ nanoflakes-RGO composites: A high rate anode material for lithium-ion batteries. Appl. Surf. Sci. 2020, 511, 145465. [CrossRef]

381. Lian, P.; Zhu, X.; Xiang, H.; Li, Z.; Yang, W.; Wang, H. Enhanced cycling performance of $\mathrm{Fe}_{3} \mathrm{O}_{4}$-graphene nanocomposite as an anode material for lithium-ion batteries. Electrochim. Acta 2010, 56, 834-840. [CrossRef]

382. Zhu, S.-P.; Wu, T.; Su, H.-M.; Qu, S.-S.; Xie, Y.-J.; Chen, M.; Diao, G. Hydrothermal synthesis of $\mathrm{Fe}_{3} \mathrm{O}_{4} / \mathrm{rGO}$ nanocomposites as anode materials for lithium ion batteries. Acta Physico Chimica Sin. 2016, 32, 2737-2744. [CrossRef]

383. Ji, L.; Tan, Z.; Kuykendall, T.R.; Aloni, S.; Xun, S.; Lin, E.; Battaglia, V.; Zhang, $\mathrm{Y}_{\mathrm{Fe}} \mathrm{F}_{4} \mathrm{O}_{4}$ nanoparticle-integrated graphene sheets for high-performance half and full lithium ion cells. Phys. Chem. Chem. Phys. 2011, 13, 7170-7177. [CrossRef]

384. Zhu, X.; Zhu, Y.; Murali, S.; Stoller, M.D.; Ruoff, R.S. Nanostructured reduced graphene oxide $/ \mathrm{Fe}_{2} \mathrm{O}_{3}$ composite as a high-performance anode material for lithium ion batteries. ACS Nano 2011, 5, 3333-3338. [CrossRef]

385. Tan, W.K.; Asami, K.; Maegawa, K.; Kumar, R.; Kawamura, G.; Muto, H.; Matsuda, A. Fe ${ }_{3} \mathrm{O}_{4}$-embedded rGO composites as anode for rechargeable FeOx-air batteries. Mater. Today Commun. 2020, 25, 101540. [CrossRef]

386. Kumar, R.; Singh, R.K.; Vaz, A.R.; Savu, R.; Moshkalev, S.A. Self-assembled and one-step synthesis of interconnected 3D network of $\mathrm{Fe}_{3} \mathrm{O}_{4}$ /reduced graphene oxide nanosheets hybrid for high-performance supercapacitor electrode. ACS Appl. Mater. Interfaces 2017, 9, 8880-8890. [CrossRef]

387. Yang, Y.; Li, J.; Chen, D.; Zhao, J. A facile electrophoretic deposition route to the $\mathrm{Fe}_{3} \mathrm{O}_{4} / \mathrm{CNTs} / \mathrm{rGO}$ composite electrode as a binder-free anode for lithium ion battery. ACS Appl. Mater. Interfaces 2016, 8, 26730-26739. [CrossRef] [PubMed]

388. Zhao, Q.; Liu, J.; Wang, Y.; Tian, W.; Liu, J.; Zang, J.; Ning, H.; Yang, C.; Wu, M. Novel in-situ redox synthesis of $\mathrm{Fe}_{3} \mathrm{O}_{4} / \mathrm{rGO}$ composites with superior electrochemical performance for lithium-ion batteries. Electrochim. Acta 2018, 262, 233-240. [CrossRef]

389. Bhuvaneswari, S.; Pratheeksha, P.M.; Anandan, S.; Rangappa, D.; Gopalan, R.; Rao, T.N. Efficient reduced graphene oxide grafted porous $\mathrm{Fe}_{3} \mathrm{O}_{4}$ composite as a high performance anode material for Li-ion batteries. Phys. Chem. Chem. Phys. 2014, 16, 5284-5294. [CrossRef] [PubMed]

390. Liang, C.-L.; Liu, Y.; Bao, R.-Y.; Luo, Y.; Yangb, W.; Xie, B.; Yang, M.-B. Effects of $\mathrm{Fe}_{3} \mathrm{O}_{4}$ loading on the cycling performance of $\mathrm{Fe} 3 \mathrm{O} 4 / \mathrm{rGO}$ composite anode material for lithium ion batteries. J. Alloys Compd. 2016, 678, 80-86. [CrossRef]

391. Wang, H.; Kalubowilage, M.; Bossmann, S.H.; Amama, P.B. Design of highly porous $\mathrm{Fe}_{3} \mathrm{O}_{4} @$ reduced graphene oxide via a facile PMAA-induced assembly. RSC Adv. 2019, 9, 27927-27936. [CrossRef]

392. Xiao, Z.C.; Li, Y.; Liang, C.L.; Bao, R.Y.; Yang, M.B.; Yang, W. Scalable synthesis of an artificial polydopamine solid-electrolyte-interface-assisted 3D rGO/ $\mathrm{Fe}_{3} \mathrm{O}_{4} @ \mathrm{PDA}$ hydrogel for a highly stable anode with enhanced lithium-ion-storage properties. ChemElectroChem 2019, 6, 1069-1077. [CrossRef] 
393. Qi, H.; Cao, L.; Li, J.; Huang, J.; Ma, M.; Cheng, Y.; Wang, C.; Dang, H. Rice crust-like Fe $\mathrm{O}_{4} @ \mathrm{C} / \mathrm{rGO}$ with improved extrinsic pseudocapacitance for high-rate and long-life Li-ion anodes. J. Alloys Compd. 2019, 804, 57-64. [CrossRef]

394. Khan, A.J.; Javed, M.S.; Hanif, M.; Abbas, Y.; Liao, X.; Ahmed, G.; Saleem, M.; Yun, S.; Liu, Z. Facile synthesis of a novel $\mathrm{Fe}_{3} \mathrm{O}_{4}$-rGO- $\mathrm{MoO}_{3}$ ternary nano-composite for high-performance hybrid energy storage applications. Ceram. Int. 2020, 46, 3124-3131. [CrossRef]

395. Pei, M.; Wu, Y.; Qi, Z.; Mei, D. Synthesis and electrochemical performance of $\mathrm{NiO} / \mathrm{Fe}_{3} \mathrm{O}_{4} / \mathrm{rGO}$ as anode material for lithium ion battery. Ionics 2020, 26, 3831-3840. [CrossRef]

396. Xiao, Z.-C.; Li, Y.; Liang, C.-L.; Bao, R.-Y.; Yang, M.-B.; Yangb, W. Driven by electricity: Multilayered GO$\mathrm{Fe}_{3} \mathrm{O}_{4} @ P D A-P A M$ flake assembled micro flower-like anode for high-performance lithium ion batteries. Appl. Surf. Sci. 2020, 499, 143934. [CrossRef]

397. Gao, R.; Wang, S.; Xu, Z.; Li, H.; Chen, S.; Hou, H. High-performance anode materials with superior structure of $\mathrm{Fe}_{3} \mathrm{O}_{4} / \mathrm{FeS} / \mathrm{rGO}$ composite for lithium ion batteries. Nano 2020, 15, 2050128. [CrossRef]

398. Wu, Q.; Jiang, R.; Liu, H. Carbon layer encapsulated $\mathrm{Fe}_{3} \mathrm{O}_{4} @$ reduced graphene oxide lithium battery anodes with long cycle performance. Ceram. Int. 2020, 46, 12732-12739. [CrossRef]

399. Liang, Y.; $\mathrm{Lu}, \mathrm{W}$. Gamma-irradiation synthesis of $\mathrm{Fe}_{3} \mathrm{O}_{4} / \mathrm{rGO}$ nanocomposites as lithium-ion battery anodes. J. Mater. Sci. Mater. Electron. 2020, 31, 17075-17083. [CrossRef]

400. Wang, J.; Deng, Q.; Qinglin, D.; Jiang, K.; Zhang, J.; Hu, Z.; Chu, J.; Wang, J.; Deng, Q.; Qinglin, D.; et al. Copper ferrites@reduced graphene oxide anode materials for advanced lithium storage applications. Sci. Rep. 2017, 7, 1-12. [CrossRef]

401. Gao, T.; Xu, C.; Li, R.; Zhang, R.; Wang, B.; Jiang, X.; Hu, M.; Bando, Y.; Kong, D.; Dai, P.; et al. Biomass-derived carbon paper to sandwich magnetite anode for long-life Li-ion battery. ACS Nano 2019, 13, 11901-11911. [CrossRef]

402. Jiao, Y.; Zhang, H.; Dong, T.; Shen, P.; Cai, Y.; Zhang, H.; Zhang, S. Improved electrochemical performance in nanoengineered pomegranate-shaped $\mathrm{Fe}_{3} \mathrm{O}_{4} / \mathrm{RGO}$ nanohybrids anode material. J. Mater. Sci. 2016, 52, 3233-3243. [CrossRef]

403. Lee, K.K.; Deng, S.; Fan, H.M.; Mhaisalkar, S.; Tan, H.R.; Tok, E.S.; Loh, K.P.; Chin, W.S.; Sow, C.H. $\alpha-\mathrm{Fe}_{2} \mathrm{O}_{3}$ nanotubes-reduced graphene oxide composites as synergistic electrochemical capacitor materials. Nanoscale 2012, 4, 2958-2961. [CrossRef]

404. Zhang, Z.-J.; Wang, Y.-X.; Chou, S.-L.; Li, H.-J.; Liu, H.-K.; Wang, J.-Z. Rapid synthesis of $\alpha-\mathrm{Fe}_{2} \mathrm{O}_{3} / \mathrm{rGO}$ nanocomposites by microwave autoclave as superior anodes for sodium-ion batteries. J. Power Sources 2015, 280, 107-113. [CrossRef]

405. Pradhan, G.K.; Padhi, D.K.; Parida, K.M. Fabrication of $\alpha-\mathrm{Fe}_{2} \mathrm{O}_{3}$ nanorod/RGO composite: A novel hybrid photocatalyst for phenol degradation. ACS Appl. Mater. Interfaces 2013, 5, 9101-9110. [CrossRef] [PubMed]

406. Qu, J.; Yin, Y.-X.; Wang, Y.-Q.; Yan, Y.; Guo, Y.-G.; Song, W. Layer structured $\alpha-\mathrm{Fe}_{2} \mathrm{O}_{3}$ nanodisk/reduced graphene oxide composites as high-performance anode materials for lithium-ion batteries. ACS Appl. Mater. Interfaces 2013, 5, 3932-3936. [CrossRef] [PubMed]

407. Liu, X.; Chen, T.; Chu, H.; Niu, L.; Sun, Z.; Pan, L.; Sun, C.Q. $\mathrm{Fe}_{2} \mathrm{O}_{3}$-reduced graphene oxide composites synthesized via microwave-assisted method for sodium ion batteries. Electrochim. Acta 2015, 166, 12-16. [CrossRef]

408. Wang, G.; Liu, T.; Luo, Y.; Zhao, Y.; Ren, Z.; Bai, J.; Wang, H. Preparation of $\mathrm{Fe}_{2} \mathrm{O}_{3}$ /graphene composite and its electrochemical performance as an anode material for lithium ion batteries. J. Alloys Compd. 2011, 509, L216-L220. [CrossRef]

409. Wang, J.; Zhou, H.; Nanda, J.; Braun, P.V. Three-dimensionally mesostructured $\mathrm{Fe}_{2} \mathrm{O}_{3}$ electrodes with good rate performance and reduced voltage hysteresis. Chem. Mater. 2015, 27, 2803-2811. [CrossRef]

410. Liu, S.; Chen, Z.; Xie, K.; Li, Y.; Xu, J.; Zheng, C. A facile one-step hydrothermal synthesis of $\alpha-\mathrm{Fe}_{2} \mathrm{O}_{3}$ nanoplates imbedded in graphene networks with high-rate lithium storage and long cycle life. J. Mater. Chem. A 2014, 2, 13942-13948. [CrossRef]

411. Lee, K.S.; Park, S.; Lee, W.; Yoon, Y.S. Hollow nanobarrels of $\alpha-\mathrm{Fe}_{2} \mathrm{O}_{3}$ on reduced graphene oxide as high-performance anode for lithium-ion batteries. ACS Appl. Mater. Interfaces 2016, 8, 2027-2034. [CrossRef]

412. Xu, B.; Guan, X.; Zhang, L.Y.; Liu, X.; Jiao, Z.; Liu, X.; Hu, X.; Zhao, X.S. A simple route to preparing $\gamma-\mathrm{Fe}_{2} \mathrm{O}_{3} / \mathrm{RGO}$ composite electrode materials for lithium ion batteries. J. Mater. Chem. A 2018, 6, 4048-4054. [CrossRef] 
413. Liu, Z.; Fu, H.; Gao, B.; Wang, Y.; Li, K.; Sun, Y.; Yin, J.; Kan, J. In-situ synthesis of $\mathrm{Fe}_{2} \mathrm{O}_{3} / \mathrm{rGO}$ using different hydrothermal methods as anode materials for lithium-ion batteries. Rev. Adv. Mater. Sci. 2020, 59, 477-487. [CrossRef]

414. Petnikota, S.; Marka, S.; Banerjee, A.; Reddy, M.; Srikanth, V.; Chowdari, B.; Reddy, M.V. Graphenothermal reduction synthesis of 'exfoliated graphene oxide/iron (II) oxide' composite for anode application in lithium ion batteries. J. Power Sources 2015, 293, 253-263. [CrossRef]

415. Zhou, X.; Wang, F.; Zhu, Y.; Liu, Z. Graphene modified $\mathrm{LiFePO}_{4}$ cathode materials for high power lithium ion batteries. J. Mater. Chem. 2011, 21, 3353-3358. [CrossRef]

416. Qi, H.; Cao, L.; Li, J.; Huang, J.; Xu, Z.; Cheng, Y.; Kong, X.; Yanagisawa, K. High Pseudocapacitance in $\mathrm{FeOOH} / \mathrm{rGO}$ composites with superior performance for high rate anode in Li-ion battery. ACS Appl. Mater. Interfaces 2016, 8, 35253-35263. [CrossRef] [PubMed]

417. Wu, C.; Xie, Y. Promising vanadium oxide and hydroxide nanostructures: From energy storage to energy saving. Energy Environ. Sci. 2010, 3, 1191-1206. [CrossRef]

418. Murphy, D.W.; Christian, P.A.; Disalvo, F.J.; Carides, J.N.; Waszczak, J.V. Lithium Incorporation by $\mathrm{V}_{6} \mathrm{O}_{13}$ and Related Vanadium $(+4,+5)$ Oxide Cathode Materials. J. Electrochem. Soc. 1981, 128, 2053-2060. [CrossRef]

419. Dai, X.; Wan, F.; Zhang, L.; Cao, H.; Niu, Z. Freestanding graphene/ $\mathrm{VO}_{2}$ composite films for highly stable aqueous $\mathrm{Zn}$-ion batteries with superior rate performance. Energy Storage Mater. 2019, 17, 143-150. [CrossRef]

420. Yan, B.; Li, X.; Bai, Z.; Lin, L.; Chen, G.; Song, X.; Xiong, D.; Li, D.; Sun, X. Superior sodium storage of novel $\mathrm{VO}_{2}$ nano-microspheres encapsulated into crumpled reduced graphene oxide. J. Mater. Chem. A 2017, 5, 4850-4860. [CrossRef]

421. Li, S.; Wei, Z.; Tang, Y.; Qian, K.; Li, Y.; Ji, S.; Luo, H.; Gao, Y.; Jin, P. Synthesis of reduced graphene oxide carried $\mathrm{VO}_{2}$ (B) Nanorods and their application in lithium-ion batteries. Sci. Adv. Mater. 2014, 6, 1293-1297. [CrossRef]

422. He, G.; Li, L.; Manthiram, A. $\mathrm{VO}_{2} / \mathrm{rGO}$ nanorods as a potential anode for sodium- and lithium-ion batteries. J. Mater. Chem. A 2015, 3, 14750-14758. [CrossRef]

423. Nethravathi, C.; Viswanath, B.; Michael, J.; Rajamath, M. Hydrothermal synthesis of a monoclinic $\mathrm{VO}_{2}$ nanotube-graphene hybrid for use as cathode material in lithium ion batteries. Carbon 2012, 50, 4839-4846. [CrossRef]

424. Song, H.J.; Choi, M.; Kim, J.-C.; Park, S.; Lee, C.W.; Hong, S.-H.; Kim, B.-K.; Kim, D.-W. Enhanced lithium storage in reduced graphene oxide-supported M-phase vanadium(IV) dioxide nanoparticles. Sci. Rep. 2016, 6, 30202. [CrossRef]

425. Choi, S.H.; Kang, Y.C. Uniform decoration of vanadium oxide nanocrystals on reduced graphene-oxide balls by an aerosol process for lithium-ion battery cathode material. Chem. A Eur. J. 2014, 20, 6294-6299. [CrossRef] [PubMed]

426. Sun, Y.; Yang, S.-B.; Lv, L.-P.; Lieberwirth, I.; Zhang, L.-C.; Ding, C.-X.; Chen, C.-H. A composite film of reduced graphene oxide modified vanadium oxide nanoribbons as a free standing cathode material for rechargeable lithium batteries. J. Power Sources 2013, 241, 168-172. [CrossRef]

427. Xiao, Z.; Peng, Z.; Wang, H.; Tang, Y. Synthesis and electrochemical properties of $\mathrm{VO}_{2} / \mathrm{rGO}$ composite for high-performance anode materials for Li-ion batteries. J. Funct. Mater. 2017, 48, 9011-9017.

428. Shi, Y.; Chou, S.L.; Wang, J.Z.; Li, H.J.; Liu, H.K.; Wu, Y.P. In situ hydrothermal synthesis of graphene woven $\mathrm{VO}_{2}$ nanoribbons with improved cycling performance. J. Power Sources 2013, 244, 684-689. [CrossRef]

429. Cui, F.; Zhao, J.; Zhang, D.; Fang, Y.; Hu, F.; Zhu, K. $\mathrm{VO}_{2}(\mathrm{~B})$ nanobelts and reduced graphene oxides composites as cathode materials for low-cost rechargeable aqueous zinc ion batteries. Chem. Eng. J. 2020, 390, 124118. [CrossRef]

430. Zhao, H.; Pan, L.; Xing, S.; Luo, J.; Xu, J. Vanadium oxides-reduced graphene oxide composite for lithium-ion batteries and supercapacitors with improved electrochemical performance. J. Power Sources 2013, 222, $21-31$. [CrossRef]

431. Lee, M.; Wee, B.-H.; Hong, J.-D. High Performance flexible supercapacitor electrodes composed of ultralarge graphene sheets and vanadium dioxide. Adv. Energy Mater. 2015, 5, 1401890. [CrossRef]

432. Xiao, X.; Li, S.; Wei, H.; Sun, D.; Wu, Y.; Jin, G.; Wang, F.; Zou, Y. Synthesis and characterization of $\mathrm{VO}_{2}(\mathrm{~B}) /$ graphene nanocomposite for supercapacitors. J. Mater. Sci. Mater. Electron. 2015, 26, 4226-4233. [CrossRef] 
433. Zhang, J.; Chen, L.; Wang, Y.; Cai, S.; Yang, H.; Yu, H.; Shi, X.; Huang, C.; Liu, X.; Peng, Y. VO 2 (B)/graphene composite-based symmetrical supercapacitor electrode via screen printing for intelligent packaging. Nanomaterials 2018, 8, 1020. [CrossRef]

434. Sahoo, R.; Lee, T.H.; Pham, D.T.; Luu, T.H.T.; Lee, Y.H. Fast-charging high-energy battery-supercapacitor hybrid: Anodic reduced graphene oxide-vanadium(IV) oxide sheet-on-sheet heterostructure. ACS Nano 2019, 13, 10776-10786. [CrossRef]

435. Lv, W.; Yang, C.; Meng, G.; Zhao, R.; Han, A.; Wang, R.; Liu, J. VO 2 (B) nanobelts/reduced graphene oxide composites for high-performance flexible all-solid-state supercapacitors. Sci. Rep. 2019, 9, 1-8. [CrossRef] [PubMed]

436. Nethravathi, C.; Rajamathi, C.R.; Rajamathi, M.; Gautam, U.K.; Wang, X.; Golberg, D.; Bando, Y. N-Doped graphene- $\mathrm{VO}_{2}$ (B) nanosheet-built 3D flower hybrid for lithium ion battery. ACS Appl. Mater. Interfaces 2013, 5, 2708-2714. [CrossRef] [PubMed]

437. Reddy, C.S.; Ravichandran, D.; Rambabu, B.; Holze, R. Carbon and functionalized graphene oxide coated vanadium oxide electrodes for lithium ion batteries. Appl. Surf. Sci. 2014, 305, 596-602. [CrossRef]

438. Kang, M.S.; Park, S.K.; Nakhanivej, P.; Shin, K.H.; Yeon, J.S.; Park, H.S. Mesoporous $\mathrm{VO}_{2}$ (B) nanorods deposited onto graphene architectures for enhanced rate capability and cycle life of Li ion battery cathodes. J. Alloys Compd. 2020, 855, 157361. [CrossRef]

439. Song, Z.; Lu, X.; Hu, Q.; Lin, D.; Zheng, Q. Construction of reduced graphene oxide wrapped yolk-shell vanadium dioxide sphere hybrid host for high-performance lithium-sulfur batteries. Dalton Trans. 2020, 49, 14921-14930. [CrossRef] [PubMed]

440. Mahadi, N.B.; Park, J.-S.; Park, J.-H.; Chung, K.Y.; Yi, S.Y.; Sun, Y.-K.; Myung, S.-T. Vanadium dioxide-reduced graphene oxide composite as cathode materials for rechargeable Li and Na batteries. J. Power Sources 2016, 326, 522-532. [CrossRef]

441. Jiang, L.; Qu, Y.; Ren, Z.; Yu, P.; Zhao, D.; Zhou, W.; Wang, L.; Fu, H. In situ carbon-coated yolk-shell $\mathrm{V}_{2} \mathrm{O}_{3}$ microspheres for lithium-ion batteries. ACS Appl. Mater. Interfaces 2015, 7, 1595-1601. [CrossRef]

442. Song, H.J.; Choi, M.; Kim, J.-C.; Park, S.; Lee, C.W.; Hong, S.-H.; Kim, D.-W. Li-electroactivity of thermally-reduced $\mathrm{V}_{2} \mathrm{O}_{3}$ nanoparticles. Mater. Lett. 2016, 180, 243-246. [CrossRef]

443. Leng, J.; Mei, H.; Zhan, L.; Wang, Y.; Yang, S.; Song, Y. $\mathrm{V}_{2} \mathrm{O}_{3}$ nanoparticles anchored onto the reduced graphene oxide for superior lithium storage. Electrochim. Acta 2017, 231, 732-738. [CrossRef]

444. Xiao, B.; Zhang, B.; Tang, L.-B.; An, C.-S.; He, Z.-J.; Tong, H.; Yu, W.-J.; Zheng, J. V ${ }_{2} \mathrm{O}_{3} / \mathrm{rGO}$ composite as a potential anode material for lithium ion batteries. Ceram. Int. 2018, 44, 15044-15049. [CrossRef]

445. Zhang, Y.; Pan, A.; Liang, S.; Chen, T.; Tang, Y.; Tan, X. Reduced graphene oxide modified $\mathrm{V}_{2} \mathrm{O}_{3}$ with enhanced performance for lithium-ion battery. Mater. Lett. 2014, 137, 174-177. [CrossRef]

446. Liu, X.; Zhang, D.; Li, G.; Xue, C.; Ding, J.; Li, B.; Chen, D.; Li, L. In situ synthesis of $\mathrm{V}_{2} \mathrm{O}_{3}$ nanorods anchored on reduced graphene oxide as high-performance lithium ion battery anode. ChemistrySelect 2018, 3, 12108-12112. [CrossRef]

447. Ramana, C.V.; Smith, R.J.; Hussain, O.M.; Massot, M.; Julien, C.M. Surface analysis of pulsed laser-deposited $\mathrm{V}_{2} \mathrm{O}_{5}$ thin films and their lithium intercalated products studied by Raman spectroscopy. Surf. Interface Anal. 2005, 37, 406-411. [CrossRef]

448. Liu, Y.; Cao, G.; Zhang, Y.; Zhou, J.; Pan, A. Controllable preparation of $\mathrm{V}_{2} \mathrm{O}_{5}$ /graphene nanocomposites as cathode materials for lithium-ion batteries. Nanoscale Res. Lett. 2016, 11, 549. [CrossRef]

449. Pandey, G.P.; Liu, T.; Brown, E.; Yang, Y.; Li, Y.; Sun, X.S.; Fang, Y.; Li, J.; Brown, J.E. Mesoporous hybrids of reduced graphene oxide and vanadium pentoxide for enhanced performance in lithium-ion batteries and electrochemical capacitors. ACS Appl. Mater. Interfaces 2016, 8, 9200-9210. [CrossRef]

450. Luo, W.; Zheng, B. Improved electrochemical performance of $\mathrm{LiNi}_{0.5} \mathrm{Co}_{0.2} \mathrm{Mn}_{0.3} \mathrm{O}_{2}$ cathode material by double-layer coating with graphene oxide and $\mathrm{V}_{2} \mathrm{O}_{5}$ for lithium-ion batteries. Appl. Surf. Sci. 2017, 404, 310-317. [CrossRef]

451. Liu, Q.; Li, Z.-F.; Liu, Y.; Zhang, H.; Ren, Y.; Sun, C.-J.; Lu, W.; Zhou, Y.; Stanciu, L.; Stach, E.A.; et al. Graphene-modified nanostructured vanadium pentoxide hybrids with extraordinary electrochemical performance for Li-ion batteries. Nat. Commun. 2015, 6, 6127. [CrossRef]

452. Cheng, J.; Wang, B.; Xin, H.L.; Yang, G.; Cai, H.-Q.; Nie, F.; Huang, H. Self-assembled $\mathrm{V}_{2} \mathrm{O}_{5}$ nanosheets/reduced graphene oxide hierarchical nanocomposite as a high-performance cathode material for lithium ion batteries. J. Mater. Chem. A 2013, 1, 10814-10820. [CrossRef] 
453. Rui, X.; Zhu, J.; Sim, D.; Xu, C.; Zeng, Y.; Hng, H.H.; Lim, T.M.; Yan, Q. Reduced graphene oxide supported highly porous $\mathrm{V}_{2} \mathrm{O}_{5}$ spheres as a high-power cathode material for lithium ion batteries. Nanoscale 2011, 3, 4752-4758. [CrossRef]

454. Hu, B.; Xiang, Q.; Cen, Y.; Li, S.; Liu, L.; Yu, D.; Chen, C. In situ constructing flexible $\mathrm{V}_{2} \mathrm{O}_{5} @ G O$ composite thin film electrode for superior electrochemical energy storage. J. Electrochem. Soc. 2018, 165, A3738-A3747. [CrossRef]

455. Pham-Cong, D.; Ahn, K.; Hong, S.W.; Jeong, S.; Kim, D.-H.; Doh, C.; Jin, J.; Jeong, E.; Cho, C.R. Cathodic performance of $\mathrm{V}_{2} \mathrm{O}_{5}$ nanowires and reduced graphene oxide composites for lithium ion batteries. Curr. Appl. Phys. 2014, 14, 215-221. [CrossRef]

456. Kurc, B.; Wysokowski, M.; Rymaniak, L.; Lijewski, P.; Piasecki, A.; Fuc, P. The Impact of the vanadium oxide addition on the physicochemical performance stability and intercalation of lithium ions of the $\mathrm{TiO}_{2}$-rGO-electrode in lithium ion batteries. Materials 2020, 13, 1018. [CrossRef] [PubMed]

457. Chen, D.; Quan, H.; Luo, S.; Luo, X.; Luoab, X.; Jiang, H. Reduced graphene oxide enwrapped vanadium pentoxide nanorods as cathode materials for lithium-ion batteries. Phys. E Low-Dimens. Syst. Nanostruct. 2014, 56, 231-237. [CrossRef]

458. Yan, B.; Li, X.; Bai, Z.; Zhao, Y.; Dong, L.; Song, X.; Li, D.; Langford, C.; Sun, X. Crumpled reduced graphene oxide conformally encapsulated hollow $\mathrm{V}_{2} \mathrm{O}_{5}$ nano/microsphere achieving brilliant lithium storage performance. Nano Energy 2016, 24, 32-44. [CrossRef]

459. Wang, S.; Zhu, K.; Yang, L.; Li, H.; Wang, S.; Tang, S.; Zhang, M.; Abliz, A.; Zhao, F. Synthesis and study of $\mathrm{V}_{2} \mathrm{O}_{5} / \mathrm{rGO}$ nanocomposite as a cathode material for aqueous zinc ion battery. Ionics 2020, 26, 1-9. [CrossRef]

460. Du, X.; Huang, G.; Qin, Y.-L.; Wang, L. Solvothermal synthesis of $\mathrm{GO} / \mathrm{V}_{2} \mathrm{O}_{5}$ composites as a cathode material for rechargeable magnesium batteries. RSC Adv. 2015, 5, 76352-76355. [CrossRef]

461. Xu, J.; Li, Z.; Zhang, X.; Huang, S.; Jiang, S.; Zhu, Q.; Sun, H.; Zakharova, G.S. Self-assembled $V_{3} \mathrm{O}_{7} /$ graphene oxide nanocomposites as cathode material for lithium-ion batteries. Int. J. Nanotechnol. 2014, 11, 808. [CrossRef]

462. Ramadoss, A.; Saravanakumar, B.; Kim, S.-J. Vanadium pentoxide/reduced graphene oxide composite as an efficient electrode material for high-performance supercapacitors and self-powered systems. Energy Technol. 2015, 3, 913-924. [CrossRef]

463. Zhang, H.; Xie, A.; Wang, C.; Wang, H.; Shen, Y.; Tian, X. Bifunctional reduced graphene oxide/ $/ \mathrm{V}_{2} \mathrm{O}_{5}$ composite hydrogel: Fabrication, high performance as electromagnetic wave absorbent and supercapacitor. ChemPhysChem 2013, 15, 366-373. [CrossRef]

464. Foo, C.Y.; Sumboja, A.; Tan, D.J.H.; Wang, J.; Lee, P.S. Flexible and highly scalable $\mathrm{V}_{2} \mathrm{O}_{5}-\mathrm{rGO}$ electrodes in an organic electrolyte for supercapacitor devices. Adv. Energy Mater. 2014, 4, 1400236. [CrossRef]

465. Zhang, Y.; Wang, Y.; Xiong, Z.; Hu, Y.; Song, W.; Huang, Q.-A.; Cheng, X.; Chen, L.-Q.; Sun, C.; Gu, H. V $2 \mathrm{O}_{5}$ nanowire composite paper as a high-performance lithium-ion battery cathode. ACS Omega 2017, 2, 793-799. [CrossRef] [PubMed]

466. Li, M.; Sun, G.; Yin, P.; Ruan, C.; Ai, K. Controlling the formation of rodlike $\mathrm{V}_{2} \mathrm{O}_{5}$ nanocrystals on reduced graphene oxide for high-performance supercapacitors. ACS Appl. Mater. Interfaces 2013, 5, 11462-11470. [CrossRef] [PubMed]

467. Deng, L.; Zhang, G.; Kang, L.; Lei, Z.; Liu, C.; Liu, Z. Graphene/ $\mathrm{VO}_{2}$ hybrid material for high performance electrochemical capacitor. Electrochim. Acta 2013, 112, 448-457. [CrossRef]

468. Fu, M.; Ge, C.; Hou, Z.; Cao, J.; He, B.; Zeng, F.; Kuang, Y. Graphene/vanadium oxide nanotubes composite as electrode material for electrochemical capacitors. Phys. B Condens. Matter 2013, 421, 77-82. [CrossRef]

469. Wang, H.; Yi, H.; Chen, X.; Wang, X. One-step strategy to three-dimensional graphene/ $\mathrm{VO}_{2}$ nanobelt composite hydrogels for high performance supercapacitors. J. Mater. Chem. A 2014, 2, 1165-1173. [CrossRef]

470. Perera, S.D.; Liyanage, A.D.; Nijem, N.; Ferraris, J.P.; Chabal, Y.J.; Balkus, J.K.J. Vanadium oxide nanowire-Graphene binder free nanocomposite paper electrodes for supercapacitors: A facile green approach. J. Power Sources 2013, 230, 130-137. [CrossRef]

471. Li, H.; Wei, J.; Qian, Y.; Zhang, J.; Yu, J.; Wang, G.; Xu, G. Effects of the graphene content and the treatment temperature on the supercapacitive properties of $\mathrm{VO}_{\mathrm{x}} /$ graphene nanocomposites. Colloids Surf. A Physicochem. Eng. Asp. 2014, 449, 148-156. [CrossRef] 
472. Saravanakumar, B.; Purushothaman, K.K.; Muralidharan, G. Fabrication of two-dimensional reduced graphene oxide supported $\mathrm{V}_{2} \mathrm{O}_{5}$ networks and their application in supercapacitors. Mater. Chem. Phys. 2016, 170, 266-275. [CrossRef]

473. Govindarajan, D.; Shankar, V.U.; Gopalakrishnan, R. Supercapacitor behavior and characterization of RGO anchored $\mathrm{V}_{2} \mathrm{O}_{5}$ nanorods. J. Mater. Sci. Mater. Electron. 2019, 30, 16142-16155. [CrossRef]

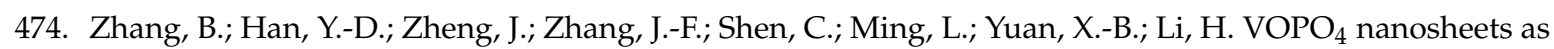
anode materials for lithium-ion batteries. Chem. Commun. 2014, 50, 11132-11134. [CrossRef]

475. He, Y.; Yang, X.; Bai, Y.; Zhang, J.; Kang, L.; Lei, Z.; Liu, Z. Vanadyl phosphate/reduced graphene oxide nanosheet hybrid material and its capacitance. Electrochim. Acta 2015, 178, 312-320. [CrossRef]

476. Lu, W.; Cong, L.; Liu, Y.; Liu, J.; Mauger, A.; Julien, C.M.; Sun, L.; Xie, H. Pseudocapacitance controlled fast-charging and long-life lithium ion battery achieved via a 3D mutually embedded $\mathrm{VPO}_{4} / \mathrm{rGO}$ electrode. J. Alloys Compd. 2020, 812, 152135. [CrossRef]

477. Yao, Z.; Kim, S.; Aykol, M.; Li, Q.; Wu, J.; He, J.; Wolverton, C. Revealing the conversion mechanism of transition metal oxide electrodes during lithiation from first-principles. Chem. Mater. 2017, 29, 9011-9022. [CrossRef]

478. Kumar, N.; Huang, C.-W.; Yen, P.-J.; Wu, W.-W.; Wei, K.-H.; Tseng, T.Y. Probing the electrochemical properties of an electrophoretically deposited $\mathrm{Co}_{3} \mathrm{O}_{4} / \mathrm{rGO} / \mathrm{CNTs}$ nanocomposite for supercapacitor applications. RSC Adv. 2016, 6, 60578-60586. [CrossRef]

479. Bankole, O.M.; Olaseni, S.E.; Adeyemo, M.A.; Ogunlaja, A.S. Microwave-assisted synthesis of cobalt oxide/reduced graphene oxide $\left(\mathrm{Co}_{3} \mathrm{O}_{4}-\mathrm{rGo}\right)$ composite and its sulfite enhanced photocatalytic degradation of organic Dyes. Z. Phys. Chem. 2020, 234, 1681-1708. [CrossRef]

480. Chen, S.Q.; Wang, Y. Microwave-assisted synthesis of $\mathrm{a} \mathrm{Co}_{3} \mathrm{O}_{4}$-graphene sheet-on-sheet nanocomposite as a superior anode material for Li-ion batteries. J. Mater. Chem. 2010, 20, 9735-9739. [CrossRef]

481. Yang, X.; Fan, K.; Zhu, Y.; Shen, J.; Jiang, X.; Zhao, P.; Li, C. Tailored graphene-encapsulated mesoporous $\mathrm{Co}_{3} \mathrm{O}_{4}$ composite microspheres for high-performance lithium ion batteries. J. Mater. Chem. 2012, 22, 17278-17283. [CrossRef]

482. Wu, Z.-S.; Ren, W.; Wen, L.; Gao, L.; Zhao, J.; Chen, Z.; Zhou, G.; Li, F.; Cheng, H.-M. Graphene anchored with $\mathrm{Co}_{3} \mathrm{O}_{4}$ nanoparticles as anode of lithium ion batteries with enhanced reversible capacity and cyclic performance. ACS Nano 2010, 4, 3187-3194. [CrossRef]

483. Zhang, W.; Zeng, Y.; Xiao, N.; Hng, H.H.; Yan, Q. One-step electrochemical preparation of graphene-based heterostructures for Li storage. J. Mater. Chem. 2012, 22, 8455-8461. [CrossRef]

484. Pan, L.; Zhao, H.; Shen, W.; Dong, X.; Xu, J. Surfactant-assisted synthesis of a $\mathrm{Co}_{3} \mathrm{O}_{4} /$ reduced graphene oxide composite as a superior anode material for Li-ion batteries. J. Mater. Chem. A 2013, 1, 7159-7166. [CrossRef]

485. Lou, Y.; Liang, J.; Peng, Y.; Chen, J. Ultra-small $\mathrm{Co}_{3} \mathrm{O}_{4}$ nanoparticles-reduced graphene oxide nanocomposite as superior anodes for lithium-ion batteries. Phys. Chem. Chem. Phys. 2015, 17, 8885-8893. [CrossRef] [PubMed]

486. Cho, S.-H.; Jung, J.-W.; Kim, C.; Kim, I.-D. Rational design of 1-D $\mathrm{Co}_{3} \mathrm{O}_{4}$ nanofibers@low content graphene composite anode for high performance Li-ion batteries. Sci. Rep. 2017, 7, srep45105. [CrossRef] [PubMed]

487. Kesavan, T.; Gunawardhana, N.; Senthil, C.; Kundu, M.; Maduraiveeran, G.; Yoshio, M.; Sasidharan, M. Fabrication of hollow $\mathrm{Co}_{3} \mathrm{O}_{4}$ nanospheres and their nanocomposites of $\mathrm{CNT}$ and $\mathrm{rGO}$ as high-performance anodes for lithium-ion batteries. ChemistrySelect 2018, 3, 5502-5511. [CrossRef]

488. Park, S.-H.; Kim, H.-K.; Roh, K.C.; Kim, K.-B. $\mathrm{Co}_{3} \mathrm{O}_{4}$-reduced graphene oxide nanocomposite synthesized by microwave-assisted hydrothermal process for Li-ion batteries. Electron. Mater. Lett. 2015, 11, 282-287. [CrossRef]

489. Zhang, K.; Lee, T.H.; Cha, J.H.; Jang, H.W.; Choi, J.-W.; Mahmoudi, M.; Shokouhimehr, M. Metal-organic framework-derived metal oxide nanoparticles@reduced graphene oxide composites as cathode materialf for rechargeable aluminum-ion batteries. Sci. Rep. 2019, 9, 13739. [CrossRef]

490. Mussa, Y.; Ahmed, F.; Arsalan, M.; Alsharaeh, E.H. Two dimensional (2D) reduced graphene oxide (RGO)/hexagonal boron nitride (h-BN) based nanocomposites as anodes for high temperature rechargeable lithium-ion batteries. Sci. Rep. 2020, 10, 1882. [CrossRef]

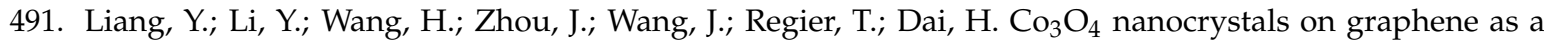
synergistic catalyst for oxygen reduction reaction. Nat. Mater. 2011, 10, 780-786. [CrossRef] 
492. Li, D.; Shi, D.; Chen, Z.; Liu, H.K.; Jia, D.; Guo, Z. Enhanced rate performance of cobalt oxide/nitrogen doped graphene composite for lithium ion batteries. RSC Adv. 2013, 3, 5003-5008. [CrossRef]

493. Lee, J.S.; Jo, M.S.; Saroha, R.; Jung, D.S.; Seon, Y.H.; Lee, J.S.; Kang, Y.C.; Kang, D.-W.; Cho, J.S. Hierarchically well-developed porous graphene nanofibers comprising N-doped graphitic C-coated cobalt oxide hollow nanospheres as anodes for high-rate Li-ion batteries. Small 2020, 16, 2002213. [CrossRef]

494. Park, G.D.; Cho, J.S.; Kang, Y.C. Novel cobalt oxide-nanobubble-decorated reduced graphene oxide sphere with superior electrochemical properties prepared by nanoscale Kirkendall diffusion process. Nano Energy 2015, 17, 17-26. [CrossRef]

495. Sun, Y.; Hu, X.; Luo, W.; Huang, Y. Ultrathin CoO/graphene hybrid nanosheets: A highly stable anode material for lithium-ion batteries. J. Phys. Chem. C 2012, 116, 20794-20799. [CrossRef]

496. Fu, G.; Chang, K.; Shangguan, E.; Tang, H.; Li, B.; Chang, Z.; Yuan, X.-Z.; Wang, H. Synthesis of CoO/reduced graphene oxide composite as an alternative additive for the nickel electrode in alkaline secondary batteries. Electrochim. Acta 2015, 180, 373-381. [CrossRef]

497. Bindumadhavan, K.; Yeh, M.-H.; Chou, T.-C.; Chang, P.-Y.; Andoongc, R.-. Ultrafine CoO Embedded reduced graphene oxide nanocomposites: A high rate anode for Li-ion battery. ChemistrySelect 2016, 1, 5758-5767. [CrossRef]

498. Bindumadhavan, K.; Chang, P.-Y.; Yeh, M.-H.; Andoongc, R.-. Ultra-small CoO nanocrystals anchored on reduced graphene oxide for enhanced lithium storage in lithium ion batteries. MRS Commun. 2017, 7, 236-244. [CrossRef]

499. Wang, L.; Zhao, D.; Liu, X.; Yu, P.; Fu, H. Hydrothermal for synthesis of CoO nanoparticles/graphene composite as Li-ion battery anodes. Acta Chim. Sin. 2017, 75, 231. [CrossRef]

500. Sun, L.; Deng, Q.; Li, Y.; Mi, H.; Wang, S.; Deng, L.; Ren, X.; Zhang, P. CoO-Co ${ }_{3} \mathrm{O}_{4}$ heterostructure nanoribbon/RGO sandwich-like composites as anode materials for high performance lithium-ion batteries. Electrochim. Acta 2017, 241, 252-260. [CrossRef]

501. Cao, L.; Kang, Q.; Li, J.; Huang, J.; Cheng, Y. Assembly control of CoO/reduced graphene oxide composites for their enhanced lithium storage behavior. Appl. Surf. Sci. 2018, 455, 96-105. [CrossRef]

502. Leng, X.; Ding, X.; Hu, J.; Wei, S.; Jiang, Z.; Lian, J.; Wang, G.; Jiang, Q.; Liu, J. In situ prepared reduced graphene oxide/CoO nanowires mutually-supporting porous structure with enhanced lithium storage performance. Electrochim. Acta 2016, 190, 276-284. [CrossRef]

503. Yin, J.; Sun, P.; Qu, G.; Xiang, G.; Hou, P.; Xu, X. A new $\mathrm{CoO} / \mathrm{Co}_{2} \mathrm{~B} / \mathrm{rGO}$ nanocomposite anode with large capacitivecontribution for high-efficiency and durable lithium storage. Appl. Surf. Sci. 2020, 508, 144698. [CrossRef]

504. Guan, X.; Nai, J.; Zhang, Y.; Wang, P.; Yang, J.; Zheng, L.; Zhang, J.; Guo, L. CoO hollow cube/reduced graphene oxide composites with enhanced lithium storage capability. Chem. Mater. 2014, 26, 5958-5964. [CrossRef]

505. Zhu, W.; Huang, H.; Gan, Y.; Tao, X.; Xia, Y.; Zhang, W. Mesoporous cobalt monoxide nanorods grown on reduced graphene oxide nanosheets with high lithium storage performance. Electrochim. Acta 2014, 138, 376-382. [CrossRef]

506. Zhang, M.; Wang, Y.; Jia, M. Three-dimensional reduced graphene oxides hydrogel anchored with ultrafine $\mathrm{CoO}$ nanoparticles as anode for lithium ion batteries. Electrochim. Acta 2014, 129, 425-432. [CrossRef]

507. Zhang, M.; Jia, M.; Jin, Y.; Shi, X. Synthesis and electrochemical performance of CoO/graphene nanocomposite as anode for lithium ion batteries. Appl. Surf. Sci. 2012, 263, 573-578. [CrossRef]

508. Zhang, H.; Wang, Y.-F.; Liu, W.-L.; Kong, F.; Ren, M.; Wang, S.-J.; Wang, X.-Q.; Duan, X.-L.; Peng, D. Designed synthesis of $\mathrm{CoO} / \mathrm{CuO} / \mathrm{rGO}$ ternary nanocomposites as high-performance anodes for lithium-ion batteries. JOM 2018, 70, 1793-1799. [CrossRef]

509. Song, Z.; Liu, W.; Sun, N.; Wei, W.; Zhang, Z.; Liu, H.; Liu, G.; Zhao, Z. One-step self-assembly fabrication of three-dimensional copper oxide/graphene oxide aerogel composite material for supercapacitors. Solid State Commun. 2019, 287, 27-30. [CrossRef]

510. Liu, Y.; Cai, X.; Shi, W. Free-standing graphene/carbon nanotubes/CuO aerogel paper anode for lithium ion batteries. Mater. Lett. 2016, 172, 72-75. [CrossRef]

511. Zhu, S.; Wu, M.; Ge, M.-H.; Zhang, H.; Lia, S.; Li, C.-H. Design and construction of three-dimensional $\mathrm{CuO} /$ polyaniline/rGO ternary hierarchical architectures for high performance supercapacitors. J. Power Sources 2016, 306, 593-601. [CrossRef] 
512. Zhao, Y.; Song, X.; Song, Q.; Yin, Z. A facile route to the synthesis copper oxide/reduced graphene oxide nanocomposites and electrochemical detection of catechol organic pollutant. CrystEngComm 2012, 14, 6710-6719. [CrossRef]

513. Zhu, J.; Zeng, G.; Nie, F.; Xu, X.; Chen, S.; Han, Q.; Wang, X. Decorating graphene oxide with CuO nanoparticles in a water-isopropanol system. Nanoscale 2010, 2, 988-994. [CrossRef]

514. Rai, A.K.; Anh, L.T.; Gim, J.; Mathew, V.; Kang, J.; Paul, B.J.; Singh, N.K.; Song, J.; Kim, J. Facile approach to synthesize $\mathrm{CuO} /$ reduced graphene oxide nanocomposite as anode materials for lithium-ion battery. J. Power Sources 2013, 244, 435-441. [CrossRef]

515. Xu, Y.-T.; Guo, Y.; Li, C.; Zhou, X.-Y.; Tucker, M.C.; Chen, J.; Sun, R.; Wong, C.-P. Graphene oxide nano-sheets wrapped $\mathrm{Cu}_{2} \mathrm{O}$ microspheres as improved performance anode materials for lithium ion batteries. Nano Energy 2015, 11, 38-47. [CrossRef]

516. Sun, L.; Deng, Q.; Li, Y.; Deng, L.; Wang, Y.; Ren, X.; Zhang, P. Solvothermal synthesis of ternary $\mathrm{Cu}_{2} \mathrm{O}-\mathrm{CuO}-\mathrm{RGO}$ composites as anode materials for high performance lithium-ion batteries. Electrochim. Acta 2016, 222, 1650-1659. [CrossRef]

517. Sheikhzadeh, M.; Sanjabi, S.; Gorji, M.; Khabazian, S. Nano composite foam layer of CuO/graphene oxide (GO) for high performance supercapacitor. Synth. Met. 2018, 244, 10-14. [CrossRef]

518. Mirzaiey, V.; Dehghanian, C.; Bokati, K.S. One-step electrodeposition of reduced graphene oxide on three-dimensional porous nano nickel-copper foam electrode and its use in supercapacitor. J. Electroanal. Chem. 2018, 813, 152-162. [CrossRef]

519. Li, X.; Fan, L.; Li, X.; Shan, H.; Chen, C.; Yan, B.; Xiong, D.; Li, D. Enhanced anode performance of flower-like $\mathrm{NiO} / \mathrm{RGO}$ nanocomposites for lithium-ion batteries. Mater. Chem. Phys. 2018, 217, 547-552. [CrossRef]

520. Liu, A.; Zhang, H.; Wang, G.; Zhang, J.; Zhang, S. Sandwich-like NiO/rGO nanoarchitectures for 4 V solid-state asymmetric-supercapacitors with high energy density. Electrochim. Acta 2018, 283, 1401-1410. [CrossRef]

521. Tian, S. Preparation of RGO/NiO Anode for Lithium-ion Batteries. Int. J. Electrochem. Sci. 2019, 14, 9459-9467. [CrossRef]

522. Ma, L.; Pei, X.-Y.; Mo, D.-C.; Heng, Y.; Lyu, S.-S.; Fu, Y.-X. Facile fabrication of NiO flakes and reduced graphene oxide (NiO/RGO) composite as anode material for lithium-ion batteries. J. Mater. Sci. Mater. Electron. 2019, 30, 5874-5880. [CrossRef]

523. Ma, L.; Lyu, S.-S.; Dai, Y.; Pei, X.-Y.; Mo, D.-C.; Fu, Y.-X. Lithium storage properties of NiO/reduced graphene oxide composites derived from different oxidation degrees of graphite oxide. J. Alloys Compd. 2019, 810, 151954. [CrossRef]

524. Li, Q.; Wei, Q.; Xie, L.; Chen, C.; Lu, C.; Su, F.; Zhou, P. Layered NiO/reduced graphene oxide composites by heterogeneous assembly with enhanced performance as high-performance asymmetric supercapacitor cathode. RSC Adv. 2016, 6, 46548-46557. [CrossRef]

525. Ren, Y.; Wang, J.; Ding, J. The synthesis and lithium storage performance of NiO/rGO/PPy anode materials. J. Changzhou Univ. (Nat. Sci.) 2015, 27, 18-23.

526. Ma, L.; Pei, X.-Y.; Mo, D.-C.; Lyu, S.-S.; Fu, Y.-X. Fabrication of NiO-ZnO/rGO composite as an anode material for lithium-ion batteries. Ceram. Int. 2018, 44, 22664-22670. [CrossRef]

527. Park, G.D.; Cho, J.S.; Kang, Y.C. Multiphase and double-layer $\mathrm{NiFe}_{2} \mathrm{O}_{4} @ \mathrm{NiO}-$ hollow-nanosphere-decorated reduced graphene oxide composite powders prepared by spray pyrolysis applying nanoscale Kirkendall diffusion. ACS Appl. Mater. Interfaces 2015, 7, 16842-16849. [CrossRef] [PubMed]

528. Li, C.; Wang, X.; Li, S.; Li, Q.; Xu, J.; Liu, X.; Liu, C.; Xu, Y.; Liu, J.; Li, H.; et al. Optimization of $\mathrm{NiFe}_{2} \mathrm{O}_{4} / \mathrm{rGO}$ composite electrode for lithium-ion batteries. Appl. Surf. Sci. 2017, 416, 308-317. [CrossRef]

529. Jo, M.S.; Lee, J.S.; Jeong, S.Y.; Kim, J.K.; Kang, Y.C.; Kang, D.-W.; Jeong, S.M.; Cho, J.S. Golden bristlegrass-like hierarchical graphene nanofibers entangled with $\mathrm{N}$-doped CNTs containing $\mathrm{CoSe}_{2}$ nanocrystals at each node for high-performance anodes in sodium-ion batteries. Small 2020, 16, 2003391. [CrossRef] [PubMed]

530. Cho, J.S.; Park, S.-K.; Jeon, K.M.; Piao, Y.; Cho, J.S. Mesoporous reduced graphene oxide/WSe ${ }_{2}$ composite particles for efficient sodium-ion batteries and hydrogen evolution reactions. Appl. Surf. Sci. 2018, 459, 309-317. [CrossRef]

531. Cho, J.S.; Lee, S.Y.; Lee, J.-K.; Kang, Y.C. Iron telluride-decorated reduced graphene oxide hybrid microspheres as anode materials with improved Na-ion storage properties. ACS Appl. Mater. Interfaces 2016, 8, 21343-21349. [CrossRef] 
532. Cho, J.S.; Lee, S.Y.; Kang, Y.C. First introduction of $\mathrm{NiSe}_{2}$ to anode material for sodium-ion batteries: A hybrid of graphene-wrapped $\mathrm{NiSe}_{2} / \mathrm{C}$ porous nanofiber. Sci. Rep. 2016, 6, 23338. [CrossRef]

533. Cho, J.S.; Lee, J.-K.; Kang, Y.C. Graphitic carbon-coated FeSe 2 hollow nanosphere-decorated reduced graphene oxide hybrid nanofibers as an efficient anode material for sodium ion batteries. Sci. Rep. 2016, 6, 23699. [CrossRef]

534. Park, G.D.; Cho, J.S.; Lee, J.-K.; Kang, Y. Na-ion storage performances of $\mathrm{FeSe}_{\mathrm{x}}$ and $\mathrm{Fe}_{2} \mathrm{O}_{3}$ hollow nanoparticles-decorated reduced graphene oxide balls prepared by nanoscale Kirkendall diffusion Process. Sci. Rep. 2016, 6, 22432. [CrossRef]

535. Mohan, V.B.; Lau, K.-T.; Hui, D.; Bhattacharyya, D. Graphene-based materials and their composites: A review on production, applications and product limitations. Compos. Part B Eng. 2018, 142, 200-220. [CrossRef]

536. Gadgil, B.; Damlin, P.; Kvarnström, C. Graphene vs. reduced graphene oxide: A comparative study of graphene-based nanoplatforms on electrochromic switching kinetics. Carbon 2016, 96, 377-381. [CrossRef]

Publisher's Note: MDPI stays neutral with regard to jurisdictional claims in published maps and institutional affiliations.

(C) 2020 by the authors. Licensee MDPI, Basel, Switzerland. This article is an open access article distributed under the terms and conditions of the Creative Commons Attribution (CC BY) license (http://creativecommons.org/licenses/by/4.0/). 